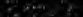


From the collection of the

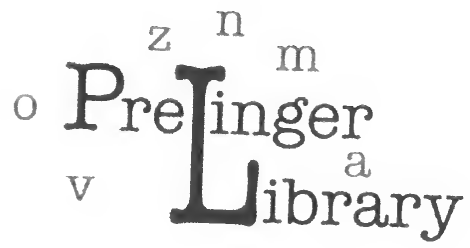

t

p

San Francisco, California 2006 
Willian I Dolan S.

$$
6 \text { Top'.s } \begin{array}{r}
\text { ek } \\
8196 \\
4303
\end{array}
$$





\section{LAND PLANNING IN THE UNITED STATES FOR CITY, STATE AND NATION}

\section{LAND ECONOMICS SERIES}

Edited by RICHARD T. ELY, LL.D.

Director of the Institute for Research in Land Economics and Public Utilities, Professor of Economics in Northwestern University.
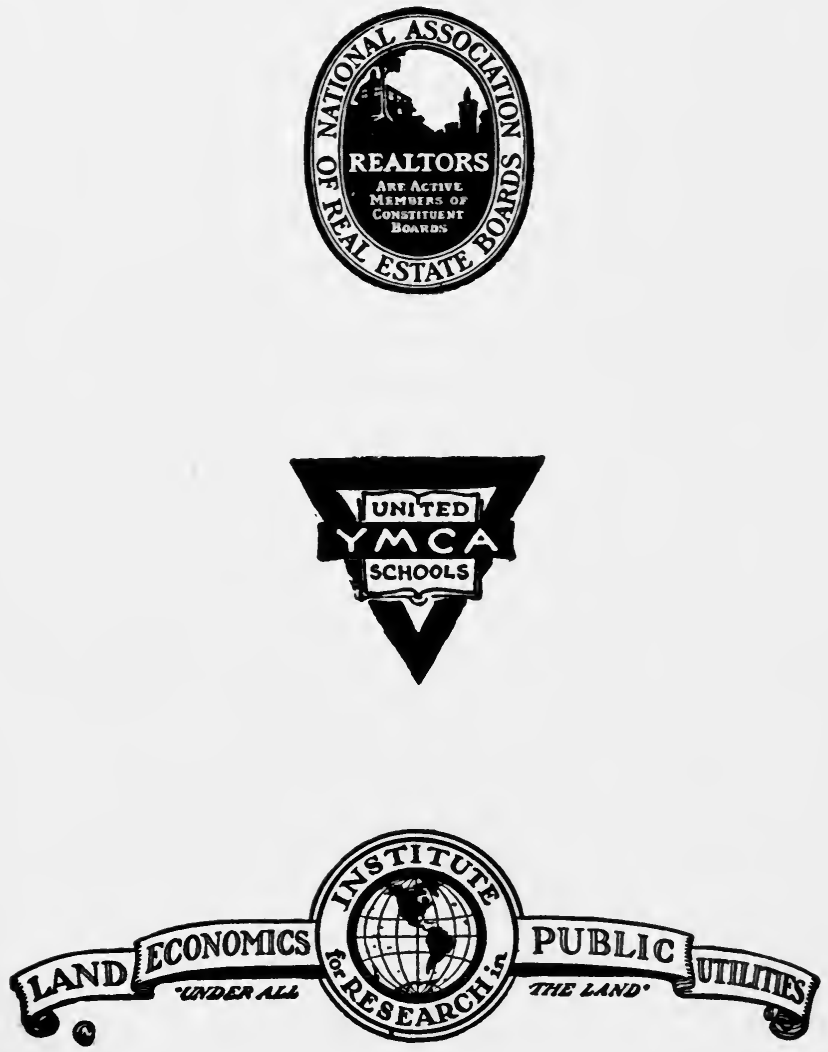


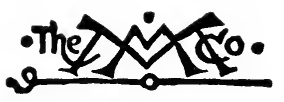

THE MACMILLAN COMPANY

NEW YORK - BOSTON - CHICAGO - DALLAS ATLANTA - SAN FRANCISCO

MACMILLAN \& CO., LIMITED

LONDON - BOMBAY - CALCUTTA

MELBOURNE

THE MACMILLAN CO. OF CANADA, LT.

TORONTO 


\title{
LAND PLANNING IN THE UNITED STATES FOR CITY, STATE AND NATION
}

\author{
VOLUME IX in the \\ STANDARD COURSE IN \\ REAL ESTATE \\ Outlined by the \\ JOINT COMMISSION \\ Representing \\ The National Association of Real Estate Boards, \\ The United Y. M. C. A. Schools \\ and \\ The Institute for Research in Land Economics and \\ Public Utilities
}




\section{LAND ECONOMICS SERIES}

The Law of City Planning and Zoning by Williams

*Principles of Real Estate Practice by Fisher

*Elements of LANd Economics by ElyMorehouse

*The Appraisal of Real Estate by Babcock

A History of Public Land Policies by Hibbard

*Elements of the Modern Building and LOAN Associations by Clark-Chase

*Real Estate Advertising by Gifford

*The Administration of Real Estate BOARDS by Nelson

*Land Planning in the United States for City, State and Nation by James

*Books that have been approved for Standard Real Estate Course. 



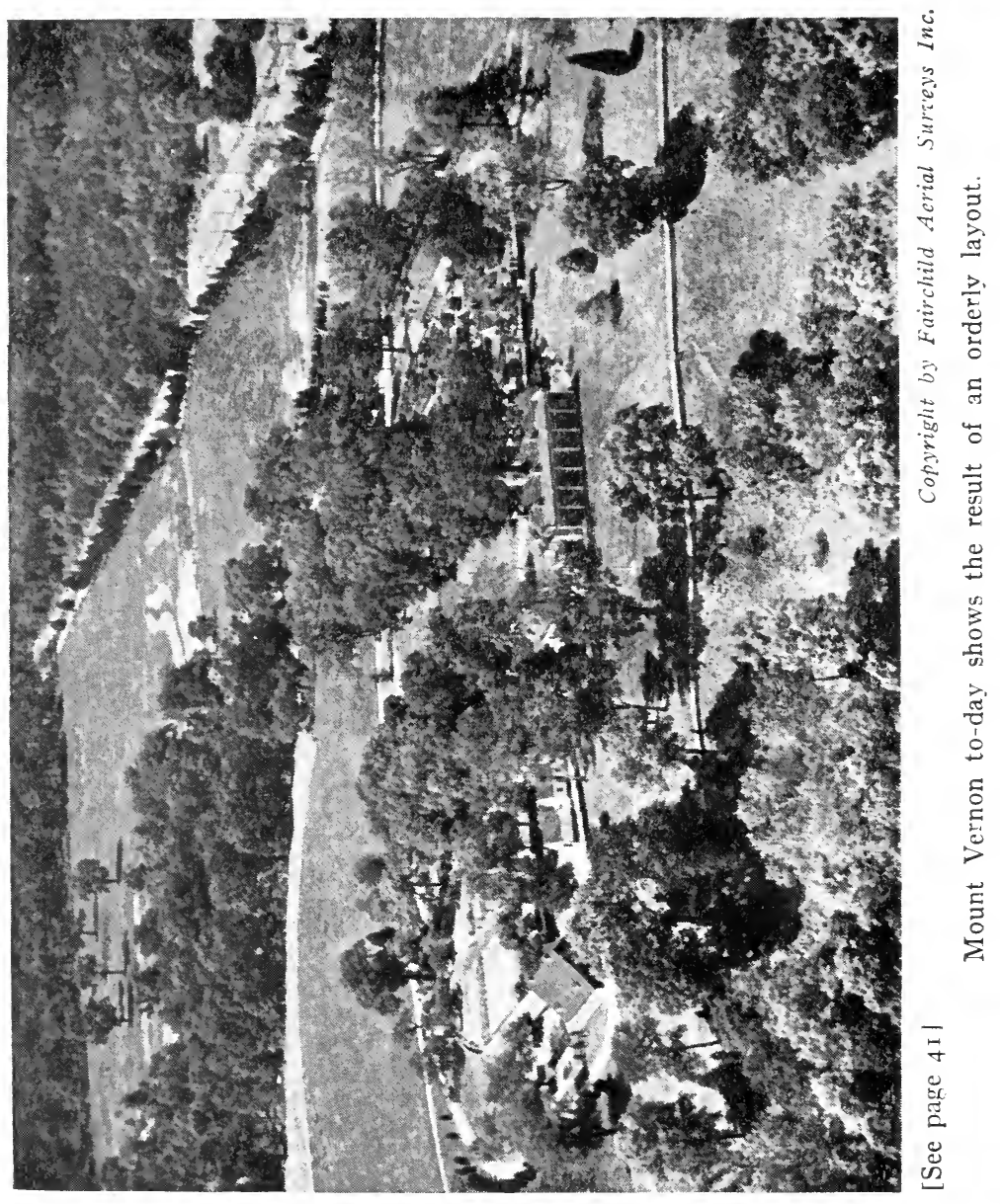




\title{
LAND PLANNING IN THE UNITED STATES for the CITY, STATE and NATION
}

\author{
BY \\ HARLEAN JAMES, A.B. \\ SECRETARY OF THE AMERICAN CIVIC ASSOCIATION AND THE FEDERATED \\ SOCIETIES ON PLANNING AND PARKS
}

PREFACE BY

RICHARD T. ELY, LL.D.

PROFESSOR OF ECONOMICS IN NORTHWESTERN UNIVERSITY

INTRODUCTION BY

ALBERT SHAW, LL.D.

$\mathfrak{n} \mathfrak{e}$ w 县ork

THE MACMILLAN COMPANY

1926 
Copyright, 1926,

BY THE MACMILLAN COMPANY.

Set up and electrotyped.

Published September, 1926.

Printed in the United States of America by J. J. LITTLE AND IVES COMPANY, NEW YORK 


\section{PREFACE}

The present work of Miss James marks an advance over earlier works on city planning. Planning may be regarded as the heart of our agricultural as well as our urban land problems. Prudent utilization of all our natural resources is not possible unless planning extends to all the other forms of the utilization of land, and this means that our mineral resources, water resources and forests must be planned both for the present and for the future. In other words, conservation is a problem of planning.

Practice in our own country is very generally broadening its scope so as to take in the utilization of various classes of land. City planning is now making way for regional planning, or, perhaps one should say, is becoming part and parcel of regional planning. It is quite evident that the regions surrounding an incorporated city are closely tied to it, even before they gradually become united to it legally. The metropolitan area must be planned out carefully if we are to have the kind of cities we desire, and the earlier the planning the larger the results accomplished with given expenditures. We see clearly on every hand the enormous loss involved in rectifying mistakes that could easily have been avoided with wise planning.

But many yet do not see that agricultural prosperity, and consequently the prosperity of the country as a whole, depends upon the planned out utilization of agricultural land. Moreover, the utilization of agricultural land cannot be well planned unless agriculture is considered in its relations to utilization of land for forests, for recreational purposes, for urban uses and all other possible uses. The troubles of the farmers now 
are essentially due to the fact that we have not had wise planning in the utilization of land. A great deal of land that should be producing crops of trees is now producing other kinds of crops and very generally at a loss, because the land is poor land for agricultural purposes. We have the further result that food at high costs is dumped on the market and produces the phenomenon of a surplus that is disturbing us economically and politically.

It is only as we make a synthesis, taking in the planning of land as a whole, that we can have the foundation of the highest attainable economic prosperity. Miss James' work as Executive Secretary of the American Civic Association is well known and her articles have attracted widespread and deserved attention. She has in her own thinking and in the title of this book kept pace with the development of land planning. At first the book was conceived of as a book on city planning but has now become "Land Planning in the United States for the City, State and Nation." It thus performs a useful function in instruction and in blazing a trail for others to follow.

Evanston, Illinois,

RICHARD T. ELY. June, 1926. 


\section{INTRODUCTION}

\section{By ALBERT SHAW}

We have turned fairly into the fourth century of the economic conquest of North America by people of European stock. They came to make homes, and to give form in the wilderness to social and political ideas that were only in part a heritage. For along with things familiar by reason of traditional experience, they brought the dawning hopes and aspirations of a new epoch. The colonists of necessity accepted prevailing European theories regarding sovereignty over landed domains, as inherent in the crowns of Great Britain or France or Spain. The holding of land was the dominant economic and political motive in the founding of the American settlements. Charters were granted under which large specific areas became distinct crown provinces.

The conditions of pioneer life, together with the circumstances under which colonists were brought over and assimilated, tended rapidly towards equality of status. Feudal traditions could not well survive in these new communities, where land was far more abundant than labor. In New Englandcolonization being relatively compact and surroundings austere - the occupation of land advanced by creation of new parish groups or so-called rural "towns." These new townships, steadily pressing the frontier further westward, were constituted by virtue of the higher provincial authority, consent of the Indians having been duly acquired by purchase or by force. The new towns were more or less carefully laid out, with allotments of land to each family for a homestead on the broad village street and for fields and woodlands in the outskirts.

There were some reminiscences here of old English agri- 
culture; but the American system soon adapted itself to actual necessities. The towns were small democracies, fairly well planned in view of the meagre opportunities of the seventeenth and eighteenth centuries; and they maintained a life of dignity, thrift, and comfort that had survived well into the nineteenth century, and that justly excited the admiration of Tocqueville and other European visitors.

In Virginia and the colonies lying to the southward, stretches of available land were far more extensive relative to the number of pioneer settlers who came with capacity and ambition and with some material resources. The broad estuaries that penetrated deeply into these regions made large landholdings with water frontage available for a great number of plantations.

There arose an almost frenzied demand in Europe for tobacco; and the tidewater areas of Virginia, Maryland, and the Carolinas were devoted largely to the raising of this crop for export. The habit of specialized kinds of commercial agriculture persisted in the South, and became still more general and profoundly influential when it was discovered how well fitted were our southern lands for cotton production, and how insatiate was the world's demand for cotton fibre. These characteristics of southern agriculture were faithfully reflected in the economic and social institutions that took form south of Pennsylvania.

In New York, the early Dutch settlements which stretched up the Hudson valley to Albany and penetrated the valley of the Mohawk were formed under a system of large proprietorship having some feudal aspects, which, however, in due time disappeared. There followed the ordinary and familiar American type of independent farming. Pennsylvania in turn was to a great extent shaped by the planning of William Penn and his successors, while in extensive districts the farming methods and social customs of the Germans of the upper Rhine valley and Switzerland became so well established that they persist today. 
The great New England exodus spread across central and western New York with brilliant success. In the early part of the nineteenth century it utilized the excellent lands of northern Ohio, and so swept steadily westward across Indiana and Illinois. Meanwhile, the agriculture of tidewater Virginia was destroying soils and driving the independent farmers westward, first to the Shenandoah Valley and then to Kentucky and southern Ohio, while the Carolinians advanced to the conquest of Tennesssee and thence to Missouri. In due time the Georgians and other farmers of the South were carrying cotton culture to the new lands of Alabama and Mississippi, with Arkansas and Texas awaiting their inevitable advent.

Following the settlement of Ohio after the Revolutionary War, by virtue of the movement that was stimulated under the land-surveying activities that accompanied the adoption of the Northwest Ordinance, there came the gradual extinction of Indian titles in Indiana, and the opening up of the southern parts of Michigan and Wisconsin. After the Louisiana Purchase and the Missouri Compromise, there came the rapid settlement of the rich prairie lands of Iowa, and the opening of southern Minnesota, while in due time began the strife between northern and southern settlers for the control of Kansas. The Mexican War, the finding of gold in California, the annexation of Texas and the acquisition of the Mexican areas of the Farther West, lead to those stupendous movements that made California a factor on the northern side in the Civil War while in similar fashion Texas loomed up as a stronghold of the Southern Confederacy.

Meanwhile, European conditions were sweeping great tides of migration to our shores, and the Scandinavians and Germans were joining our older elements of population in taking advantage of the homestead laws and of the settlement policies of the land-grant railroads, and were developing Nebraska, the Dakotas, and the Farther West.

This movement of the pioneers, magnificent as it seems in the retrospect, has not been thorough or complete or otherwise 
than speculative, spasmodic, and destructive of natural resources. When the twentieth century arrived, it was easy to perceive by the most casual survey that we had made terrible waste of our forests. We had swept away enormous areas of white pine, without leaving mature trees enough to provide for natural reforestation. We had destroyed vast forests of the most valuable hardwood timber in the world, in order to secure inferior hillside lands for farming and pasture; and then had lost the soil from these lands by erosion.

Having ruined millions of acres of southern lands by bad tobacco farming, and by equally improvident cotton growing, we had destroyed other millions of acres by failure to apply the simple principles of permanent farming and crop rotation in the raising of wheat and corn. Bad systems of land taxation, and a deep-seated national habit of speculation in land values, had joined with other causes to militate against the stability of rural life.

George Washington and Thomas Jefferson in Virginia, Mr. Livingston in New York, and many other men of weight and character, were endeavoring, as the nineteenth century opened, to teach the country how to restore soils, promote agriculture, and create a permanently prosperous rural society. Their lessons were taking deep root throughout the States of New York and Pennsylvania, throughout upland Virginia, and especially in such states as Kentucky, Tennessee, Ohio and what is now called the Middle West. But the improved system of diversified farming-with live stock, clovers, and an understanding of the methods by which the soils of England and France had become increasingly productive-was met by two new tendencies of almost overwhelming character.

First was the rapid development further west of the wheat and grain crops from new land, and of the cattle and sheep industries of the plains. Agriculture all the way from the Mississippi River eastward to the Atlantic was subjected to the competition of an immense surplusage of breadstuffs produced on prairie lands that had cost the owners nothing, and 
of meat from the boundless grazing stretches of the plains.

The second tendency resulted from the expansion of American manufactures, causing the drift of population from country villages and farms to manufacturing towns and commercial cities. This urban accretion was sapping the virility of that great rural civilization which had been the mainstay of our American institutions. The farms and their village centers had represented far higher standards of intelligence and virtue, of physical health and vigor, and, in short, of what was best in American life, than our cities and larger towns.

With the dawning, then, of the twentieth century, we were facing a series of new problems of adaptation. These called for a taking of stock, a study of underlying economic and social conditions, and a readjustment of views in order that our situation might be grasped as a whole.

We had become acutely aware of the so-called city problem before we had realized that a not less formidable problem of the countryside was presenting itself. The city problem assumed large proportions and took on many aspects. Political corruption in the larger cities of the United States was invalidating national elections and was poisoning the integrity of parties and of democratic government.

The municipal corporations themselves were notorious for maladministration. There was poverty, overcrowding, and flaunting vice. Police departments were in partnership with the liquor business, and the drinking saloon was the rendezvous of disorder and crime. Epidemics were prevalent; death rates were frequently higher than birth rates; and observers like James Bryce found the misgovernment and the corruption of American cities the most conspicuous of the shortcomings in the life of the great American democracy as he studied it in the last quarter of the nineteenth century.

Meanwhile, modern European cities had been confronted with problems similar in many respects. But they had found, for their municipal corporations, more efficient forms of administrative organization than we had adpopted in the United 
States. As regards overcrowding of populations, bad housing, ill health and poverty under urban conditions, epidemics and high death rates, these European cities presented in more intense fashion the same kind of social phenomena as those of our own commercial and industrial centers.

It is to be remembered that standards of living for working people, whether in town or in country, had everywhere in Europe been exceedingly low. The life of a typical agricultural laborer, as Arthur Young and other observers found it in the British islands at the beginning of the nineteenth century, was on a scale so reduced as regards shelter, food, and clothing as to be incredible today to any except careful students of economic history. And the life of the artisans and handworkers in the villages, previous to the use of steam power and the development of the factory system, was only a little better than that of the common laborers.

It was not to be expected, therefore, when the factory towns arose and new populations crowded into them from the rural villages and the countryside, that any preparation whatsoever would have been made for suitable housing or for sanitary services. Low standards of living in the country had at least been mitigated by comparatively wholesome surroundings. But in the towns there was fearful overcrowding, with lack of proper food, infected water supplies, the constant presence of epidemic diseases, and the desperate poverty due to all these conditions, together with drunkenness, vice and criminality.

The emergence of European town life-all the way from Scotland to Hungary-out of this terrible plight, is principally the story of the application of discoveries in preventive medicine to public administration through health officials. In detail the story is a long one, while the conclusions may be summed up in a few sentences. With vaccination and effective quarantine, small-pox epidemics disappeared; with pure water and milk under. the guidance of bacteriology, typhoid was eliminated; and thus, step by step, public health depart- 
ments transformed the conditions of city life. Overcrowding and housing conditions were dealt with officially; and engineers, economists, research students in laboratories, architects, and men of other special and technical qualifications, assailed the complex city problem with all the resources at their command.

They obliterated slum districts and built model tenements. They studied the maps, opened new and wider streets, laid out suburbs for purposes of industry and residence, and placed firm checks upon the haphazard growth of urban communities. Great cities like Berlin, as early as 1885 , had studied the environing country for miles in every direction, and had drawn maps in detail for the extension of radiating street systems, with the location of parks and other permanent features of the metropolitan plan. Provision was thus made for the control of the expansion of the metropolis for at least a hundred years in advance. Everywhere in Europe there came order and system through planning and foresight. What we now call the zoning system, which has come into active and general use in the United States within a few years, had been in universal use as a matter of course throughout Europe long before the end of the nineteenth century.

Our American treatment of the great city problem, then, has merely followed the European solutions. We have, however, so well trained our own experts that we have quite outgrown the need of foreign instruction, except as any community may derive one suggestion or another from the study of experience elsewhere. We are indeed far from having made complete or perfect application of new ideas in scientific discoveries to the improvement of towns and cities, but we no longer stand in awe of a vast overshadowing problem that baffles us. When we make comparison with the conditions of thirty or forty years ago, we are optimistic.

The educational systems of our cities are vastly improved, and through them we are able to measure the physical as well as the mental progress of the rising generation. Abject pov- 
erty of the chronic type is greatly reduced; safeguards thrown around women in employment are relatively excellent; epidemics are a thing of the past; and the death rate is reduced by half. So far as appearance is concerned, there are no longer any class distinctions. School systems make education available for all who have capacity for mental advancement. The political conditions that were so alarming forty or fifty years ago have been almost completely reformed. These conclusions will not be regarded as too complacent by those who have intimate knowledge of the facts which must be brought into contrast in order to understand how great has been the change for the better.

But all this does not mean that we have come somewhere in sight of the end of progress in the ordering of our cities and towns. It means, on the contrary, that we have sufficiently cleared away the preliminary obstacles so that we may now proceed constructively, to make our towns and cities worthy of our best conceptions. The author of the present volume, Miss Harlean James, has not merely compiled salient facts regarding the problems of planning as they relate to the present and future. She has long been a diligent student of these subjects, is highly trained in all that pertains to modern social progress, and has been an inspiring worker and adviser in practical movements for the remaking and modernization of our American communities.

As executive secretary of the American Civic Association, Miss James has had unusual opportunities and advantages. This Association, in close coöperation with other societies, has brought together public-spirited men and women including many architects, landscape gardeners, housing experts, park planners and executives, social workers, municipal authorities and public-spirited leaders of particular communities.

From a period of striving for the reform of municipal government and the correction of the errors and evils of city life, there has arisen an understanding of certain larger things of which the so-called city problem was merely a part. In its 
most comprehensive aspect, the vision that holds the attention of our present day leaders is that of a better world. They see the health problem in its international aspects. While they are laying the foundations for our twentieth-century Florida by abolishing the fear of yellow fever, Asiatic cholera, and other epidemics (this furnishing no small part of the explanation of Florida's delayed utilization) they are also shaping a new era for the West Indies, for Central and South America, and for great tropical areas in Africa.

These changes in health conditions are rapidly followed by agricultural and economic developments that in turn serve to improve the daily opportunities of millions of people. But while this vision of a better world has dawned so definitely for many leaders in this period, who see the value of the International Institute of Agriculture at Rome and of the International Labor Bureau of Geneva, as well as of International Health movements, it is obvious that still larger numbers are able to entertain the conception of a better America. They begin to understand that, while through three centuries we have been making an American nationality, and have been pioneering the wilderness from one ocean to the other, we have now before us the business of bringing together, into a more perfect blending, the American population and the American domain.

In other words, we have to make the United States over again, on permanent lines. This means the country as a whole in its large features of physical and economic geography-its plains and mountains, its forests, its arable soil, its flowing and navigable waters, its vast resources of hydro-electric power, its undeveloped wealth of coal, of oil, of minerals, and so on. The vision of a better country, through the wise use and conservation of its resources, was given definite expression and transformed into a scheme of public policies and programs by the historic conference on the conservation and use of America's natural resources called by President Roosevelt in 1908, which brought together at the White House 
the Governors of the respective States, with a number of distinguished leaders and experts.

In the present volume, Miss James sets before us in orderly fashion the history and progress of this movement for saving the country from a further squandering of its precious resources that become ever more valuable as our population grows, and as the freedom to travel and to enjoy becomes a possession of that average man who was not long ago tied closely by circumstances to his rural parish or to the pavements of his native town.

While certain formulas for the improvement of towns and cities have now been so well tested and tried that no intelligent person rejects them, there has come to be a new cause of anxiety in the apparent decline of thousands of country neighborhoods, and in the relative failure of rural and farm regions to maintain the traditions of dignity and of superiority that were formerly theirs by common consent. We have been solving the problem of the cities, not by going backward to reëstablish some earlier state of things when there were flourishing guilds and prosperous burghers, but by utilizing new forms of coöperative service such as good streets, pure water, perfect lighting, excellent police, fire, and health appointments, the best of schools and libraries, parks and playgrounds, fresh air funds, and many other agencies for welfare, all engaged in making town life healthful and wholesome, as well as pleasant and stimulating.

The problems of rural reconstruction are not to be solved by admonishing young men and young women against the perils of the city, or by laying it upon their consciences to live toilsome and drudging lives, such as their pioneer grandparents lived, upon farms that lack buth beauty and comfort, and that yield no adequate economic return for hard labor and for the investment of carefully saved capital.

The rehabilitation of our country districts is essential to the future welfare of the nation. But the happiness and prosperity of rural neighborhoods is not to be brought about by 
fruitless attempts to check natural movements of population in a period when travel is easy and when labor naturally and properly seeks the best markets. There lies spread out before us a great field for the application of statesmanship to conditions that are presented in each one of our commonwealths by the disclosures resulting from economic and social surveys.

Thus, we have allowed the wealth of our States to become very largely concentrated within the limits of our larger municipal corporations. A mistaken system of taxation applies the wealth of the community to the provision of the best possible schools for all children living within city bounds, while it is left for children in the country districts to be supplied by the taxation levied upon impoverished farms. This is not merely an outgrown survival of the crude pioneer practice of local independence in such matters, but it is deadly in its destructive influences. Those who would plan for the maintenance of prosperity throughout the domain of a great State like New York or Ohio should begin with the simple principle that taxation for school purposes should not be levied locally, but should derive from all the taxable property of the State a fund which should then be so distributed as to give every child in the commonwealth equality of educational opportunity.

In similar manner, the road system should be so constructed and maintained that country children could be easily and freely transported to school centers, in this matter following the admirable example of California, where the county high schools serving the rural districts are among the most beautiful institutions to be found anywhere in the world, while well adapted to their objects. Again, in like manner, it should be an affair of public policy to see that every rural district has its medical and nursing center, with model hospital facilities, so that physicians and surgeons of the highest standards, with automobiles and motor ambulances utilizing good roads, could readily reach every farm home.

The rural free delivery system is an expression of national policy-making for the permanent welfare of the countryside. 
National and State departments of agriculture, with experiment stations, county institutes, county agents, and officially encouraged coöperative marketing enterprises, are all helping to restore the life of rural communities. They work upon the plan of bringing to that life the most modern facilities, disregarding the hopeless notion of trying to keep the countryside contented with things that might have been accepted through grim necessity a hundred years ago. It should be made a matter of explicit public policy to see that throughout our States, as now throughout Switzerland and other adjacent regions of Europe, there is uniform distribution of all forms of cheap electric service of light and power, which could go far to bring the standards of country life up to those of the modern town.

The vision which encompasses a better country, which looks to reforestation of white pine in the North and of the longleaf turpentine pine in the South; to national parks; protected streams; utilized water powers; irrigation, drainage, and various other features of a modern conservation policy, may in turn be applied locally to each of our forty-eight States, and hardly less importantly to thousands of counties, villages, and townships. There is something inspiring in the thought that the planting of trees upon some well-considered system, with very slight present expense, may add immeasurably to the beauty and wealth of one's own neighborhood for a long time to come.

The finished beauty of many parts of England and France is not an inheritance from the Middle Ages, but is actually a creation of men and women living since the beginning of the nineteenth century. There is hardly a nook or corner of France that was not affected by the magnificent nation-planning of the First Napoleon. The French national highways are today the delight of motorists, connecting the centers of all the departments, while the roads of the departmental and arrondissement systems form logical parts of the great ramification. The rural prosperity of France, remaining today 
the most important and indestructible of French assets, is largely the outgrowth of the national planning of Napoleon and of his military and civil administrators.

It was the Third Napoleon who had his vision of a reconstructed and modernized Paris, executed largely in his own time under the direction of Baron Haussmann; and while this vision had less relation to the social condition of the people than to the grandeur of the city, it so happened that these reforms in Paris actually led the way in a movement for reconstruction that demolished hideous slums in hundreds of European cities and that was in harmony with the spirit of sanitary and social reform that has achieved such triumphant results.

The transformations of Germany, both municipal and rural, have been largely wrought since modern Germany attained its new impulse after the Franco-Prussian War of 1870 . Much of the most beautiful and productive country in England consists of former coastal marshes or inland moors that have been redeemed and brought into inhabitancy and use since the period of the American Revolution.

We have then before us the inspiring problem of working out the magnificent possibilities of our country as a whole, and of its States and localities in detail. Any man, woman, or child who learns to cultivate flowers in a village lot, and to provide for shade trees and fruit trees where they had not existed, is doing his share toward perfecting the pattern of a beautiful country.

It is worth while to consider how these problems in their general character as well as in their details are grasped by some of our present thinkers and leaders. Thus Professor Richard T. Ely, who founded some years ago at the University of Wisconsin the Institute for Research in Land Economics and Public Utilities-a movement of remarkable scope and character that is now associated with the Northwestern University at Evanston and Chicago-was one of the earliest and most profound of the American students of municipal 
conditions. Having made a career in the solution of the economic and political problems of life in cities, Dr. Ely with his numerous expert associates is studying all the problems that pertain to land development, agriculture, and the best progress of rural communities, while also directing studies in the rehousing of city populations.

What Dr. Ely clearly perceives is the underlying unity of all these problems. He sees before us the need of adjusting the country as a whole to its opportunities. How shall we make our resources serve our population in its entirety, while we beautify and enrich the national heritage that we pass on to the generations that are to follow us? It is worth while for every community that has a proper sense of local pride to remember that the future is largely affected by the foresight and the public spirit of those who are now on the scene.

Those who predict the decline of England evidently do not understand that England could not possibly fall into that state of decay that Macaulay suggested in his prophetic allusion to a New Zealander surveying the ruins of London from the ancient bridge. The accumulation of artistic, economic, and historic assets is so great that mankind could not afford to permit its desertion or decay. England will come valiantly through all the difficulties that have followed the sacrifices of the Great War, because England is England if for no other reason.

Our really achieved examples of civilization do not decline; but on the contrary they improve with the growth of scientific knowledge, with higher ethical standards, and with the steady leveling upwards of our democracy.

And, this being true, our civilization will not abandon its treasures. Men will continue to live and work where they have accumulated the facilities by means of which they live, and where they have assembled the treasures of architecture and of artistic and natural beauty that belong to countries like England and France. The prosperous citizen of New York 
or Chicago, who goes back to the village of his birth and builds a library, or who contributes in other ways to the beauty and charm of the region where his ancestors were pioneers, is helping to tide over a period of transition. He plans well to dignify the traditions of the past, in order that the community in future times may enjoy that sense of historic continuity that it is the privilege of every neighborhood to cultivate and cherish. History is henceforth to be made by deliberate planning, and by conscious intention. 



\section{CONTENTS}

\section{INTRODUCTION}

Planning mark of progress-Permanence of boundaries and roadways-Purpose of democratic communities-Individual and community planning-Relation of the population to the land-Growth of the population-The rate of growth-Increase in area of United States-Increase in urban and rural population-Dwellings built in the United States-Our land resources-Opportunity for intelligent planning . . . . . . . . . . .

PAGE

\section{Section I. Begrnnings in American Planning}

I. Early Land Policies in Layout-Boundaries of early grants -Virginia practice, New England practice-The National system of surveys-Routes of roads-Local connections - Main thoroughfares of country travel-Water and rail routes

II. Layouts of Early Settlements-New England-New York -Virginia-Plans for Populous Cities-Boston-New York-Philadelphia-Western cities-Reclamation towns -Washington, the Capitol city-Early farm plans.

Section II. Modern City Planning, Its Aims And ACCOM PLISHMENTS

III. Short History of City Planning in the United States-The World's Fair and architecture-Co-operation of architects, landscape architects and engineers-Landscape design-Centennial Celebration of Establishment of Federal City-Professional Organizations of architects and landscape architects-The American Institute of ArchitectsThe American Society of Landscape Architects-Municipal Engineering-Housing Reform-Organization of City Planners-Dealers in Real Estate-Need for trained economists

IV. Civic Improvement and City Planning-The American Civic Association-Typical American town-Improvements-The "City Beautiful"-The Federated Societies on Planning and Parks 
V. Principles of City Planning-Definition-Long-range and short-range programs-Circulation-Parks and Open Spaces-Public Buildings and Grounds-Zoning-Sectors

VI. Street Systems-Layout-Miles of new streets-Radial growth-Arterial highways-Classification of trafficMain thoroughfares-Major traffic streets-Minor streets -Technical advice-Alleys and lanes-Footways-Pleasure roads and boulevards

VII. Street Systems-Width and Arrangement-Encroachments on public streets-Street widths-Arrangement of streets -Business streets-Residence streets-Street furnishing -Street markings-Street trees . . . . . . .

VIII. Traffic and City Streets-Congestion of traffic-Regulation-Segregation-Two and three-level streets-Decentralization - Memphis - Pittsburgh-Chicago-Philadelphia-Detroit-Saint Louis-Los Angeles-Freight carriers in streets - The automobile and the suburbs . .

IX. Transit and the Street System-Public conveyances in the streets-Rapid Transit-Surface-elevated-subway lines -Ferries.

X. Transport - Entrances - thoroughfares-Rail-ChicagoNew York-Rail service for industrial sections-Grade crossings-Water-Bridges-Air . . . . . . .

XI. Public Parks and Open Spaces-Classification of public outdoor recreation areas-Transportation and parksPlaygrounds-Parks and the city plan-Park uses-Land values and parks-Purchase of parks

XII. Blocks and Lots-Sizes-Arrangement-Philadelphia-Chicago-Residences-Apartments-Commercial buildingsIndustrial establishments_Platting . . . . . .

XIII. Buildings-Public buildings-Civic Center-New YorkSan Francisco-Denver-Washington-Private buildings -Skyscrapers

XIV. Zoning and Its Relation to Comprehensive Planning-Zoning-Use districts-Height districts-Area districts-Designation of use districts-Non-conforming uses-Classification of uses-Blighted districts-Neighborhood stability-Danger in ready-made zoning law-New YorkSetback regulations-Billboards-Zoning and the Constitution-Court decisions

XV. Regional Planning-The Boston Region-The Los Angeles Region-Theory of regional planning-Circulation of traffic-Zoning in metropolitan regions-Distribution of the industries-Regional planning and open spaces-Un- 
official regional plan associations-Planning new subdivisions within the region-Private restrictions-The time element-Satellite towns . . . . . . . .

XVI. City Planning Procedure-Citizens' Committees-Official Plan Commissions-Zoning Commissions and Boards of Appeal-Municipal Art Commissions or Juries-City Park Commissions or Departments-Regional Plan Commissions-State Enabling Acts-Definite ProgramPreparation of the Comprehensive Plan-City Planning surveys-Personnel-Public education-Continuous application

XVII. The Cost of City Planning-Cost of the Plan-Cost of specific projects-Projects charged against general taxation-Special assessments-Excess condemnation-Arbitrary assessment districts-Pyramiding projects-Significance of the city plan-Economic considerations in changing the map in crowded cities-Easements and setbacks-Other adjustments

\section{Section III. Natronal and State Planning}

XVIII. Piecemeal Land Planning-Area of the Republic-Disposition of the public domain-Permanent public landsPresent ownership of public domain-Balanced land uses -Public domain and communication-Mineral and oil lands-Power resources-Principles of city planning and zoning applicable to nation

XIX. Putting Land to Its Proper Use-Characteristics of landlegal-physical-economic-The land inventory-The Institute for Research in Land Economics-The Michigan Land Economic Survey-The Inventory-Land Classification-Classification of Natural Resources-Land Planning.

$\mathrm{XX}$. The Forest Lands and Cut Over Areas-American Forestry Association-Federal Service-Principles of Land Use-Classification of 'Lands by the Forest ServiceGrazing as a secondary use in National Forests-Priority of uses in the National Forests-Economic considerations

XXI. Recreation Areas and Scenic Assets-The wilderness-National Parks-Recreation areas in the National ForestsState Parks and Reservations-Rural recreation spacesCo-ordination of National, State and local planning .

XXII. The Water Resources of the United States-NavigationWater power-Water for irrigation . . . . . .

XXIII. Land Communication-The Old National Road-Transcontinental trip in 1859-Federal-aid roads-Lincoln 
Highway Association-Other highway associationsAmerican Automobile Association-Bureau of Public Roads-State Highway systems-Arrangement of State Highways-Motor traffic-Railways-Telegraph and telephone wires . . . . . . . . . . . . 384

XXIV. The Great Agricultural Lands-Lack of plan in growing crops-Marketing-Size of farms-Land surveys-Acres in crops-Ranches and grazing-Colonization schemes .

XXV. Federal and State Planning Agencies-Federal-owned land - Clearing House for Land owned by the Federal Government-Federal agencies rendering service for private lands-State and County Buildings and Grounds-State Capitols and County Seats-State action in planning and zoning-State Land Boards-State Forest CommissionsState Park administration

Conclusion

INDEX • 


\section{ILLUSTRATIONS}

Mount Vernon to-day shows the result of orderly layout . . Frontispiece PAGE

Plan of Williamsburg, Virginia, adopted in $1699 . .30$

The L'Enfant Plan of the Federal City . . . . . . . . 37

A New Hampshire Farmyard laid out about 1800 . . . . . 40

Map of Philadelphia . . . . . . . . . . . 49

Cleveland's radiating highways . . . . . . . . . . 100

Map of Boston . . . . . . . . . . . . . . . 103

Changing the Map in Boston . . . . . . . . . 105

Niagara Square, Buffalo, an open space in the downtown section .

Op. 125

Street with ugly, dangerous signs-Same street with overhanging

signs removed . . . . . . . . . . . . . 127, 129

Pleasant vista showing uniform planting of street trees . . . 132

The tall buildings of New York . . . . . . . . . . 139

Map of Pittsburgh . . . . . . . . . . . . . . . 147

The Gateway to a Greater Chicago . . . . . . . . . 149

Before and after cutting through Fairmount Parkway, Philadelphia

Op. 150

The Ciry Hall in Detroit completely surrounded by skyscrapers.

Detroit is struggling to distribute its traffic. Why not distribute

its buildings? . . . . . . . . . . . . . Op. 151

Widening city streets by establishing a setback for new buildings 164

Map of San Francisco . . . . . . . . . . . . . 169

Map of New York City . . . . . . . . . . . I70

Bird's-eye view of Atlanta, Ga., showing Terminal Station, the

Spring Street Viaduct and the heart of the business section.

Map of Chicago . . . . . . . . . . . . . . . . 179

Union Station, Washington, Rail Entrance to the Federal City . 182

Bush Terminal, Brooklyn, where thousands of cars discharge freight

on wharves and to warehouses . . . . . . . . 184

Two-level Railway and Highway Crossing . . . . . . . 186 
Portland, Oregon. Entrances by rail, water and bridges . . Op. 185

Map of Seattle . . . . . . . . . . . . . . . . 189

Central Business Section of Seattle, showing Harbor . . . . Op. $\quad$ I89

Washington and High Bridges connecting the boroughs of Man-

hattan and the Bronx . . . . . . . . . . . . . IgI

Shady paths in Branch Brook Park, Newark . . . . . . 197

Playground with intensive development . . . . . . . 203

Public School placed in ample grounds . . . . . . . . 205

Skyscraper Municipal Building of New York . . . . . 218

Civic Center, Springfield, Mass. . . . . . . . . . . . 220

The Capitol in Washington showing public buildings not protected from surroundings . . . . . . . . . . . Op.

Contrast between the White House and Treasury, public buildings, and private buildings . . . . . . . . . . . Op.

Twentieth Street in Birmingham, Alabama. How many more skyscrapers will the street accommodate? . . . . . Op.

"Broad" Street, now too narrow to serve the day population of the tall buildings.

?n rooms with black windows tenants were using artificial light at noon on a bright sunny day. .

Need of Zoning height restrictions in Dallas. Can the streets carry the traffic from more tall buildings? . . . . Op.

Pisgah National Forest in the Southern Appalachian Mountains .

Op. 347

How can this land be used? Cut-over lands in California . Op. 353

Paradise Valley and the Inn, Rainier National Park, with the Mountain and Nisqually Glacier in the background. No one can doubt that the highest use of this land is as a National Park

Falls in the proposed Shenandoah National Park in Virginia .Op. 359

California Redwoods which may be preserved in a State Park System

South Fork Eeel River at Bolling Grove, California . . . Op. 365

Turkey Run State Park, Indiana. Evening on Sugar Creek . Op. 367

New Orleans, with its extensive waterfront, may be connected by

Inland Waterway with the Great Lakes.

Distribution water power resources of the United States . . . 3 379

Distribution of and extent of development of water power resources

of the United States.............. . $38 \mathrm{I}$

Where land and water meet. San Francisco Harbor. . . . Tailpiece 
LAND PLANNING IN THE UNITED STATES FOR CITY, STATE AND NATION 



\section{INTRODUCTION}

Planning Mark of Progress.-One of the great marks of progress in any civilization is the ability of its members to plan a project before it is executed. The first crude bridges which superseded the earlier fords or ferries were simple to imagine and simple to construct. But the complicated steel bridges which now span our broad rivers and support heavy locomotives and cumbersome freight cars must be designed with great detail. Drawings are made showing the exact size and shape of each piece of steel and the correct pattern of every bolt and rivet so that the entire bridge may be delivered on the ground ready to be put together. The completed bridge, if it is well designed and well constructed, will meet the requirements placed upon it. A little town of ten or twenty houses may be, and often is, started with no more planning than would be required to lay heavy planks across a narrow stream. Frequently the physical arrangement which results from this unthinking beginning will not bear the subsequent strain put upon it. People who live in thousands of American towns to-day still suffer from the casual acts of the early settlers.

Permanence of Boundaries and Roadways.-Roads and boundaries have a tendency to become permanent. Towns have been divided into bitter factions over proposed changes in location of streets. Law suits have been fought over line fences. Boundary lines of house lots are difficult to rearrange: In cities it is seldom possible to purchase complete contiguous areas from a large number of owners. A single stubborn owner can refuse to sell a key plot and thus block the rearrangement of lot lines through the method of private purchase. In the case of city streets, the stupendous investment of capital in 
the buildings which face upon one block presents a formidable obstacle to changes in street locations even where the right $\checkmark$ of eminent domain is exercised.

Even in young America we walk to-day on many a road or street which has survived from the 17 th or 18 th century. Through the length and breadth of our United States this generation is attempting to use lots and blocks which were laid out to meet the customs of frontier settlements. By the time it was discovered that the streets and blocks were not adapted to the use to which they were being put, the town had grown into a city; brick, stone and steel buildings had been erected along streets too narrow to carry the traffic; the interiors of the blocks too large in proportion to their street frontages had been covered with alley or court buildings and the intensive use of the land had increased values to the point where property rights weighed heavily in the balance when proposed changes became an issue. The widening of a city street through the length of one brief mile is a colossal undertaking. A street must ordinarily be congested to a degree dangerous to life and limb before the public will consent to force the owners of tall buildings to cut a few feet from the imposing fronts of granite structures planned for an important thoroughfare.

Purpose of Democratic Communities.-Entirely apart from the provision of facilities to care for the great numbers of people who have gathered in our crowded cities we are obliged to meet the demand for higher living standards made possible by advances in science. What is even more significant, we have definitely set up for ourselves the aim of caring adequately for all of our people. In our Republic we have been a little slow, perhaps, in coming to the full realization of our opportunities to plan and build American communities worthy of American citizens. We have concentrated more generally upon the machinery of government. While we may hope for continuing improvements in the forms of local selfgovernment we are here concerned with it only to the extent 
by which we may work through government to provide good living conditions.

The purpose of our democratic community is quite different from the purpose of an imperial city built around a dazzling palace. The modern country village does not resemble the feudal manor built for the retainers of the lord of the castle. The city of to-day, which provides undreamed-of facilities for enriching and ennobling life, is slowly displacing the strictly industrial municipality which grew up in the first period of factory corporations, owned too frequently by non-resident stockholders. Our industrial expansion was so rapid and the profits in some instances so fabulous that it is not surprising that living conditions were often neglected. We must, therefore, assess at its true value the recognition of a new ideal for the living and working conditions of the people of this country. We hold the belief that there shall be provided in each community for every man, woman and child healthful living and working quarters, capable of being supplied with light, air, water and heat. We sometimes fall far short of this ideal but we recognize it and we are constantly working toward its realization.

Individual and Community Planning.-Every farm, no matter how isolated, is the result of some sort of planning, good or bad, on the part of the occupier or owner and on the part of the community. No farmer can grow crops without determining the size and shape of his fields and the succession of uses to which he will put them, and these decisions, in turn, are dependent upon the fertility of the soil, the topography of the land and the exposure of the fields. The size, type and location of his house, his barns, his tool sheds and his storage buildings were all determined by him or his predecessors. The shape, if not the size, of his farm, however, has generally been determined for him either by early surveys or conditions of settlement. The location of the public roads, the school house, the church, the court house, the market town and the railway shipping station, are, ordinarily, not matters 
within his individual control, except in so far as he may have exercised his preference in the selection of one from available farms. He has usually inherited from the past a fairly arbitrary arrangement in these matters which he is inclined to accept as fixed.

Likewise the individual resident in a town travels daily on streets laid out in a pattern not of his choosing, lives in a house placed on a lot which is part of a block with limits determined by the lay-out of the streets. He and his family make use of the schools, the churches, the libraries, the parks, playgrounds and places of amusement, and the trolley and bus lines without stopping to inquire how they came to be located. He and his wife buy the family provisions in the markets which happen to be nearest their home without questioning how those markets came to be so located and whether they should be where they are. Unless some shop comes into the neighborhood and forces the attention of the family, the average citizen accepts the physical arrangement of his town as though it were a fixed condition which he could not change.

We shall see, however, that, in spite of the persistent tendency of streets and boundaries to become permanent, there is a counterbalancing tendency to change which may be turned to useful purpose when citizens recognize their collective responsibility for these community facilities which are not under individual control. We shall see that in every community there is some planning, though it is frequently inadequate and sometimes in the interest of the few. We shall see that every community spends some money for so-called improvements. Whether these improvements really improve the living and working conditions of the people and whether they are economic in the long run depends on whether the community has provided itself with "working drawings" for its future developments to the end that each project shall fit into a comprehensive scheme, that mistakes shall be prevented and unnecessary expense avoided. 
Relation of the Population to the Land.-The health, comfort and safety of human beings in their homes, in their places of business, and in transit on the public highways, depends, in large measure, upon the physical treatment of the land and the structures attached to it. Therefore, the relation of the population to the land is of basic importance in all studies for the improvement of living conditions. There can be no adequate physical treatment of the land which is not the result of intelligent planning.

We have ranged on one side the population with its need for shelter, food, clothing, education, occupation, recreation and means of circulation; on the other, the land with its varying topography, geography, geological composition, natural and artificial vegetation, capable of a wide diversity of uses under differing conditions of temperature and moisture. As the size of the population, particularly its density in close-living communities, tends to develop new uses of the land, much can be learned from reviewing the population changes in the United States since the founding of the Republic. We shall see that, far from being obliged to accept fixed conditions, we are living in the midst of constant change. We have only to take advantage of inevitable changes by directing their character to provide a new order of physical conditions in a comparatively short period of time.

Growth of the Population.-The United States came into existence when the colonists, individually and collectively, were land poor. At the time of the first census in 1790 there were 4.4 persons per square mile of territory. In 1920 , though the area of the continental United States had more than tripled, there were 35.5 persons per square mile. The table below will show the rate at which our vast country is being supplied with inhabitants.

In 1920 the population of the identical area enumerated in 1790 had increased from slightly under four million to slightly over forty million, or from 4.4 persons per square mile to 50.8 persons per square mile. In certain restricted areas of 
the United States the population per square mile has reached an astounding figure. In the IIth ward of Manhattan there were in $1920,533.4$ persons per acre or at the rate of over 340,000 persons per square mile. Indeed the average population per square mile for Greater New York is estimated to be I 7,84I, whereas that of Greater London is only 10,789. The

\section{Continental United States}

Area sq. mile

Year land and water

$1790 \quad \ldots \ldots \ldots \ldots \ldots . . .6$.

1800

$1810 \quad \ldots \ldots \ldots \ldots \ldots$

1820

$1830 \quad \ldots \ldots \ldots \ldots \ldots$

1840

1850

1860

1870

1880

1890

1900

I9IO

1920
892,135

892,135

I, 720,122

$\mathrm{I}, 792,223$

I,792,223

I,792,223

2,997, II

$3,026,789$

$3,026,789$

$3,026,789$

$3,026,789$

$3,026,789$

$3,026,789$

$3,026,789$
Population

3,929,214

$5,308,483$

$7,239,88 \mathrm{I}$

$9,638,453$

I2, 866,020

I $7,069,453$

23,19I, 876

3 I, 443,32 I

$38,558,37 \mathrm{I}$

$50,155,783$

$62,947,714$

$75,974,575$

$91,972,266$

$105,710,620$
Density per 3q. mile

4.4

6.1

4.3

5.5

$7 \cdot 3$

9.7

7.9

10.6

13.0

16.9

21.2

25.6

30.9

35.5

day population of the "loop" district in Chicago is estimated to be 2830 persons per acre or at the rate of I,8I I, 200 persons per square mile, though the loop encloses a little less than one-third of a square mile. But the limit of imagination seems touched when one pictures over 400,000 people daily circulating on an area of 212 acres-a bit of land which in some parts of the country, with hard work, might be expected to support and educate a single family.

The Rate of Growth.-Not only is the situation in which we find ourselves to-day an impressive one because of the existing conditions which we must meet; the succession of changes which has in a century and a third transformed the thirteen States into forty-eight, with additional territorial possessions, and has multiplied the population nearly twenty-seven 
times, has rendered the rate of these changes a formidable factor in any consideration of the relation of the people to the land. Moreover the history of the past century must challenge attention in the consideration of plans for the future.

How many of us realize that in the area enumerated in the first census of 1790 there has been a net gain in population of 872 persons for every day that has elapsed since that count when George Washington was president? Of course the increase has not been distributed exactly in that way. During the first decade to 1800 there was an average increase in this area of only $36 \mathrm{r}$ for each day, whereas in the last decade from 1910 to 1920 there was each day an increase of 1492 . In the remainder of the United States, from nothing in I790, we had in I 920 over sixty million or I $27 \mathrm{I}$ persons for every day since the first census. Taking the present mainland, we have, therefore, a total net increase of nearly 800,000 for each year, or over 2 I00 people for every day since 1790 .

If the territory occupied were smaller the changes would be more apparent; but it must be evident to the most casual reader that a population which has doubled five times in 135 years, or about once in each generation, must require physical provision for habitations alone, which means the occupation of considerable new areas of land each year. A glance at the census changes, counted by generations of thirty years, will, perhaps, indicate the rate of the changes which have occurred

Census Year

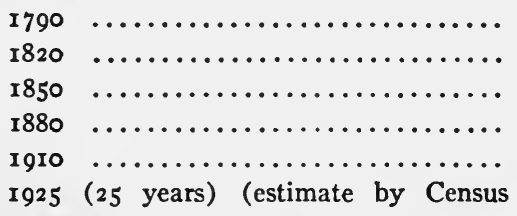

Bureau)
Population

$$
\begin{array}{r}
3,929,214 \\
9,638,453 \\
23,191,876 \\
59,155,783 \\
91,972,266
\end{array}
$$

I $13,493,720$

during the life time of many men and women. The average span of life in Kansas and four other States is over sixty years for women and just under sixty years for men, so that a very 
large number of our people will have witnessed the changes of two of these periods, while a few may have survived thrice thirty years.

Increase in Area of the United States.-The changes in population of the United States have been hardly less remarkable than the changes in its area during the first seventy years of its existence. From a strip along the Atlantic Coast comprising 892,I35 square miles, between 1800 and 1860 its area was practically tripled. To-day there are in the continental United States 3,026,789 square miles. The territorial possessions comprise 7 I6,081 square miles.

As our great population has literally swept across the continent, the center of population has moved westward from a point 23 miles east of Baltimore, Maryland, to a point about ro miles west of Bloomington, Indiana, for the first hundred years moving at a rate varying from 36 to 80 miles a decade. A frontier line a thousand miles wide, advancing across three thousand miles of mountains and plains to spread over two billion acres at a rate which moved the center of population on an average of six miles each year over a period of a hundred years, is a movement of population in volume and rate never before equalled in the world's history.

Increase in Urban and Rural Population.-In this stupendous movement of our people across the country from east to west there have been cross-currents and eddies. In 1890, one hundred years after the first census, there were $62,947,7$ I 4 people in the United States. Of these, 22,298,359 lived in 141 7 cities and towns over 2500 . In 1920, thirty years later, $54,304,603$ people lived in 2787 towns.

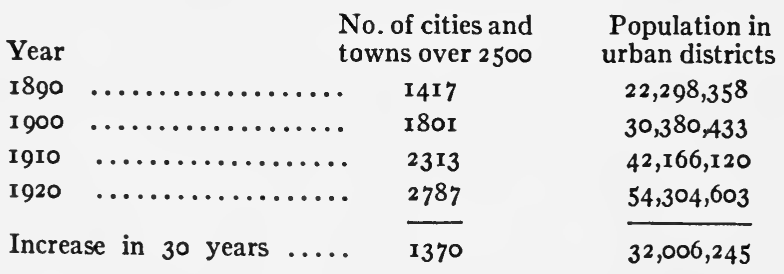


During the same years the rural population of the United States increased from $40,649,355$ to 5 I, 406,017 .

\begin{tabular}{|c|c|c|c|c|c|}
\hline \multirow{2}{*}{ Year } & & \multirow[b]{2}{*}{ Population } & \multicolumn{2}{|c|}{ In towns less than 2500} & \multirow{2}{*}{$\begin{array}{c}\text { Other rural } \\
\text { territory }\end{array}$} \\
\hline & & & Number & Population & \\
\hline I 890 & ...... & $40,649,355$ & 6,400 & $4,757,874$ & $35,89 \mathbf{I}, 38 \mathrm{I}$ \\
\hline I900 & $\ldots \ldots$ & $45,6 \mathrm{I} 4, \mathrm{I} 42$ & 8,900 & $6,301,533$ & $39,312,609$ \\
\hline I9Io & $\ldots \ldots$ & $49,806,146$ & I I, 832 & $8,169,149$ & $4 I, 636,997$ \\
\hline 1920 & $\ldots \ldots$ & $51,406,017$ & I 2,905 & $8,969,24 I$ & $42,436,776$ \\
\hline & & & & & \\
\hline 30 & rs. ... & I0,756,662 & 6,505 & $4,211,267$ & $6,545,395$ \\
\hline
\end{tabular}

In thirty years, a single generation, we have 6500 new towns which are still under 2500 in population. In the same period we have a net increase of 1370 towns, either new, or growing out of the "2500-and-under" class.

The constant increase in the number and size of the towns and cities of America, as well as the steady, though slower, increase in the rural population, presents to this generation a complicated problem in planning.

Dwellings Built in the United States.-A rough gauge of the extent to which planning is needed to take care of our expansion is found in the increase in the number of dwellings required to house our population. To furnish shelter for some $24,000,000$ families there were in the United States in 1920 about 20,000,000 dwellings, including apartment and tenement houses. Of these, nearly 13,000,000 urban families were housed in about nine and one half million dwellings and eleven million farm families were housed in eleven million odd dwellings. In addition to all replacements, therefore, there have been built in the United States during the period from $185^{\circ}$ to 1920 (70 years) over $17,000,000$ dwellings, or at the rate of about 250,000 each year.

Our Land Resources.-The area of land actually occupied for dwellings, industry and commerce is small in proportion to the area used for agricultural, mining and other pursuits. As our population increases we shall be forced to adapt our uses of the land resources of the United States to conform 
to economic principles. Weary and discouraged farmers will no longer be trying in vain to raise profitable crops on land better adapted to forest culture. Land suitable for cattle or sheep grazing will not be rated as wheat or corn land. Water power will be developed in places where it does not interfere with more important recreational or scenic areas. We shall surely come to the day when land is rated by points just as fine stock is judged at a fair. But we shall make further errors if we attempt to confine this rating of land resources to physical characteristics. Dr. Ely has clearly stated the physical, economic and social limitations of land utilization. No matter how fertile a specific piece of land may be, it is useless to grow upon it intensive, perishable crops which cannot be marketed because of lack of transportation or prohibitive cost of transportation. The physical characteristics of land, in spite of the decline of fertility observed under poor farming methods, are much more permanent than the economic characteristics which change from generation to generation and even from year to year. Land which is not profitable to farm, that is, submarginal, when cultivated in competition with fertile, virgin, valley land in a section of cheap labor may prove quite profitable when these conditions become equalized. Land which became unprofitable for general crops in New England at a time when the fertile Mississippi Valley farms could produce large crops at low cost, is being used now for market gardens because its proximity to great numbers of consumers makes intensive cultivation and artificial fertilization profitable.

Opportunity for Intelligent Planning.-Certainly there is wide opportunity for planning new communities as well as for revamping the older settlements to meet modern requirements. The great city population is dependent, not only on the land on which the people live but on the great agricultural areas beyond the city limits. The vast store of natural resources must be utilized for a population, often far distant from the supply. The problem is to find for each period of development the greatest benefit to the people from the intelligent utiliza- 
tion of all of our land resources. Whether we plan well or whether we plan badly, new forest areas are being cut over, new land is being occupied for farms, new water power is being developed, new country highways are being built, new city streets are being laid out, new houses are being constructed, new business blocks, new factories, new schools and new churches are being erected. The question is simply this: Shall our citizens, individually and collectively, neglect to exercise ordinary foresight? Shall we look before we leap, secure technical advice before we move, plan before we build? 



\section{SECTION I}

\section{BEGINNINGS IN AMERICAN PLANNING}

\section{CHAPTER I}

\section{EARLY LAND POLICIES IN LAYOUT}

When we set ourselves to solve any problem in planning for the use and treatment of the land in the United States we find so many conditions which must be accepted or which can be changed only with great difficulty and expense that it seems wise for us to inquire just what these conditions are, how they came to exist and whether the reasons which caused them still hold good.

The settlements of the Anglo-Saxons along the Atlantic seaboard date back but a little more than three hundred years, the occupation of the great Mississippi Valley was almost wholly an achievement of the nineteenth century, whereas the acquirement and development of the Pacific Coast have come within the memory or many now living. The West was peopled in pioneer days very largely by migrations from the Atlantic settlements, which accounts for the fact that many of the customs of the older communities in regard to land layout were transferred to the frontier. Both for its direct survival in the East and for its influence in the West, therefore, a review of the management of land in colonial times will prove valuable.

The early proprietary grants in the New World were of considerable areas, described necessarily "in the large," taking advantage of the coast line and important rivers already mapped and the lines of latitude and longitude. The monarchs of England and their deputies succeeded, indeed, in overlap- 
ping the areas of some of the various grants and charters. The exact area and boundaries of the vast back-country, consisting of hundreds of thousands of acres of close-standing forest, seemed of little importance to the isolated little bands of settlers struggling with small hand tools to clear a few acres of coast land each year.

Boundaries of Early Grants.-Early boundaries were drawn as upon a ten-league canvas. The original charter of the Council of New England was for an area conceived as running from ocean to ocean between the parallels of $40^{\circ}$ and $48^{\circ}$ of latitude. The Virginia grant of 1606 was planned to run into the interior about one hundred miles. The northern boundary of the Maryland grant to Lord Baltimore was described as running along the " $40^{\circ}$ of Northern latitude from the Equinoctial where New England commenced," the southern line was the south bank of the Potomac. In I68I Penn's tract was blocked out roughly from the $40^{\circ}$ to the $43^{\circ}$ of latitude and from the Delaware River $5^{\circ}$ west.

Needless to say, the boundaries of these grants were determined by maps which gave little information concerning topography and hardly foreshadowed the modern contour sheets issued by the United States Geodetic Survey. Most of the early maps were in two dimensions only though the picture maps often indicated hills by little peaked symbols.

Virginia Practice.-While the grants and charters depended largely on map descriptions, the small parcels of land passed on to the individual holders were at first staked out on the ground. But the official surveyor appeared on the scene very early in the history of the Atlantic Coast settlements. In Virginia a long line of respectable, if not eminent, surveyors held office under the King's appointment, and when the charter of William and Mary College was granted the institution was authorized to appoint the surveyors.

A number of questions occur to the inquiring mind. What sort of boundaries did these surveyors run? How were they determined and how were they marked? 
The banks of rivers usually formed the base. The plantations extended ordinarily to low water mark, thus establishing at this early date private ownership of land bordering navigable waters. A line at right angles to the base river line was run for a mile. The most common marks were four blazes on a tree. When the land along the rivers had been appropriated the next tier of farms tended to rectangular boundaries. But Bruce, the historian, records, and later history corroborates, that there was much carelessness in the selection of permanent marks and considerable deviation from true lines, due, doubtless, in part, to the inaccuracy of the instruments and neglect of the narrowing meridians.

When the early surveys were made there was a compelling need for some sort of description which could be used in leases and deeds to determine boundaries; but during the $\mathrm{I} 7$ th century a man was either assigned so large a farm that he was sure to find sufficient arable ground for his various agricultural operations or, as in the case of the closer settlements, he acquired several plots for special purposes though his house might be in the fortified and protected town. But when the smaller plots were divided by inheritance or sale and the larger plantations were cut into rectangles by arbitrary straight lines the inadequacy of the rectangular survey to determine an economic farm became apparent.

New England Practice.-In New England the farms were smaller and the soil was less fertile. Stony hillsides and marshy banks of streams abounded. The light sandy soil, when enriched by the manure of farm animals, made excellent gardens, but the farms, even in the early days of large land supply, tended to small parcels for each individual. This led to what Professor Waugh has called the "help-yourself" method of choosing tracts of land. It is possible, too, that the reputed marked individuality of many of the early Massachusetts settlers had something to do with the fact that "each one chose that tract of land which best suited his judgment and proceeded to build his home upon it." 
In New England the smaller size of the plots and the comparatively easy agreement on boundaries, early made a matter of well-understood record, have led to rather fewer boundary disputes in the North than in the South. In New England, as in Virginia, the lands first chosen lay along the streams and water fronts, but though the shapes of the farms were often most peculiar, the very fact that their selection was based on a rough estimate of their economic use set a precedent which might well have been followed in the areas where farming came later to be much more profitable.

Even in New England, however, the influence of the rectangular survey shows on the maps of fields in the long rows or tiers of farms, sometimes running parallel and sometimes at right angles. We have thus the tendency of the surveyor to lay out land in orderly rectangles, easily surveyed and easily described in dependable records and we have the tendency, running counter to this in the desire of the practical farmer to secure good land and the preference of the townsman to select the location of his home regardless of possible streets. The many excellent colonial homes which still stand in New England bear testimony to the fact that the Pilgrims and their followers chose their building sites well.

The boundaries of the early New England towns, which formed the basic local government units for both village and rural areas, are quite as irregular as the outlines of the private holdings. The persistent tendency of new settlements to break away from the parent stem and form new towns is responsible for the large number of towns which make up the environs of Boston to-day when an earnest effort is being made to bring about some semblance of uniform administration and unified road systems through co-operation and federation of the numerous towns.

The National System of Surveys.-The crazy-quilt map of the New England towns did not penetrate to the great West. Indeed the United States is divided into precise geometric patterns in a way that has affected farms, towns, roads and polit- 
ical administrations. The various efforts during colonial times to extend the rectangular survey of the tiers of farms into a mathematical system came to little; but in the early days of the Republic a national system of land survey and land description was adopted for the vast public lands on which the Government was seeking to place settlers.

Though there is little colonial precedent for the 640-acre section unit, as the early units were usually 50 acres or some multiple of 50 acres, there was excellent colonial precedent for the rectangular survey. The system adopted by the early Congresses was undoubtedly the result of earnest efforts to adopt the best system which could be worked out on the basis of the actual experience of the various colonies. The orderly mind of Jefferson, who was a consistent advocate of the decimal system, can be discerned in the policies adopted. After a number of false starts and much discussion by Washington, Monroe, Jefferson, and other leaders, Congress passed the famous ordinance of 1787 to set up the boundaries of those three new States, the Western, Middle and Eastern, which came to be known as Illinois, Indiana and Ohio. In these outside boundaries the Great Lakes and the Ohio River formed natural water fronts, but the surveyed lines ran with the compass straight from point to point. Within the States the land was to be surveyed by sections of 640 acres (one mile square), six ranges of six sections (making thirty-six in all) to a township. The townships were combined into counties and the counties into the States. Thus came about the units of 640 acres to a section, 320 acres to a half section, 160 acres to a quarter section, 80 to half of a quarter section and 40 to a quarter of a quarter section, which to this day dominate the size and shape of most of the farms of this country, regardless of topography, soil, climate and economic considerations.

In the level alluvial plains the disadvantages of this arbitrary unit which brought about rectangular farms were not so apparent. Even in the hilly country of eastern Ohio the earliest settlers frequently took up enough land to include both 
low and high fields. When the system, including the idea that I60 acres comprised a profitable farm, came to be applied to the western prairies and even to the desert lands, the need for some economic gauge became clear only after tragedies of failure had been multiplied. While some modifying legislation and executive action have mitigated the rigors of the conditions of land settlement, the United States Government, now that its public lands have shrunk to areas mostly too poor for profitable utilization by private owners, is facing the necessity of devising some system of classification which shall take into account the various economic uses to which land may be put.

The adoption by the United States Congress of the rectangular survey developed into a geometric system. We have in operation a system which gives an orderly appearance to the map, which lends itself to accurate description and so tends to security of title, but which, when applied to the laying out of economic farms based on selection of lands suitable for farming operations, utterly fails to meet the strain put upon it. As we shall see later, not only our farm lands, but our city lots and streets have been affected by this arbitrary rectangular survey.

Routes of Roads. Local Connections.-It is a little difficult to distinguish between country roads and town and village streets at a time when the New England Town was simply a territorial and political unit in which little settlements of farmers collected, often placing their homes on one of several or many plots owned by them in the vicinity. Under routes of roads, however, we shall consider only the highways which connected one settlement with another and the through routes of travel which were developed to bind together the English settlements in America.

The local paths or ways in New England, though they may seem crooked as compared with the later mathematical cross hatches of the West, were really attempts to go from one place to another by the shortest feasible routes. The New England coast is composed of bluffs and hills alternating with valleys 
and level marshes bordering meandering streams. Cutting through close-standing timber, skirting swamps and circling hills the routes crossed each other at frequent intervals. At the cross roads of routes connecting towns first settled there grew up other towns. The path which ran from Watertown (founded I630) to Charlestown (founded I629) and connected with Boston (founded 1630 ) by ferry is an illustration of this. It was on this path that Cambridge (Newtowne) was located in I63I and over this way for at least four years, until a second ferry was established, passed all the travel from Cambridge to Boston. This road certainly made as direct a connection between Watertown and Charlestown as the topography and geography of the land would permit, regardless of the compass and the shapes of the farms which were then, or later might be, laid out. To-day, nearly three hundred years after this road was first used by white settlers, the route is closely followed by Mr. Auburn and Cambridge (formerly referred to as the road to the college) streets in Watertown, by Elmwood Avenue, Brattle, Mason and Kirkland Streets in Cambridge, by Washington Street in Somerville and Main Street in Charlestown. The fact that this route now within a distance of less than seven miles bears the names of eight streets in four different towns does not destroy its integrity, although the puzzled motorist may be forgiven if he hesitates uncertainly before the many branching roads which confront him, often unmarked, when he is seeking this direct connection between Watertown and Bunker Hill.

If the farms and houses of these settlements were located, as Professor Waugh suggests, on the "help-yourself method" it would seem as though the roads were laid out on the "gowhere-you-please method." Many main highways in New England to-day are along the exact routes of the daily shortcuts of the Pilgrims as they traveled from settlement to settlement and from farm to farm. This, after all, seems to be a fairly sensible method for the laying out of main highways; but its usefulness is limited by the change in termini of routes 
of travel from generation to generation. The superimposing of several "go-where-you-please" highway systems on the same area does, in the end, tend to create a most confusing network of streets and most remarkable shapes of building lots. Moreover, the changes in vehicular traffic make desirable fewer short turns, more moderate grades and better road beds. Even with these limitations, the extensive use to-day of old paths and ways laid out in the $I 7$ th and 18 th centuries, demonstrates that the New England practice has much to recommend it over the rectangular Western system of roads by which straight routes are seen to lead the longest way round when it is necessary to travel from one corner of the square to the diagonal corner.

At any rate we have as the frame-work on which to build these many survivals in New England of the old paths and ways which connected the early settlements, the first of which was probably the Boston-Plymouth way which was early widened into a regular cart road.

In Virginia a road was built from Jamestown into the interior at a very early date and others followed, but in 1796 , nearly two hundred years after the first Virginia settlement, when Latrobe journeyed into Virginia he had great difficulty in discovering the right road in the confusing network of forest paths. He was riding alone to Richmond, but he states that these bridle paths were unmarked and often branched at remote places away from habitations, which made it impossible to ask the way. As in New England, the Virginia roads were evidently narrow trails broken through the woods, leading from plantation to plantation, well known to the residents but difficult for the stranger to follow.

Main Thoroughfares of Country Travel.-The America which the English settlers found was already covered with Indian trails and buffalo traces which formed the main routes of travel. These Indian trails, narrow and winding, were usually direct enough, considering the face of the country and the entire absence of any method of road building. "Three objects were considered in choosing the routes of Indian trails," 
says George Harris, "first, seclusion; second, directness; and third, a dry path. The trail beaten was seldom over 15 inches wide, it passing to the right or left of trees or over obstacles, around swamps, and occasionally over the peaks of elevations, though it generally ran a little one side of the extreme top, especially in exposed positions. Avoiding open places save in the immediate neighborhood of towns and camps it was universally shaded by forest trees. . . Fallen trees and logs were never removed, the trail was either continued over or took a turn around them. The Indians built no bridges, small streams were forded or crossed on logs, while rivers and lakes were ferried on rafts or in canoes."

These Indian trails were gradually widened into bridle paths and then into cart ways. Many of the existing highways of to-day follow closely the routes of the early paths or ways traveled by the Pilgrims in Massachusetts and the adventurers in Virginia.

The Old Connecticut Path which connected Boston with Albany, is now the route of the Boston and Albany Railroad, and many of the public highways of Massachusetts closely parallel the old routes. The Iroquois trail became the "Great State Road" from Lake Erie to the Hudson River; the Kittonning trail from Philadelphia to the Allegheny was the route of General Forbes's Road from Philadelphia to Fort DuQuesne in $175^{8}$ and formed the basis of the Chambersburg-Pittsburgh Pike which has since been incorporated into the Lincoln Highway. Nemocolin's Path, later Washington and Braddock's Road, became the Cumberland or Old National Road from Cumberland to Uniontown and now forms part of what is known as the Old Trails Road to Wheeling. The Virginia Warrior's Path, which went from Virginia to Kentucky by way of the Shenandoah Valley through the Cumberland Gap, was later made famous by Daniel Boone as his Wilderness Road into the heart of Kentucky.

The Indian trails and buffalo traces of the great Middle West became traveled thoroughfares at a later date. The Lake 


\section{LAND PLANNING IN THE UNITED STATES}

Shore trace to the Niagara River and Fort Detroit ascended the eastern shore of the Niagara River and followed the southern short of Lake Erie, usually on the second rise. It connected Presque Isle, Fort Sandusky and Fort Detroit. The Mahoning trail, which ran from Fort Pitt to Fort Sandusky and the Great Trail from Fort Pitt to Fort Detroit, following the north bank of the Ohio River to the watershed of the Muskingum through Wooster and Fremont, Ohio, formed the stage settings for much that was dramatic in the development of the West. The Great Trail was really the western extension of Nemocolin's Path or Braddock's Road. The Miami Trail became the Old Hamilton and Eaton Roads.

We are here mainly concerned with the methods of choosing routes of roads which have in many cases survived to serve or plague us to-day. We have seen that the conditions to be met in selecting the routes of the earliest trails, paths and ways, are not necessarily the conditions of to-day. We no longer need seclusion, though we do not despise shade. Directness we still desire, but the channels of traffic change with changes in places to which vast numbers of the population are drawn. Dry roads we need, if anything, more than ever, but causeways may be built across swamps, rivers are bridged, and we no longer need to travel so many unnecessary miles to reach our chosen destinations. Moreover, the difference in the character of our vehicles has rendered many of the old steep grades and sharp turns unfitted to the travel of to-day. We can all recall acute-angled turns which are regular death traps for the modern automobile because we travel to-day many roads laid out for other conditions of travel. The cost of rerouting has been one deterrent; the tendency to accept roads as they are has been another; but probably the opposition of owners whose homesteads or other improved property would be injured has been most potent in delaying the replanning of sharp turns which were not necessary because of the topography. Many a traveler from Washington to Frederick has 
had cause to wonder why the sharp and hidden turn at Damascus has not been ironed out of the road.

But these old routes are picturesque and in many respects more practical than the arbitrary squares with no short cuts. The need to modify the routes and grades to meet the conditions of the present is one that is recognized. Particularly on the through routes of travel do we find improvements effected in spite of the difficulties of relocating roads in settled neighborhoods.

The later development of roads through the turnpike company stage to the modern complex network, the growth of railways and their routes will be considered in their proper place. Here we are simply calling attention to the permanent influence which the roads of one, two and three hundred years ago exercise in the city streets and country roads of to-day.

Water and Rail Routes.-Water routes were much used as means of communication during Colonial times, though coastwise travel on the ocean was in the 18 th century precarious because of piracy as well as because of the dreaded storms off Hatteras and other rocky shores. Moreover, the delays in sailing vessels which met contrary winds induced many travelers to use the postroads no matter how rough or difficult they proved.

But the rivers were important routes of communication. Lord Adam Gordon speaks of the boat traffic on the Savannah River between Savannah and Augusta. The Chesapeake Bay, the Delaware, the Susquehanna, the Hudson and many of the New England streams were main water thoroughfares. As the west came into settlement, the river boats on the Mississippi and the Ohio rivers became famous and contributed to our history a picturesque period immortalized by Mark Twain. The Great Lakes were and are great avenues of water traffic. Canals have been dug to supplement the natural waterways and for many years the omnibus rivers and harbors bills of Congress have appropriated considerable sums of money for the development of harbors and waterways. 
The discovery of steam and the perfection of steam railways has covered the map of the United States with a complicated network of routes determined by franchises, sometimes supplemented by land grants and always fixed to the extent of being dependent on rails laid on constructed roadbeds. In many parts of the country a supplementary network of trolley interurban lines has been spread over the landscape, but many of these lines are now abandoned. Taken for what they are worth, with their millions of invested capital, their carrying power of freight and passengers and their existing rails, they add their weight to the physical conditions which we inherit along with the country highways and city streets. They are a part of the planning problem presented to this generation.

\section{SUGGESTED READING}

Richard T. Ely and Edward W. Morehouse, Elements of Land Economics, Macmillan, I924.

Amelia C. Ford, "Colonial Precedents of our National Land System," Bullctin of the University of Wisconsin, No. 352, History Series, Vol. 2, No. 2, pp. 321-478. 1908 .

George Otis Smith, "The Classification of Public Lands," United States Geological Survey, Bulletin 537. I9I3.

P. A. Bruce, An Economic History of Virginia in the Seventeenth Century. Macmillan, I896.

"Short Account of the First Settlement of the Provinces of Virginia, Maryland, New York, New Jersey, and Pensylvania," I630. Reprint by American Geographical Society, 1922.

A. B. Hulbert, Historic Highways of America, I6 vols. Arthur H. Clark Co., 1902-05.

L. W. PAGE, Roads, Paths and Bridges, I9I2. Macmillan.

FRED J. Wood, Turnpikes of New England. Marshall Jones Co., Boston, I9I9.

The Journal of Latrobe, being the notes and sketches of an architect, naturalist and traveler in the United States from 1796 to 1818. Appleton, I905. 


\section{LAYOUTS OF EARLY SETTLEMENTS}

The layouts of early Massachusetts settlements combined the "help-yourself" method with an effort to arrange the farms in orderly tiers. The early plats of Boston show only too clearly the irregular streets of that town, many of which to-day wind their tortuous way between tall buildings of the industrial and commercial sections of the city. The Boston Common, situated as it was on a peninsula connected with the main land by a narrow neck of land, is rather different in character from the commons or squares which were reserved at the cross roads of scores of little villages settled in the $I 7$ th and 18 th centuries and now a part of the metropolitan district of Boston.

There were in the original settlement of Newtowne (now Cambridge) eight little village streets, presumably two rods wide. To-day these streets form the basis of the down-town section of a city of 100,000 people. They form a fairly regular gridiron, modified by the New England tendency to round corners. But the outside connections, consisting of the Watertown-Charlestown road, and later the Lexington and Concord roads, which radiated from the common at various angles, became a part of the street system, so that any semblance to a gridiron system has been entirely lost.

In I794, over I 60 years after the little town was laid out, there were in Cambridge 12 miles of highways; in 1830,38 miles; in 1846 (when Cambridge was incorporated as a city), 5 miles; in 1875,76 miles, and in 1918, 125 miles, albeit cut into 735 official streets, giving an average of six names for each mile of street. The Common, once consisting of 80 acres, 
was reduced in 1724 to 9 acres, but it was 1830 before it was fenced and embellished as a park.

Oliver H. Howe, in an article on Early Town Planning in New England, has remarked on the tendency in the interior settlements in New England to place the church upon a high hill with the homes of the settlers grouped about it. It will be remembered that the early church in the coast town of Plymouth crowns a steep hill and that it combined with the place of worship a means of defense from attack. "It was," comments Mr. Howe, "thus an ark of safety in more than one sense, being a fort as well as a church." In many of the hill towns a single street passed over the hilltop as at Rutland, Massachusetts, or there will be four corners as at Scituate Center or sometimes the meeting of three roads in a triangular common. Mr. Howe sets forth that among the sixty or more hill towns of Massachusetts, Rutland, Shrewsbury, Sharon, Goshen, Princeton, Grafton and Leister may be considered typical. In many, if not most, of these towns a rival center of interest has later developed in the valley through the establishment of water-power mills.

But whether the towns were hill towns or river towns or whether they were cross-roads settlements, in most of them there was some rough rectangular system of streets and building lots. But the rows of ranges which formed the nucleus of many a New England town were the center of a radiating network of roads to reach the increasing settlements in the vicinity, and as the town grew new streets were planned around these irregular highways so that the rectangular rigidity was lost in large measure.

The principles on which most early New England towns were laid out, therefore, might be reduced to the finding of a suitable site for the Meeting House, the Town Hall and the Common and the locating of five or ten short streets, crossing each other at right angles in order to give access to ranges of lots more or less regularly laid out. Converging from the Common would be the roads leading by fairly direct routes to 
the nearest towns in all directions. Of course there were onestreet towns, but quite often in these the highway widened into a narrow Common or parkway.

The Connecticut towns closely resemble the early Massachusetts settlements. Norwich, Wethersfield and Windsor are excellent samples of the rectangular layout. A map of Bristol, Connecticut, in 1776 shows a tendency to lay off land in squares and rectangles in spite of the irregular topography which later was responsible for the development of a street system nearly as irregular as that of Boston. Even in the I 8 th century this map would indicate that it was sometimes necessary to recognize a bluff or steep hill, but the diversions from the direct course and the jogs are all at right or obtuse angles. There are no contour roads and no easy curves for travelers.

In New York, Albany, first settled by the Dutch in 1624 and reported in 1769 by Richard Smith of Burlington, New Jersey, to contain "about 500 Dwelling Houses besides Stores and Out Houses," the streets were considered to be "irregular and badly laid out, some paved and others not, Two or Three are broad and the rest narrow and not straight." Richard Smith evidently believed in broad, straight streets, even when applied to the rugged topography of Albany. In further comment he remarked, "Most of the Buildings are pyramidically shaped like the old Dutch Houses in New York." The first streets laid out closely paralleled the river. A plan of the City of Albany made in 1794 shows some extensions of the streets, but it was not until the National period that the present regular gridiron was developed.

The plan of Williamsburg, Virginia, adopted in I699, while rectangular and formal, presents many features of architectural significance, provides a market square, open spaces and street vistas. The irregular approaches of the Yorktown Road and the road from Queen Mary's Port were turned into a wide formal street which connected two parallel streets on each side of the Capitol grounds. The Capitol fronted down the broad 


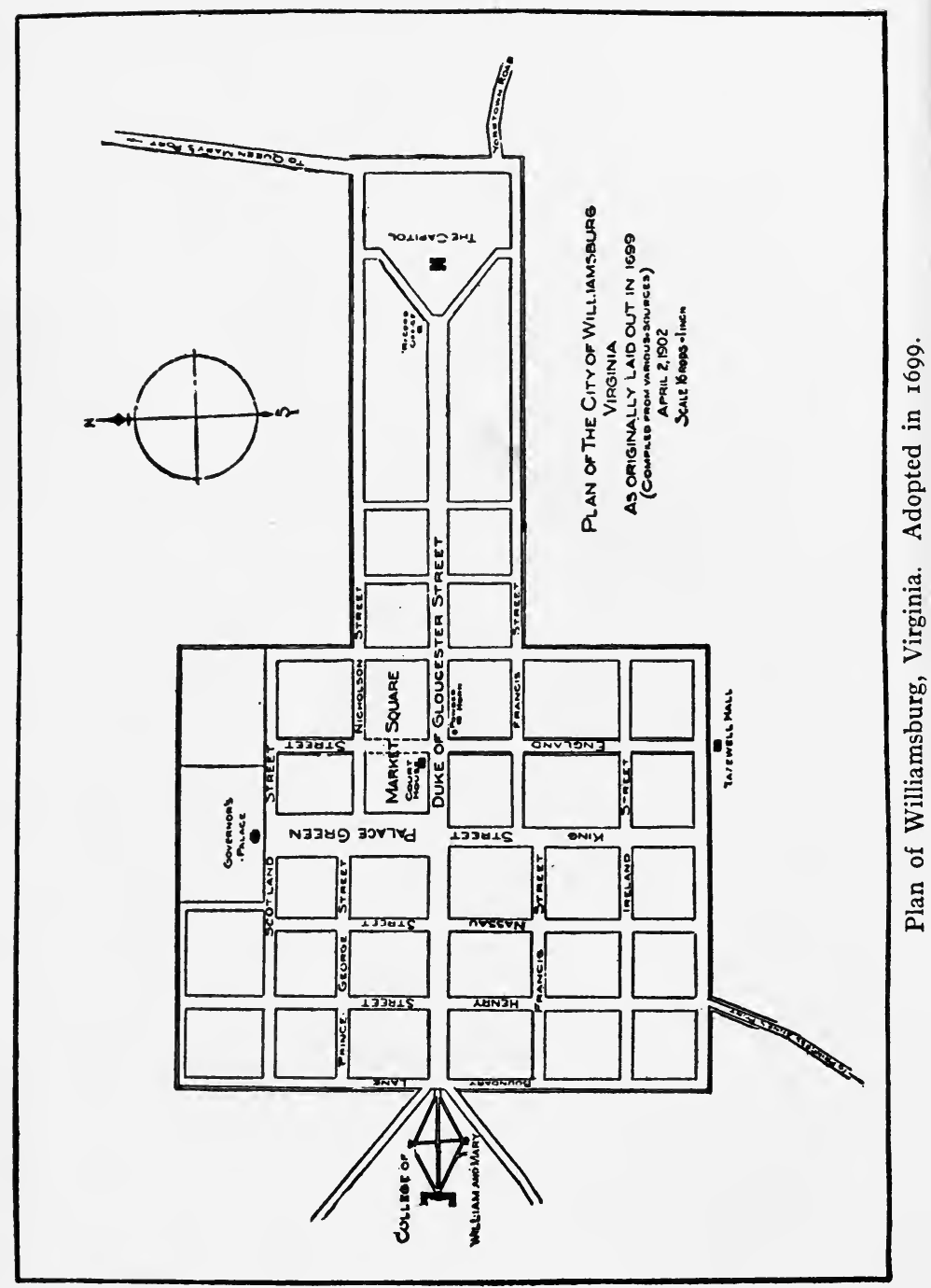


Duke of Gloucester Street formed by the conjunction of two diagonal connecting streets. From the Capitol one could look nearly a mile away to the College of William and Mary which was on the opposite side of town. To the right of the Duke of Gloucester Street was the Market Square, consisting of two city blocks, and at right angles there was the broad Palace Green leading to the Governor's Palace. The irregular road from Princess Anne's Port was turned directly into Henry Street. In Williamsburg the rectangular system was robbed of most of its attendant evils and in a small settlement the plan was surprisingly effective.

Plans for Populous Cities.-The irregular "ways" of Boston, which by 1722 had grown into a system composed of 42 streets, 36 lanes and 22 alleys, were the exception. Most American cities were laid out on some modification of the rectangular plan. If we may believe that the attitude of Lord Adam Gordon who traveled in America in $1764-5$, represented the English public opinion of the time, broad, straight streets were an indication of excellence in layout. He complained that the streets of St. Augustine were too narrow, after the Spanish mode, but admired the line of Palmeto Royal which was planted to mark the boundaries of the town. He considered Savannah extremely well laid out. Of Charlestown he said, "The streets are straight, broad and airy." He forebore to praise the layout of Annapolis, though he considered its situation charming. He contented himself with the comment, "The town is built in an irregular form, the streets generally running diagonally." He particularly admired the "Great and noble city of Philadelphia," the "regularity of its streets, their great breadth and length, their connecting one another all at right angles." He was much impressed with the wheel traffic of the Province of Pennsylvania for which these streets and roads were built. In the entire Province there were said to be twenty thousand wagons. New York he thought much inferior to Philadelphia. He was charmed by Boston, possibly because, as he said, it was more like an English town than any in 
America, and because here the language and manners of the people very much resembled Old England. But it was the spacious, commodious houses, with attached gardens, which attracted his admiration, and of all the remarks he might have made on the street system he contented himself with this single comment, "The main street is two miles long leading from the Gate all the way to the ferry which plies over the Charles River to Charlestown."

In I8I I the entire peninsula of Manhattan was cast into a strait-jacket by the action of the Commissioners, Gouverneur Morris, Simeon de Witt and John Rutherford, when they provided for a few north and south streets cut at right angles by many east and west streets running from the Hudson to the East River. Fortunately Broadway was extended into a single diagonal avenue. In one respect one must recognize the foresight of these gentlemen though they displayed so little skill in laying out the land for its future use. The Commission states in the Report of I8II, "It may be a matter for some merriment that the commissioners have provided space for a greater population than is collected at any spot on this side of China. . . . It is not improbable that considerable numbers may be collected at Haerlem before the high hills to the southward of it shall be built upon as a city, and it is improbable that (for centuries to come) the grounds north of Haerlem flat will be covered with houses." Yet even the space provided by these optimistic gentlemen proved inadequate before the first century had elapsed and exactly III years after this prophecy concerning the occupation of the hills north of Harlem, an unofficial Committee on the Plan of New York and its Environs was organized to seek for the nine million people living in the New York Region a plan for physical development adequate to care for the population which it is predicted will amount to II,500,000 by I 930 and to more than 28,000 ,ooo by the year 2000. The Committee, among other things, is trying to find relief from the evils of that rigid gridiron street system with its spacious blocks which can, in modern 
skyscrapers, house more human beings than can be conducted through the streets in any reasonable time.

From the Atlantic to the Pacific we find these rectangular plans; sometimes, as in Denver, Dallas, Seattle, San Francisco or Madison, Wisconsin, part of the town is laid out diagonally and part straight with the compass. In many cases the radiating connections with other towns have later become city streets and served a good purpose in transporting congested traffic diagonally from the center of town to the outskirts. But the contemplation of the streets of New York, Philadelphia, Baltimore, Cleveland, Indianapolis, Chicago, Omaha and thousands of cities in the United States to-day, and the observance of the problems which have arisen from a highly intensive use of large city blocks as they appear in these cities could lead only to the conclusion that the layout of the streets and blocks should bear a closer relation to the use to which both streets and blocks are to be put. We cannot blame a generation which knew nothing of steel buildings thirty stories high, nothing of steam engines, electric elevators and gasoline automobiles for failing to provide for these modern developments. We have all of these with us to-day, and we have the enormous values which they have brought to certain areas of land. But even after we have given due consideration to the conditions existing we must recognize that there is little evidence that the land used for townsites during the Igth century was surveyed for the purpose of ascertaining an economic layout based on its probable use.

The rigid squares marked on San Francisco's seven hills, regardless of the possibility of travel over streets nearly perpendicular and regardless of the topography of the land thus set off in blocks, stand as a permanent arraignment of the policy of following survey lines for land uses. Every traveler can recall hill cities in which streets are far too steep to be useful and in which the building lots are left in queer shapes as regards the third dimension, however regular they may be in length and breadth. Plastic surgery by the movement of 
tons of earth from one place to another has in many cities reduced picturesque hills and valleys to level monotonous stretches of clay by filling deep holes or slicing off high hilltops.

We have then as a condition with which we are now confronted the prevailing checkerboard plan of towns and cities laid out during the Igth century.

Since the turn of the 2 oth century residential suburbs such as Roland Park, Baltimore, the Country Club District of Kansas City and many of the suburbs of New York, Philadelphia and other populous cities, have been designed by engineers and town planners trained to lay out land with some relation to its use. A few entirely new towns have been built on modern principles, but in the main the city streets and the block shapes and sizes of both town and country have been cast in a mould which it is difficult to remodel.

Moreover, so fixed had become the acceptance of rectangular layouts during the hundred years when they held sway that even to-day it is often difficult to persuade city authorities or private business men that there should be any modification in new towns or subdivisions of the widths and direction of streets with which they are familiar and at the intervals to which they are accustomed.

And when in I9r2, as the result of western observations of Professor Frank A. Waugh, of Massachusetts Agricultural College, Dr. McFarland, President of the American Civic Association, presented to the then Secretary of the Interior certain representations concerning the layout of reclamation towns, the reply of Secretary Fisher reflected a fairly. crystallized sentiment. Said Mr. Fisher: "At present the good, old-fashioned checkerboard system of streets and squares seems to be generally followed. There seems to be a great deal of objection on the part of farmers and settlers to having any other system, even if the only innovation is the introduction of diagonal streets or avenues. They do not wish to conform even with irregular topography. It seems to me, it ought to be possible to do the very best which such conditions permit, 
and I should be glad to have any definite constructive suggestions. I am thoroughly in sympathy with your proposals."

This statement is quoted here to show that we have not only thousands of square miles of rectangularly platted streets, but that we have in this country a psychology or, if one prefers, a public opinion which tends to duplicate and perpetuate the arbitrary square whether or not it is suited to the topography, to the main highways, or to the waterfronts already existing. More than a decade has passed since this pronouncement and the progress of town-building has been such that undoubtedly many of the old prejudices have disappeared. The war shook us out of some ruts. The automobile has given the American public a new standard of roads. Increased travel has given new points of view and new bases of comparison. In collective effort there will always be endless opportunity to make mistakes as well as infinite opportunity to find new methods; but it seems safe to say that technical knowledge has advanced during the first quarter of the twentieth century and public opinion has followed within measurable distance.

Moreover the Reclamation Service has employed a town planner to lay out one of its towns. Most of the original townsite is to be flooded and the new town moved to higher ground, so that over three hundred residences, nearly fifty business houses, together with schools, churches, hospitals, hotels and grain elevators must be moved or wrecked. But the new town is thus assured of an immediate population of some fifteen hundred people. The streets conform to the contour of the rising land, there is a public square around which will be built various public and semi-public buildings, there is a park, an automobile camp, there are adequate school sites and playgrounds, and altogether American Falls, Idaho, bids fair to enjoy the advantages of wise city planning.

Washington, the Capital City.-The most famous plan in America is undoubtedly that of Washington. It was determined by Congress that the United States should build a Federal City within an area not over ten miles square, over 
which it was prescribed, as a sort of guarantee against friction between the Federal government and any possible local government that "Congress shall exercise exclusive legislation in all cases whatsoever."

President Washington chose the exact site of the District of Columbia, drawing the ten miles square on the bias in order to include the exact territory desired, along the stretch of the Potomac River from Alexandria on the Virginia side to a point more than ten miles north, and including within the peak of the diagonal square that part of Rock Creek which now forms the famous park.

The Federal City itself was carved from land owned by nineteen proprietors. In order to lay out the streets and choose the sites of public buildings a French engineer, with a decided appreciation and understanding of fine landscape and fine architecture, was employed to plan the city. Washington, as he was demonstrating at Mount Vernon, believed in inspiring views, excellent planting of trees and shrubs and orderly arrangement of stately buildings. Thomas Jefferson had interested himself in the plans of European capitals and, as shown at Monticello, was himself no mean architect.

Under the supervision of Washington and Jefferson Major L'Enfant was asked to design a city which should provide a proper setting for the seat of the Federal government. He laid out the streets in irregular rectangles and superimposed upon them a diagonal system of avenues which made possible many open spaces in squares, circles and triangles in which are now the monuments and statues which L'Enfant predicted would commemorate the history of the century to come.

The plan of the Federal City reflected the form of government already devised. At one end of Pennsylvania Avenue was the Capitol, or Congress House, the home of the legislative branch. A mile away was the President's House, the home of the executive branch. Along a mall a sixth of a mile wide the government buildings were to be placed as they were needed. The Capitol crowned a considerable hill and four 


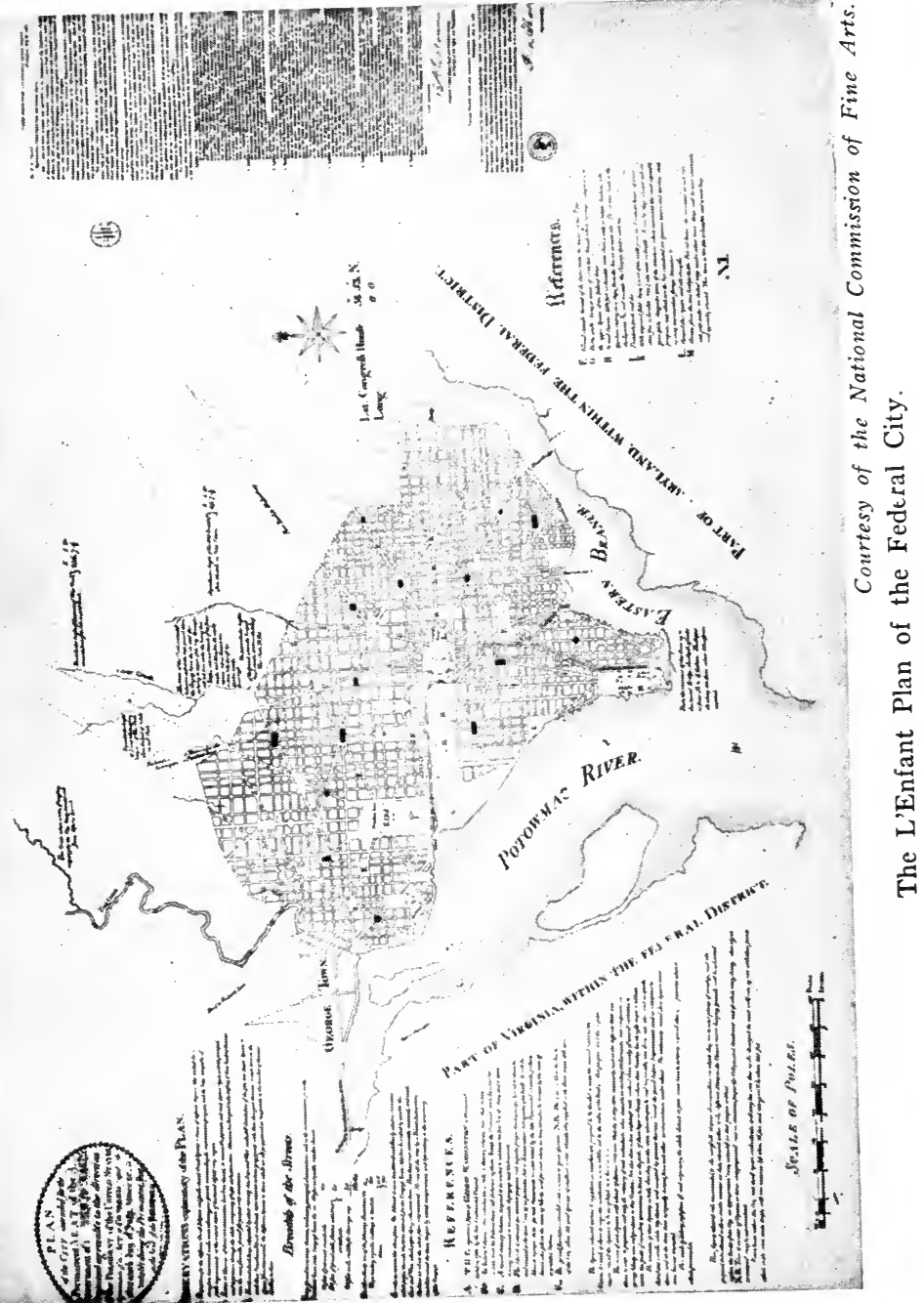


broad diagonal avenues were made to converge to it from eight directions in addition to the streets laid out with the compass.

In so far as the needs of the government could be anticipated, certainly the Plan of Washington conforms to the principles of planning the streets and the spaces between to meet the particular uses to which they are to be put. Except for Capitol Hill the land was fairly level so that there were few natural contours to regard and the combination of the rectangular and diagonal streets does not present as undigested an effect as some of its critics would believe. The Capitol grounds are extensive and stretch across several city blocks. Under the same principle a modern industrial plant is permitted, in certain neighborhoods, to cover an area which includes the streets as well as the blocks of land. The Capitol itself far transcends the original plans and through the contributions of a succession of architects over a long period of years we have fallen heir to a building of unusual majesty, with a beauty much enhanced by the lights which are thrown upon it at night.

The L'Enfant design was not aristocratic. The splendid public buildings were to conform to simple dignified lines and they and their grounds belonged to the people. Most ample provision was made on the many tree-bordered avenues and streets for the sites of pleasant homes. The structure of the L'Enfant Plan, as will be shown later, probably deserves some criticism in the light of the technical knowledge of planning and housing of to-day. But the city has in some respects developed a beauty hardly contemplated by the designers. The Pan American Union, the National Academy of Sciences, the American Red Cross, the Chamber of Commerce of the United States are all housed in stately buildings of great beauty. Rock Creek and Potomac Parks have provided part of a wonderfully lovely frame of green. The trees of Washington cover a multitude of deficiencies in its buildings, which are probably no worse, but certainly no better, than the nineteenth century buildings of other American cities.

The L'Enfant Plan covered only about one tenth of the 
hundred square miles of the original District of Columbia or about one sixth of the present District. Our concern to-day is not so much for the area covered by the Plan as for the much greater area for which there has been, in the true sense of the word, no plan at all. Washington now needs a careful City Planning study which will disclose its present and future needs and which will present a program to direct its future progress along lines worthy of the L'Enfant Plan but based on what we now know of city building. This seems to be assured by the Act of Congress, approved April 30, 1926, reorganizing the National Capital Park Commission, established in 1924, abolishing the Highway Commission by transferring its functions, and creating the National Capital Park and Planning Commission, composed of seven ex officio members and "four eminent citizens well qualified and experienced in city planning." The Commission is charged with the duty of "preparing, developing and maintaining a comprehensive, co-ordinated and consistent plan of the District of Columbia and its environs."

Since the citizens of the forty-eight States, through their representatives in Congress, control the destiny of their Federal City, it is important that the true situation of Washington be understood by the people, for it is inconceivable that the Capital of the United States should not be permitted to receive the technical advice and control which most of the progressive cities of the Union are providing for themselves.

Early Farm Plans.- The arrangement of early farm buildings differed with the individual owners undoubtedly as it does to-day and the arrangement of fields was adapted in some degree certainly to the type of agriculture practiced and the methods then in vogue. But there were certain prevailing arrangements of buildings which are yet recognized as typically New England.

In New England both the climate and the custom dictated attached buildings. Sometimes the sheds, storehouses and barns ran back from the kitchen, sometimes at right angles. 
In the more elaborate and prosperous farms the buildings are frequently set around a quadrangle of which the highway forms the open side. The house usually stands near the road though sometimes there is a deep dooryard in front of it.

In a New Hampshire farm group described by Mr. Arthur Shurtleff, and shown in the accompanying sketch, one could

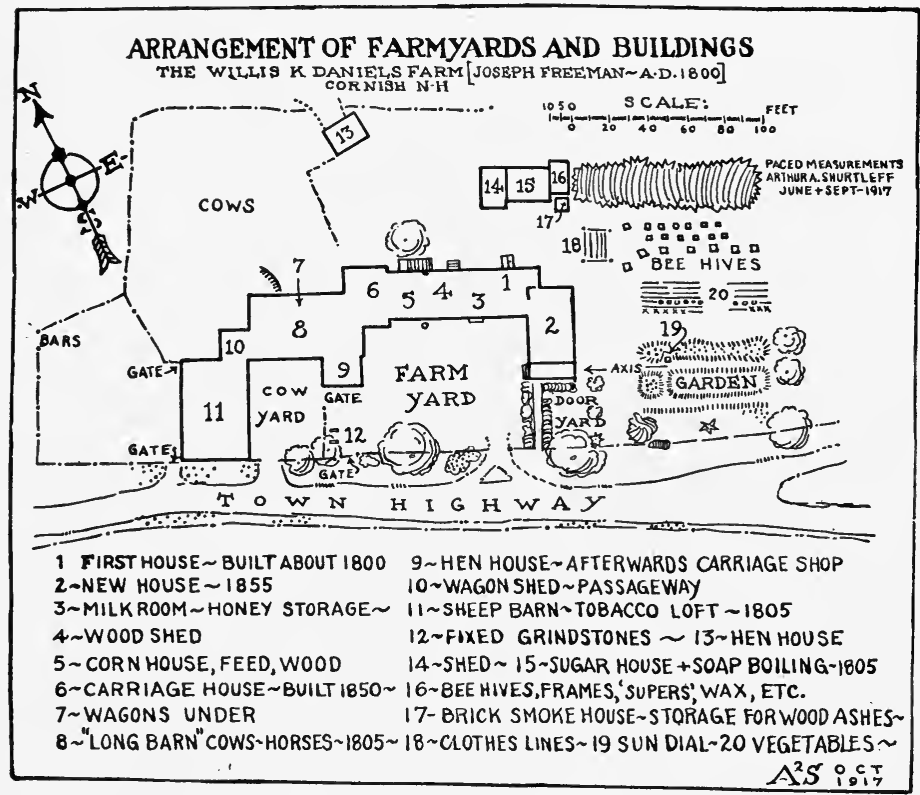

A New Hampshire Farmyard laid out about 1800.

start in the house and walk under cover through the kitchen, the milk house, the woodshed, the corn house, the barn, the hen house, the wagon shed and the sheep barn, the latter standing on the opposite wing of the quadrangle fronting on the highway. There are some scattered buildings, both old and new, but in this arrangement, as in most of the attached groups in New England, there was an orderliness and a formality which a dozen barns, sheds and houses set at various angles, 
of different heights, materials and types could never achieve. The very orderliness of the grouping seems to have stimulated order in the day's work. At any rate, around these New England groups to-day, one sees little discarded machinery, trash and dirt which by tradition may be found on the place of "Farmer Tumbledown."

In Maryland the farm buildings were seldom attached to the house, but around the stone and brick mansions of the eighteenth and nineteenth centuries there are almost invariably well-laid-out and planted house yards. The bank barns, separated by a fence or stone wall from the homeyard, are of excellent proportions and, in the days before dairy cows were treated to steam heat and special grooms, were thought to add warmth by placing the stalls for the horses and cows under the bank with only a sheltered opening to the east or south. It is true that to-day the basement of the bank barn is not considered a sanitary shelter for fine registered stock, or, indeed, any stock, which, like the children of the nation, are believed to need sunshine above ground. No cellar apartments for man or beast!

Many of the old Virginia farms presented charming arrangements of buildings and the climate made possible a growth of vines, shrubs, flowers and trees which helped to bind together the separate buildings. Mount Vernon is perhaps the most famous survival. The industries and the farm operations were housed in a succession of detached buildings arranged in the form of a hollow quadrangle with the wings projecting toward the land approach and the rather long mansion forming the connecting link with its outward front toward the Potomac River. Even the kitchen at Mount Vernon was detached, being connected with the main house by a covered colonnade. Latrobe in his Journal criticizes the land entrance as not impressive because it led past the stables. Comparing in his mind this unpretentious farm with the many elaborate estates of Old England one cannot wonder that an architect would note this as a defect; but after all, the grouping of the buildings, com- 
bined with the lawn, trees, and shrubs, presents to-day a very harmonious appearance.

In the first western farms of Ohio many of the New England customs were transferred, but in general there was a tendency to detached groups of buildings, although the woodshed was frequently attached to the house. But the settling of most of the Great West came later in the century when building standards had declined, when pioneer conditions exerted a heavy economic pressure, and when the public in general had ceased to be discriminating concerning the appearance of houses, barns and utilitarian structures. Many of the early farms and far too many of the recent "improvements" show little regard for well-proportioned buildings, well placed, and often the arrangement ignores the convenience which might be secured for the daily operations.

In California the farms of the early missions and the succeeding settlers have set an example in picturesque arrangement suitable to the climate. Many of the modern groups have followed the old samples. Along the Pacific Coast may be found exceedingly interesting rural groups, though the lack of green ground covering for most of the year presents a strange contrast with the alternating green grass and snow of the New England farms. The landscape, the buildings, the climate, the customs are different from most other parts of the United States, but are none the less satisfactory for that.

\section{SUGGESTED READING}

Oliver H. Howe, "Early Town Planning in New England," in American Architecture, October I3, I920.

Warren H. Manning, "A National Park System," in Parks and Recreation, January-February, I924. (Mr. Manning points out the trend of modern population to the lowlands.)

Arnold Brunner and Charles Downing Lay, Studies for Albany, I9I4. (Contains quotations from Richard Smith's Tour of Four Great Rivers.)

Jown Noles, Remodeling Roanoke, A Report to the Committee on Civic Improvement, I907. (The Plan of the City of Williamsburg, Virginia, as originally laid out in 1699 , compiled from various sources in April, I902, is reproduced in the text.) 
Captain John Bonner, The Town of Boston in New England, I722. "Journal of Lord Adam Gordon," in Travels in the American Colonies, Macmillan, r9I6. (Lord Adam Gordon lived from I690 to I783.) "The Plan of New York and its Environs," Bulletin on The Meeting of May Io, I922, Russell Sage Foundation. (Quotations are made from the statements of the Commissioners of I8II.)

Russell V. Black, "The New American Falls, Idaho-A Town Reborn," in American City, March, 1922, p. 254.

Harlean James, "Our Federal City, a National Symbol," in Review of Reviews, August, 1924, pp. I77-190 inc.

A. A. Shurtleff, "A New England Farm Group of 1805," in Landscape Architecture, October, I9I 7.

Lewis M. Hastings, "The Streets of Cambridge," City of Cambridge, I 92 I.

\section{NOTES}

Page 32. The Committee on the Plan of New York and its Environs consisted of Charles D. Norton, Chairman, Robert W. de Forest, John M. Glenn, Frederic A. Delano, Dwight W. Morrow, Frank L. Polk, Frederick Keppel, Secretary, Flavel Shurtleff, Assistant Secretary. On Mr. Norton's death in I923 Mr. Frederic A. Delano succeeded to the chairmanship. When, Dean Keppel became President of the Carnegie Corporation, Mr. Thomas Adams became General Director of Plans and Surveys for the Committee on the Plan of New York.

Page 35. On receipt of the letter from Secretary Fisher, Dr. McFarland appointed a committee consisting of John Nolen, Cambridge; Frederick Law Olmsted, Jr., Brookline; Frank A. Waugh, Amherst; Harlan P. Kelsey, Salem; and Warren H. Manning, Boston, and these gentlemen rendered a report which set forth some of the controlling principles of town planning as applied to new townsites. 


\title{
SECTION II
}

\section{MODERN CITY PLANNING, ITS AIMS AND ACCOMPLISHMENTS}

\author{
CHAPTER III
}

\section{SHORT HISTORY OF CITY PLANNING IN THE UNITED STATES}

In one sense, ever since cities have been built there has been city planning. Many imperial cities of the ancient world were laid out by engineers with an aim, presumably, of meeting the needs and customs of the civilization then and there in existence. For centuries there have been land boundaries for cultivated fields, roads for travel and land division in cities. Without prejudice to the influence which Syria, Greece, Rome and mediæval Europe have exercised on American cities and without reference to the more easily traceable mark of modern Europe, it is the purpose of this book to discuss the problems of City Planning as they have developed in the United States.

During the three hundred years of occupation of the Atlantic seaboard and the more recent developments of the West, we have been changing the map of the United States by filling it with routes of travel, boundaries, political and physical, and by structures ranging all the way from huge factory plants covering acres to one-room cabins. An effort has been made to sketch an impressionistic picture of how these changes have been effected. But the narrative has been confined to roads and streets and blocks of land with attached buildings, since in the early settlements these made up the structure of town and country. To-day every town and city of any consequence 
must install a long list of utilities which add another element to the tendency of roads and streets to become permanent. Water mains, sewage pipes, storm drains, electric light and telegraph and telephone wires, in conduits or overhead, fire alarms, street lights, gas pipes and other miscellaneous street furniture are carried under or over ground through the public reservations of streets or alleys and from there extend to private premises for inlet or outlet. In the city of New York there is a complicated crosshatch of pipes, conduits and cables which have presented great difficulties to the building of subways because this vast underground system is frequently unmapped. Only in recent years have city officials made and preserved careful maps of all underground installations.

To the picture of what can be seen above ground, therefore, must be added the underground utilities. The modern city needs X-ray photographs as well as air pictures and surface perspectives to give an adequate idea of its physical make-up.

It has been made clear that beyond a superficial and arbitrary plan of streets most of our cities have not been planned in any adequate sort of way. They have met each problem as it arose, separately, and as well as they could, considering the situation in which they found themselves at the time.

During the years, however, there have been several distinct movements which met about the beginning of the twentieth century in a unified effort which in this country we have called City Planning.

The World's Fair and Architecture.-The most dramatic of these movements was inaugurated at the World's Fair in Chicago. This may be said to have constituted the threshold of the architectural approach to City Planning. Just as the Plan for the Federal City in r79I was based in large part upon the architectural effects, the World's Fair in Chicago in I 893 owed its brilliance very largely to the architectural appeal. The real significance of the World's Columbian Exposition, however, is that it started a nation to thinking and acting along new lines. 
Before the World's Fair there had been beautiful and (judged by the period) convenient buildings in the United States, though there had been rather a steady deterioration from the early part of the nineteenth century which may be said to have reached its lowest level sometime in the eighties.

The Colonial public buildings were, on the whole, simple, dignified and suitable to their uses. The old Boston State House, Faneuil Hall, Independence Hall, Fairfax Court House are still copied for their form and proportion. Pohick Church, near Mount Vernon, makes a pleasing picture to-day. The Christopher Wren types of churches give New England a charm which few of her modern buildings can equal.

But throughout the country, as in Washington, such ornate masses as the State, War and Navy Building, the Smithsonian with its tesselated towers, the merely ugly Post Office structure on Pennsylvania Avenue followed the Capitol, the White House and the Treasury.

The early college buildings at Charlottesville and Williamsburg, Virginia, at Williamstown, Massachusetts, at Carlisle, Pennsylvania, at Princeton, Harvard and Yale are notable. But most of the older college campuses are veritable museums of the architectural styles which succeeded each other during the span of the nineteenth century.

In domestic architecture the mansard-roofed monstrosities, the heavy square residences surmounted by cupolas, the pseudoGothic peaked-roofed gables hung with never-melting icicles or cut-paper patterns in wood and trimmed with fancy iron porches, the modifications of mediæval castles with tesselated towers, the merely marvelous mansions of no period and every style, the indiscriminate combination of fake-English timbering and crumbling stucco, the bungalows with heavy overhung roofs like projecting eyebrows, the villas with cornices shaved off like men without hair or eyebrows, the Georgian pillared porticoes thrust in front of utterly inadequate and ill-proportioned structures, the endless repetition of some carpenter's interpretation of Dutch Colonial-all-all may be found in 
any city over one hundred years old and in many young enough to know better.

The World's Fair was staged at a time when the architecture of individual buildings, public and private, had reached its lowest ebb. Any one who does not accept the statement may take an automobile tour through the principal cities of the country and ask the building dates of the good and bad public buildings as judged by the standards of to-day. Such an one will find that good, plain simple buildings are either early nineteenth century or since 1893 . There are few exceptions.

But the most important contribution of the World's Fair in Chicago was not the effect which it exercised in the revival of interest in architecture and the consequent cultivation of discriminating appreciation of good building, though this was one of its valued results. The lesson of the World's Fair is to be found in the æsthetic and spiritual effect which, it was learned, could be secured by comprehensive planning for groups of buildings tied together with a landscaping which included sheets of water, trees, shrubs and flowers arranged by artists.

Co-operation of Architects, Landscape Architects and Engineers.-For the first time in this country, committees of architects, landscape architects and engineers co-operated to produce a marvelous spectacle which touched the dormant emotions of many Americans and so left a profound effect upon the building of cities. The canal that was induced to run down the Midway Plaisance, the buildings (save one which like some ruin of a past civilization still stands in Jackson Park), the lights, the gaiety, the exhibitions of arts and industries, and the less-worthy country-fair side-shows have all disappeared. But the World's Columbian Exposition of I 893 started a movement which is only now, after more than thirty years, well under way and like

"The hand that rounded Peter's Dome And groined the aisles of Christian Rome,

$\mathrm{He}$ builded better than he knew,

The conscious stone to beauty grew." 
Landscape Design.-But long before the World's Fair was ever thought of, there was another movement, small and weak at first, but during the latter half of the nineteenth century gathering strength and wide influence. That was the growing interest of the American people in their native landscape anc in gardening which, in congested cities, created a demand for parks. Like most such movements the interest was not entirely spontaneous. It was fostered by leaders.

It was natural, during the years of conquering the forest in order to make way for homes and farms and under trying pioneer conditions that gardens should have been few and that there should have been little consciousness of a need for parks. Moreover the conception of the public park, as we now know it, was not yet formed. There had been parks surrounding the English manor houses and the French castles. There was the Common which had been transferred to New England from Old England, sometimes used as a pasture for cows and sheep, later developed into a sort of parade and often the center of the market place.

In two of our early cities we have the French "place." A map of the "Plan et Projet de la Nouvelle Orleans," dated August 9th, I763, shows within the fortifications, in the exact center of the waterfront of the "Fleure St. Louis," now the Mississippi, an open square marked "Place d'Armes," and a map of "Saint Louis des Illinois" shows a similar fortification in size and shape with a similar open square in the center of the river front called a "Place." In St. Louis a "commons". was set aside as a pasture for the live stock of the settlers and a "common field," known as "La Grande Prairie" was selected and divided into strips nearly $192 \mathrm{I} / 2$ feet wide by $\mathrm{I} 70$ feet long and assigned to the settlers for cultivation-the rectangular field even at this early date.

The open squares in Penn's Plan of Philadelphia approach more nearly the democratic small park of to-day and though much of the open space of the Washington Plan was in the nature of public grounds around public buildings or provided 
as a setting for monuments, yet there were provided small open spaces for the use of the public.

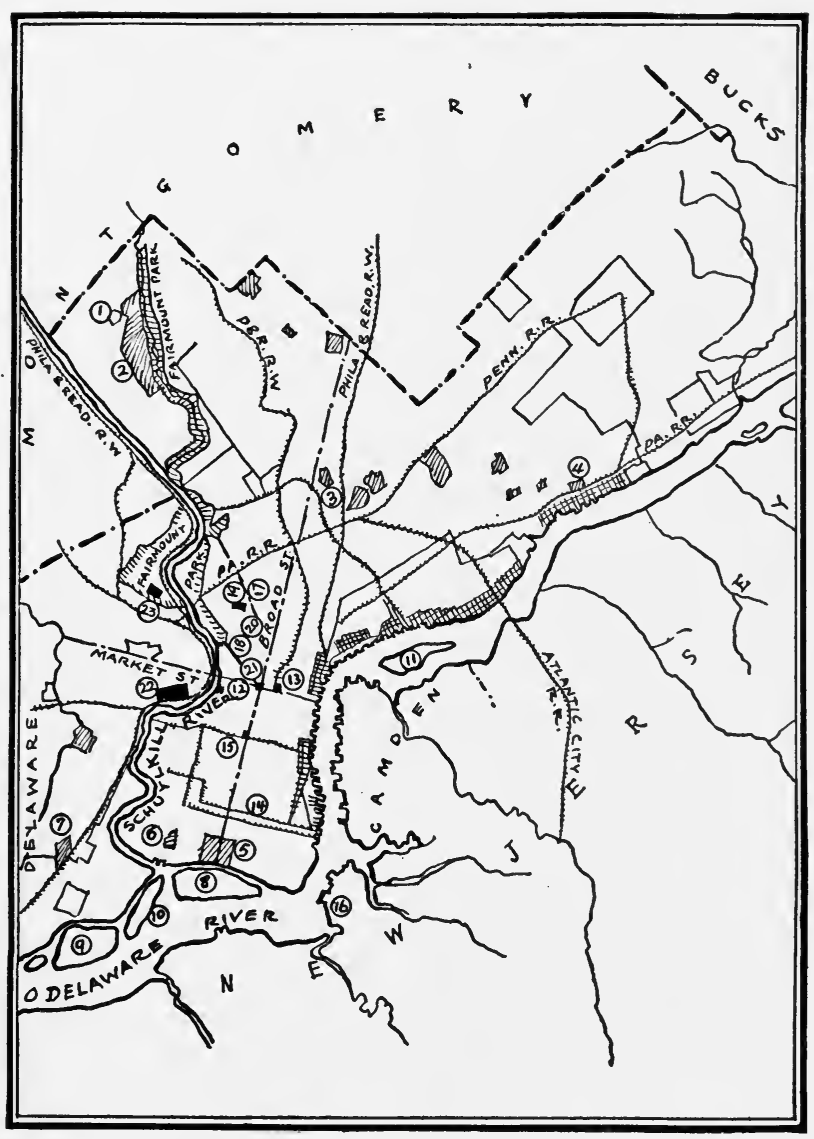

Philadelphia

2-7, I7, I8 Parks, Boulevards, and Streets; 9-II Islands; 8, I2-I5, I9-23 Places of Interest.

The conception of the great country park for the people was yet to come.

Agricultural Societies were formed in South Carolina, Penn- 
sylvania and Massachusetts toward the end of the eighteenth century, and these gave attention "to the improvement of home grounds, to street-tree planting, and to the preservation and reproduction of the forest." Then came the horticultural societies, organized mainly to increase scientific knowledge but incidentally throwing their influence toward more and larger open spaces for the public.

After the Revolution garden books for America began to displace the English texts which had never given information entirely useful in American soil and climate and gradually through the horticultural literature of the United States, landscape gardening began to emerge. Also there was gradually coming into existence a new conception of public parks, stimulated by Andrew Jackson Downing who in I84I published a treatise on the "Theory and Practice of Landscape Gardening," and in 1849 wrote for the Horticulturist a series of letters on public parks.

Mr. Downing thought the proposed park for New York City of 160 acres "altogether too scant, and argued that 500 acres between 39 th street and Harlem was the smallest space that should be reserved for the wants of the city, since no areas less than this could furnish a rural landscape or offer space enough for broad reaches of park land with a real feeling of the breadth and beauty of green fields, and the perfume and freshness of nature."

It was Downing who developed further the park idea in Washington. In 1850 he was asked to confer with President Fillmore with reference to the laying out of the grounds in the vicinity of the Capitol. Before his death he had spent a year and a half on designs. In $185^{I}$ in his report to the President he presented what must then have been a new idea for a park. Said he,

"A National Park, laid out and planted in a thorough manner, would exercise as much influence on the public taste as Mount Auburn Cemetery near Boston has done. Though only twenty years have elapsed since that spot was laid out, the lesson there taught has 
been so largely influential that at the present moment the United States, while they have no public parks, are acknowledged to possess the finest rural cemeteries in the world. The Public Grounds at Washington, treated in the manner I have suggested, would undoubtedly become a public school of instruction in every thing that relates to the tasteful arrangements of parks and ground and the growth and culture of trees, while they would serve more than anything else that could be devised to embellish and give interest to the Capital. The straight lines and broad avenues of the streets of Washington would be pleasantly relieved and contrasted by the beauty of curved lines and natural groups of trees in the various parks. By its numerous public buildings and broad avenues, Washington will one day command the attention of every stranger, and if its unimproved public grounds are tastefully improved they will form the most perfect background or setting to the city, concealing many of its defects and heightening all its beauties."

The ellipse of to-day was foreseen by Downing as a "circular carriage drive forty feet wide and nearly a mile long, shaded by an avenue of elms," surrounding the parade. "I propose," said he, "to keep the large area of this ground open as a space for parade or military reviews, as well as public festivities or celebrations."

Here was a new conception of public parks which had grown out of the horticultural or landscape gardening movement. Mr. Manning mentions in addition to the horticultural magazines under the direction of such men as Downing, Thomas Meehan and C. M. Hovey, the great influence wielded by such writers as Bryant, Emerson and Thoreau. "In I857," states Mr. Manning, "Central Park and the first Park Commission were established in New York. Downing, by his writing and work, initiated the movement that led to the acquirement of Central Park, but its plan was made and executed by Frederick Law Olmsted and Calvert Vaux. It was the first public park, as distinguished from the smaller and simpler Common, or the great wild park 'reservations' of recent days."

Mr. Manning continues, "It was reserved for Mr. Olmsted to make, in 1885 , the greatest and most distinctively American advance in city and town planning in his design for the Park 


\section{2 \\ LAND PLANNING IN THE UNITED STATES}

System of Boston, to be followed, in 1893 , by the still larger conception of Mr. Charles Eliot in his report upon a Metropolitan Park system around the same city." It måy be remarked in passing that when young Charles Eliot settled down, after his Harvard course and a visit to Europe, to study landscape architecture, no college in America offered courses leading to a degree in this subject. Indeed, it is said that on Henry V. Hubbard, now Professor of Landscape Architecture at Harvard University, was conferred the first degree in Landscape Architecture in America, and this degree was conferred after the World's Fair.

From this it may be argued that at the time of the preparation for the Chicago Fair landscape architects were few in the United States and there was no recognized school for training men and women for this profession. Fortunately, however, Frederick Law Olmsted was invited to participate with the architects and engineers in designing the Exposition. And so it came about that this movement in landscape design which had already influenced an embryonic public-park sentiment and had flowered not only in Boston and New York, but in Brooklyn, Buffalo, Chicago, Omaha, San Francisco and many other cities, received a further impetus. Indeed the high development of the public parks of Chicago made possible the natural setting on the lakeside for the scene which was composed.

Centennial Celebration of Establishment of Federal City.-Following the World's Fair both public and domestic architecture and public and private landscape architecture were stimulated. In 1900 there was held in Washington a centennial celebration of the Federal City as the seat of Government and in that year Senator McMillan of Michigan succeeded in securing the services of Daniel H. Burnham, architect of Chicago, who had acted as chairman of the World's Fair Committee, Augustus Saint Gaudens, sculptor, Charles F. McKim, architect of New York, and Frederick Law Olmsted, Jr., landscape architect, to act as a Park Commission. 
The Park Report of I90I which was prepared by this illustrious quartette was a landmark in planning for the use of land suitable for land areas. The preservation of the valleys and streams flowing into Rock Creek was urged, sites for open spaces in yet unoccupied territory were selected and the outline was presented for a comprehensive park system in the Federal City. Unfortunately many of the recommendations of this Commission have been neglected and some of the areas have been utterly destroyed by the removal of the trees and the filling of the stream beds and so permanently lost to the park system. It is a matter for regret that of fifty-three park areas recommended by the McMillan Park Commission in rgor, only six had been acquired up to r 924 .

As a rather definite result of the work of the Park Commission of 1901, a National Commission of Fine Arts was authorized by Congress, and in r 910 President Taft appointed on this Commission Mr. Daniel H. Burnham, who had served as Chairman of the World's Fair Committee and of the McMillan Park Commission. For the third time Mr. Burnham served as chairman of a committee which was to make a contribution to American city building and for the third time an Olmsted served with him, the elder Olmsted in Chicago and the son in the two Washington assignments. The National Commission of Fine Arts, under the present chairmanship of Charles Moore, who had served as secretary of the Park Commission and as a member of the Fine Arts Commission, stands as a protection of the art and architecture of the public monuments and buildings in the District of Columbia.

It is interesting that the trend of thought at that period turned rather definitely to sculpture and architecture as the first expression of the movement to protect the development of the Federal City. Not until r924 was a permanent Capital Park Commission created, authorized to receive appropriations and purchase land to extend the park system of the District of Columbia, and not until 1926 was a permanent planning commission set up. 
Professional Organizations of Architects and Landscape Architects. - The American Institute of Architects has been in existence since I857. Ten years later the New York chapter was formed. Philadelphia and Illinois organized chapters in 1869 , Baltimore, Boston and Cincinnati in 1870 . But it was not until the nineties that chapters began to multiply. In I9I3 the Journal of the American Institute of Architects was established and has since been issued monthly. The Journal has devoted space to City Planning projects and has aided in the forming of City Planning ideals.

In I9I 7, the Committee on Town Planning of the American Institute of Architects, under the chairmanship of George B. Ford, published a two-hundred page volume on "City Planning Progress in the United States," a report "on what has been accomplished or is projected in city planning in all the cities in the United States of over 25,000 inhabitants, and in a few cities and towns with a smaller population where the work is of special interest." There is still a large demand for the book though, unfortunately, it is out of print. It appeared at a time when the information presented was of great value to the officials and civic leaders who were endeavoring to promote City Planning in their home towns; for there is nothing more persuasive to the average American voter than precedent. If some other town has tried it first the voter is apt to conclude that the home town might survive the experiment. The book was not copyrighted. The material was made available for quotation in whole or in part and when possible photographs were furnished for illustration. The publication was a service at the time of its issue and it will remain a volume of historical interest in the development of City Planning in the United States.

The American Institute of Architects to-day has a Committee on Community Planning and a Committee on the Federal City. Mr. Clarence S. Stein, then Chairman of the Committee on Community Planning, defined Community Planning as "not merely the physical layout of streets, avenues, 
blocks and traffic arteries, but the whole environment, including the work, the housing, the recreation, the customs and habits of the people who make up the community." Mr. Horace W. Peaslee, Chairman of the Committee on the Federal City, has taken up the fight to secure a comprehensive plan for Washington, which, he says, "stands to-day with as fine a park plan and scheme for public buildings as has been produced; but it stands without any general plan of co-ordinated street and park systems, of city and country connections, of school and playground reservations, of traffic and industry problems, of that broad study by specialists which every city of consequence requires as a matter of course."

The American Society of Landscape Architects.When Mr. Warren H. Manning first proposed the organization of the landscape architects in the United States, Mr. Charles Eliot advised rather a combined membership of lay and professional men and women. His advice was followed in the organization of The Park and Outdoor Art Association in 1897. But two years later the American Society of Landscape Architects was formed with ten members. In I9I6 the Society was incorporated and in 1924 it had grown to 165 members. The Society has issued a definition of landscape architecture, and a description of the functions of those who practice it.

"Landscape Architecture is the art of fitting land for human use and enjoyment.

"The Landscape Architect designs and advises regarding the arrangement, and directs the development, of land and the objects upon it in connection with private grounds and gardens, institutions, public parks, playgrounds and squares, cemeteries, streets and parkways, residential communities, and problems of city and regional planning."

In r9ro Landscape Architecture, a quarterly, was established under the editorship of Charles Downing Lay, Henry Vincent Hubbard and Robert Wheelwright, as the official organ of the American Society of Landscape Architects.

Through the Journal and through resolutions adopted at 
conferences the Society has exercised an important influence on many problems of City Planning. It "urges on all citizens, whether active in municipal affairs or not, the importance of proper planning in the creation of new streets and other open spaces and in addition to existing ones. The future convenience and efficiency of village or city for business, recreation or residence, as well as its possibilities of beauty are in proportion to the forethought expended on its plan."

In the years since the World's Fair, particularly, these two professional groups through their committees and publications and through the association of their members on specific projects have helped to do the work of planning cities and towns and so have contributed to the development of the subject itself.

Municipal Engineering.-While American cities had been submerged with freakish architecture and had been rather slow to make full use of the native landscape in parks and open spaces, they made fairly good headway in municipal engineering. Water supplies, gas works, electric plants for light and power, street railways, municipal sanitation gave to the larger cities comforts and conveniences yet unknown to many of the more picturesque cities and towns of Europe. These municipal engineering sciences which developed to so high a degree during the latter part of the nineteenth century made a worthy, if incomplete, contribution to the building and maintaining of cities. Engineering, however, until after the World's Fair, and sometimes since, was frequently not combined with architectural design nor accompanied by landscaping which would produce a unified appearance and give distinction to our cities.

If many of the engineers were rather free in expressing their scorn of the merely beautiful they often were unconsciously contributing to the demand for more æsthetic development by their disregard of appearance in favor of supposed utility. But the architects and landscape architects needed some of the technique of the engineers. In recent years we are coming to see that a city is not built by one profession alone. Engineers 
and landscape designers are combining to make boulevards, parkways and residence streets convenient for traffic and beautiful with grass and tree borders. Engineers and architects collaborate to make bridges both useful and beautiful. Architects and landscape designers contribute to the beauty of public buildings set in appropriate public grounds. All are needed in the building of cities.

But it is in the field of utilities that the greatest contribution has been made to the development of the modern city. The need for co-ordinating distributing mains and pipes for water supply to public and private property with the street system is obvious. The proper care of the sewage system and the provision for carrying off storm waters is absolutely dependent upon the street system. It was not so early recognized that the water system from its source, protected by intelligent forestry, with proper conservation of stream flow in tributaries to the main source, with the storage reservoirs and conduits often served the double purpose of providing water for a vast city and also yielding sites for pleasure boulevards and recreation areas.

Water companies, privately operated and publicly controlled, invest new capital in extensions only after the most careful survey of the trend of population, the character of residential, commercial and industrial developments. Telephone companies make equally thorough surveys before investing capital in extensions of service and, because of the centralized management the telephone companies have perfected their methods of securing information which will guide their policies in local communities.

Municipalities may learn much of value from the methods of engineers in surveying the field for installation or extension of water and telephone service. Water and sewage engineers, public and private, electrical engineers and street railway engineers have thus made substantial contributions to the field of city planning and to the cause of planning based on accurate surveys of existing conditions and future trends. 
The effect of street railway routes, subways, surface lines and elevated roads, upon the street system and upon the areas of development is profound. Great sections of cities have been made and marred by street railways and the results will live long after street railways have become as obsolete as the muledrawn street car.

All of these subjects will be considered in their proper place in the city plan. The effect and interdependence of engineering methods, as worked out in these different utilities and public works, upon the street system and the general plan of a city is quite apparent. It is useless to try to distribute impartial credit to the architects, the landscape architects, and the engineers for their several services in establishing the importance of planning ahead, of securing surveys of basic needs and probable future developments. It is a fact that each profession has contributed much to the cause of city and country building and that the association of the three professions in close collaboration promises great achlevements for the future.

Mr. Nelson P. Lewis dedicated his book on "The Planning of the Modern City" to the "municipal engineers of the United States, the first men on the ground in city planning as in city building in the hope that it may help them to realize their responsibilities and opportunities in determining the manner in which cities will develop."

The American Society of Civil Engineers has now created a City Planning Division which offers stimulating programs. The late Nelson P. Lewis was succeeded as Chairman of the Executive Committee by Morris Knowles with Mr. Charles B. Ball as Secretary.

Housing Reform.-Of the movements which have left their impress on American cities and have now come to be incorporated, in part, at least, in the subject of city planning, the movement for housing reform plays an important part. The United States, in spite of its democratic experiment in politics, followed the old-world example in permitting slums to grow up 
in towns and cities. Baltimore, Chicago, New York and Philadelphia are still struggling with housing problems which began to develop early in their history. Congestion in the larger cities intensified the hardships of the living and working conditions of the lower-income groups; but unsanitary homes were not, and are not, confined to urban groups. Housing in rural neighborhoods has frequently become a menace to health. The real trouble came from a lack of social standards. Until recent years it was supposed by most people that slums were deplorable but inevitable; that some poor unfortunates must live in tumble-down shacks; that wretchedness, poverty and disease were a cause and not a result of bad living conditions.

But the ignorance of social laws cannot be loaded with all the blame. At the time the world heard that famous shot fired at Lexington, sanitation for the prosperous was in a very backward state. Liberty, equality, fraternity were new and magic words but they did not as yet compass for any of our citizens the porcelain bath tub, the white enameled kitchen sink, the spouting jets of hot and cold water, the cellar heating plant which turns winter into balmy spring (when it does not produce an oppressive tropical atmosphere), the metal window and door screens which form a barrier to the effective distribution of entire colonies of germs by industrious flies and mosquitoes.

The plain fact of the matter is that the people who lived in America during the early days of the Republic, like those in European countries, were ignorant of how to house and care for human beings-rich or poor. What comfort there was in the extremely æsthetic homes of the prosperous folk of New England, New York, Pennsylvania, Maryland and Virginia was due to the personal service of domestic employes or slaves. No one thought or talked of standards of living conditions which would provide clean, comfortable homes for all. How could they, when the comfort of the few was dependent on the service of the many? Politically our ancestors were feeling their way to a modified democracy but neither their science, 
their philosophy nor their economy was broad enough to lead them to a realization of the importance of safe living conditions for the entire community including every man, woman, child and beast.

The tenements which grew up in the slums of New York had become a serious menace to the health and morals of the city before they were recognized as problems. The first legislative commission appointed in 1857 to examine into the condition of the "tenant houses" in New York and Brooklyn disclosed some of the evils which had resulted from the size and shape of New York's blocks, the change in occupancy occasioned by the onward push of business with the consequent abandonment of residence neighborhoods by the prosperous, by the desire for gain unchecked by human responsibility on the part of owners and by the economic pressure of poverty on the part of the tenants.

"There were," wrote Mrs. Wood, "no restrictions as to light, air, water and sanitary conveniences, repairs or occupancy, except a few weak provisions in the interest of fire protection." The report of the commission of 1857 revealed unspeakable conditions. After recounting the fearful situation in houses where five families of twenty persons of both sexes and all ages occupied a single $12 \times 12$ room; the report concluded that the main needs were air, water, room, light, cleanliness, and plan. The commission probably did not use plan in the modern sense of the word when employed in city planning but the writers most evidently did mean thinking ahead and making provision to prevent tenement house evils by better placing and planning of houses.

Plumbing, stationary bath tubs and running hot water are comparatively recent acquisitions for any of our citizens; but the unrestrained overcrowding of rooms with absolute lack of privacy could not fail to promote a moral laxity and subversion of all civilized standards of living which have been built up through centuries at such cost of striving and self-denial. The only wonder is that clean, self-respecting human beings 
could ever have emerged from such unpromising dens of filth and iniquity. The pillars of democracy do not find firm foundations in such tenements.

The commission recommended a prohibition against renting underground cellars as tenements, additional fire safeguards in the building of halls and stairs and certain restrictions on the use of rooms.

But for all these obvious recommendations the death rate of 32.7 per 1000 of 1856 became in $1865,35.32$. Such a death rate, gaining progressively, threatened the entire community. The Council of Hygiene and Public Health of the Citizens' Association of New York made a comprehensive investigation. At this date there were 15,309 tenement houses in a population of 480,000 and 15,000 people were still living in cellars. Some of the cellars were below the sea level and had water constantly standing in them. There was yet little indoor plumbing (and that kept in poor repair) and there were many filthy back-yard menaces to health and decency.

By this date, too, the housing evils were extending upward. Many of the tenements were seven and eight stories high. Mrs. Wood describes the famous Rookery "which consisted of a front, middle and rear building, completely covering the lot except that between the front and the middle buildings was a space of six feet and between the middle and rear buildings a space of one foot." "Gotham Court was a five-story structure $34 \times 234$ feet, one side bounded by a seven foot alley with a high building opposite. One short end was contiguous to the blank wall of another building. The other short end faced on Cherry Street. Each apartment consisted of two rooms, one dark. The entrances were from alleys." Toilets for all the apartments were in the cellar and the stench was said to penetrate the lower stories.

In a block of a size and shape suited to high apartment buildings it would not have been possible for a single building to be 234 feet long or for a lot to accommodate three separate buildings such as the Rookery. Already lack of 
intelligent planning in the layout of the land for its uses and of intelligent replanning for changed uses was permitting a sordid congestion which lack of social standards alone could hardly have brought about.

The terrible tenements of New York, Baltimore, Philadelphia, Chicago, Saint Louis and other typical American cities came to be a dramatic challenge to the old theory that owners of land might do what they pleased with their own property. That theory has been utterly exploded beyond hope of revival. The constitutional right of the enjoyment of private property has been gradually cleansed of the clogging theories which would permit exploitation of unfortunate human beings. We have learned that some uses of land and buildings infringe upon the enjoyment of neighboring owners in their land and buildings. In all civilized society there is a changing balance between the individual rights and the community rights. Paradoxical as it may seem the result of restricting all owners in the uses of their land and buildings is to give all owners larger enjoyment of that land and buildings however much it may limit speculation in this necessity of life.

We have come to recognize that for mere self-preservation, even if we entertained no altruistic responsibility for our lessfortunate neighbors, we cannot afford to permit in our cities centers of filth, disease and immorality which threaten the entire community. Enlightened self-interest would dictate a control of the use of land and restrictions in plan and construction of buildings if there were no other reasons. Fortunately the great army of public-spirited citizens, lay and professional, who have dedicated their services to the relief of human suffering, have proved to be the pioneers in the movement for democratic community building.

Reforms move slowly but progress can be measured. Compare the restrictions which seemed possible in 1857 with the restrictions possible and in force in 1925 . The upward trend of housing standards is easily established.

In New York, following the first survey of tenements, the 
Citizens' Association succeeded in establishing the Board of Health in 1866 and in securing the passage of the first tenement house law in 1867 . In 1884 the Governor appointed another Commission "to investigate the character and condition of tenement houses in New York and report to the legislature, and as a result of this report came the tenement house law of r 887 with its requirement that running water be placed on each floor. It is difficult for this generation to put itself in the attitude of mind to accept the opinion which was held by many good citizens in 1887 and which led to the fight against this law in the courts. The Court of Common Pleas upheld the contention that the law was unconstitutional and it was not until 1895 that the Court of Appeals reversed this decision and so made it possible to enforce the law requiring cold running water on each floor of tenement houses.

This law of 1887 set another important precedent upon which modern zoning laws have based their regulation of the percentage of the lot permitted to be covered by buildings. By this law $65 \%$ was established as a maximum proportion of an interior lot which buildings erected in the future might cover. But the law was more honored in the breach than in the observance and an amendment which permitted the Board of Health to make exceptions rendered the law practically useless except for the publicity given to the idea.

Jacob Riis in his book, How the Other Half Lives, acquainted the American people with the atrocious tenement houses of New York and with the fight for the park at Mulberry Bend. The tenement house commissions of 1894 and of 1900 each made some progress. But New York still harbors dark rooms, occupied cellars in old houses, basement apartments, semidark rooms, and unsanitary toilets shared by several families.

Housing congestion developed more slowly and later in other cities but Washington, Boston, San Francisco, Baltimore, Richmond, Chicago, Saint Louis, Philadelphia, Cincinnati, Providence, Columbus, Grand Rapids and Minneapolis have all discovered unsanitary housing conditions which they are seek- 
ing to eradicate from their communities. Many proposed remedies are at best only palliatives. In most cities one of the causes of unsanitary housing was the existence of deep lots which invited rear buildings as land became more valuable. The lack of control which permitted industry, commerce and living quarters to mix indiscriminately in the same buildings and in the same blocks and neighborhoods added to the congestion. Until there is an intelligent replanning of the land and reasonable restrictions concerning the buildings and their use, uniformly good housing conditions cannot be expected.

The discovery of the iniquities of unrestricted tenement house occupation, the long fight to improve conditions by law and the present movement to control the use of land and buildings dictate the need for planning ahead. Housing evils show, as in a looking glass, the abuse which is stimulated by the possession of too much interior land in a block after intensified use has increased its market value. Commercial buildings share, in some degree, the disadvantages of blocks too large for the convenient arrangement of light rooms, but the complications run rather to street congestion. There is no use to which land may be put where the large block is more difficult to manage than in the areas devoted to tenement houses or small living apartments for low-paid wage earners.

The housing movement has thus shown the need for city planning. Its early laws have suggested some of the remedies. The need for good housing will bring into the city planning platform a solid plank which will lie firmly beside the architectural, the landscape and the engineering planks.

In I9Io the National Housing Association was organized, with Lawrence Veiller as secretary and director, for the purpose of improving housing conditions, both urban and suburban, in every practicable way. The Association states that "local associations or committees are organized, aid is given in campaigns of education, in drafting, enacting and enforcing legislation, in organizing improved housing companies, and in carrying on the continued work after good standards have been 
established." The National Housing Association issues a valuable quarterly called Housing Betterment and also publishes special bulletins. National housing conferences are arranged at intervals.

Organization of City Planners.-In 1909 the first City Planning Conference was held in Washington, D. C., the following year a conference was held in Rochester, and in I9I I Philadelphia was the scene of a most important conference and exhibition. Annually the conference now meets in some city which has interesting city planning achievements to show and which may be in a position to profit by the stimulation sure to follow a program devoted to city planning subjects. The membership is largely composed of architects, landscape architects, engineers, lawyers who have specialized in planning and zoning laws, and of commissioners of city planning who now hold office in the different cities and towns. The Conference has rendered a much-needed service to American cities and by inspiration and contact has undoubtedly improved the technique of the city planners. The principle of rotation in office is observed for elected officers, but Mr. Flavel Shurtleff has served continuously as Secretary of the Conference.

With the idea of creating a smaller body which could offer the opportunity to discuss professional and technical problems the City Planning Institute was formed in I917. The Conference published a quarterly called The City Plan, during the years I9I5-I6-I7 but was obliged to discontinue in I9I8 owing to the conditions brought about by the war. The first issue of a new City Planning Quarterly was published in January of 1925 .

One of the weaknesses of the city planning movement is exemplified in the membership of the City Planning Conference. Until recently there have been few members who were actually dealing in land. The contacts between the real estate dealers and the professional planners were few. It was an innovation when the United States Housing Corporation, during the war, added a real estate man to the architect, land- 
scape architect and engineer on the working committee for each project. Since in every community the real estate dealers exercise a potent influence on the development of the land the importance of establishing close working relations between them and the city planners cannot be overestimated.

Dealers in Real Estate.-When land was a drug on the market and every possible inducement was being held out to colonists by the English proprietors to persuade the early settlers to acquire land, there was usually an agent or representative of the proprietor but the tenant or purchaser ordinarily represented himself. As townsites were laid out the difficulty seemed to be to find purchasers who would build upon the lots.

Promoters of townsites and subdivisions for over a hundred years have struggled with the reluctance of investors to purchase land and build homes in new communities; but unless there are established industries or opportunities for trade which promise incomes to support those homes, the townsite is apt to remain a paper plan and the subdivision unoccupied except for the little white markers and the names of the proposed streets. There really is no shortage of space in this country in which to build homes. Even in the area of New York and its environs there is much open space which could be used for homes. It is not that there is too large a population in the area but that it is not distributed to the best advantage. Too many people seek to locate their places of business and their residences in "exclusive" or fashionable neighborhoods. "Keeping up with the Joneses" offers a perennial argument for crowding more people into areas that are already overcrowded. There is only one Fifth Avenue and Forty-second Street, only one Chestnut and Broad, only one Lexington and Charles, only one State and Randolph, only one Market and Powell in their respective cities to-day. The time may come when Fortysecond Street will suffer the same fate which Twenty-second Street suffered over a decade ago. The history of the rise and fall of fashionable residence neighborhoods in the cities of the 
United States would involve unending "human-interest stories" and produce fluctuating curves of physical appearance, human usefulness and market value.

The progressive subdividers of to-day recognize all of these elements and provide many residence neighborhoods to meet the requirements of the public. They have been slower to profit by the principles of city planning though there are notable exceptions. One of the reasons why subdividers have neglected modern planning is that people generally have proved rather undiscriminating in their choice of homes. Certainly there has been no wide-spread, irresistible demand for betterplanned subdivisions.

The men and women who deal in land have to do with the most fundamental element in the production of food, shelter, and clothing for the human race. In the buying and selling of land there was first the period of direct purchase and sale or trade; then the period of dealing through a third person, sometimes an attorney, later any business man who succeeded in "putting through the deal." It was natural, in the real estate business, as in many other commercial enterprises in the United States, that there should have been a period of rapid expansion without the adoption of uniformly high standards.

There is now on foot a most genuine movement to place the real estate business on a professional basis, to require an adequate training for those who practice the profession, and to set up standards, not only in regard to the buying and selling of land, but concerning its layout, management and use. There is no greater opportunity in the country to-day for a valuable contribution to the living conditions of the future than that which lies in the hands of the owners and dealers of land, both urban and rural. The scattered individual owners are not, and will seldom become, professional dealers in real estate, but the owners of land opened for subdivision and the dealers who buy and sell on commission, fall distinctly within the emerging professional field.

Already a few pioneers have indicated the vast possibilities 
in producing well-laid-out, well-managed residence communities, in which enjoyment of homes and maintenance of values are prime purposes. Dealers in land have already made contributions to the field of city planning and the real estate plank should be laid in the platform beside the other professional planks already mentioned.

Need for Trained Economists.-Both in the membership in the Conference on City Planning and in the actual application of the city plan there has been a disregard for the trained economist. City officials need more than pictures and plans. They need working drawings and schedules of cost. They need careful analyses of comparative costs. Sometimes the greatest economy involves the expenditure of money. Frequently the saving of money to-day means extravagant expenditures later. It is to be hoped that the groups of professional workers contributing to city planning will in the future include the trained economist.

\section{SUGGESTED READING}

Lewis Mumford, Sticks and Stones, I924.

Emma Richey and Evalina Kean, The New Orleans Book, New Orleans, I9I5.

Warren H. Manning, "The History of Village Improvement in the United States," in The Craftsman, February, I904. Reprinted.

Sarah Lewis Pattee, "The Early Garden Literature of America," in Landscape Architecture, April, I923, p. I79.

Downing's Landscape Gardening, revised by Frank A. Waugh, roth ed., John Wiley, I92I.

"Andrew Jackson Downing, Father of American Parks," in The Park International, July, rg20.

"The Improvement of the Park System of the District of Columbia," Senate Report No. I66 to the Fifty-seventh Congress, First Session. Government Printing Office, January 15, 1902.

City Planning Progress in the United States, compiled by The Committee on Town Planning of the American Institute of Architects, I9r7. American Institute of Architects, Report of Committee on Community Planning to the Fifty-seventh Annual Convention, April 3, 1924. 
American Institute of Architects, The Plan of the Federal City, 1924. Transactions of the American Society of Landscape Architects, 1909I92I, compiled and edited by Carl Rust Parker, Bremer W. Pond and Theodora Kimball.

Edith Elmer Wood, The Housing of the Unskilled Wage Earner, Macmillan, I9I9.

Lawrence Veiller, Housing Reform, Russell Sage Foundation, rgro.

\section{NOTES}

Page 47. Mr. Lewis Mumford in his book, Sticks and Stones, does not grant any virtue to the World's Fair. He objects to the "Imperial Façade" which he believes came into vogue as a direct result of the World's Fair. Says Mr. Mumford, "The evil of the World's Fair triumph was that it suggested to the civic enthusiast that every city might become fair; it introduced the notion of the City Beautiful as a sort of municipal cosmetic, and reduced the work of the architect to that of putting a pleasing front upon the scrappy building upon the monotonous streets and the mean houses, that characterized vast areas in the newer and larger cities." We think Mr. Mumford forgets that before the World's Fair architects in general had a pretty hard time to live and that architecture in the United States for the previous fifty or sixty years was such that the World's Fair could hardly have "reduced it." None of us approves of the false façade. Many of us disapprove of the block skyscraper, but it doesn't seem fair to blame them upon the World's Fair, which, taken in the long run, really started an upward trend which may yet culminate in something better than the middle nineteenth century ever produced. At any rate there are many signs to indicate that there may be better times ahead for architecture. We all hope so.

Page 53. The act provides for a Capital Park Commission to consist of the Chief of Engineers of the Army, the Engineer Commissioner of the District of Columbia, the Director of the National Park Service, the Chief of the Forest Service, the Officer in charge of Public Buildings and Grounds, the Chairman of the Senate Committee on the District of Columbia and the Chairman of the Committee on the District of Columbia of the House of Representatives. Under the provisions of the act appropriations not exceeding Ic for every inhabitant of the continental United States may be authorized by Congress. Under the 1920 census this would mean $\$ 1,050,000$ annually. Like all other appropriations, the amount must be recommended by the District Commissioners, approved by the Bureau of the Budget and duly appropriated by Congress, if it is to be made available. The Capital Park Commission in 
r 926 was merged with the Highway Commission to form the National Capital Park and Planning Commission.

Development of the City Planning Idea as Shown in Reports.-The history of City Planning in the United States began to take conscious shape in the late years of the rgth century and to flower into reports during the early years of the present century. The methods employed in gathering the basic data and the practices in forming conclusions vary greatly. A study of the reports during the early years discloses a rough outline of the dominating ideas.

The Report of the Senate Committee on "The Park System of the District of Columbia," written in I90I and presented to Congress early in 1902, covers rather more than its title would indicate though its authors made no claim that it included a comprehensive city plan. The report was based on careful studies of the trends of population and of the topography of the country. But the conceptions of the four eminent artists who collaborated in the making of the report bear the mark of genius.

In I 903 George Kessler, landscape architect, made a report for the Kingshighway Commission of Saint Louis which touched distinctly the larger planning field. In 1905 Messrs. Kelsey and Guild made a report to the Civic League of Columbia, South Carolina, which took the form of recommending many needed civic improvements. In this same year came the Buffalo report on the grouping of public buildings.

In I 906 Charles Mulford Robinson made his report on "Beautifying Honolulu," and this was followed by a long series of "Beautifyings"-the "Civic Improvement and Beautifying of Cedar Rapids," in 1908, the "Beautifying of San Jose," the "Civic Improvement and Beautifying of Santa Barbara," "Fayetteville's Opportunities," and suggestions to the Municipal Art Commission of Los Angeles in 1909; "The Wellbeing of Waterloo," and the "Improving of Fort Wayne" in rgro; "Better Binghampton" in I9II; "A General Plan for the Improvement of Colorado Springs," submitted to the Department of Public Works and Property in I 912 and "A City Plan for Raleigh" in I9r3. These reports contained many sane suggestions for civic improvement. The reports were in line with the dominant thought of those years. They recommended removal of overhead wires, the planting of trees and gardens, the orderly arrangement of sidewalks, curbs and paved roadbeds, the abolishing of unsightly signs, the improvement of rail and water entrances, the extension and improvement of parks, the development of ornamental open spaces, the establishment of play grounds, the transformation of roadways into boulevards and pleasure drives, with occasional readjustment of street plan to avoid awkward angles and unnecessary traffic congestion. The outward and visible features of the 
city received the first consideration. It was not until the second decade of the century that the apostles of the beautiful made close connection with the engineers of the unseen and underground utilities to form a more complete plan. In this third decade we are only coming to see the close working co-ordination which must include all social and economic groups if the city plan is to be comprehensive in scope as well as in territory.

The year 1907 saw a sheaf of city planning reports. In that year John Nolen put out his report on "Remodeling Roanoke," and Emerson and Whitman, Engineers, a companion volume called "Sanitary Roanoke." A "Plan of Elgin" prepared by E. H. Bennett, Consulting Architect, was published by the Elgin Commercial Club. The Civic Committees of the Civic League published "A Plan for Saint Louis" in a volume running over roo pages. A Report of the New York City Improvement Commission to the Mayor, made in 1907, grew out of the realization of the problems created by the congestion of the population and resultant traffic difficulties and paved the way for the reports of the Heights of Buildings Commission issued in 1913 which were followed by the final report in I9I6 of the Commission on Building Districts and the Building Zone Resolution restricting the height and use of buildings and prescribing the minimum sizes of their yards and courts. The report of 1907 may be said to have led directly through consecutive steps to the zoning regulations now in force.

The year 1908, besides the Robinson Reports, saw the Report of the Commission on the Improvement and Beautification of Utica by Frederick Law Olmsted and the Report of the Plan Commission made to the Mayor and the Board of Public Service on the "Plan for the City of Columbus."

But judged by its character, scope and application by far the most important report issued in 1908 was that on The Chicago Plan which appeared in a handsome volume containing 164 pages and 134 drawings, charts, and pictures, including fifteen full-page, six-color reproductions from paintings of the famous artist, Jules Guérin. The Chicago Plan Commission was created in 1909 as a result of the report and there followed a long succession of pamphlets and communications to the public, including "Wacker's Manual of the Plan of Chicago" which is now in its third edition. In I9I9 more than 50,000 copies had been distributed in the schools of Chicago where it is a part of the regular course of study.

The Chicago Plan was prepared by Daniel H. Burnham, assisted by Edwin H. Bennett under the auspices of The Commercial Club which in 1907 merged with The Merchants' Club under the name of the older organization-The Commercial Club. Franklin MacVeagh, 
Charles D. Norton, Frederic A. Delano, Walter H. Wilson, Edward B. Butler and Charles $\mathrm{H}$. Wacker were all associated with the promotion of the plan in its early stages. Mr. Wacker as Chairman of the Chicago Plan Commission since its creation in 1909 has proved indefatigable in putting into effect one after another of the recommendations of the report of 1908. The report was noteworthy but the method of educating the citizens of Chicago was even more record-breaking. Through "Wacker's Manual," through a long succession of lantern-slide talks, lectures and trips, every school boy and girl as well as every man and woman in Chicago must have heard of the Chicago Plan and caught some little flicker of the spark of enthusiasm in the enterprise of making Chicago the most beautiful and convenient city in the world. And it is this education which counts when the voters are called upon to authorize huge bond issues to put the Plan into effect.

In 1909 came the Preliminary Report to the Mayor and Common Council for a "City Plan for Grand Rapids" by Arnold Brunner and John M. Carrere, the Report of the Pittsburgh Civic Commission, the first of a series of reports which led to the creation of the Pittsburgh City Plan Commission in I9II and a recent series of technical studies extending over a number of years. It was in this year that the first National City Planning Conference was held in Washington. The subject of City Planning was coming to be recognized.

In I9ro there appeared the report of the Park Board on "A City Plan for Dallas," made by George E. Kessler, the Report of the Minneapolis Civic and Commerce Association on the "Limitation of Heights of Buildings," the Report to the New Haven Civic Improvement Commission by Cass Gilbert, architect, and Frederick Law Olmsted, landscape architect, the Report on the Oklahoma City Plan for an Outer Parkway and a Plan for an Interior System of Parks and Boulevards by W. H. Dunn of Kansas City, and John Nolen's Report on "Replanning Reading, an industrial city of 100,000."

In IgII there appeared the reports on two Wisconsin cities, "The Making of a Park System in La Crosse," by John Nolen and "Madison a Model City," by the same author; the "City Plan for Rochester," prepared by Arnold W. Brunner, architect, Frederick Law Olmsted, landscape architect, and Bion J. Arnold, engineer; the "Plan of Seattle," a report of the Municipal Plans Commissions prepared by Virgil C. Bogue, engineer, and the inclusion of a section on city planning in the report of the Bureau of Surveys of Philadelphia, following the exhibition and National Conference on City Planning held in that city during the year.

Every year since has seen new reports, mounting in number and in magnitude of scope and detail of basic data. These early reports are 


\section{SHORT HISTORY OF CITY PLANNING IN THE U. S. 73}

thus carefully enumerated as they show so clearly how the professional surveys and recommendations followed the trend of thought. The ideas which made possible the organization of the American Civic Association in I904 made possible the preparation of these reports generally at the instance of local civic organizations. As progress was achieved and planning commissions formed the reports came to be directed to municipal officials and legislative bodies. 


\section{CIVIC IMPROVEMENT AND CITY PLANNING}

Toward the end of the nineteenth century the general public began to manifest an interest in parks, outdoor art, conservation of natural resources, preservation of great natural scenic wonders. The general public, too, began to indulge in golf. Tennis became a game accepted by the country. The development of public parks was constantly broadening the opportunity of the people for some sort of outdoor recreation.

At a meeting of the Park Commissioners at Louisville, Kentucky, there was organized in 1897 The Park and Outdoor Art Association which next year changed its name to the American Park and Outdoor Art Association. In the meantime at Springfield, Ohio, there was launched in 1900 the National League for Civic Improvement Associations which changed its name to the American League for Civic Improvement.

These two organizations were united in 1904 into the American Civic Association at a conference held on the Saint Louis Louisiana Purchase Exposition Grounds. The American Park and Outdoor Art Association sought to promote the advancement of landscape art, the extension of public parks, and the conservation of natural scenery. The American League for Civic Improvement sought "to bring into mutual helpful relations the great national movement of the individual worker, the publisher and the manufacturer, thus inspiring practical co-operation between all the factors in making 'America the most beautiful country in the world,' with its citizens the best educated and the best governed."

The American Civic Association in its constitution set forth 
its purpose as "the cultivation of higher ideals of civic life and beauty in America, the promotion of city, town and neighborhood improvement, the preservation and development of landscape, and the advancement of outdoor art." Dr. J. Horace McFarland became its first president and for twenty years led the "crusade for civic improvement." Personally Dr. McFarland visited more than five hundred towns and cities to stimulate and guide local action for improvement.

Let us picture the typical American town which Dr. McFarland found on his travels. Who does not recall that broad expanse of Main Street, with its unnecessary width of pavement, with its great "white way" of brilliant globules of light throwing into sharp relief the bare, stark structures in which the town conducted its business-the corner drug store, the meat market, the grocery store, the harness shop, the dry goods emporium, the hardware and implement mart, the commercial hotel, the town dance hall and lecture room, the new six-story office building with an elevator, and, more recently, the moving picture palace? These buildings usually stood at different distances from the street and faced on sidewalks of all widths and materials, with not a spear of grass or a tree in sight between the gloomy railway station at the foot of the street and the residences on upper Main Street. There was found a motley array of houses which might serve as a history of the various sorts of architectural monstrosities which have been perpetrated in the late nineteenth century.

But the outward appearance of the commercial buildings and homes was not the only offense of the town. There were the struggling street trees of silver maple, box elder and even some better varieties, planted by owners of the lots when and where they pleased without regard to their neighbors; there was the ragged, neglected space between the sidewalk and the roadway; there were the telegraph and telephone poles and wires for which the tops of the trees had been sacrificed and there was, if the town was very progressive, a public square with its formal beds of mixed colors and the name of the town done 
in shells and live-forever plants. Even the new subdivision which had superseded in fashion the old addition, with its rather bare stretches of lawn, devoid of fences or hedges and the formal grouping of vari-colored evergreens dotted with blue spruce, its new stucco houses and its great expanses of cement, presented little to warm the heart or comfort the body under the broad glare of the sun.

But in one town after another little groups of public-spirited citizens sought to "improve" the place. They turned to the new national civic association to guide them. During the years there were various first steps. Sometimes the women's clubs (for the women's clubs woke up first) inaugurated "Clean Up" Campaigns. They persuaded the citizens to clean up their own premises; they persuaded the business men to clean up their places of business; they persuaded the city fathers (there were no city mothers in those days) to provide for a system of collection and disposal of garbage, rubbish and possibly ashes. In other towns the first move toward civic improvement came through gardens-flower gardens and vegetable gardens in back yards and vacant lots. Garden contests have been found conducive to amicable co-operation and add to the appearance of the town.

In I913 the American Civic Association issued a pamphlet on "Civic Improvement in the Little Towns" by Miss Zona Gale which was particularly addressed to the women's clubs as "one of the surest means at hand for rousing civic consciousness," as "this phase of the new desire of women for expression is peculiarly fitted to develop from the previous training of women." Miss Gale set forth the problem of the small town thus:

"I. To get into the current of the new understanding that the conservation of physical and moral life is largely economic, and that its enemy is not so much individual human weakness as bad economic and social and other physical conditions.

"II. To find practical ways of applying this understanding to the present and future of the town, and so of the democracy. 
"III. To do both with exceedingly little money.

"The first need is not to change town conditions. The first thing is to create the desire to change town conditions. That is, the first step is, as usual, educational. People must begin to think about civic work before they will begin to $d o$ civic work."

Miss Gale suggested committees on education, outdoor art, children's auxiliary, streets and alleys, rest-room, charity coordination, public buildings and recreations, sanitation, medical and dental inspection, garbage collection. As one of the means of support she suggested a flower show. A few of these subjects would to-day fall within the distinctly social or educational fields, but most of them are related to the physical arrangements of the town.

But whether the visit of Dr. McFarland was to the little town or the growing city, and whatever the project first undertaken, like the young lady's red bonnet which induced a complete revolution of costume, the civic endeavor led inevitably to more complicated and fundamental needs. It was discovered that it was not only the lack of architecture and the absence of parks from which the towns suffered. The streets were laid out improperly; the lot sizes were too deep for their uses, hence the occupation of back yards for repair shops and even for habitation. - It was discovered that the discarded mansions of earlier days were being turned into tenements without even the comforts and privacy afforded by the iniquitous cold-water walk-ups of New York. It was discovered that for all the vacant land there were no playgrounds with equipment and no supervised play. The children were running wild and learning much that would handicap them in later life. It was discovered that even the school depended upon a vacant block near by for play space and sooner or later, it was realized, this ground would be used for building purposes.

It was more than probable that the water supply was proving inadequate and not entirely safe; a sewerage system was needed; there was a demand for extended paving, particularly in those early years when everybody who could afford it, and 
some who could not, had purchased automobiles. Accidents at the sharp jog at the end of Main Street where it joined the country road were becoming far too numerous. Several citizens who dodged under the gates swung down by the gateman at the main railway crossing had been killed, and each year there were catastrophes at the unguarded grade crossings of the railway and streets.

As these larger projects intruded themselves upon the consciousness of the citizens, it happened not infrequently that the chamber of commerce or trade organization began to see that it was only by providing well laid-out streets, good schools, good libraries, pure water supply, adequate sewage system, regular collection of garbage, convenient homes with modern plumbing, proper fire protection, well-planned parks and playgrounds, safety from dangerous railway crossings and all those things which go to make a good town, that they could hope to attract new industries and new business.

For American citizens were becoming sophisticated. They were traveling around on trains and in automobiles. They saw good towns. They saw good homes, good parks, good playgrounds, pleasant tree-shaded avenues, and they began to discriminate between the good and the bad. Therefore the owners of factories desired to locate in towns where they could offer good living conditions in order to compete with other employers of labor. Dealers in drugs, dry goods, boots and shoes, or whatnot, in seeking new locations, reasoned that towns which provided facilities that Americans were coming to demand, were much more likely to grow and provide a profitable custom for them. Professional men and women were particularly discriminating. Good teachers did not need to go to towns where the living conditions were poor. Good professional men in any field-doctors, lawyers, ministers-preferred to live in towns which oifered conveniences and comforts.

And so it happened that the good towns grew progressively better and the poor towns progressively poorer because of the kind of citizens they attracted. But during the past twenty 
years the American Civic Association, through personal contact of its president and leaders, through correspondence, through public conferences, through publications and in many other ways, has given advice to American communities in order to start them in the right direction and guide their efforts until they came to the place where they realized that they needed technical assistance in the way of a City Planning Survey which would provide them with a program for the future. After the survey has been made and the program adopted, the Association offers to public officials such as Plan Commissioners or others an information service concerning the experience and practices of other cities in all the many phases of application which are involved in realizing any city plan.

It was only natural, therefore, that an association which had for so many years rendered first-aid to American towns and cities, should turn its attention to the needs of the Capital of the Nation. In the spring of 1923 the association organized in Washington a Committee of 100 on the Federal City under the chairmanship of Mr. Frederic A. Delano. This committee succeeded to the name and the good will of a former committee which had disbanded in 1917. Throughout the country field committees on the Federal City were organized to co-operate with the Washington committee to protect the development of Washington as a capital city of world-wide importance.

During the twenty years of its existence the American Civic Association has taken an active part in the education of the public to the value of national parks and led in the fight to create a National Park Service. Since I9I 6 when this bureau was set up in the department of the Interior, the Association has co-operated with the National Park Service and has appeared before committees of Congress to advocate bills thought to be of benefit to the people and to oppose bills which seemed to be to the advantage of special interests rather than the public.

The Association long advocated the establishment of a housing and planning bureau and has co-operated with the Division 
of Building and Housing which was set up in $192 \mathrm{I}$ under the Bureau of Standards in the Department of Commerce.

It was not surprising that in the early years which followed the revival of architectural standards and the development of the profession of landscape architecture the emphasis in civic development should have been placed on what was then called "The City Beautiful." To-day we are not ashamed of the City Beautiful, but we know that beauty is not a false front to be slipped over the framework of a city to improve its appearance. We realize that under the ground, within the factories, the office buildings, the stores, the markets, the apartment houses, the homes, the unseen must be planned and built just as carefully as the seen. We have come to appreciate that the planning of a city is a vast undertaking which must enlist the services of architect, landscape architect, engineer, dealer in land, housing expert, economist, social worker and civic leader, not necessarily in each specific instance by the collaboration of so many separate individuals but emphatically by so many points of view and by so much technical knowledge and experience.

And because planning and park development are all part of civic improvement, through the good auspices of the President's National Conference on Outdoor Recreation, the American Civic Association joined with the National Conference on City Planning, the American Institute of Park Executives, the American Park Society, and the National Conference on State Parks to form the Federated Societies on Planning and Parks. This new Federation, organized in 1925 , promises effective cooperation in the field of physical environment of the American people. It is proposed to collect all printed and map material available, together with graphs, photographs and slides, with the idea of forming a "dynamic library," that is, a library of current information which, through the aid of specialists, can be interpreted and made available to civic leaders and interested citizens in all parts of the United States. A central clearing house of information should eliminate much waste 
effort, should dispense reliable information, and should establish a leadership through publication of the latest thought and experience in the civic planning field.

\section{SUGGESTED READING}

Bulletins issued by the American Civic Association:

Frederick Law Olmsted, City Planning, out of print.

Zona Gale, Civic Improvement in Little Tozens, out of print.

Dick J. Crosby, Children's Gardens.

J. Horace McFarland, The Awakening of Harrisburg.

Frank A. Waugh, Country Planning.

George B. Dealey, Getting into Action for a City Plan.

JoHn Nolen, A Good Home for Every Wage Earner.

J. Horace McFarland, Illegal Signs in Pennsylvania.

Hon. Willitam H. Taft, Viscount James Bryce, Hon. Walter L.

Fisher and J. Horace McFarland, National Parks.

Frederick L. Ford, Public Comfort Stations.

J. C. Nichols, Real Estate Subdivisions.

MARGaret Woodrow Wrison, The School House as a Community Center.

Harlan P. Kelsey and Frederick Law Olmsted, The Smoke Nuisance.

ANDREW WrIGHT CRAWFORd, Important Advances in Eradicating the Billboard Nuisance.

Andrew Wright Crawford, Good Sense and Good Taste in War Memorials.

Lawson Purdy, Harland Bartholomew, Edward M. Bassett, Andrew

Wright Crawford and Herbert S. Swan, Zoning as an Element in City Planning, and for Protection of Property Values, Public Safety and Public Health.

Municipal Planning, Park and Art Administration in American Cities. Collated from replies to Questionnaire sent out by the American Civic Association.

Frederic A. Delano, Harland Bartholomew, George B. Ford, Lawson Purdy, Harlean James, City Planning Procedure.

Publications of the Department of Commerce, Washington, D. C.:

A Zoning Primer.

By the Advisory Committee on Zoning: Edward M. Bassetr, Irving B. Hiett, John Ihlder, Morris Knowles, Nelson P. Lewis, J. Horace McFarland, Frederick Law Olmsted, and Lawrence VEILLER. 


\section{LAND PLANNING IN THE UNITED STATES}

How to Own Your Home.

By John M. Gries and James S. Taylor, with a foreword by Herbert Hoover.

Recommended Minimum Requirements for Small Dwelling Construction. By the Building Code Committee: IrA H. Woolson, chairman; Edwin H. Brown, William K. Hatt, Rudolph P. Miller, J. A. Newlin, ERNest J. Russell, and Joseph R. Worcester.

Recommending Minimum Requirements for Plumbing in Dwelling and Similar Buildings.

By the Subcommittee on Plumbing: George C. Whipple, chairman; Harry Y. Carson, William C. Groeniger, Thomas F. Hanley, and A. E. HANSEN.

Materials for the.Household.

Government Printing Office, Washington, D. C.

"Recommended Minimum Requirements for Masonry Wall Construction." A Bulletin issued by the Division of Building and Housing of the Department of Commerce.

"Minimum Live Loads Allowable for Use in Design of Buildings." A Bulletin issued by the Division of Building and Housing of the Department of Commerce.

A Standard State Zoning Enabling Act. A Bulletin issued by the Division of Building and Housing of the Department of Commerce.

Dwellings and Families by States and Large Cities (Census). A Bulletin issued by the Division of Buildings and Housing of the Department of Commerce. 


\section{PRINCIPLES OF CITY PLANNING}

We have proceeded thus far without any attempt to give a formal definition of City Planning, but we shall have failed of our purpose if the reader has not formed some picture of the planning and replanning of cities and some idea of the complicated problems involved in the application of the principles of City Planning. No definition could apply accurately to all periods of history and at the same time supply sufficient detail to make a working program for any one period. On the other hand, no contemporary definition can carry that richness of understanding and that broadness of vision which a knowledge of the achievements of the past can give to any program for the future.

City Planning May Be Said to Be the Public Control, Through Planning in Advance, of the Physical Treatment of Public and Private Land and Its Appurtenances in the Interests of the Community as a Whole 2 -During the first century of our Republic the control of publicly-owned land, such as streets, with their utilities, developed from a time when little responsibility was assumed by the city or town government to the present day when a large proportion of taxes goes to the maintenance of streets. During the second century we have begun to extend public control over privately owned land when it could be clearly shown to the courts that such control was in the interests of the health, safety, morals or general welfare of the community as a whole.

The cardinal conception of modern City Planning is that all of its parts, such as streets, transportation, utilities, buildings and open spaces, be designed for an entire community and not 
block by block or lot by lot. Some of the most dismal failures in the building of cities may be traced to piece-meal planning, sometimes designed by well-meaning planners, often left to chance. The hit-or-miss mosaic which is the result of mapping the detail first and trying then to fit it into a picture puzzle cannot be dignified by the name of planning.

All City and Town Planning Should Include a LongRange and a Short-Range Program.-Both should be subject to periodic overhauling to meet changing conditions and to modifications and adjustments to keep the land in the best possible use which the growth of the population will permit. In Detroit the long-range plan is called the "master plan," an excellent designation.

But the Long-Range Plan Should Be Determined First and the Short-Range or Intensive Projects Designed to Fit into It.-Only thus can organic unity be secured. There are many modifications which need to be made as population trends produce changing conditions. The longrange plan, if it is truly useful, should be projected by city planners of vision who know how to penetrate the future. The difference between George Washington, Thomas Jefferson and Alexander Hamilton and the small forgotten contemporaries who criticized them bitterly when they lived is just this difference in the vision for the future. All of these men made minor predictions which have never come true. But they were able to visualize the main essentials of the future Republic. They made no little plans.

To-day any good landscape architect can lay out a charming park; but the comprehensive planning of great cities should be placed in the hands of the few planners who have demonstrated that they "have the magic to stir men's blood." The specific projects may frequently be planned and carried out by lesser men.

City Planning concerns itself, first, with the location of means of circulation, including streets, rail and water transportation, transit, traffic, utilities and spaces needed for load- 
ing and unloading or transferring passengers and freight. The principle of public control of means of circulation made rapid advances during the nineteenth century. The principle is now quite thoroughly established. The physical difficulties are the ones which trouble us, and these difficulties can be solved only by planning ahead for long periods with the advice and counsel of technical engineers of a high order.

City Planning concerns itself, next, with parks and open spaces. The principle of public control and administration of parks is well understood and generally accepted by this generation. But the variety and character of the services rendered to the people by the cities of the United States has grown rapidly in the last quarter of a century. The types of city parks have also increased in number and the conception of metropolitan park systems has become more and more important in the city plan.

City Planning has from the beginning in this country concerned itself with public buildings and grounds. Not only have Civic Centers become popular, but citizens are beginning to see the advantages of careful distribution of public schools, branch libraries, fire and police stations. Public control of public buildings is undisputed and in recent years has been rather more intelligent than that exercised during the last half of the nineteenth century.

But probably the most important advance of City Planning in the last twenty-five years was made when it began to concern itself with zoning. By means of zoning city governments may district the city into sections which may be regulated as to use, height of buildings, and area covered by buildings. Thus the right of land owners to put their property to uses which destroy their neighbor's enjoyment in their property and rob the property of part of its value is definitely curtailed. The community as a whole is by this means setting up safeguards against the depredations of individual owners.

But the zoning of an existing city is confined in general to protecting districts already established, at least in so far as the 
built-up sections are concerned. An area may be zoned to reflect its predominating features, but with the lack of retroactive zoning laws, it may be years, even generations, before certain non-conforming uses can be eliminated. The occupied areas of most cities, therefore, act as a rigid cast to control the future. Zoning frequently projects the errors of the past into the future. Zoning unaccompanied by comprehensive planning is at best most inadequate and at worst a positive menace to the future unity of the city.

Under the uncontrolled growth of cities the tendency has been to develop a rectangular down-town section completely surrounded by industrial, residential and mixed districts in more or less solid blocks of considerable size. The commercial areas cannot ordinarily expand by pushing industry aside. They are often hemmed in by obstacles such as parks, cemeteries, established residence neighborhoods. An unhealthy intensive use of land is apt to result. Small shops may push their way out in one or more long arms towards the suburbs, generally following the street car routes. Under such conditions the complete transformation of many city blocks must be effected in each generation to permit business to extend its space.

Under the modern theory of city planning the city, instead of building up in rectangular areas, will develop around a down-town district an arterial street system which will divide the city into more or less irregular sectors, narrow near the center but ever widening as they stretch out into the country. Thus industry may be provided with a contiguous outlet. Business may push its long arms out into the surrounding regions and may even take over the residential sections which are ready for re-development. But the residential sections lying between the arterial highways, especially when they follow the winding course of a wooded stream or the pleasant green of an artificial parkway, may be protected. The increasing values of land near the business center may force a more intensive use of some residential areas by stimulating apart- 
ment buildings to take the place of single-family dwellings; but even this encroachment upon a section which the topography clearly indicates is particularly well fitted to residences surrounded by yards, may be delayed or avoided altogether by proper protective features which will not stultify business but permit it to grow in other directions.

Residences near the down-town districts are abandoned for building sites further from the business center mainly because of two reasons, one, because of increasing taxes and possible selling prices and, two, because the country features are destroyed by the outward push of business. If the country features were preserved one of the reasons would be eliminated. If business were provided definitely with adequate and controlled paths of expansion and taxes adjusted to reflect the difference between business and residence values of the various grades the other reason would be modified and possibly removed.

At any rate a city planned in sectors, adapted to the natural topography would face far fewer changes in zoning districts than one in which it is necessary to transform the character of large and pleasant residential areas in order to provide a space for growing business.

But whether a city is planned in sectors or not, there is need for the careful classification of the different districts. In all attempts to classify land, there are areas which readily fall into one classification or another and there are other spaces which are difficult to classify. From decade to decade and from one generation to another, the outward push of the city forces changes in classification of specific areas. For this reason the long range elements may be blocked out for thirty, forty, even a hundred years in advance; but the detailed planning for areas not to be occupied for half a century is apt to miss the mark and so prove a waste of time and money.

It will be seen clearly that all the physical features of the city must be considered as inter-related. Water and sewer levels dictate the layout of building lots for homes. Many a 
subdivision which might offer charming wooded building sites is utterly ruined by the established city grades of streets and their utilities. It is usually possible to use a sloping wooded area to excellent advantage for the building of homes if the streets can be arranged to make the property available with iittle cut and fill. The problem of providing building lots of uneven elevation with water at proper pressure and sewers with sufficient gravity flow can usually be met if the project is studied with competent engineers.

In practice, however, beautiful wooded slopes too frequently are denuded of their trees, stripped of their top soil and terraced into clay strips, a practice which brings many of the lots on the lower side of streets so far below grade that they, too, must be filled at great expense, and the whole area developed into an ugly, bare expanse divided into long narrow lots ill adapted for homes and yards.

But all the safeguards of intelligent planning do not operate in the interests of the home neighborhoods. Industry, too, should be safeguarded and provided with proper facilities. Careful study of the rail and water transportation facilities will develop areas where industry may be supplied with adequate sites supplied with neccessary conveniences. It is not to the best interests of industry that routes of traffic needed by industry itself should be blocked by through traffic which has no relation to the industry.

No city can hope to achieve a unified plan unless there is a central clearing house for all the elements of the city plan. Parks and parkways, school sites and playgrounds, main highways and lesser streets, transportation and transit systems, public utility plants and distribution systems, areas assigned for industrial, commercial and residential purposes; all these plans must be co-ordinated if they are to supplement each other and join into a convenient, harmonious whole. However carefully and scientifically these different elements may be planned, they must all be placed on the same map; they must all be correlated within a given area of the earth's surface. 
Many surprising discrepancies are discovered when existing conditions and broad general plans are placed on the same map.

The city which does not bring its various elements of planning into harmony is like the human body with the circulatory system entirely unrelated to its alimentary system or like an automobile engine in which the gasoline supply never connects with the ignition.

\section{SUGGESTED READING}

Nelson P. Lewis, The Planning of the Modern City. John Wiley \& Sons. Second edition, 1922 .

Theodora Kimball, Manual of Information on City Planning and Zoning. Howard University Press, 1923.

Frank B. Williams, The Law of City Planning and Zoning. Macmillan, 1922.

Charles Mulford Robinson, City Planning-with Special Reference to the Planning of Streets and Lots. Putnam, I916.

John Nolen, in the Introduction to City Planning, a series of papers presenting the essential elements of a city plan. National Municipal League Series, I916.

Hardand Bartholomew, A Comprehensive City Plan, Memphis, Tenn., 1924.

JoHN Nolen, "Planning Projects for Elkhart, Indiana." Paper read at 24th annual convention of the National Association of Real Estate Boards, I922.

George H. Herrold, "A Monograph on City or Village Planning and Zoning." A Bulletin issued by The League of Minnesota Municipalities from the Executive Offices of the University of Minnesota Library. January, 1925.

Arthur C. Comey, Regional Planning Theory, A Reply to the British Challenge. 1923. Published by the author.

"Zoning." A Bulletin issued by The League of Minnesota Municipalities from the Executive Offices of the University of Minnesota Library. January, 1925 .

Frederick Law Olmsted, in Proceedings of the Second National Conference on City Planning, Rochester, May, I9ro. Also published in the Introduction to City Planning, John Nolen, I916.

Advisory Commitree to the Common Council, Detroit, Carrying Out the Master Plan. October 2, I925. Second edition, December 26, I 925 . 


\section{NOTES}

Frederick Law Olmsted, in the Introduction to City Planning, Igr6, said:

"City planning is the attempt to exert a well-considered control on behalf of the people of a city over the development of their physical environment as a whole. Although most of the elements of the subject have been long under discussion and have accumulated an extensive literature, books purporting to treat of city planning are few in number and all of recent date. Indeed the term itself, and its equivalent, 'town planning,' have come into use only within a few years.

"The new and significant fact for which this new term, 'city planning,' stands is a growing appreciation of a city's organic unity, of the interdependence of its diverse elements, and of the profound and inexorable manner in which the future of this great organic unit is controlled by the actions and omissions of today. . . .

"City planning stands not only for a longer look ahead in planning municipal improvements than has been custnmary in the past, but especially for a broader and more penetrating vision of the interrelations between apparently distinct lines of planning in cities, and of the profound influence which activities carried on in one part of the fieid, and with a view to one set of purposes, may have on conditions on another part of the field. It takes account of the influence of street plans and depths of blocks upon the prevailing type of building and thus upon the amount of light and air and privacy in the people's dwellings; of the effect of railroad locations on the distribution of factories and on the congestion of population and character of housing; of the economic interrelation between water-supply lands and park lands; of the social and economic values to be secured by grouping numerous educational and recreational functions which have ordinarily been separated; and of other combinations innumerable. . . .

"The common sense application of the city planning ideal may be phrased thus: Whether they like it or not, whether they know it or not, a collective responsibility rests upon citizens of the present generation for making or marring their city's future in countless ways. It is utterly beyond their power, or that of their agents, to discharge that responsibility with complete knowledge or infallible wisdom; but it is reasonable that they should use a moderate amount of their collective energy and wealth in a deliberate and conscientious effort to meet the responsibility as well as the available means permit."

Mr. Frank B. Williams defines city or town planning as "the guidance of the physical development of communities in the attainment of unity in their construction. Wherever in any locality a sufficient concentration of population has occurred to create complexity, here will be found a network of interests, each seeking its expression in the physical life of that locality; and it is the task of city planning, either by prevention or by cure, to bring these interests into harmony, in the unity of that locality. 
The "Manual of Information on City Planning," by Theodora Kimball, declares simply that "city planning is the control and guidance of the physical development of cities and towns." She quotes Mr. Bassett's well-known definition that city planning "deals actually with those elements of city life which can be expressed on maps-with streets and buildings and parks, with railroads and docks." But in the application of city planning Miss Kimball explains that "this 'dynamic' plan or map is not fixed once for all and incapable of change; its main outlines being fixed, its detail is constantly developing as the city grows and changes."

Writing in 1916 Charles Mulford Robinson in his book on "City Planning" analyzes the term thus:

"Town planning includes three operations. The term is applied to the replanning of existing cities and towns, to the planning of new towns, and to a scientific platting of new sections of existing towns. The benefits that are sought by it are, in their turn, speaking broadly, three in number. They are an improvement in those circulatory conditions created by indirect streets and congested traffic, the betterment of social conditions in many directions-notably in that of housing; and an increase in the visible beauty and splendor of cities. Under these headings, gains are anticipated in economy, efficiency, health, comfort and looks."

He quotes on the title page from a leaflet issued by the Minneapolis Civic and Commerce Association a very apt definition:

"Town planning is the art of laying out cities to serve the business requirements, convenience, health and comfort of the public. It is guiding the growth of a village or city in conformity with a scientific design. It is adapting the physical form of the city to the peculiar needs of its parts."

Mr. Nelson P. Lewis, in his book on "The Planning of the Modern City," presents a brief definition.

"City planning is simply the exercise of such foresight as will promote the orderly and sightly development of a city and its environs along rational lines with due regard for health, amenity and convenience and for its commercial and industrial advancement."

Mr. Lewis quotes Mr. Arnold Brunner's statement that "the basic principle of city planning is to increase the working efficiency of the city," and that of Mr. George B. Ford that "City planning is the name given to the science and art of providing for the most practical and agreeable development of a city or town."

Mr. Harland Bartholomew has given a very practical definition of city planning:

"City planning is that phase of municipal activity which analyzes the character and probable extent of the city's growth, suggests 
certain physical readjustments and provides for the coordination of all future improvements. Under proper and sympathetic administrative agencies it would make possible the gradual and economical development of an orderly, well-arranged city which would provide good living conditions for all its citizens, be everywhere wholesome and attractive in appearance and free from those physical defects that hamper commercial and industrial activity. . . . City planning is essentially concerned with the physical development of cities. It has nothing to do with political interests or factional differences. The city plan is a beneficial instrument affecting the lives of all city dwellers so long as the city endures. It should transcend all other considerations."

Mr. J. C. Nichols has very definitely corrected a popular misconception:

"There has been a wrong impression that city planning is nothing more or less than the embellishment and beautification of the city, whereas, as a matter of fact, it is the lopping off of the unnecessary things; it is the cutting down to the practical things that makes your city efficient, that makes it responsive to every call that is put upon it; and out of that order, out of that very rhythm of movement, out of the ability to do the things placed upon it, will come the 'City Beautiful.'"

But no one has given voice to a better description of city planning than Dr. Charles W. Eliot, President Emeritus of Harvard University:

"Good planning for cities and closely-built towns and villages is not primarily a matter of æsthetics, but of economics. The main object is to prevent or remedy the physical and moral evils and losses which accompany congestion of population.

"The laying out of most American cities has been casual, and thoughtless of future needs. The common rectangular layout without any well-considered diagonals, causes a great daily waste of human and animal labor and of fuel, while high buildings, narrow streets, and lack of open spaces make it impossible to keep the cities well aired and sunned. To improve or reform the layout of most American cities is therefore a great public need, not only for beauty's sake but for the sake of the health, efficiency, and happiness of their people."

"City planning may be conveniently considered under three main divisions," according to Mr. Olmsted. "The first concerns the means of circulation-the distribution and treatment of the spaces devoted to streets, railways and waterways, and all means of transportation and communication. The second concerns the distribution and treatment of the spaces devoted to all other public purposes. The third concerns the remaining or private lands and the character of developments thereon, in so far as it is practicable for the community to control or influence such developments.

"Facility of communication is the very basis for the existence of cities; improved methods of general transportation are at the root 
of the modern phenomenon of rapid city growth; and the success of a city is more dependent upon good means of circulation than upon any other physical factor under its control.

"Moreover, the area devoted to streets in most cities (excluding those regions that are still undeveloped) amounts to between 25 and 40 per cent of the whole, and the improvement and the use of all the remainder of the city area, both in public and private hands, are so largely controlled by the network of subdividing and communicating streets that the street plan has always been regarded as the foundation of all city planning. But even as to streets, plans drawn primarily in the interest of easy communication, with a view to the common welfare of all the citizens, and by agents responsible to them, have been unusual.

".. . Nearly all new city and town sites that have been deliberately planned, whether well or ill, have been planned by or for the proprietors of the site, largely with a view to successful immediate sales. Moreover, the methods, traditions, and habits created in this school have inevitably dominated in large measure those official street planning agencies which the people of some cities have subsequently established with the purpose of exercising a control in the interest of the whole community over the street layouts of individual proprietors."

In the chapter on the "Elements of a City Plan," Mr. Lewis analyzes the subject thus:

"Without regard ... to the various municipal activities and administrative details, the convenience and attractiveness of a city will depend chiefly upon four features of its plan:

"I. The transportation system or the means provided for getting in and out of the city, and for the quick movement of passengers and freight from one part of the town to another. It is obvious that transit needs cannot be accurately foreseen; but provision should be made for improving and extending them when needed. A large part of the transportation will always be in the streets themselves, and its adequacy and efficiency will be largely determined by the location and dimensions of the streets in which the intra-urban transit lines are located.

"2. The street system in and through which the daily business is done and by which the people gain access to their homes and pass from these homes to their work, recreation and amusement. A street system once adopted and developed must remain indefinitely.

"3. The park and recreation facilities upon which the comfort and health of the community are to a large degree dependent. It is true that a lack of proper parks may be supplied at any time, even when the space to be devoted to that purpose shall have been built upon and when the cost of their acquisition will be greatly enhanced, but a park system can be most economically and satisfactorily established in advance of other improvements and facility of access to them and proper connections between the different park units will depend upon the street system, so that it is desirable that the park plan be worked out in connection with the street plan. 


\section{LAND PLANNING IN THE UNITED STATES}

"4. The location of public buildings, which may render the conduct of public business convenient or difficult and may give a favorable or unfavorable impression to visitors."

Mr. Edward M. Bassett divides the subject of City Planning into four main heads-first, Movement; second, Zoning; third, Recreation Spaces; and fourth, Public Buildings. Under Movement, Mr. Bassett would include streets, waterways, telephone and telegraph wires, gas pipes, water mains, all placed for circulation and subject to control by the organized community either by franchise or public ownership. Since all these boundaries and utilities can be shown on a map they may be said to constitute planning characteristics of the land. Under Zoning Mr. Bassett would include only those regulations by law which can be indicated on a map. Height of buildings and set back are proper subjects for legal regulations in different districts. The types of architecture, the materials to be used and the color of the buildings Mr. Bassett would not consider to come under zoning regulations. Under Recreation Spaces would fall all of the spaces devoted to public recreation. Under Public Buildings would come not only City Halls and State Houses, but schools, branch libraries and neighborhood public buildings.

There are thus slight variations in the analyses advanced by the different City Planning authorities. In general, however, they are in substantial agreement concerning the subject matter and the application of City Planning.

A recent analysis of city planning, made by George $\mathrm{H}$. Herrold, presents a slightly different alignment.

"The basis of town planning should be: I-Land economics; 2Engineering, and 3-Architectural motif.

"I.-About 40 per cent of the area of a town is, or should be, devoted to streets, alleys, playgrounds, parks and public building sites, all under the control of the municipal authorities. For the other 60 per cent there should be a definite land policy formulated in respect to human relations arising out of ownership and use.

"2.-The fixing of the size and shape of blocks and streets is engineering, as is also the designing of the utilities to serve the different districts.

"3.-Architectural motif is only controlled, if controlled at all, by a building code. Building codes should be broadly standardized and uniform for given districts. Good architecture is catching, one beautiful building calls for another. Furthermore there is no better form of advertising than good architecture. ...

"To approach the subject from a somewhat different angle, there are in every town certain areas devoted to the following purposes, i.e.:

"I.-Streets, lanes, alleys, parkways, etc. 
"2.-Retail business, offices and hotels.

"3.-Railroad yards, warehouses and factories.

"4.-Public buildings, town hall, library, schools, fire and police stations, etc.

"5.-Semi-public buildings, colleges, churches, community buildings, public utilities.

"6.-Homes.

"7.-Parks, playgrounds and public squares.

"The arrangement and location of these areas in their proper relation to each other is town planning. The superior location for each one of these uses should be picked out, but owing to lack of knowledge, personal interest, unintelligent selfishness and similar factors there is invariably established in every town a use of property or location of a street in the wrong place. This does not secure the 'superior location' for that use. Buildings may have been put in the wrong place because of a speculative idea that a poor location could be made a superior one by sheer force of will, disregarding all laws of economics and consideration for other people." 


\section{STREET SYSTEMS-LAYOUT}

Every city has started with at least one street if it was only the country highway on which the first houses were built, and most settlements have started at cross roads or where roads met the water. Mr. Frank B. Williams in his book on "The Law of City Planning and Zoning," shows the need for planning from the very beginning. "In the United States," he states, "we are apt to think only of the planning of communities already in existence, and in practice we rarely attempt to guide their growth until they have already attained a considerable size. This is a grave mistake. For good or ill, as soon as two roads of a given width cross at a given place and angle, and a building starts at the intersection, important features of the future community, its life and growth, have been carelessly, perhaps, but in all probability irrevocably fixed." Few towns and cities have had the advantage of being laid out in advance by trained experts. Streets have been laid out none the less, for streets mark the first distinction between the rural cross-roads settlement and recognized towns. The streets may, as in the old New England towns, follow earlier paths; they may, as in the Spanish settlements on the Atlantic and Gulf Coasts, wind their tortuous way between buildings placed without regard to traffic; or they may, as in the vast majority of American towns, form a gridiron or cross hatch. Their direction, their width, and their arrangement are determined by some one. With definite boundaries they are dedicated to public use. The land in streets generally forms the largest and most important property in public ownership. From 20 to 50 per cent of the total area of a city is ordinarily devoted to public streets. 
Except in case of accident to some specific citizen because of the neglect of the responsible officials, however, the joint stockholders in this substantial public property have been singularly negligent in looking after their affairs and in protecting their investment in public streets from the encroachments of individuals or specific groups of citizens.

After the first townsite has been laid out there is a tendency to extend existing streets if the population increases. But literally thousands of "additions," "subdivisions" and suburbs have been planned by owners or promoters, regardless of topography, regardless of existing streets in the main town, and often regardless of the every-day needs of the residents. We all know those awkward jogs and those dead-end streets which result from patching together various areas laid out at different times, with streets running at different angles and at different intervals. Such street combinations do not make good arterial traffic ways.

Miles of New Streets.-We should not underestimate the miles of streets which have actually been laid out and built during the last thirty years to accommodate the increase of thirty-two million people over the twenty-two odd million people who lived in towns of 2500 or more in 1890 . Not every town will become a city, but in the last thirty years a good many towns have become cities. The 25,000-to-50,000 class has grown from 66 to 143 towns; the 50,000-to-100,000 class from 30 to 76 cities, the 100,000 -to- 250,000 class from I 7 to 43 cities; the 250,000 -to-500,000 class from 7 to 13 cities; and the 500,000-and-over class from I to 9 cities. It is not necessary to base street plans on the boosting claims of promoters. Population estimates based on probability trends can easily be secured. Indeed careful studies can be made by those who know how, which will forecast quite accurately the future development for a period of years, and it is quite possible to devise a street system which will meet immediate needs and still be flexible enough to serve the more-or-less distant future. There are, of course, certain proposals for various formal 
geometric or concentric street systems; but each specific situation offers such diversity in topography, geography and other land conditions as well as in social, economic, industrial and commercial customs and conditions that it is not much more sensible to recommend a ready-made street system for a particular town than it would be to prescribe a patent-medicine dose for all patients, regardless of the disease.

Radial Growth.- "The natural growth of a city is invariably radial, pushing out in every direction from a common center, unless some unsurmountable obstacle prevents," says B. A. Haldeman. "This is a law of communal growth as old as civilization itself, yet the builders of cities, particularly of American cities, have persistently ignored it and have permitted cities to expand mile after mile beyond the common center apparently without sufficient breadth of vision to see that all expansion contributed to the importance of the center and to the concentration there of all the public, quasi-public, and even private activities which come in official, business or social touch with the entire community, and without any effective measures to satisfy a constantly growing need for larger, quicker and more convenient means of intercommunication. Indeed, it has often happened that direct routes which grew up naturally while a district was rural or suburban have been abandoned or obstructed in the spread of urban improvements, and have been superseded by a system of streets projected with the sole purpose of developing private property."

The principal arraignment of the unmodified checkerboard street system is not that it is monotonous, though it is apt to raise monotony to the $n$th degree, or that straight streets are not suitable for municipal development, for some of the most famous streets in the world are level, broad and straight, but that it does not recognize the fundamental principle that a street should go from somewhere to somewhere. In the checkerboard plan the two main axial streets which cross at the center of town may, and often do, lead directly to "somewhere" to which the city crowds desire to go. But for the 
large squares which lie between these axial streets and the municipal boundaries, all traffic must "tack" either making many turns or one turn, but in either case traveling an unnecessary distance. Reduced to terms of time and then to terms of money for use of men and equipment, the checkerboard street plan of a large city becomes an increasing expense to its citizens as traffic becomes more congested.

City planners, therefore, find themselves obliged to consider the direction of the main lines of traffic. In the city already in existence these main streams of travel are fairly well established, though they may change and shift somewhat from generation to generation; but, unfortunately, the street system is not always adapted to carrying these traffic streams. Many cities have widened business streets or at great expense cut through entirely new traffic streets.

Arterial Highways.-Every sensible street plan for a populous city is built around certain broad arterial highways to provide for the main traffic streams in and out of the city and for certain cross-town, by-pass, or circulatory avenues which will distribute the traffic by convenient routes.

It is not enough to piece together the local streets which are laid out from time to time to serve certain neighborhoods. Modern traffic tends to flow into direct, wide, smooth highways. If these do not exist, the circulation of a city is clogged. Moreover, much unnecessary congestion results from forcing all kinds of traffic through a bottle-neck or into a small, crowded center, if its destination is such that it can be distributed before it reaches the point of the needle.

We all know cities in which farmers' trucks from the country, motor transports from the neighboring metropolis, heavy vans from the freight yards, merchandise delivery wagons, passenger vehicles and street cars must all pass some central circle, square or corner because the street connections meant to serve the public are such that all down-town traffic is borne, unclassified, unsorted and undistributed, to the center of town. This kind of an arterial street system has given many of our 

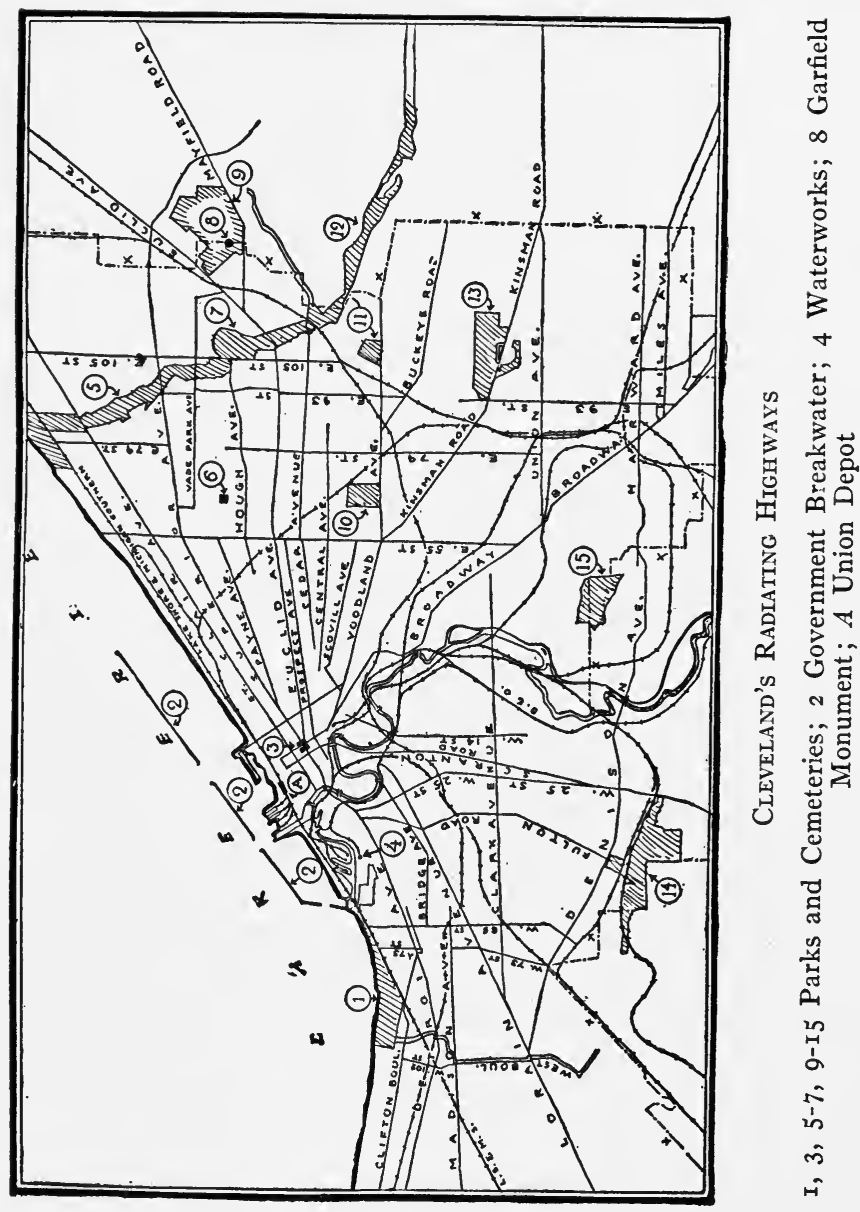
cities such a high blood pressure that they have been obliged to call in a physician, not a general practitioner, but a specialist-the traffic engineer. The traffic engineer must ordinarily accept the streets as they are and try by various devices to increase their usefulness. But in many cases an adequate arterial system would have served as a preventive measure.

Even the simplest two-way approach to a town forms the back-bone of a future arterial street system. But most towns have approaches from many directions. Boston on its terminal peninsula may be approached by land from radiating spokes covering about four-fifths of the circumference of a cart wheel. There are about eight main traffic streams flowing into the city, but the traffic of many branches is concentrated into at least five of these main spokes which tap the thickly-populated surrounding country.

In Baltimore the narrow, country roads of the old town became in time city streets and furnished diagonal thoroughfares which the rectangular street system would never have provided. From the northwest came the Liberty and Reisterstown roads; from the northeast the Harford and Belair roads, and from the southwest the Frederick and Washington roads, now all too narrow to bear the tide of freight and passenger motor cars which floods into Baltimore. But these old roads, with the old York pike, from the north, form seven spokes in the arterial wheel, as yet imperfectly connected by circumferential roads, but fortunately for the crooked, narrow lanes of the down-town section, North Avenue furnishes a broad by-pass around the central part of the city for the through traffic between New York and Washington.

In Washington the Rockville pike from the northwest becomes Wisconsin Avenue, the Bladensburg Road from the northeast joins Maryland Avenue, the Benning Road joins Florida Avenue. Maryland Avenue, falling within the L'Enfant Plan, is wide enough to carry the present-day traffic, but Florida Avenue, which was the old Boundary Street, is easily lost in the maze of awkward street joinings of the old and the 
new street systems. Wisconsin Avenue now has become the main thoroughfare by which all the through motor travel from the west is routed into Washington, and it has been necessary to widen the traffic way to accommodate the great numbers of passenger and freight automobiles which come from far and near.

Chicago has been forced to widen Michigan avenue where it crosses the Chicago River, and there is an extensive streetwidening program in prospect to provide an arterial system of sufficient capacity to serve the city's needs.

Los Angeles is spreading like a young octopus over the map of Southern California, but it has not yet succeeded in piecing together an arterial street system to bind its own tentacles, much less to care for the constant stream of tourist and freight motor travel which threads its way in and out of the thriving metropolis.

San Francisco on its isolated peninsula has tunneled under Twin Peaks to give more direct access to the territory beyond.

Boston is planning an intermediate circular thoroughfare to relieve the pressure on the inner and outer by-pass connections.

The importance of planning and building an arterial system of broad highways which radiate from the down-town sections into the residence neighborhoods and into the surrounding country, connected at intervals with wide by-pass streets must be apparent to everyone who has ridden behind a steeringwheel and noted the traffic flow in and out of any of our larger cities. But partly because many populous cities have permitted their broad acres to be covered with high and costly buildings before the citizens discovered the need for such an arterial system, partly because of the incredible housing capacity of these tall buildings, and partly because of the unbelievable multiplication of motor vehicles in which one or two passengers may occupy from I 50 to I 60 square feet of street space, arterial systems which seemed adequate ten years ago are again in the hands of the doctor.

And straightway the traffic engineer, in making his diagnosis, 

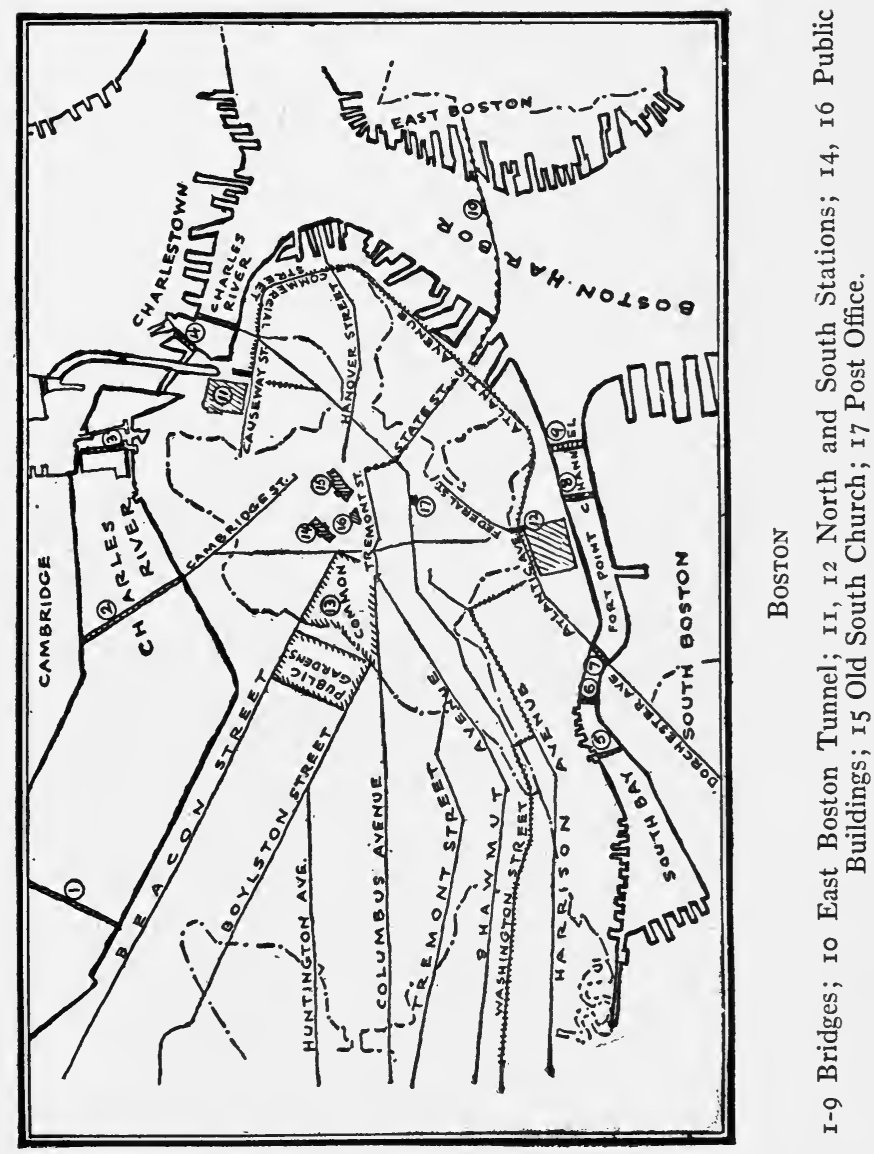
points out that the entire street and highway plan cannot be devised and used regardless of other parts of the city plan. Traffic may be artificially guided by broad, smooth streets to places where it would not normally flow, but the natural location of main traffic streets is closely dependent on the location of the places to which traffic is bound. If, for instance, the industrial section or sections of the city are so located that the main traveled routes between rail freight yards or shipping docks and factories do not cross continuous main streams of passenger traffic, the saving in time, and consequently in dollars, may in the course of years run into considerable figures.

Classification of Traffic.-If the wholesale and retail districts are so arranged that main streams of freight traffic can be sorted from passenger traffic with as few cross-currents as possible many traffic problems will be avoided and so never need solution. If the houses for the workers in industrial sections, whether near or far, are so placed that the multitudes coming by train, trolley, motor busses, automobile or on foot do not meet squarely on grade crossings other multitudes moving directly across the main streams of travel, much time, friction and money may be saved.

There are many reasons for segregating the various types of industrial, commercial and residential areas; but the classification of traffic and its separate routing to the various destinations is not the least of these.

The recent unprecedented increase in automobile traffic has put heavy pressure on main avenues of traffic on which were located interurban or local trolley lines. Rapid transit problems will be discussed later. Suffice it to say here that we owe the width of many fairly broad arterial streets to-day to the space needed for laying tracks. On the other hand, tracks have been laid on streets entirely too narrow to accommodate them with the result that the trolley car and the automobiles, running on the same space, have shared in traffic tie-ups.

Main Thoroughfares.-Mr. Haldeman points out the desirable characteristics of the great arterial traffic ways. "Main 


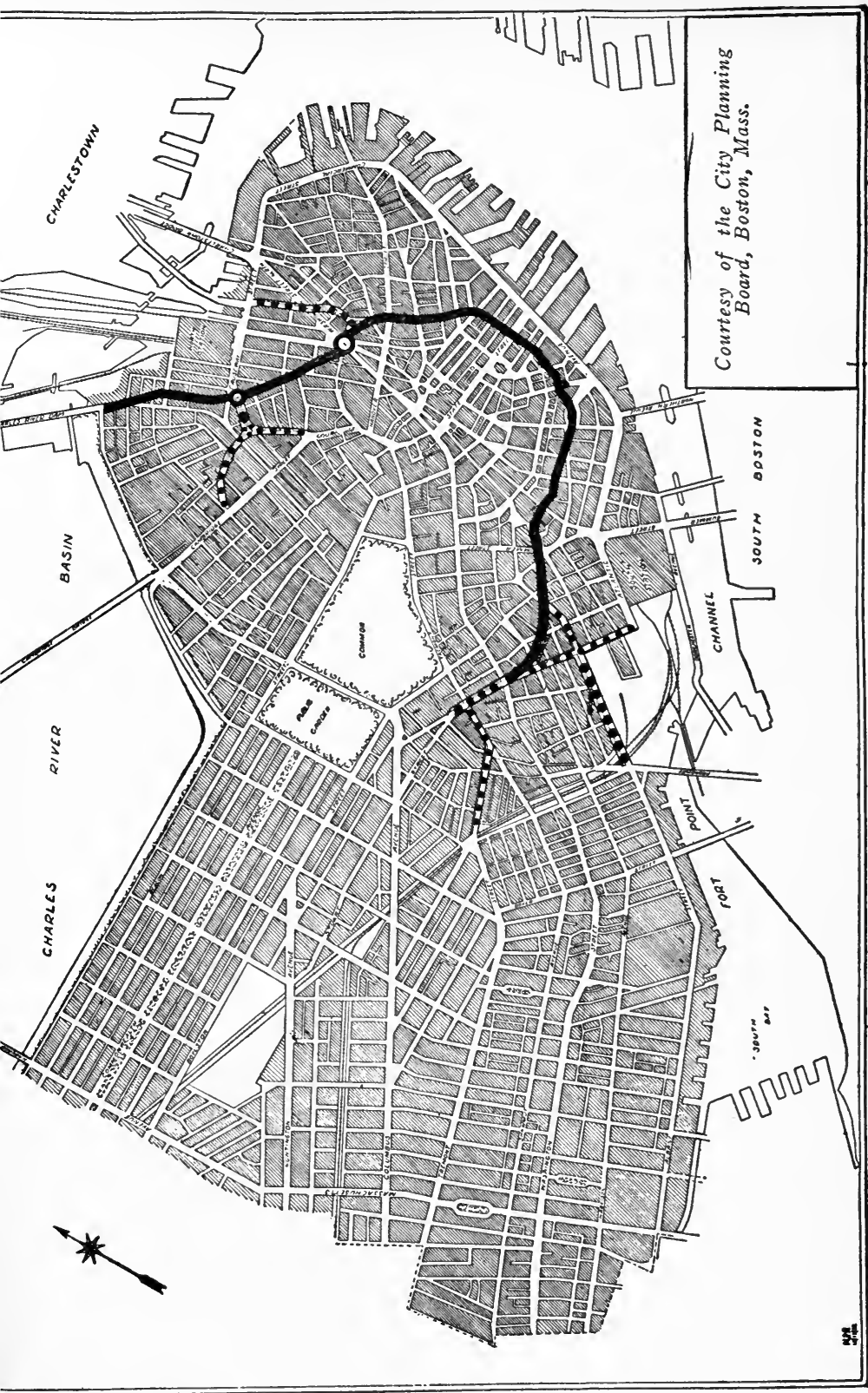

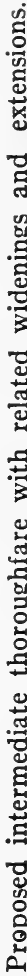


thoroughfares," says he, "should be planned in as direct lines as possible, but they need not necessarily be straight. Sharp curves and sudden jogs should, however, be avoided and changes in direction should be accomplished by means of curves rather than angles, except where the deflection occurs at an intersecting street; a graceful curve or a well-planned fork will tend to break the monotony of long, straight lines. Topographical conditions should not be permitted to exercise as large an influence upon the alignment as in streets of lesser importance. Detours which would materially lengthen the route should be made only to avoid excessive grades; some heavy cutting and filling is to be preferred over many windings in a great traffic route which may be required to carry the trade of a large city for centuries. The first plan of such a street must usually be considered its permanent one, for it is seldom that its capacity can be increased after abutting property has been built upon."

Mr. Charles Mulford Robinson calls attention to the essentials to be observed in the platting of traffic ways in new areas.

"First of all, there must be perception of the town's more important focal points-its waterfront, railroad stations, public buildings, etc.-for the location of these will largely determine those lines of naturally converging travel which ought to define a city's main traffic routes. In the location of these foci there are established the bases from which the street framework is logically built up.

"In the second place, and particularly in sub-division work, we should seek out, with a great deal of deference, the earlier country highways. ... . For these it may be assumed that there was, and is, good reason. Once in a while their grades may be excessive, but generally it is probable that their alignment was sacrificed for easy grades at the time when they were laid out. In the United States, at least, that was likely to be a time when improved country roads were almost unknown, and heavily loaded vehicles were obliged to avoid excessive grades. These existing country roads, even when rectangular in general arrangement, have probably a radial relation to the city nucleus, and may well be taken to form the basis of the extension of the city street system. As existing and natural traffic channels, we may expect streets developed from country 
roads to remain important traffic thoroughfares. As a first step, then, we must widen and straighten these principal channels as hydraulic engineers would do under like conditions....

"If of radial character, our main highways will become farther and farther apart as one travels outward from the center. Doubtless we shall find it advisable, therefore, to branch them occasionally.

"Between the arms of the main framework, thus constructed, it will be necessary to provide cross connections, which in their turn will become main channels for the cross, or circumferential, traffic. ... These circumferential streets will tend, in their turn, to be broad and nearly straight, between the radial or parallel highways. Naturally we shall try to have them intersect those highways at the branching points so that they may serve the largest possible number of people.

"A convergence of radials to the crowded central area of the city-and they must converge there if they are to be of maximum usefulness-will add greatly to traffic congestion, unless the point of convergence be an area of considerable extent. To avoid this difficulty, it will sometimes prove desirable to plan not merely circumferential traffic streets but an inner, or central traffic circuit. ... In practice, on a rectangular street pattern, where the cutting of new streets in the heart of the city would be enormously expensive, the circuit is more likely to be a parallelogram, special width or other treatment haivng been given to four streets which surround the central area and intercept converging traffic at a convenient point. Examples of this scheme may be found in the plans made for Chicago, Philadelphia, Newark, etc. . . .

"In conclusion it may be observed that the system of main highways, if well worked out, will not only constitute the skeleton of the city plan, but that we shall find the principal thoroughfares of the city's outlying portions in complete articulation with the street plan of the inner area."

It is clear that the highways of the arterial system should be broad. Indeed they should, properly, reverse the usual situation, and increase in breadth as they approach the congested centers of the city, in order to accommodate the innumerable subsidiary streams of traffic which they have gathered up. The exact width is a matter to be determined by the population possibilities of the future and by the arrangement of the street. Whatever the width, economy will dictate that it be based on 
multiples of the vehicles to be accommodated, plus the sidewalks and any parking strips. The decimal system of determining street widths from curb to curb involves a waste expenditure of money in so far as it provides extra space not adequate for an extra line of vehicles.

Major Traffic Streets.-After the broad outlines of the arterial system are laid out it will be found that it is necessary to develop a number of major traffic streets. These will generally be the streets which serve the so-called down-town section, though it will be readily apparent that the character of the traffic to and from office buildings, retail merchandise establishments, wholesale dealers and the various types of industrial plants will be widely diverse. Even in the smaller cities there is good reason to segregate, so far as possible, these different types of development. In the larger composite cities segregation is, more and more, becoming a matter of necessity. But whether a given major traffic street is used by street cars, busses, passenger automobiles and taxis to transport human beings or whether it is used by heavy vans, light delivery wagons and other carriers of commodity or whether these are all mixed together, there should be considerable width, less, probably, than that of the main highways, but greater, certainly, than that of the merely local streets.

In the larger cities, during recent years, there has developed a distinct need for developing alternate parallel streets with the arterial highways. The need is often particularly acute when there is a heavy street car traffic, rising to a peak load just as the heavy automobile traffic reaches its greatest congestion. Light passenger automobiles may be easily diverted one or two blocks to smooth streets not blocked with street cars and so give greater dispatch to both types of traffic.

Mr. Warren H. Manning, in his report on the Bangor City Plan, presents a graphic picture of the area brought easily within communication of the business center. In the old days, with horse-drawn vehicles, he computes that the twenty-mile radius brings 804,236 acres within convenient access of a met- 
ropolitan center, whereas to-day the sixty-mile radius brings $7,238,246$ acres within equally convenient access. When we realize that in such populous centers as Boston, New York, Philadelphia and Chicago, a large part of this area is actually occupied by urban developments, we begin to have some conception of the amount of traffic which pours into the downtown sections that serve such stupendous areas and such multitudes of people.

The small rivulets which add their water to the creeks that flow into the branches and then into the mighty rivers contribute to a system of waterways where the river bed becomes ever wider to carry the increased flow of water. It now begins to seem as though the arterial highways as they converge toward the congested centers, even with the aid of underground and overhead transit, could hardly be made wide enough to carry the swollen stream. Certainly many arterial highways are inadequate, and in the existing cities relief is being found in the development of parallel streets in the rectangular networks or in the use of streets heretofore used for local traffic.

In any major street system the by-pass street which diverts out-of-town and suburban traffic from passing through the congested areas to a destination beyond is most important. Chicago is investing millions of dollars to widen the streets bounding a congested parallelogram for this very purpose. Such by-pass streets should be arranged at strategic intervals to connect the main arteries.

Minor Streets.-Even during the comparatively short history of American cities we have seen the development of many fine residential streets-broad, dignified boulevards which, shown on any map, would be seized upon immediately as major traffic thoroughfares and occasionally as main arterial highways. In the smaller cities when traffic of all descriptions was much less than it is to-day these streets were excellent residence streets. But the private carriage and coachman did not serve all the members of the families of those who were sufficiently affluent to afford such a luxury. There was early a 


\section{I LAND PLANNING IN THE UNITED STATES}

demand for public transportation and so, in turn, horse cars, cable cars, and trolley cars were introduced to run on tracks laid in the street.

Business has a certain tendency to follow street cars. Desirable as public transportation is for the residence neighborhood, the noise and jar of the modern heavy street car is considered a nuisance when the tracks run too near to the homes. In most of the United States west of the Allegheny Mountains the "best homes" of a city were placed in large yards, so that the street car did not at first present itself as a "disturber of the peace." But as land values became greater, due in part to the pressure of business, yards which occupied entire blocks or quarter blocks disappeared to make room for business houses and apartments and many famous residence streets of the United States have passed into history or are on their way. To-day we favor residence neighborhoods rather than long residence streets, for only in this way can peaceful seclusion be found.

Therefore the modern city, in addition to its arterial highways, and its major traffic streets, consists of irregular (or regular) networks of minor streets which carry the comparatively light traffic.

Mr. Edward H. Bouton, President of the Roland Park Company, makes the very definite claim that "the only function performed by a street, which could not be as well, and more cheaply, provided for in other ways, is that of furnishing means of circulation-in the form of either through or local travel." As a successful developer of residence neighborhoods, Mr. Bouton has a right to speak with authority. Of the local street, he says:

"The chief mistakes made in the treatment of purely local streets have commonly arisen ... from a failure to discriminate, with sufficient sharpness, between the traffic, in respect of both its character and its volume, to which local streets are subjected.... The result has been a failure properly to discriminate between the necessary requirements of (local streets and thoroughfares).... 
Purely local streets are made unnecessarily broad-which results in a waste of valuable land. Without regard to topographical conditions, such streets are laid down in straight lines, and then, in order to secure easy gradients, heavy cuts and fills are made; such practice not only adds greatly to the cost of grading but it inflicts sometimes great and usually unnecessary injury to abutting property. ... Thus not only are the opening and construction of streets made unnecessarily expensive, but the street plan as a whole is deprived of the attractiveness and interest that arise from variety in plan and from the evidence, where such is shown, of an intelligent adaptation of means to ends.

"Manifestly, mistakes of this character in the treatment of local streets can be avoided only by keeping in mind both the character and the limited volume of the travel that such streets will be called upon to accommodate."

Local streets may well be narrow, should almost invariably conform to the contour, however irregular, and may even lead to dead-ends when ridge land may be developed to advantage by this treatment, though the stranger in the city will desire to see such dead-end streets marked in some appropriate manner. Informal, curved residence streets have the advantage of protecting the homes which face upon them from the noise and dust of through traffic by reason of their layout.

It is admitted that through traffic streets should avoid steep hills. Local residential streets will generally follow contours to prevent the necessity of climbing straight up the sharpest slope of a hill or ridge. The dwellers on a hill which offers fine views and other compensations will not object to fairly steep climbs. Mr. Bouton thinks that gradients of 15 per cent or more for short distances are far better than cuts and fills which destroy the full residence value of the building lots facing on the street, but he warns that gradients as steep as I 5 per cent should not extend for a distance of more than 400 to 500 feet.

But there are degrees of minority in minor streets. There are the residence streets, which by reason of their location, their grade and their width, will never serve any traffic but that destined to and from the houses which for a few hundred 


\section{LAND PLANNING IN THE UNITED STATES}

feet face upon them. Then there are the streets which branch away from the major traffic connections and serve as minor arteries, as it were, to distribute traffic through an entire section. At first these streets may carry little traffic, but as the section builds up they may become fairly important. Occasionally they may carry eventually enough traffic to need a width greater than that of the purely local street. But, if streets in outlying sections are not laid out too far in advance of occupation of the land for building purposes, conditions should easily be foreseen.

On the open prairie the size and scope of residence neighborhoods may be determined only by artificial boundaries; but usualiy there are topographical limits or other obstructions to growth in one direction or another which make sure that residence sections, so far as streets are concerned, may be developed in units which are tapped from fairly important thoroughfares without the necessity for developing local streets which will need to carry a heavy traffic by reason of the size of the territory they serve.

Since local street systems should be planned to fit the conditions which they will need to meet, they should not be laid out until those conditions are more or less determined or foreshadowed. The type of houses, the size and shape of the building lots will vary with different standards of projected development. A street system which would serve adequately a section of large mansions erected on extensive grounds would not serve a development of small houses built on smaller shallow lots.

In the development of suburban residential neighborhoods, as we shall see later, a collection of houses does not make a community. There are certain conveniences which need to be provided for each unit, certain markets and shops, parks and open spaces, schools, libraries, and places of amusement. The predetermination of the location of these various neighborhood conveniences will make it possible to fit the street system to the needs of the community. Frequently the widening of the 
street of main approach to accommodate the special traffic for the length of a single block, particularly to make it possible for the residents to park their cars while attending to their purchases, will serve the double purpose of caring for the local needs and preventing unnecessary interference with the through traffic. In fact, there are innumerable devices to meet special conditions when those conditions are known or anticipated. No device should be copied slavishly. Most good arrangements are worked out on the spot by experts who have studied the local situation and who know how to lay out the face of the earth in streets which meet most or all of the requirements which streets may be made to meet.

Technical Advice.-No longer is every man his own tailor. Neither should every owner or developer of land be his own city planner. The layout of streets is a far more complicated and technical undertaking than the cutting and fitting of a business suit of clothes. Yet many business men who would not dream of appearing down town in a home-made suit of clothes will blithely proceed to lay out a residence neighborhood with home-made streets which will place the development permanently in the amateurish class.

It is too late to remodel the street systems of many of our cities, but the suburban and nearby residence neighborhoods can be laid out by experts in order to give to the future occupiers maximum comforts and conveniences at a minimum of cost. As the public becomes more familiar with the good developments they will be less willing to purchase homes in the poor developments. The time is coming when it will take more than a $\$ 1000$ bathroom in a $\$ 10,000$ house to sell a residence placed on a street so wide that its upkeep, as well as its original cost, is a burden on the owner, or situated on a street which by reason of its length and width attracts unwelcome traffic.

Alleys and Lanes.-There is a great deal of discussionpro and con-concerning alleys. There are those who believe that the alley is an anachronism, that it is simply an invita- 


\section{II4 LAND PLANNING IN THE UNITED STATES}

tion to dirt, disease and crime. There are those who believe that well-laid-out alleys which are lighted and kept clean serve a useful purpose. There can be no doubt that the interior network of alleys which penetrates the blocks of Baltimore and Washington is a liability to the community. The alley dwellings, removed from the protecting publicity of open streets, are a social menace, and have made of the alleys undesirable streets. These alleys are often inconceivably narrow, rough and intricate in pattern. They conform to no standards. They have developed because of a combination of circumstances,too large blocks for the present-day types of building, for one thing. But when one examines the alleys of Roland Park which are dignified by the name of lanes and which offer a service entrance removed from the street, the conclusion is forced that alleys need not be dark or dirty or disagreeable.

But like most other questions of street layout, alleys cannot be considered apart from the whole problem. Underground and overhead utilities can be provided for residence neighborhoods by reserving easements along the rear boundaries if it is desired to remove these from the streets and to eliminate alleys. For this service alone, therefore, alleys are hardly justified.

Moreover, the provision of alleys in commercial sections is an entirely different problem from their necessary inclusion in residence neighborhoods. Where land is covered with high buildings, the fairly wide, straight alley serves to give freight ingress and egress without blockading the sidewalk. Anyone who traverses the side streets in New York's vast business area can hardly refrain from wishing that the metropolis had devised some scheme to segregate pedestrians from the boxes, barrels and packages of all descriptions which are constantly being pushed, wheeled or trundled across the sidewalk or eased down into the cellars through open holes in the public footway.

In residence sections which may some day become commercial areas there is much to be said for alleys. In residence sections which may be given over to apartment buildings there 
is something to be said for them. The decoration of the public streets by garbage and ash cans placed on the sidewalk to await the collector is not to be commended. New York has tried night collection to alleviate this difficulty; but the streets of that enterprising city continue to serve a highly unsightly and disagreeable purpose.

In outlying residence developments it is perfectly possible to devise a layout which will eliminate alleys, especially where frontages are sufficiently wide to given entrance space to private garages and to provide screened repositories for garbage and ash cans. In moderate-priced and low-priced developments the elimination of alleys may be advocated if only for the saving in cost. In the case of row houses the elimination of alleys brings more problems, and precludes the private garage except on the cross streets.

In residence neighborhoods where the houses are on a scale which would provide two sets of stairways in the homes it is reasonable to suppose that the owners might care to pay the cost of rear service to the yards, even though it involved the original cost of the land, the cost of paving, sewers, cleaning and lighting.

The conclusions of the eminent landscape architects and town planners who were mobilized to plan the war communities under the direction of the United States Housing Corporation are of interest in this connection:

"The question of alleys caused more discussion than any other one item of general plan. The faults which in the past have given the alley a bad name are principally that it has been a place of concealment on account of high board fences and angles behind buildings, which collect rubbish and which cannot easily be policed; that being partially out of sight and often not under public control its paving and general construction and upkeep is neglected and apt to become insanitary and otherwise defective, tending to infect the neighborhood with a spirit of neglect and disorder; that when land increases in value there is a temptation to turn the alley into a low-class residence street, with all its attendant disadvantages. If for practical reasons of access to the backs of houses an alley is needed, it is plain that all the above disadvantages can be over- 


\section{6 LAND PLANNING IN THE UNITED STATES}

come by enough expenditure in construction and upkeep. We started with the attitude that since alleys were an extra expense we would not use them unless they were plainly needed, but that if we used them they must be publicly owned and sufficiently paved, lighted and policed.

"This meant that we would not construct alleys in a town which would not accept them as public ways. ... We required, further, in most cases that all parts of an alley should be visible from either one end of the alley or the other at the street, that alleys should be $\mathrm{I}_{4}$ feet wide, and that no board fences or other solid screens should be built along them. Except where alleys were forced upon us by a pre-existing street plan or by municipal ordinance they were introduced only where they appeared necessary either as a means of access to the rear doors of row houses or in a few cases as a means of access to garages not accessible from the fronts of the lots. When provided, alleys were also used as locations for electric pole lines in order to keep the latter off the streets as much as possible.

"In most cases where the construction of alleys appeared to be unnecessary and inadvisable, easements were laid out for carrying the pole lines through the interior of blocks. Such easements, restricted against occupation by buildings but not open to public travel, are capable of being converted into alleys and opened to traffic at some future time if necessary; but in the absence of an insistent public demand for alleys, the land covered by such easements is more useful and far better kept if treated as a portion of the individual back yards than if set apart as a strip of no-man's-land like the ordinary suburban alley."

General rules on the subject of alleys are apt to be inapplicable in specific instances. Many municipal ordinances requiring standardized alleys would be unnecessary if the city had a competent plan commission with a technically-trained city planner on its staff. Alleys might well be desirable in some parts of a city and undesirable in others, whether by reason of topography or in order to save the expense. But in a standardized street system it would not be the part of wisdom to omit alleys by the hit-or-miss plan. The different sections of the city should be laid out as units, and if alleys are to be omitted provision should be made so far as possible for the conveniences which are ordinarily provided by alleys. 
Footways.-In many residence developments, and occasionally in commercial sections, particularly where the topography is rough, it will be found advisable to provide public footways for pedestrians which are not paralleled by vehicular traffic. The use of these, however, is nearly always dependent upon special conditions. The public footway should not be forgotten as a means of solving some of the problems of layout.

Pleasure Roads and Boulevards.-Before the advent of the automobile the public parks of cities, when they lay on the outskirts, were supplied with a few driveways. Druid Hill Park in Baltimore, Cherokee Park in Louisville and Golden Gate Park in San Francisco had developed drives within their borders. But the extensive use of pleasure automobiles has stimulated the securing of larger park areas and the laying out of pleasure drives. The inner and outer park systems of many cities are connected by a series of parkways or boulevard drives. In the metropolitan district of Boston there are many miles of driveways bordered by grass and trees on strips of varying width which connect the system of country parks scattered over the map with a prodigal hand. On many of these drives appears the sign "For pleasure vehicles only." In other words, heavy freight vans, and consequently slowmoving traffic in general, are excluded from these scenic roads.

The rigid street plan of Chicago prevents the charming informality of the Boston pleasure drives; but Chicago has developed its boulevards and the Lake front furnishes a graceful line which the man-made street system denies. The park-topark boulevard connections of Chicago are further relieved by the winding driveways constructed in the larger parks by which the pleasure traffic is conducted across these areas.

In New York the Bronx Parkway is providing an excellent pleasure driveway which will connect in time with the Interstate Palisades Park by a bridge across the Hudson River.

More and more the demand will stimulate the creation of pleasure driveways, bordered by parked strips, connecting 
small and large parks into a system and providing for a comparatively recent form of outdoor recreation.

It is apparent, however, that these extensive park systems, together with their connecting parkways, should be planned to articulate with the city plan as a whole. Nearly every townsite has within it certain ravines and small streams even if it cannot boast of a wide river or high hills. In the plains cities, often the only natural irregularity is to be found in these stream beds. These valleys are natural sites for parks and parkways. A careful study of the topography will often develop enough "natural sites" to supply the intervening areas with the informal parks and parkways. If this is not the case such parks and parkways can be located arbitrarily. But in either case the early development of the rough outlines of a park system which will provide pleasure drives within and without the city is quite as essential as the blocking out of the main arterial street system. Since the two should supplement each other, and since the two systems cannot make a main traffic highway and a pleasure parkway occupy the same space at the same time, it is evident that the plans for both should be harmonized and unified, in order to offer the highest degree of service to the community as a whole.

Not the least advantage of the pleasure driveways is the automatic segregation of traffic which is involved. By removing many of the lighter and faster-moving vehicles from traffic arteries which parallel, more or less, the parkways, they give expedition to both classes of traffic. This adds to the efficiency of the street system as a whole.

\section{SUGGESTED READING}

B. A. Haldeman, "Transportation and Main Thoroughfares and Street Railways," in City Planning, XIII, p. 29I; edited by John Nolen, National Municipal League Series.

E. H. Bouton, "Local and Minor Streets," in City Planning, IV, 88; edited by John Nolen, National Municipal League Series.

United States Bureau of Industrial Housing and Transportation, Report of the United States Housing Corporation on War Emergency Construction, Vol. II, p. 78. 


\section{STREET SYSTEMS-WIDTH AND ARRANGE- MENT}

Streets not only have length and direction. They have width. But width cannot be discussed with any degree of accuracy except in relation to the arrangement of the facilities provided for the different purposes to which streets are put. Those who had observed the inconvenience of many of the narrow down-town streets in the early eastern cities went rather to the other extreme when they planned many of the later western towns. Excessively wide streets were often laid out, and when asphalt pavement became the pride of the modern metropolis these broad streets were covered from curb to curb with a pavement which cost the taxpayers per square yard a very handsome price. A better and more economical arrangement of the space could have been made.

The official width of streets and public highways runs from private boundary to private boundary of abutting property. In commercial areas, this ordinarily means from building line to building line. Streets thus include the sidewalks, the grass strips, if any, the curbs, the gutters, and the space for vehicular traffic.

Encroachments on Public Streets.-Public ownership of streets has not always been clearly understood and appreciated by the citizens. In granting franchises for street car tracks the rails have not always been placed in the location which would best safeguard the total volume of traffic. But the surface of streets has been far better protected for public use than the air above and the ground beneath. Overhanging signs, networks of wires, unwarranted encroachments of projecting 
steps, show windows and various methods of displaying merchandise became in time an actual menace to the passing public. In most of the larger cities, the overhead wires have been placed below ground, the overhanging signs have been greatly restricted or abolished altogether. In most cities, too, encroaching steps and show windows have been pushed back to a building line which allows the public the full use of the public sidewalks. Most building codes permit certain projections beyond the building, but these are usually of a character which, in theory at least, will not occupy the space owned and controlled by the public.

It was not unnatural that these encroachments should have grown up in years when the space devoted to the public streets seemed all too generous and during a period when the public had not been thoroughly awakened to its responsibilities as a property owner - a shareholder, as it were, in a business enterprise of some magnitude.

During the years when these encroachments by franchises for public utilities and by permits to private commercial establishments were developing into a recognized abuse, there was another form of encroachment upon the public property in the street which was seldom observed. This was the building of cellars, basements and vaults below the sidewalks for the use of private owners. These uses of space belonging to the public have prevented the laying of underground utilities in the very place best suited for the purpose. Gas pipes, electric wires for various purposes, and frequently water pipes may be laid under the sidewalks where they may be reached through manholes and repaired easily without interfering with the vehicular traffic. It is now coming to be a recognized principle that the space beneath the public sidewalks belongs to the public and should be used only for purposes which may fairly be considered public.

It may be remarked in passing that the private use of the space under the sidewalks has led in only too many instances to the premature destruction of street trees. Many business 
streets in Washington are still provided with street trees, though these must struggle against very unpropitious growing conditions; but the line of trees is broken in many instances by the building of basements which extend under the sidewalk and make it impossible for any tree to nourish its roots.

Few cities have regained entire control of the space in their streets, for present-day officials are bound, in many instances, by franchises and permits issued by their predecessors. But the principle of public ownership of the street, surface, air space above and ground beneath is coming to be quite generally recognized and the old errors are not likely to be repeated.

Proceeding, then, upon the theory that the public may control the entire space, we may discuss the various arrangements of that space to meet the different uses to which streets are dedicated.

Street Widths.-In I9I I, Dr. John Nolen called attention to the importance of fixing street widths more intelligently and discriminatingly than had been done in the past. With some of our streets too narrow and some of them too broad and most of our municipal laws providing for standardized street widths fixed without relation to the traffic possibilities, there was need for revision of methods of fixing street widths. Dr. Nolen estimated that at that time the total area of cities devoted to street purposes averaged from 20 to 40 per cent, with 54 per cent of the area of Washington, D. C., given over to streets. In comment upon the balance between extravagance and economy, Dr. Nolen remarked:

"Consider what an excess of two feet in the width of the fourteen hundred miles of paved streets of Philadelphia would involve in the cost of land and paving! On the other hand-and here the lack of intelligent and discriminating action has even graver aspects-consider what the lack of a few feet in the width really necessary for streets in Philadelphia already involves! It involves directly the expenditure of enormous sums of money for street widening, or, indirectly, of much greater sums, practically incalculable in amount, as the penalty for conditions which still appear to our too timid minds virtually unchangeable." 


\section{LAND PLANNING IN THE UNITED STATES}

Discarding as unscientific the decimal system of regulating street widths - that is, fixing forty, fifty or sixty feet as the width for the different classes of streets-Dr. Nolen sets forth the following principles which should govern the determination of street widths:

"(I) The width required for a 'line of vehicles,' thus fixing roadway units; (2) the width required for a 'line of pedestrians,' thus fixing sidewalk units; (3) the classification of the streets of a city according to the traffic requirements put upon them, or the other functions that they are to serve; and (4) an estimate of the present and future traffic of the streets of any given class, the width required to meet the traffic, and then the standardization of that width."

Mr. Nelson P. Lewis believed that "standards for the subdivision of street widths are undoubtedly desirable rather than leaving these details to be fixed according to the whim of the developer or the notions of the engineer in each particular case," though he thought that the "standards adopted have not often been the result of a careful study of the needs of traffic of the various classes."

Dr. Nolen presented three illustrations of space needed for different classes of traffic which are in substantial agreement with estimates made by other writers.

"I. An average main thoroughfare is to have, say,

A double track car line.......................... 20 feet

6 lines of vehicles, 3 on each side of tracks, $8^{\prime}$ ea........ 48 "

20 lines of pedestrians, to lines on each of the two sidewalks, $\boldsymbol{2}^{\prime}$ each......................... 40 "

Total for an average main thoroughfare........... ro feet

"II. An average secondary thoroughfare is to have, say, A double track car line........................... 20 feet

4 lines of vehicles, 2 on each side of tracks, $8^{\prime}$ each...... 32 " r6 lines of pedestrians, 8 lines on each of the two sidewalks,

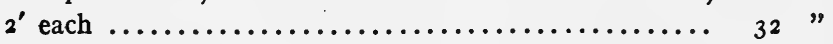

Total for an average secondary thoroughfare......... 
"III. An average local street is to have, say,

Roadway for 3 lines of vehicles, 8 feet each............ 24 feet I2 lines of pedestrians, 6 lines on each of the two sidewalks,

$2^{\prime}$ each $\ldots \ldots \ldots \ldots \ldots \ldots \ldots \ldots \ldots \ldots \ldots \ldots \ldots \ldots \ldots \ldots \ldots, 24$ "

Total for an average local street.............. 48 feet

"These are only averages and are given simply as illustrations of the method of standardization proposed and its application. The range of street widths for such a classification might be as follows:

"Main thoroughfares.....................90 to I80 feet

Secondary thoroughfares................60 to 90 "

Local streets.........................40 to 60 "

This discussion admittedly made no mention of grass strips or space for street trees. This space must be added to the traffic spaces. In formal streets the width of strips required for certain varieties of trees may be more or less standardized, though in many cities far too little space is provided for trees. In arranging informal streets to conform to topography or laying out streets in residence neighborhoods there is no reason why the grass strip should be of uniform width. The parkway strips connecting the outer park system of Boston present an exceedingly interesting appearance by means of such an arrangement which gives an effect of natural landscape.

Arrangement of Streets.-It is obvious that on some main thoroughfares there will be heavy vehicular traffic and only moderate pedestrian traffic; on others the pedestrian traffic will be important. These facts should influence the width to be devoted to these purposes. In certain down-town sections in some cities the vehicular roadway has been widened by making the sidewalks narrower. In a recent instance in Washington this has resulted in the cutting of well-established street lines. The wider street now provides for diagonal parking of automobiles in addition to the moving vehicular traffic; but as the street is in a retail section, the replacement of many of the small two- and three-story buildings by modern structures of larger capacity together with provision of down-town parking 
garages may increase the pedestrians and decrease the vehicular space required so that the original arrangement will be better fitted to the conditions. By that time the street trees in their new positions will have become established. Undoubtedly, however, the distribution of width to the various functions of a street will need to be changed as conditions of occupation change.

The fact is that in most of our larger cities the width of the down-town streets is fixed so that only in the case of dangerous congestion which offers no other apparent solution can the street itself be widened. Heights of buildings have added greatly to the traffic of a given street in lower Manhattan, in the "loop" section in Chicago, in the retail and office district of Los Angeles and in other cities. When these streets were laid out no such buildings as the modern skyscraper were contemplated. If it were known (as it usually is not) that a new town, laid out to-day, would become a large city, it is at least an even guess as to whether the down-town streets would be made very broad or whether more streets would be provided with less space between.

Business Streets.-The arrangement of down-town streets in cities in the United States has become somewhat standardized. Street car tracks are here usually laid in the middle of the street. The vehicular traffic occupies the space between the car tracks and the curbs. Indeed, in most business streets, the space between the tracks is paved, and automobiles and motor trucks use the space between the tracks as well as that outside. The sidewalk usually runs from the curb to the building line. In all too few of the larger cities are there any grass parking spaces or trees in the business section. Washington is an exception to this rule, but the concrete is gradually overrunning many of the grass strips and spaces for trees.

Even in the most crowded sections this arrangement is varied by open squares, small, irregular spaces, circles, triangles and, more rarely, by central parkways. These were usually dedicated to public use before ground became valuable 



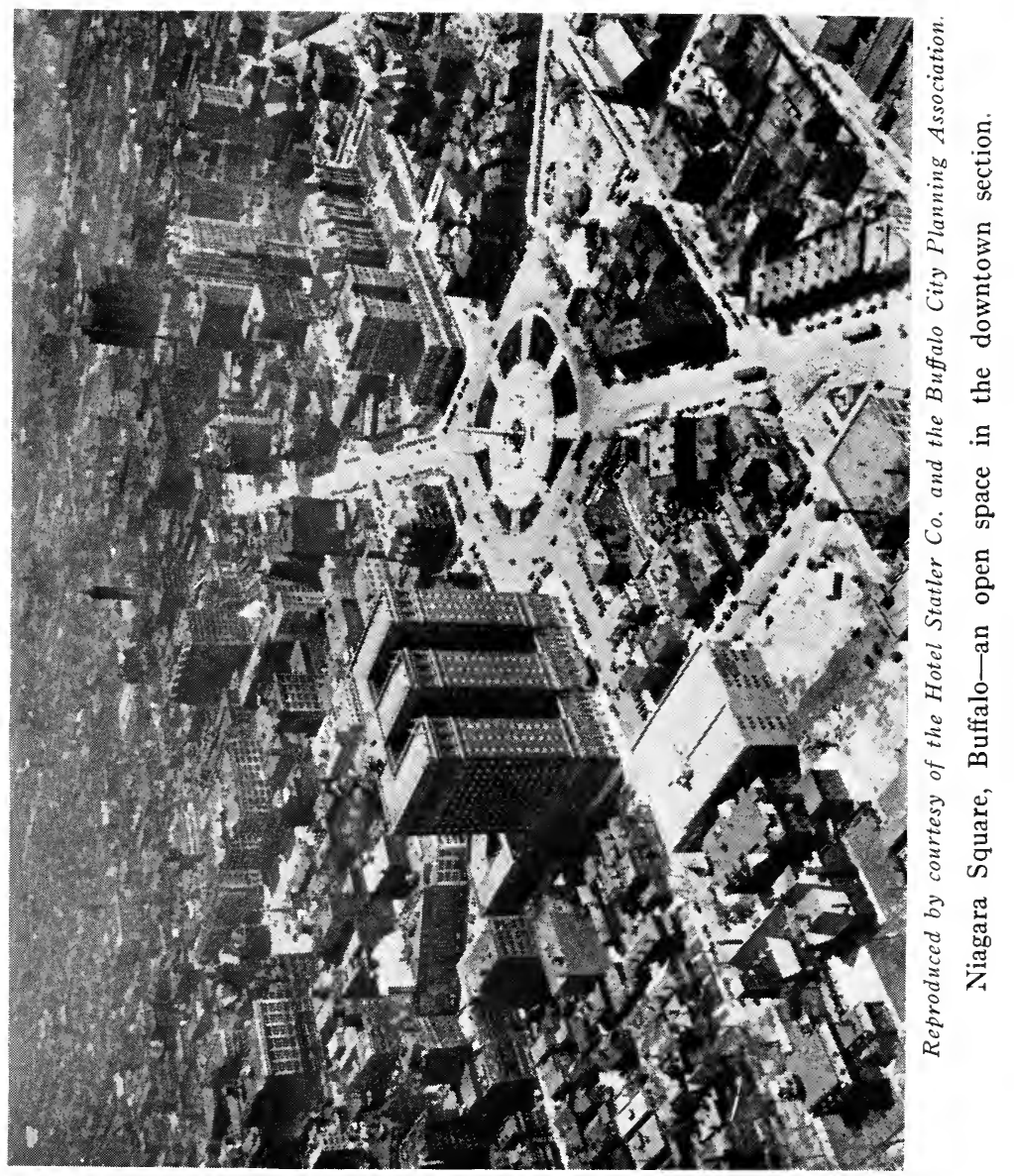


or when the section was used for residences; but they form, to-day, welcome oases in the desert of asphalt and concrete, and, for short distances, they frequently determine the arrangement of the street. If the space is small, traffic is usually routed around it in a one-way stream, sometimes with a sidewalk on either side of the vehicular space, but more often with the sidewalk only on the building side of the wheeled traffic.

Residence Streets.-There is greater variation in the arrangement of boulevards, parkways, and residence streets. Street car tracks, when present, are sometimes placed at the side, and if in the center, are frequently screened by hedges. The space between the tracks in such arrangements is, of course, not used for other traffic and is not paved.

In most residence streets there is at least a strip of grass and trees between the sidewalk and the curb. Often there is such a strip between the sidewalk and the property line. This arrangement provides for a double line of trees which in warm climates offers very welcome shade to the pedestrian. Many streets in Washington are so planned.

Where there is a central strip of grass and trees there may or may not be paths or concrete sidewalks. In many of the wider Washington streets, such as Sixteenth Street or $\mathrm{K}$ Street, a strip of land on either side of the sidewalk is turned over to the owners of houses, who may put it in grass, or flowers or keep it improved in any way approved by the officials; but the land belongs to the District of Columbia and may be claimed at any time for a rearrangement of the street if the conditions warrant it. This method places on the property owners the expense of upkeep, but is generally welcomed by them as it gives them a front yard which they would not otherwise have since it is the custom to build houses on the lot line on these streets.

In the newer residence sections there is a tendency to informality of arrangement. Mr. E. H. Bouton believes that a typical local street in a neighborhood of the better sort should be 50 feet wide, "of which 23 feet may be devoted to drive- 
way, leaving about 13 feet on each side for footway and planting. This 13 -foot space between the curb and the property line will allow for a paved walk $3^{\mathrm{T}} / 2$ to $4^{\mathrm{T}} / 2$ feet wide, a space of $2 \frac{1}{2}$ feet between the walk and the lot line, and from 6 to 7 feet between the walk and the curb for trees and other planting."

But the topography often makes possible irregular arrangements in which there is a sidewalk only on one side or in which the street is on two levels to serve the homes on either side. The traffic on such streets is light, and the convenience of access to hillside land together with the interesting landscape effect is usually considered an asset rather than a liability.

As a final warning against too-wide residence streets let us quote Mr. Herbert Swan:

"Our towns have paid dearly for parsimonious town planning. The price they have paid for street widenings during the last fifty years is enormous. But the cost of widening a few miles of streets which were originally laid out too narrow, fabulous as it is, would look small compared to the value of the land and pavements wasted in miles and miles of unnecessarily wide residential streets."

Street Furnishing.-Consider a residence street, lined by a continuous brick wall of row houses, pierced by windows and doors - the sort which Mr. Lawrence Veiller describes as built by the mile and sold by the foot, a type prevailing in most eastern and some western cities. Imagine every inch of the space from building line to building line covered by concrete sidewalks, curbs, gutters and street pavement. No trees. No grass. Possibly there are leaning poles bearing overhead wires. The familiar green box for Uncle Sam's letters and the smaller red fire-alarm box may be fastened to the wooden poles or mounted on wooden sticks or metal rods. The water hydrant is plainly a water hydrant and nothing more. Under the glare of the summer sun the desolation of such a street must depress the human beings who are obliged to live in it. We have 
only to add an arc light hung by wires stretched from poles at the four corners of the street crossing to throw into sharp

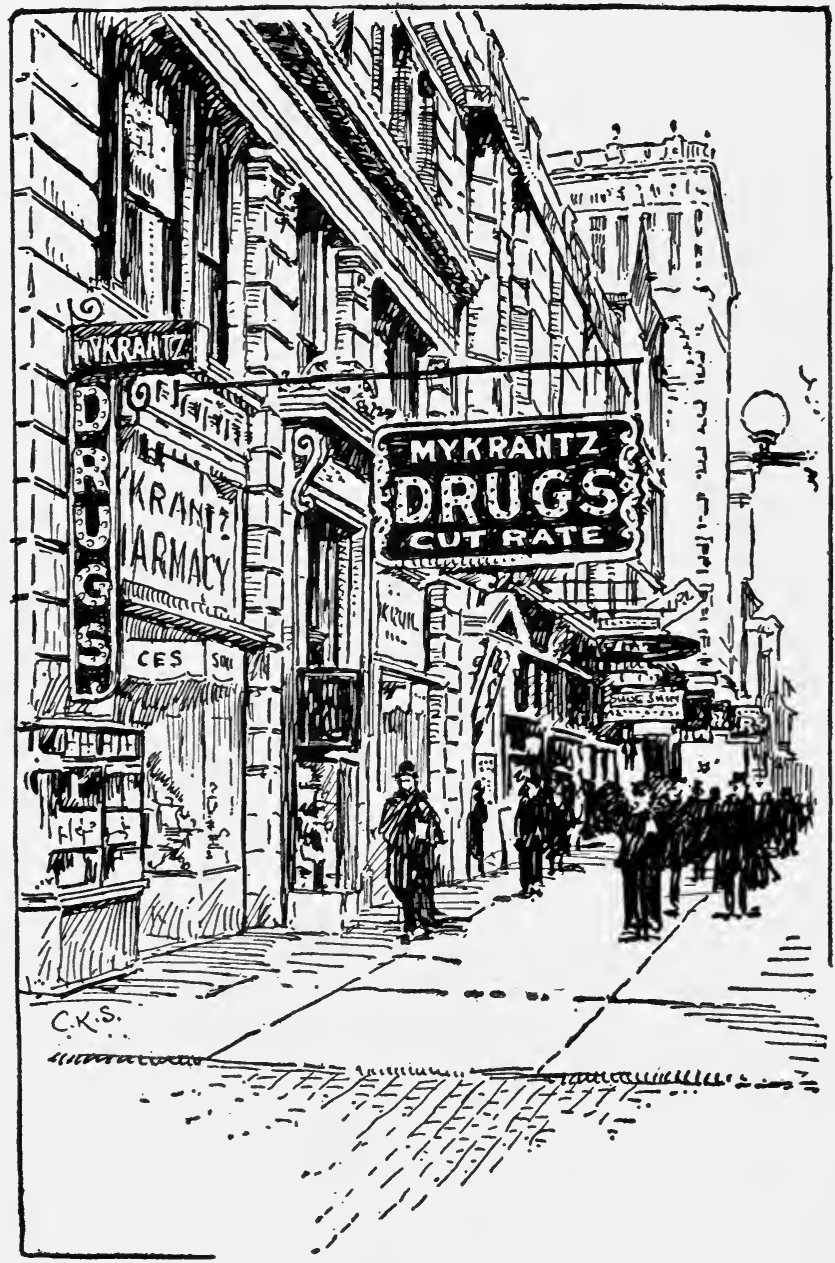

Street with ugly dangerous signs.

relief the stark bareness of the prospect at night. Yet we have all seen just such unfurnished streets. A family sitting room 


\section{28 LAND PLANNING IN THE UNITED STATES}

with bare floors, a deal table, six straight-backed uncompromising wooden chairs and bare walls would provide in the home about as heart-warming and comfortable a place of repose as the street described offers in the way of a hospitable approach.

Contrast with this picture a residence street, with row houses (since apparently we must have them), "set back" far enough from the sidewalk to permit a strip of green and a row of trees. Imagine another row of trees between the sidewalk and the curb. The overhead wires have been placed underground. The street lights are mounted on graceful metal standards and furnish a soft, diffused light. The post, fire-alarm and police boxes are carefully designed and mounted. This city residence street, despite its row houses and narrow frontages, is furnished. In those neighborhoods where the streets lead to houses set in ample yards, the effect becomes more like a park or a garden. And for comfortable, æsthetic homes set in wellplanted yards, facing on just such streets, the American people are each year expending substantial sums of money.

Though the treatment of a business street may not permit green grass and shade trees, the contrast between the furnished and the unfurnished street may be equally great. The character of the buildings facing on the street, the types of signs advertising the wares to be sold, the lighting fixtures, the street signs, the presence or absence of overhead wires, make or mar the appearance of the street and frequently exert a potent influence on property values.

Much progress has been made in recent years in the mechanical arrangements for street lighting, though there is yet a lamentable lack of discrimination as to whether "illumination or advertisement" is the object in constructing a lighting system for any given street. Needless to say, more light is needed in business streets than in residential streets. Lighting fixtures in residence neighborhoods may be placed further apart, and, what is not generally recognized, mounted at a higher distance from the ground, than in business streets. While much 

money has undoubtedly been wasted in the construction and maintenance of "Great White Ways," the modern mazda lamp,

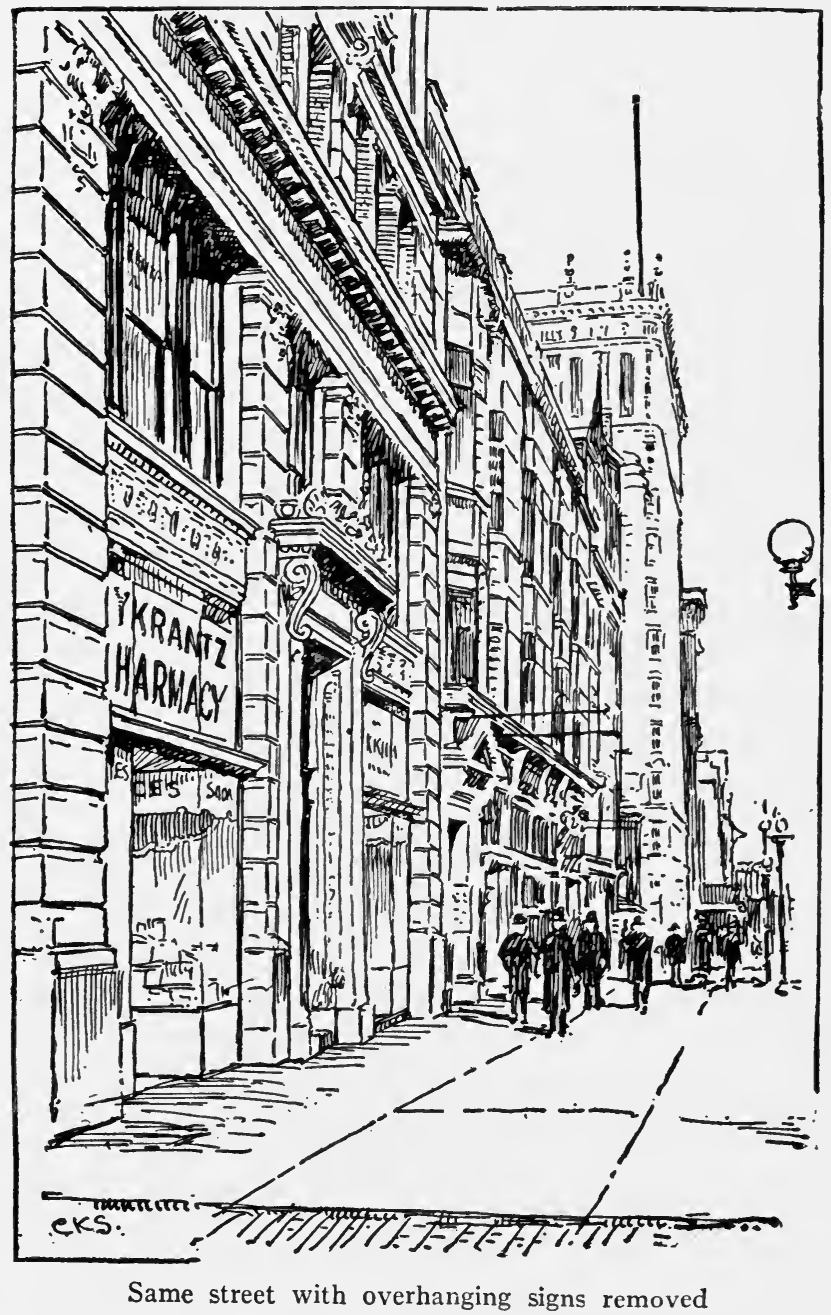

properly supplied with refractors and globes, may be made to provide pleasant and sufficient light for all purposes. Great 
progress has also been made in the designing of lamp posts which add to the appearance of the street.

Closely connected with the lighting system is the method of marking the names of the streets. Many lighting posts are designed to carry the street markers so arranged that the light will make it possible for the names of the streets to be read at night.

Street Markings.-At present in the United States street signs are placed on walls of buildings, on lamp posts, on special posts of their own; they are carved into the curb stones so that the stranger may totally overlook them; frequently they are conspicuous by their absence. The visiting automobile driver, watching for the name of the street down which he is to turn, is not edified to find that he cannot read the name, or, indeed, find it, until after he has passed the turning point. Street signs should be placed where both pedestrians and drivers of vehicles can see them.

There is a great convenience in finding marks on all four corners of any crossing (more if there are more streets) which advertise unmistakably the names of the streets. If this seems too much to ask, there appeared in the American City a few years ago a diagram which city officials may follow with some saving of expense and still render a good service.

Many materials are used, but it is doubtful whether the demands of legibility and durability can be met in any better signs than those of metal with the letters painted a contrasting color on a painted background. Bronze letters on concrete are sometimes used. In residence sections, well-weathered oak boards may carry bronze letters. There is no reason why street signs should be inartistic, but before they are anything else they should be legible from the sidewalk and from the roadway.

Street Trees are probably among the most welcome furnishings which cities may provide. The climate of most of the cities of the United States is such that shade is most grateful for at least several months of the year to those who walk and 
to those who ride. In the cities along the Atlantic Coast the summer heat is a real problem. In the Southern cities the summers are long and the need for shade imperative. The extension of cement sidewalks and smooth pavements and the continuous walls of brick, stone and stucco which border so many miles of city streets, add greatly to the discomfort of city dwellers.

While it is increasingly difficult to provide environment, food and water which will induce trees to grow lustily because of the encroachment of these impervious coverings over the porous soil, many cities have succeeded in overcoming these obstacles. It may be observed, however, that most of the older trees now living spent their youth under better growing conditions than we are providing to-day. Tree experts tell us that it is increasingly difficult to replace dead and injured trees with saplings which will live and flourish, particularly in the areas of high buildings.

"Good shade," says Mr. F. L. Mulford, "is so appreciated that its presence adds a value to adjoining properties. Realestate men recognize this factor and plant shade trees as early as practicable on land which they develop. . . Success in planting street trees can be attained only by planning and controlling the planting as a whole, by selecting the most suitable varieties, by securing trees in the best condition and planting them properly, and by giving the necessary later care."

Washington, D. C., on June 30 , I924, had a tree population of 104,294 stationed in ranks along its streets. It is said that there are more street trees in Washington than in any other city in the world. The sturdy elms of Lafayette Square are centenarians. Those around the Ellipse were planted as part of the plan of Andrew Jackson Downing in I85I. The famous Jefferson poplars along Pennsylvania Avenue, planted because of their rapid growth, have long since disappeared.

The systematic planting of trees on the streets of Washington was commenced in the autumn of 1875 when Governor Alexander Shepherd was guiding the destinies of the capital 
I32 LAND PLANNING IN THE UNITED STATES

city. But the park commission of that day in its anxiety to secure quick results planted many soft wooded trees such a;

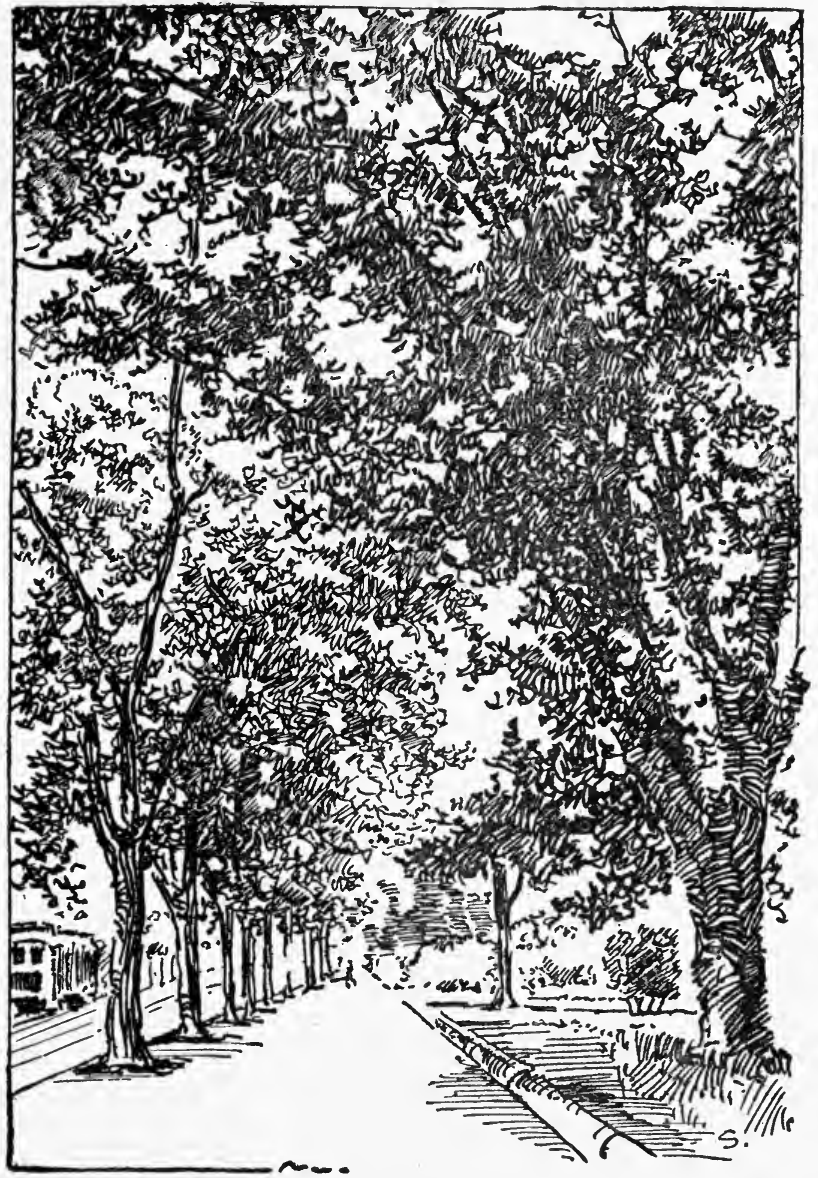

Pleasant vista showing uniform planting of street trees.

Carolina poplars, Lombardy poplars, silver maples and ashleaf maples. Few of these are left to-day. After much experimentation to find street trees best adapted to the soil and climate, new trees are generally confined to American elms, 
American lindens, red oaks, pin oaks, sugar maples, Oriental planes and gingkos.

The reputation of Washington as a beautiful city is due, undoubtedly, in large part, to its trees. In the older parts of the city, where the stately elms form a gothic arch with their high branches meeting over the roadways, many ugly and indifferent houses and buildings are concealed or made less ugly by the green foreground.

Almost any kind of tree is better than no tree at all. In rural settlements and small villages there are frequently to be found fine old trees whose beauty defies the more formal planting of the city. But in communities of any size it is important to plant uniform varieties in regular lines on each side of the street. When there is a row of trees on each side of the foot space, it is not always necessary to use the same variety in both rows. On I6th Street, Washington, which it has been suggested might be called the "Avenue of the Presidents," there are two rows of trees along each side. There are tall tulip trees on the space between the sidewalk and the building line and maples in the space between the sidewalk and the curb. The tulip trees, which reach the third- and fourth-story windows, are not a very clean street tree as they shed blossoms or leaves from early summer to late autumn; but their dark, sturdy trunks and their bright glossy leaves are very effective, and in June, when the yellow blossoms appear, they are most decorative.

In the past it has been taken more or less for granted that in congested business sections, grass strips and street trees must go. One cannot conceive street trees and green grass in some of the narrow caverns between the tall buildings of lower Manhattan. On the other hand, too often we see broad streets between comparatively low buildings transformed from pleasant, tree-shaded roadways into ugly expanses of cement and pavement, unbearably hot in summer in spite of the awnings hung over store doorways-and the transformation effected in the name of Progress! On 15 th Street in Washington, in 


\section{I34 LAND PLANNING IN THE UNITED STATES}

front of ten-story buildings there are tall, graceful elms which make the sidewalks a comfortable promenade in the hottest weather. It is not necessary to sacrifice street trees even in the down-town districts of our moderate-sized cities, if the streets are wide enough and properly arranged.

One of the reasons business men have opposed street trees in down-town areas is to be found in the rather general use of the space beneath the sidewalks for cellars and vaults. If it is once established that this space belongs to the public and can in no case be used for private purposes, it will be possible in many streets to maintain trees in front of commercial buildings. The hotel, the bank, the retail store would, if the proprietors only realized it, gain custom during the hot weather if the street leading to the door were shaded by green trees. In a recent hearing before the Zoning Commission in Washington a number of tenants in a new eleven-story office building on $\mathrm{K}$ Street testified that they took offices in the building because of the street trees and glimpses of grass parking.

But a great deal of time and money has been wasted by selecting poor stock, by planting varieties not suited to the climate or adapted for street trees. The lives of many trees, even when well selected and properly planted, have been lost through nglect. Therefore, it has come to be recognized that "providing shade on city streets is as much a municipal function as providing lights on sidewalks and should, therefore, be cared for by public officials." Trees are a long-term crop. Planted in one generation, they mature in the next and live unto the third and fourth. Policies in street tree planting, therefore, need to be continuous. Frequent changes in responsibility for the trees are dangerous. Lack of funds to keep the trees properly pruned, sprayed and cared for will result in a heavy mortality. The Superintendent or the Tree Commission, if there is one, should make it the particular order of business to look after the appropriations if the tree population is to be protected.

Information may be obtained from the Department of Agri- 
culture in Washington, from the various State experiment stations, and other sources concerning the best varieties of trees to select for the different sections of the country, and concerning the best methods of planting and care. But municipalities should not depend upon laymen for supervision. It is as important to have a Tree Warden who knows about trees as it is to have a highway engineer prepare the specifications for opening and paving a new roadway.

\section{SUGGESTED READING}

JoHn Nolen, "Standardized Street Widths," in Proceedings of The Third National Conference on City Planning, rgr I.

Nelson P. Lewis, The Planning of the Modern City, and Ed., 1922, p. 226.

Herbert S. Swan, "The Thoroughfares and Traffic of Paterson." A Report of the City Plan Commission, 1922.

J. Horace McFarland, "Furnishing the Streets in Suburban Communities," article in Suburban Life reprinted and distributed by the American Civic Association.

J. Horace McFarland, "Illumination or Advertisement," in the $\mathrm{Na}$ tional Municipal Review, Fcb., I924.

A. D. Cameron, "Developments in Electric Street Lighting Units," American City, Feb., I920, p. I35.

"Where Should Street Signs be Placed at Street Intersections?" American City, April, 1920, v. 22, p. 380.

F. L. Mulford, Horticulturist, Planting and Care of Street Trees (Farmers' Bulletin I209), U. S. Department of Agriculture.

Clifford Lanham, Superintendent of Trees and Parkings, "The Tree System of Washington," typewritten Report prepared in I9r 7.

F. L. Mulford, Horticulturist, Trees for Town and City Streets (Farmers' Bulletin I208), U. S. Department of Agriculture. Varieties are described and the United States divided where essentially similar conditions for tree growth exist.

\section{NOTES}

Page I 20.

"Until the introduction of steel-armored and lead-covered cable, it was customary to lay underground cable in conduits, but modern practice favors the use of steel-armored cable buried in a shallow trench below the curb or in the parkway. If properly installed, the life of this cable is almost indefinite, as the lead cover forms an efficient protection from water, while the steel armor protects the cable from mechanical injury." 
Extract from paper presented before the American Society for Municipal Improvements, Baltimore, October, $192 \mathrm{I}$, reprinted in The American City, December, I92 I, v. 25, p. 465. Author, L. A. S. Wood.

Page 126. Concerning the furnishings of streets in suburban communities, Dr. J. Horace McFarland, President of the American Civic Association, wrote an article a few years ago.

"The usual street with a community border," said he, "is broadly divided into two or three portions. The vehicular, or traffic space, so-called, takes the travel of teams and automobiles. The sidewalks, usually on each side, are for pedestrial use. There may be intervening grass plots, or the grass plots may also be between the sidewalks and the property lines, and in them, in either situation, there may be-ought to be-the trees that go so far to make the highway comfortable, beautiful, and permanent. Edging the vehicular division there may be a curbing of some sort, and, if drainage is properly provided for, sewer inlets are also part of the furnishings.

"He would be a curious home-builder who would make his house nearly all central hall, crowding the rooms on either side for that purpose. Yet he would have more reason for such action than there is for dividing suburban streets so as to give by far the larger width to the vehicular or traffic portion. In many cases a suburban street thoughtlessly given up almost entirely to dusty or dirty roadway may well be remodeled, and all proper needs of vehicular traffic met in a much-restricted space. ...

"Now we come to what are actually the furnishings of the suburban street, grouping them into two sections, without a sharp line of distinction. The water-plugs for fire protection, the lampposts for lighting, .... the letter and perhaps fire-alarm boxes, all fall into the section of pure utilities, though all of them may add elegance or ugliness to the street. Fountains, ... public-comfort stations and monuments of various sorts, may make up in general a section of ornamental furnishings, or of utilities that may well be ornamental. Let us consider first the pure utilities and their clothing.

"Many suburban communities have a pressure water-supply, piped through their main streets. If there is also any provision for fire-fighting, there will be water-plugs. Sometimes a combination of an iron founder with an imagination and a painter without one can cause the water-plugs on a street, seldom over thirty inches from the ground, to seem ten feet high and as big as a barrel. It is in order to suggest that the water-plug is never truly monumental, and that it should always be conveniently and unobtrusively placed, being also so painted or bronzed as to blend or harmonize with the surroundings. ...

"The fixtures for dispensing light upon the suburban street have a most important influence upon its dignity and appearance, and usually that influence is not favorable. . . .

"The other utilitarian furnishings of the street are the letterboxes and fire-alarm boxes. The government controls the former, and the latter are only incidentally controllable by the com- 


\section{STREET SYSTEMS-WIDTH AND ARRANGEMENT 137}

munity. Both tend to be ugly, but a careful use of a dull or neutral tint of paint will reduce the damage to appearance."

As for the ornamental furnishings Dr. McFarland urged the formation of art commissions which should pass upon all public monuments, tablets, or works of art, whether purchased or acquired by gift. "Monuments on the suburban street," maintained Dr. McFarland, "may give it great elegance or dignity, or both, or may make it an education in bad taste or mawkish sentimentality." 


\section{TRAFFIC AND THE CITY STREETS}

We have seen that street widths should depend upon the volume of the traffic and that the lane width for the freewheel vehicles is estimated at less than that occupied by vehicles using cartracks. We have observed that there is great variety in the character of vehicles, both in size and in the speed at which they travel. Indeed it was the pressure of congestion in the down-town streets in our larger cities which forced the search for remedies and led to the consideration of city planning principles in whole or in part.

Congestion of Traffic.-The increase in motor cars in the United States from 300 registered in 1895 to more than I8,000,000 in 1925 has brought new problems into the streets. A given length and width of street can clear more traffic which can move at 15 to 25 miles an hour than it can clear at 5 to ro miles an hour if the congestion caused by cross traffic, pedestrian and vehicular, by stopping and starting of public and private conveyances to take on and discharge passengers, and by the indiscriminate mixtures of fast and slow-moving vehicles, is not so great that all the time gained by speed is lost in waiting.

Careful estimates show that the day population of Manhat$\tan$ south of 59th Street, within the two or three hours of the day during which most of the business is concentrated, on a typical business day during 1924 , would approximate $2,4 \mathrm{I} 7,700$ persons of whom 982,000 would be residents remaining in the area or transients. About a third of this total population, then, is contained in the district, less than a third comes from the north, about a fourth from Brooklyn and the rest of Long 


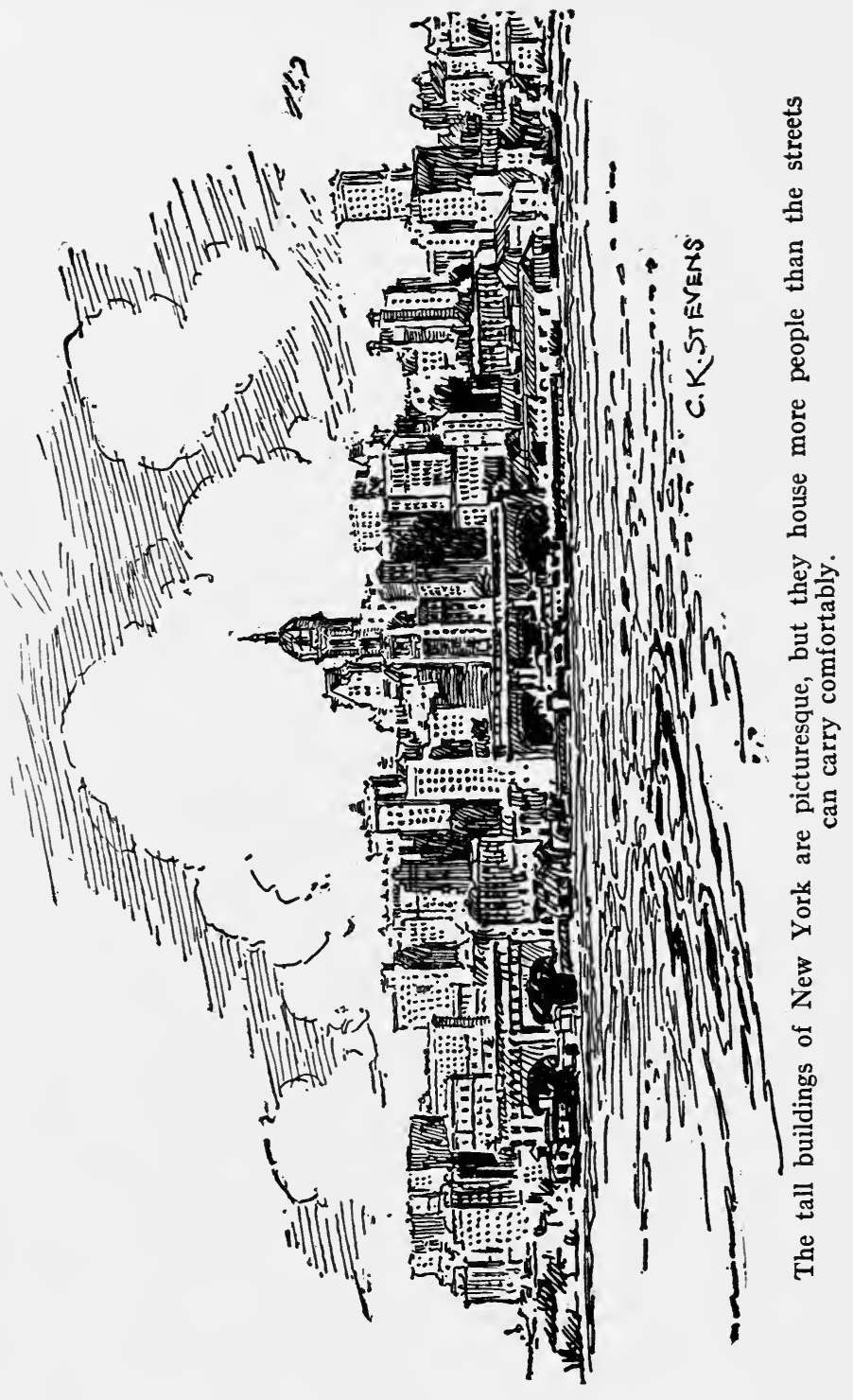


Island, about a tenth from New Jersey and a few from Staten Island. The area of Manhattan below 59th Street is about 8.35 square miles, which would mean that the average density of the day population is $35^{2}, 000$ persons per square mile or about $55^{\circ}$ persons per acre. This is less than one-fifth of the density of the day population of the "loop" district in Chicago, but the New York area is 25 times as large as the Chicago district.

The up-and-down streets in New York are wide, but with the increase each year in the traffic, studies were made to establish a relation between the capacity of any one of these avenues and the traffic which it actually carries.

It is estimated that, allowing for one lane of standing vehicles along the curb, the total maximum possible hourly traffic under existing conditions, on all north and south avenues in the neighborhood of 48 th Street is 29,225 vehicles per hour, or only 125 per cent of the actual traffic in 1923.

Regulation.-Among the measures to relieve traffic congestion, the most generally used is that of regulation-regulation of parking time and control at crossings. "The block system installed on Fifth Avenue and Park Avenue has greatly increased the capacity of those streets," in the opinion of the authors of the New York traffic report, but it "has probably resulted in drawing to them a large amount of through traffic which could be better cared for on other streets." By the development of other avenues by means of smooth surfacing and by regulation it is thought that some of the congestion on Fifth Avenue and Park Avenue could be relieved.

Needless to say, the maximum use of any given street is affected by the rules permitting parking at the curb or the rules prohibiting such parking. Until the traffic congestion forced consideration of the parking question, it was more or less taken for granted that an automobile standing at the curb for any length of time was making a use of a public street which was well within its function. But when the American public became its own chauffeur and left its composite car 
standing all day beside the curb in front of an office building or a retail store, the American business man registered a protest. The street entrance to office building or store was definitely obstructed by such parking; the second line of parking for even a few seconds or minutes to deliver goods or discharge passengers definitely blocks the traffic movement and precipitates tie-ups. When the line at the curb is occupied by the all-day or half-day parked cars, the roadway for moving traffic is definitely restricted and the opportunity to use the curb line for the taking on and discharge of passengers is denied.

It is undoubtedly true that the congestion of traffic in many down-town areas will force long-time parking from the public streets. There are many indications that all parking will be eliminated from principal thoroughfares. But the question of responsibility should be determined soon. So long as public officials seek to find public parking places, private initiative will not build storage garages. But once let it be understood that no parking on the public streets of the down-town district will be permitted, private garages will be built. Frequently large department stores will provide automobile storage for their customers. Numerous dry goods stores are already doing this as a means of drawing profitable customers.

Mr. John Ihlder is an advocate of the principle that provision of parking space may be considered a proper public function, "because it affects the general well-being instead of redounding to the continued profit of easily ascertained individuals." He believes that accessible locations for parking purposes should be secured promptly or at least indicated by city planners before the land is built upon. The maps of the future, in his opinion, will indicate public parking spaces. The movement which is rapidly spreading to provide day-time parking space on the premises or near-by for tenants in office buildings and for customers of retail stores tends toward making a business of day as well as night garages. Co-operative or serviceat-cost garages for day parking are being erected in a few 


\section{I42 LAND PLANNING IN THE UNITED STATES}

cities. In one city in New York State a building devoted entirely to automobile storage makes the most of the cubic space and is enabled to provide down-town "parking" at the rate of $\$ 12$ per car per month.

In the metropolitan areas there is a tendency to break the trip into town by providing garage facilities for day parking at the terminals of certain direct underground or overhead rapid transit facilities into the heart of the city.

Segregation of various types of traffic is suggested as the second remedy - the segregation of through and local traffic and the segregation of trucks and passenger vehicles. Attention is called to the fact that up to the present time the segregation of trucks and passenger vehicles has generally taken the form of exclusion of trucks from certain parkways and boulevards. The suggestion now comes that passenger vehicles should be excluded from certain highways in order to give better dispatch to the movement of goods. It seems that the Port of New York Authority, in its Report of I92 I, indicated a skeleton system for such motor truck highways, using very largely streets already in existence. If such a system were provided with two-level crossings at the principal intersections with other main routes of travel much time would be saved. Indeed, the cost of congestion in Manhattan Island is estimated at $\$ 500,000$ per day.

It is also suggested that segregation might be pushed further-that pleasure cars containing one or two passengers might be detoured by longer routes to provide more space for passenger vehicles like trolley cars and motor busses, "each of which carry from ten to twenty times as many passengers as could the pleasure automobile." There is the suggestion that itinerant vacant taxicabs might be prohibited from "cruising" and instead assigned space for regular stands.

But, considered from the city planning angle, the analysis of the causes of the congestion in New York are quite as illuminating as the proposed remedies and possibly of more service to the many growing communities of the United States 
which are still in a stage of development to profit by the warning of the first city of the land.

The principal causes of congestion are enumerated:

(a) Narrow streets inherited from former times;

(b) Building heights too great for the capacity of the adjacent streets;

(c) The lack of zoning with reference to use, height and bulk of buildings, so as to preclude the creation of traffic congestion caused by the use of the streets by such building tenants, especially at morning, noon and evening hours;

(d) The lack of platting ordinances which would prevent the creation of new subdivisions with streets which are too narrow for their ultimate use;

(e) The inadequacy of arterial thoroughfares both present and proposed;

(f) The lack of a comprehensive plan within which can be included each of the several creative and preventive measures suggested above.

It will be seen that every one of these six causes falls within the city planning field-in other words, intelligent city planning would have saved New York most of the traffic evils which the city is now struggling to mitigate.

It may be observed that the remedies proposed are along the line of making the best use of the present space available in the streets.

Widening Streets.-The most obvious remedy for traffic congestion appears to be the widening of the most-used thoroughfares. But unless this is accompanied by a stringent restriction of heights of buildings, the streets which have been widened at enormous expense are, after a few years, as crowded as they were before.

Two- and Three-Level Streets.-There is no reason to suppose that the limit of this street space, at least on certain main thoroughfares, will not in time be reached unless the height of buildings is restricted much more sharply than there is the slightest promise that it will be. Mr. Harvey Wiley Corbett, a New York architect, has advanced a series of inter- 
esting suggestions for increasing the capacity of the streets. He calls attention to the fact that in the 42nd Street district at the present time there is one acre of street for every two acres of building; but he also reminds us that if every time we take down a four- or five-story building we put up a roor 20-story building in its place, it is idle to suppose that the little 6o-foot street can serve as an adequate supply line for this bulk of building. Mr. Corbett maintains that "rail," "wheel" and "foot" traffic in congested districts do not belong on the same level.

The first suggestion is an elevated sidewalk "carried on a strut a few feet away from the building, cantilevering under the building to carry the load, supporting it so as to permit steps up or down, to adjust the sidewalk level; by this means we have increased the capacity for moving traffic 200 per cent. We only had one moving car where now we have three. And this can be done with only a block at a time."

The rails Mr. Corbett would put underground. Surface cars, he believes, are gradually going out of business for economic reasons. The motor traffic would remain on the surface. When this space is all used Mr. Corbett believes that a law might be passed requiring property owners who wanted cars to park in front of their property to provide the necessary space within the building line. This cannot be done to-day because the cars would then have to cross the sidewalks; but with the sidewalks lifted, it would be comparatively simple to provide parking space within the building line on private property.

By carrying these elevated sidewalks across the intervening streets, "so that the people could move unobstructed through the whole shopping district, separated and free from the traffic," Mr. Corbett claims that the "occupation of walking would become a pleasurable pastime instead of a hazardous adventure as it is now."

Pushed to its ultimate conclusion, Mr. Corbett sees New York developed in its down-town section with arcaded side- 
walks on the second level within the building line and with space for one moving and one standing vehicle on the surface within the building line so that motorists and pedestrians can reach stores and office buildings in comfort and safety.

"Imagine," he asks us, "the future city as a sort of modernized Venice-a city full of canals and bridges (arcaded sidewalks) where the people walk protected from the heat of the sun and from the rain and snow-free and undisturbed by traffic conditions. The canals instead of being full of water, however, are filled with motors-a flowing tide of motors instead of the river, with the pedestrians looking down from above. The solid wall bridges would close off the effect of the traffic and you would have a city more ideal architecturally speaking, and more practical from the point of view of the inhabitants, than anything the world has ever known."

For some time it has been perfectly clear to students of city planning that heights of buildings must be limited drastically or that street capacity must be increased by developing more than one level. There are those who advocate decentralization by holding down the capacity of the buildings and there are those who hold that the skyscraper makes possible a desirable concentration for the transaction of business and that the street capacity can be developed without mechanical difficulty. But both skyscrapers and two- and three-street levels mean large expenditures of money and may be expected to occur only when intensive use of land has developed high values. The smaller cities and towns will content themselves with spreading over the surface of the land and meeting their problems on a horizontal rather than a vertical plane.

Decentralization.-Mr. Raymond Unwin, the distinguished town planner, has made careful estimates of the amount of space, both roadway and sidewalk, and the time required to clear foot and automobile traffic from a single skyscraper building in New York. One can only marvel that the crowds are moved at all and one can hardly escape the prediction that the traffic congestion will force lower building 
heights or multiple street levels. Of the two alternatives decentralization seems to offer the less expensive and more satisfactory solution for most cities, and it may transpire that even New York has reached the limit of its skyscrapers and multiple-level streets.

Remedies Applied.-But traffic congestion is not confined to the great cities. The City of Memphis, Tennessee, a city with a population slightly in excess of 160,000 in 1920 , is suffering from an inadequate street system, due to lack of system, unsatisfactory crosstown routes, inadequate widths on strategic thoroughfares and jogs and dead ends on what should be "through" streets. Therefore, the most important remedy for the traffic congestion of Memphis is the building of a major street plan for the connection, straightening and widening of existing streets into radial arterial thoroughfares and crosstown routes. In the specific recommendations sharp curves and acute angles are ironed out so far as possible.

The situation in Memphis is not unique. It is typical.

The city of Pittsburgh was suffering from traffic congestion in I910 when Frederick Law Olmsted, Jr., reported to the Civic Commission on the "Main Thoroughfares and the Down Town District." In I92I when the population had increased by more than 50,000 , the Citizens Committee on the City Plan of Pittsburgh published a report on "A Major Street Plan for Pittsburgh." The recommendations involve "widening or otherwise increasing the traffic capacity of 108 miles of existing streets, and the creation of 22 miles of new streets." The program is to be executed during the coming years. The proposals to develop the system of main thoroughfares are designed to secure:

"(I) More direct, definite and ample routes between residential districts and business or industrial districts:

(2) Similar routes between business or industrial districts;

(3) Routes between residential districts;

(4) Continuous cross-town arteries;

(5) Routes through which traffic may be 'by-passed' around the downtown business district (The Triangle)." 


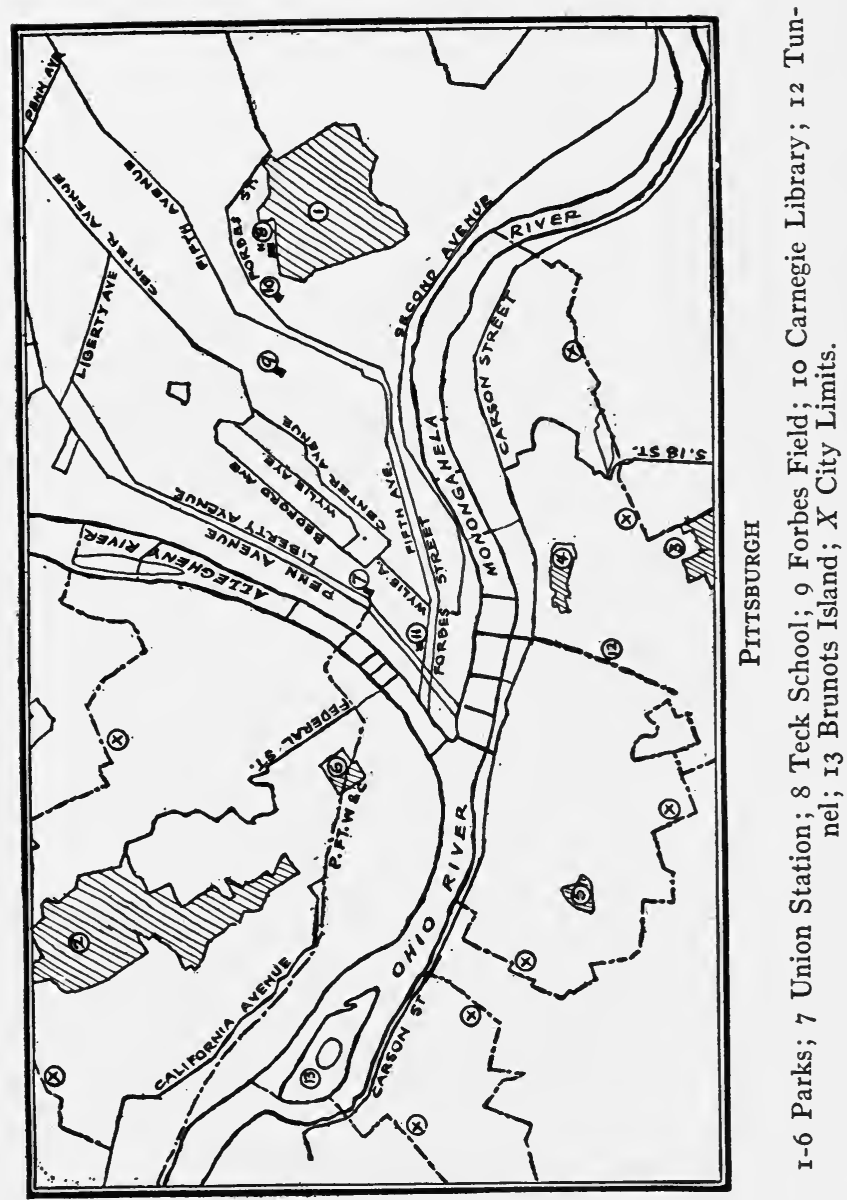




\section{48 LAND PLANNING IN THE UNITED STATES}

The expected economic and social effect of such a plan is especially noteworthy.

"An especial point in the minds of the Committee has been that of making the major street plan flexible,-that is, making possible a maximum choice of routes and communication without useless duplication of thoroughfares. When this is done, the Committee believes that transportation problems may be more readily and satísfactorily solved; that employees, working downtown or in any business or industrial district, will eventually have an approximately equal choice of the district in which they wish to live. This in turn will be of very great importance to employers in their problem of retaining working forces regardless of the part of the city in which the employees live."

The traffic surveys for Pittsburgh were similar in method to those of New York. The graphic presentation shows the concentration of traffic in a comparatively small business district. The proposed major street system would weed out all traffic from the Triangle which was not bound specifically to that destination.

The City of Chicago has embarked on a tremendous program of street widenings, street openings, new bridges and street improvements. Through this comprehensive program "Chicago is emerging from a congestion that resulted from city planning on what Charles $\mathrm{H}$. Wacker, chairman of th Chicago Plan Commission, calls a horse-and-buggy basis. Nar . row streets sufficed in Chicago's earlier days, before the advent of the automobile. The 'loop,' with its nineteen thoroughfares and fifty-seven intersections, is built up to only within 50 per cent of its capacity. In a comparatively short time, as scores of large structures rise skyward, the central business district, with its crawling traffic, would be jammed almost to a standstill were it not for the widening of Michigan Avenue and the boulevard link bridge-the first completed section of the quadrangle of wide streets around the loop."

In r923 Chicago issued 263,329 vehicle licenses. It is estimated that every day there are perhaps 100,000 more vehicles passing in or through Chicago. 
The Chicago Plan Commission has in course of development ten major street projects of which one (the Michigan Boulevard link bridge and the widening of Michigan Avenue) is

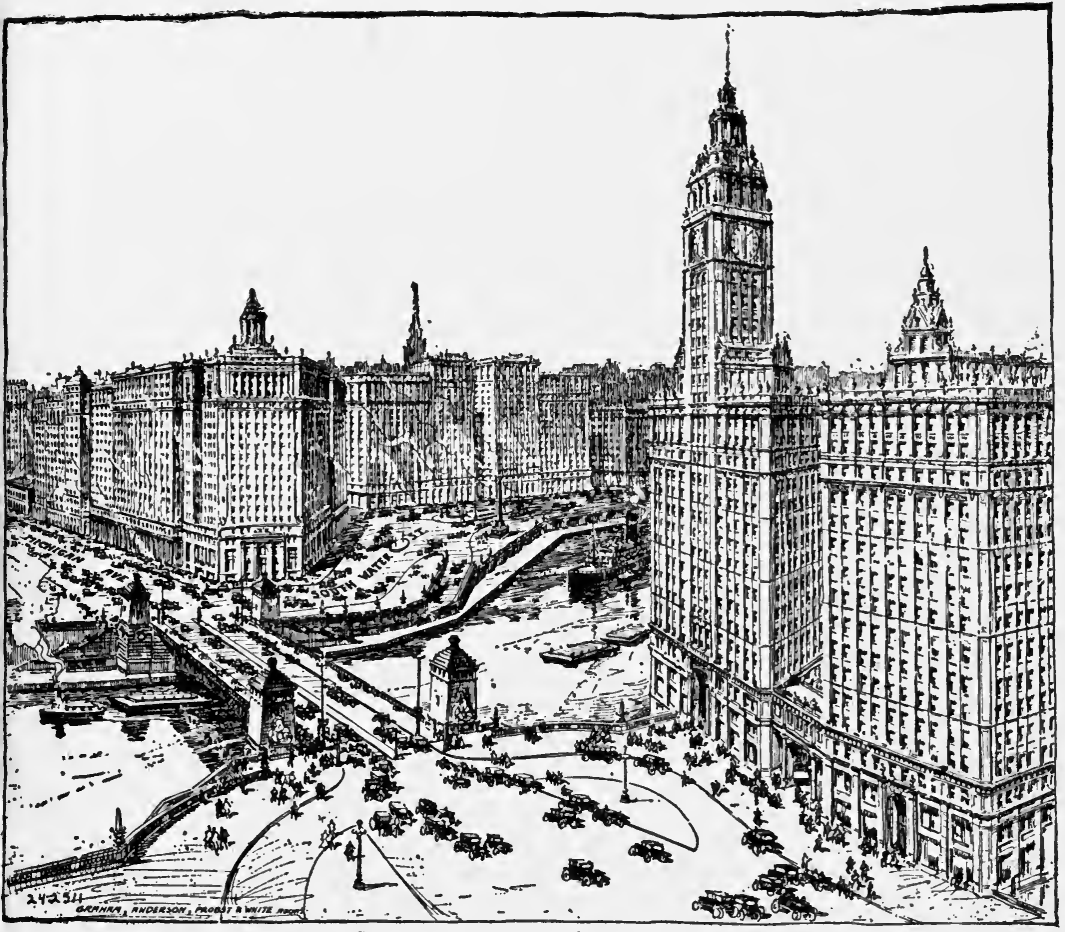

Courtesy of The City Plan Commission, Chicago, Ill.

The Gateway to a Greater Chicago

Intersection of the $\$ 16,000,000$ two-level improvement of Michigan Avenue with the $\$ 20,000,000$ two-level South Water Street improvement along the southern bank of the Chicago River.

completed. It is estimated that the other nine will cost very nearly $\$ 95,000,000$. The produce market is to be moved bodily in the effort to relieve traffic congestion. It will be observed that street congestion is relieved not only by widening and 


\section{I50 LAND PLANNING IN THE UNITED STATES}

extending streets, by re-routing traffic and other regulatory measures; it is definitely relieved by re-locating markets, and directing the location of new wholesale areas and industrial districts. No street system can be considered apart from the various districts of the city.

In Philadelphia there were in 1924 190,000 automobiles owned by the residents of the city in addition to a very large number brought into the city every day from near-by and distant places. In the 130 square miles of area within the city limits there are 1486 miles of streets. Philadelphia has invested in the spacious parkway running from the City Hall to the east drive of the Schuylkill river and has established several other diagonal thoroughfares. A method is now being sought to relieve the traffic congestion on the major northand-south streets by widening and improving alternate northand-south streets. It is claimed that Philadelphia has led in the regulation of traffic in order to make the most of existing streets. It is said that the use of semaphores, the abolition of left-hand turns at certain congested corners, the establishment of no-parking areas and the designation of one-way streets all originated in Philadelphia. Of course lanes and alleys which were wide enough to accommodate only one cart at a time have long been one-way passages; but the one-way use of a street wide enough to carry two-way traffic is a comparatively recent innovation.

The first plan of Detroit, drawn in 1807 , contemplated streets 200 feet, $\mathrm{I} 20$ feet and 60 feet wide. To-day $\mathrm{r} 20$ feet is set as the width for important thoroughfares and 204 feet for super-highways. Within the 85 square miles of the city there were on September I, I924, 221,312 licensed passenger cars and 21 ,oro motor trucks, an average of more than $285^{\circ}$ motor vehicles to the square mile. Detroit has used regulation as a first-aid remedy for congestion in traffic. The six thoroughfares which converge to the half-mile circle of the downtown business district have brought into this small area an enormous traffic. The first remedy tried was the limiting of 



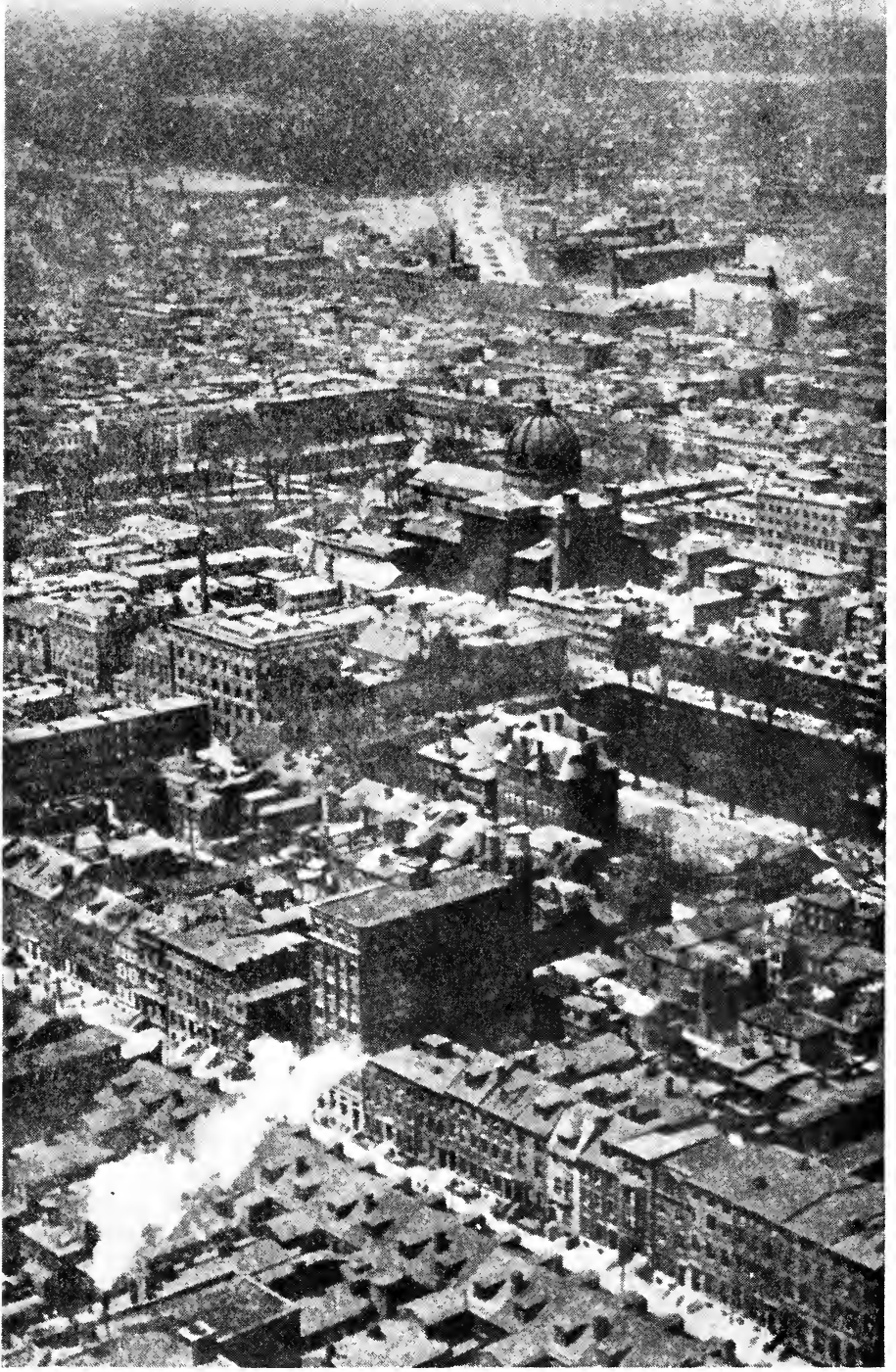

Photograph by Philip B. Wallace, Philadelphia, Pa.

Route of the Fairmount Parkway, Philadelphia, in 1907. 




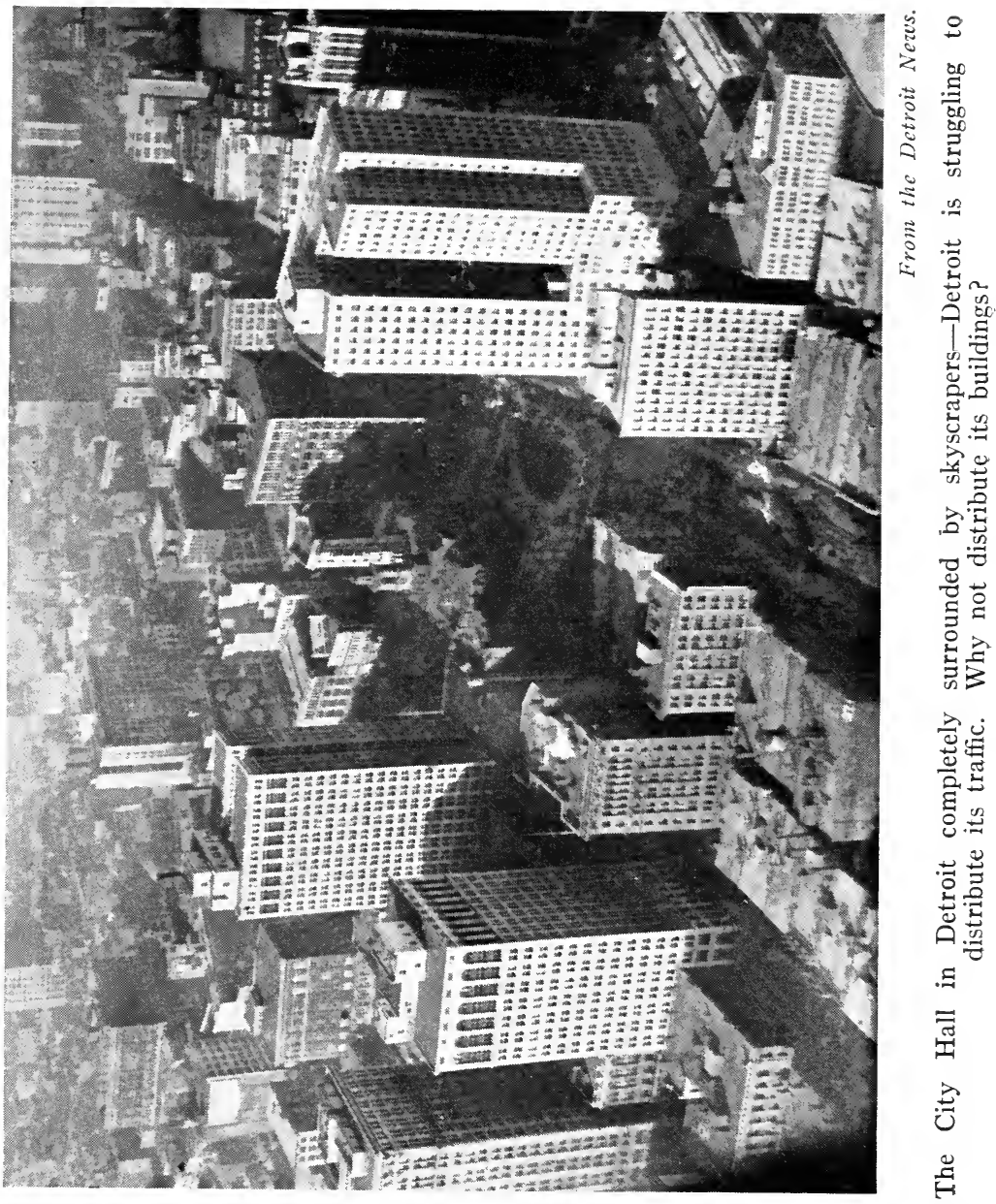


parking for definite times on certain streets; then parking was eliminated altogether on one side of certain streets and in some cases on both sides. Then parking was prohibited on through traffic or "stop" streets during the late afternoon and evening hours. On all streets in the business district and on certain radiating thoroughfares no parking is permitted between $4: 30$ and 6:15 P. M. One interesting effort to distribute the traffic more evenly has been by means of maps prepared by the City Planning Commission which show the "location of car tracks, street and pavement widths and density of traffic. Routes have been so planned upon this map that traffic which does not wish to come into the central business district may by-pass it. This plan will be placed in the hands of traffic directors at factories, trucking companies, and others, in order that the drivers may familiarize themselves with the best routes of travel around the business center." This is an excellent method of promoting the best use of existing streets.

Detroit is following the example of many other cities in making narrower sidewalks and eliminating grass strips to provide wider street way for vehicular traffic. The character of the future development of the property bordering on such streets will determine whether or not the proper width of sidewalk has been provided for the pedestrian traffic, and one cannot help wondering if a proper balance between streets and property occupation may not permit grass strips to be restored in that day when city dwellers come to value access to the face of the earth in whatever oases can be rescued from the desert of concrete and asphalt.

The traffic situation in Saint Louis has been responsible for an extensive street-widening program. In I9I6 there were I 6,000 registered motor vehicles. In 1923 these had increased to more than 100,000 . It is predicted that there will be 200,000 by 1928 . The major street plan of 1917 included the construction of wide, direct and continuous thoroughfares, serving all parts of the city, supplemented by crosstown thoroughfares spaced approximately one-half mile or less apart. 


\section{I52 LAND PLANNING IN THE UNITED STATES}

Existing streets were used so far as possible and the system was designed to be built up by widenings and extensions. Work has progressed on this program, and the bond issue of something over eleven million dollars voted in 1923 will insure the completion of the program. Two-thirds of the cost of these improvements will be assessed against property owners for benefit.

But when it comes to the use of automobiles for twelve months in the year Los Angeles has probably the greatest traffic problem in proportion to the population of any American city. There were 430,000 cars in Los Angeles in 1923that is, one automobile for each 2.9 persons. Relief measures adopted by the city include the "boulevard stop" for five principal thoroughfares, electric flash signals, limitation of parking and prohibition of parking at certain hours and in certain districts. A new school crossing ordinance has been put into effect. This limits the speed to fifteen miles per hour when children are entering or leaving and requires motorists to "stop and wait" at crosswalks marked with yellow paint "when there are pedestrians in the crosswalk on the right half of the road way."

But perhaps the most fundamental contribution to the solution of the Los Angeles traffic situation is the major street plan which was completed and presented to the city July 26,1924 . This plan was the work of Harland Bartholomew, Frederick Law Olmsted and Charles H. Cheney. Los Angeles has been in very great need of continuous, direct connections from one part of the city to another and has been possessed of an unusually large number of dead-end streets which offered absolutely no outlet beyond the residence section which they served.

Freight Carriers in Streets.-The space occupied in our public streets for the carriage of goods is larger than is generally supposed. A recent survey in the downtown district of a large city disclosed the rather surprising fact that onehalf of the total automobile traffic was made up of commercial 
vehicles and that the proportion held fairly constant during the non-rush hours.

The cross streets of lower New York are filled with huge trucks, moving and parked at right angles to the curb during loading and unloading. Any moving vehicle, carrying passengers or freight, even on the one-way streets, must twist and turn around these standing drays and vans as they project into the roadway. Trucks are becoming so vast in size that there is talk of legislation to limit their width, height and length. During the summer of 1924 in many states, automobile counts were taken at various strategic points. On the main highway leading north from Portland, Maine, the make, size and type of every automobile was recorded. The number of passengers was noted and whether they were on business or pleasure bent. The actual width of every car was measured. Such a census should disclose interesting information. The facts on which intelligent control should be based change so rapidly that the old-fashioned rule of general observation is no longer dependable.

In so far as heavy traffic may be classified and separated from the light traffic the street system will profit. Heavy pavements can be provided for trucks and lighter, smoother pavements for passenger automobiles. The South Water Street improvement in Chicago will put the heavy traffic on a lower level with the light traffic above, but the river frontage has made possible such a two-level street. In most sections the separation of traffic must be accomplished through classification of streets.

The Automobile and the Suburbs.-Considering the automobile influence upon street systems and upon city building generally, Mr. John Ihlder has advanced some extremely interesting predictions. Summarizing the influence of various means of rapid transit in the past he suggests that "as it made the suburbs more accessible from the center of town, so it made the center of town more accessible from the suburbs and what had once been distant communication." Concerning 


\section{I54 LAND PLANNING IN THE UNITED STATES}

the tendency to widen roadbeds by setting back abutting buildings or narrowing the sidewalks, he condemns as palliatives any piece-meal widenings and remarks that "any practicable increase of street or road width is immediately filled with more automobiles and the status quo ante is restored." Thus he believes by reason of the fact that the automobile "demands a good deal of space for itself" that "it is forcing us to diminish the density of the population." He calls attention to the disadvantages of streets so broad that they become a menace to the safety of pedestrians who must cross them and suggests that there are better methods of bringing about a proper balance between the street space and the occupation of the abutting property, either by more streets, if needed, or more effectively, through zoning which will regulate the bulk of buildings.

Probably the best summary of the remedies for traffic congestion in city streets is to be found in the recent reports of the various committees of the National Conference on Street and Highway Safety called by the Secretary of Commerce in Washington. The remedies proposed include the elimination of grade crossings, the classifying of traffic, the adjustment of traffic arteries to serve the actual needs of transportation of passengers and freight from the places they would normally start to their destinations; and the creation of by-pass and belt highways to route through traffic around congested districts.

But the most important recommendation was that emphasizing the need for a comprehensive traffic and thoroughfare plan, with proper design and equipment for streets. This, considered in connection with the recommendation for the development of sub-centers or satellites which will promote decentralization of population and distribute shopping and marketing areas, offers a concrete program of much promise. 


\section{SUGGESTED READING}

ERnest P. Goodrich assisted by Harold M. Lewis, "The Highway Traffic Problem," Report presented at Conference on Traffic Problems, called by the Committee on the Regional Plan of New York and Its Environs, May, I924.

John Ihlder, "The Automobile and Community Planning." Annals of the American Academy of Political and Social Science, November, I924, p. I99.

Frederick Law Olmsted, "Pittsburgh, Main Thoroughfares and the Down-Town District." A Report to the Pittsburgh Civic Commission. Adopted December, I9I0, pub. February, IgII.

"A Major Street Plan for Pittsburgh." Citizens Committee on City Plan of Pittsburgh, September, I92 I.

Chicago Commerce, published weekly by the Chicago Association of Commerce. June $\mathrm{r}_{4}, \mathrm{I}_{924}$.

Charles H. Wacker, "South Water Street," Statement to the Chicago Plan Commission before the Finance Committee. May 6, 1924.

J. Borton Weeks, President Keystone Automobile Club, "Philadelphia's Traffic Problems and Their Solution," The Annals of the American Academy of Political and Social Science, an issue devoted to "The Automobile, Its Province and Problems," November, 1924, vol. CXVI, No. 205, p. 235.

T. Glenn Phillips, Consultant, City Plan Commission, Detroit. "The Traffic Problems in Detroit and How They Are Met," in The Annals of the American Academy of Political and Social Science, p. 24I.

Harland Bartholomew, "Reduction of Street Traffic Congestion by Proper Street Design, How St. Louis Is Meeting Its Problem," in The Annals of the American Academy of Political and Social Science, p. 244 .

Paul C: Hofrman, "The Traffic Commission of Los Angeles, Its Work on the Traffic Problem," in The Annals of the American Academy of Political and Social Science, p. 246.

Stanley Pinel, Asst. Municipal Engineer, Engineering Extension Department, Iowa State College, Ames, Iowa. "Curb Radii and Safety," in Special Bulletin of the Iowa Town Planning Association, No. 13, March, I923.

Proceedings of the National Conference on Street and Highway Safety held December I5 and I6, I924. Committee: Herbert Hoover, Chairman; F. A. Delano, Vice-Chairman; A. B. Barber, Director; Ernest Greenwood, Secretary. 


\section{I56 LAND PLANNING IN THE UNITED STATES}

\section{NOTES}

Page 138:

In May of 1924 the Committee on the Regional Plan of New York and its Environs called a Conference on Traffic Problems at the Town Hall. At this conference Mr. Ernest O. Goodrich, assisted by Mr. Harold M. Lewis, presented a report on "The Highway Traffic Problem." In this réport the problem is divided into three divisions:

"I. Traffic.-Movement of persons or goods upon highways by free-wheel vehicles, or by vehicles using tracks laid in the highways.

"2. Transit.-Movement of persons and of mail, baggage and express matter, within or between the different cities or other municipal units included in the territory, by ferries or other water routes; by railroads in subways or tunnels, upon elevated structures, or upon separate rights of way, but not upon public highways; or by some form of air draft.

"3. Transportation.-Movement through the Port of New York, or to, from or between different points outside the port district, but within the territory under study, of freight of all kinds by railroad, deep sea or coastwise shipping, or by inland waterways, and the handling of passenger traffic by trunk line railroads."

While this report was made upon the specific territory of New York and its environs and confined to the first of the three divisions, the analysis seems applicable to the consideration of the general subject matter.

Page 140: The following table estimating the number of cars per lane which can pass a given point in an hour, while in terms of New York streets, illustrates the dispatch which traffic can be given under typical down-town conditions of different types of streets.

Park Avenue Viaduct across 42 nd St. and

around Grand Central Terminal..... 800 cars per lane per hour

Fifth Avenue-Unobstructed roadway with

traffic regulation..................

Street with no obstructions but elevated

R. R. columns................ 700

Unobstructed 3 lane street............ 700

\begin{tabular}{|c|c|c|c|c|}
\hline 750 & " & " & " & " \\
\hline$\infty$ & " & $"$ & $"$ & $"$ \\
\hline ০০ & " & $"$ & $"$ & $n$ \\
\hline 600 & $"$ & " & " & $"$ \\
\hline 75 & $"$ & $"$ & $"$ & " \\
\hline & $"$ & " & $"$ & " \\
\hline
\end{tabular}

Broadway or 8th Ave., street with four

moving lanes and trolleys...........

Lexington Avenue, street with three mov-

ing lanes and trolleys..............

Sixth Avenue, street with trolleys and ele-

vated R. R. structure............ $400 "$ " "

Page I45. Commenting on overcrowding, Mr. Raymond Unwin declared before the Royal Institute of British Architects in December of 1923, that it was necessary, to understand the traffic aspect of the 
high building question, to realize the extent to which an increase in the height of buildings affects the demand on street space. He has calculated that a building in the loop area of Chicago, standing on a corner with an alleyway in the rear, measuring 160 by 172 feet, would, with five stories, hold 2,or 8 people, and that these people would take up a length of 504 feet of footway if they were standing and a length of 1260 feet if they were walking, and that the length of 1260 feet of footway would, ordinarily, be occupied for five and one half minutes before the occupants of one building could pass away from it. If the building were increased to ten stories, the population would not be doubled, but would be about 3704, and the length of the footway to accommodate them would be 2315 feet. The time required to clear this number would be ten minutes. With an increase to twenty stories, the population would be 6930 , the length of the footway occupied 4330 feet and the time to pass twenty minutes. Mr. Unwin shows that the congestion of motor cars to accommodate even the one tenth of such a population who might be presumed to own cars is equally appalling. If the cars were allowed to fill the whole of the carriage way, they would occupy 2772 feet for a twenty-story building and nearly three quarters of a mile for a thirtystory building. If only half of the carriage way were permitted to be used the distances occupied would double.

A recent report by $\mathrm{Mr}$. Harland Bartholomew on Memphis, Tennessee, lays emphasis on the major street system in relation to traffic.

As is the case in many other cities the earlier streets are more useful to-day than those laid out at a later period.

"The streets of the first original town, now serving the central business district, are the only ones which form a co-ordinated system. This fact is responsible in large measure for the continued ability of these traffic ways of early origin to serve the needs of present-day Memphis. More recently laid out streets are unusually haphazard in arrangement.

"Absence of good crosstown routes likewise prevents proper intercourse between districts. . . . The city has not a single north and south thoroughfare that is both continuous and adequate in width. ... The lack of suitable east and west crosstown streets above and below the business center is equally serious.

"Inadequacies of width further lessen the value of the streets of Memphis. The routes of old roads and trails which in the early days connected the settlement with the surrounding country have fortunately been fairly well preserved. They appear as radiating arteries in the street plan, affording practically direct approach to what is now the heart of the city. Instead of being commodious traffic ways, however, these radial arteries are mostly narrow, with many angles. ... .

"Practically all the faulty streets with which Memphis to-day finds itself provided and trying to grow upon have developed 
through shortsightedness. City officials and citizens generally in the past have failed notably to appreciate the city's opportunities for future growth. Those who have laid out land subdivisions have been particularly negligent in considering the interests of the community at large. Immediate returns from the sale of the land was the main consideration, and the city had no guiding plan which might be followed even if a land subdivider did evince an interest in the larger community. Land has been subdivided according to the owner's ideas, and streets as opened, whether wide or narrow, continuous or broken, have been forced to serve any and all purposes. The consequences of this haphazard, irresponsible method of building up the street system are seen in:

“(I) Unsymmetrical city growth.

(2) Abnormal property values.

(3) Improper street car routings.

(4) Congestion.

(5) Retarded traffic movement.

(6) Accidents.

(7) Abuse of pavements."

Page 140: Mr. Bibbins comments on these systems of traffic control:

"There is much to be gained by the study of the variable versus the fixed signal system. For some reason, almost all of the block signal systems that have been installed have been placed on an arbitrary fixed period basis running through the day (9 a.m. to 9 p.m.) regardless of the traffic, the weather, the day of the week or the season, and particularly of the varying amount of cross traffic. The result is needless to observe, in cases of this kind, that a large proportion of the signals are held open after all the traffic has passed (i.e., with an idle crossing), waiting for the clock to tick for the next signal change. This is most unscientific. Street car schedules cannot contain so much lost motion. Why should traffic?"

In a paper read before the Senate Committee on Traffic Inquiry in the District of Columbia, Mr. J. Rowland Bibbins discussed traffic remedies.

"Divers traffic remedies have been proposed. The list is a long one, the range of opinion extreme, thus: from simple painted traffic lanes to ruthless street widening; from 'limited' parking to 'no parking'; from the policeman's 'long arm' to the huge block signal towers; from simple white line safety stations to the monumental concrete loading stations in the street; from few traffic officers to hundreds; from simple boulevard stops to thank-you-ma'ams around each crossing; from all two-way streets to all one-way streets reversed morning and evening; from the policy of no obstructions whatever in the streets to the 'death-posts' of recent experience; from a time signal actually needed by the traffic; and from no cars in the down-town section to no autos within the same district except on the move. ...

"There seems to be a good deal of misunderstanding about the 
function of one-way streets. This method was originally designed to increase the capacity of narrow roadways where the width was not right for an even number-2, 4, 6,-two-way traffic lanes. In such cases, one-way operation brought more effective use of the given roadway by securing an extra lane or odd number-3, 5,in the desired directions. One-way operation was not originally intended to be applicable to wide streets suited to the requisite number of traffic lanes in two directions. Especially is this the case where the distribution of traffic streets is uneven making necessary long detours to move in the desired direction. One-way streets likewise tend to concentrate movement in the morning at one series of points and then in the evening at another, instead of distributing traffic at all times. The system is clearly a makeshift-not a cure, and must be applied with extra precaution or the congestion it sought to avoid will simply be transferred to another point." Nov. 19, 1923.

Page 14I: The discussion of the parking problem in the report on the Highway Traffic Problem in New York and its Environs is illuminating and shows the trend of thought of the Engineers.

"Streets and Roads were originally designed for movement of vehicles. Except in rare instances they were toll roads in the outlying districts. The standing of conveyances upon the highways was often explicitly prohibited. In Elizabethan times, when Hackney coaches were first introduced into London, an ordinance was passed requiring them to stand within enclosures on private property, much in the same manner in which taxicab stands are often provided by the Corporations which operate them. Fundamentally, it is probably illegal to occupy street space by parked vehicles even for loading or unloading purposes. It seems, however, an unnecessary hardship to preclude the parking of an owner's car in front of his premises on a little used residence street where no hardship would be involved upon neighbors or traveling public. It is obviously a public hardship, however, to permit the use of sometimes as much as two-thirds of a street by standing vehicles which remain for hours while the owner occupies himself in his office or in other ways.

"With the great increase in the use of automobiles their parking has become an acute problem. At many points in almost every community, however large or small, present facilities are taxed to their full capacity and ordinances are being enacted, which become more and more stringent with each passage restricting the parking time and in some cases prohibiting it entirely. Public opinion is of such present temper that it demands all the facilities which seem reasonable, and more. With these facts in mind officials are creating parking spaces on open plazas, along the sides of less used streets, and on publicly owned properties. Pressure in some cases is so great that communities have purchased properties for this specific purpose. This practice is open to grave question as to the reasonableness of the use of public funds for this purpose. Where spaces already exist, which are not otherwise used, it seems reasonable that they should be set aside for parking purposes. In Manhattan it might be possible to set aside in this manner considerable areas 
along water fronts and to encourage vehicle owners to park at such points under police protection, or that of paid concessionaires,owners walking from such parking spaces to their offices, even though the distance might be several blocks in many instances.

"Private enterprise is endeavoring to cope with the situation by providing terminal garages. The well-known Spiral Ramp Garage which has been erected in Boston is an excellent example of one method of solving the problem. Wherever possible, taxicab corporations should be required to provide their own stands on private property and pressure should be brought to bear on all concerns which operate a large number of vehicles which load at central points, to provide loading space wholly within property lines. The passenger unloading spaces at the Pennsylvania and Grand Central Terminals are of this type, as are also the spaces provided by Wanamaker and other stores for loading their delivery wagons off the public street.

"The increasing stringency exercised with reference to parking time points to ultimate conditions when no parking will be permitted on any north and south avenue in Manhattan, the resulting capacity for traffic will be increased to $150 \%$ of the present use and were certain changes to be made in the carrying capacity of some of the avenues by the removal of elevated and trolley tracks, the simple prohibition of parking would make possible the doubling of present use."

Page 154: The Committee on City Planning and Zoning submitted the following recommendations to the National Conference on Street and Highway Safety, December 15-16, 1924:

\section{"SUMMARY OF RECOMMENDATIONS}

"I. Street and highway hazards are due chiefly to vehicular traffic. These hazards can be greatly reduced by a proper arrangement of streets and highways. Consequently each community must necessarily study and carefully consider its own special problems with particular emphasis upon:

(a) The problems presented by streets and highways crossing each other at grade or crossing railroad or rapid transit at grade, with the two purposes of reducing the number of crossings by a better arrangement of transit lines and thoroughfares and by separating grades so far as practicable where crossings remain necessary. Elimination of grade crossings is most needed along major traffic arteries or boulevards.

(b) The problem of classifying traffic and of providing suitable and adequate facilities for each class. This involves the proper location of the various kinds of development; industrial, commercial, residential, through a proper planning of traffic and other public facilities provided in the various areas, supplemented by zoning regulation of private property.

(c) The location of its traffic-originating centers and the possible development of its outlying areas with the two purposes of straightening main traffic arteries and of so spacing them that 
there will lie between them areas sufficient in size to support neighborhood stores, schools and recreation facilities.

(d) The possibilities offered by its topography and its present development to create by-pass highways and belt highways, which will permit through traffic, especially trucks, to avoid congested districts or even any built-up portions of the city or town.

"2. Stopping and Day Storage Space for Automobiles. Each community should reach a decision, based upon present local conditions and probable future development, as to how it will provide for the stopping and parking or day storage of automobiles, and should apply that decision in its city plan.

"3. Design and Equipment of Streets. While the arrangement of streets and parking spaces is the first essential in securing an even and safe flow of traffic, this must be supplemented for each kind of street by determining the most effective width, corner radius, sight clearance, etc., and the needed equipment, such as safety zones or isles of safety, lighting devices, traffic signals, pavement marking. These will differ with the character of the street and the width of its roadway.

"4. Importance of Sub-Centers and Satellites. It is necessary for each region or group of communities to plan more carefully the development of industrial and business and sub-centers, and satellite communities with a view both to encouraging appropriate decentralization and to preventing these new centers from in turn becoming areas of traffic congestion and danger.

"5. Relation between Street Facilities and Development of Private Property-Zoning. Each community should, in determining the character, width and arrangement of its streets, at the same time, determine, through zoning, the character, use and bulk of abutting buildings.

"Each community or group of communities in planning the main arterial highway system should take account of the effect of zoning regulations in regulating and stabilizing traffic flow.

"6. Playgrounds and Schools. Each community should study the opportunities offered by its territory to provide playgrounds and recreation spaces adequate in size and number so that it will not be necessary to use the roadway for play purposes, and, like the schools, so located that children will not have to cross busy traffic streets in going to and from them.

"7. Inter-relation of Trafic Facilities. Each community should, in planning its traffic system, bear in mind that the automobile and the motor bus supplement rather than conflict with rapid transit rail lines.

"8. Comprehensive Trafic and Thoroughfare Plan Necessary. In order that a community may deal effectively with its problems of street and highway safety it must co-ordinate all its efforts in a comprehensive traffic and thoroughfare plan, showing a complete system of traffic ways, parking or automobile storage and needed street improvements both within the city limits and within the area of probable building development outside of the city limits. The traffic and thoroughfare plan should be developed in consonance with a plan for transportation and transit lines and stations with 


\section{I62 LAND PLANNING IN THE UNITED STATES}

zoning regulations. The adoption of these plans should be followed by a definite long-term improvement and financial program."

Page 149: The benefits to be expected from the South Water Street improvement are listed by the Chicago Plan Committee:

"(I) A saving of $\$ 12, \infty 00,000$ per year for the people.

(2) Increased property values north, south and west of the river, and throughout the central district.

(3) Increased city revenue, resulting from increased property values.

(4) The creation of two new streets-an upper and a lower thoroughfare in South Water and River streets-where there is practically none to-day, because the present thoroughfare is entirely absorbed by private business.

(5) Increased traffic facilities on north-and-south and east-andwest streets, through the removal of 16,000 market vehicle trips per day, and the elimination of the present clogging of north-and-south thoroughfares by market vehicles.

(6) The provision of an interrupted heavy-traffic connection on the lower level between the industrial district on the north side; the boat and freight terminals east of Michigan avenue; and the west and south west side warehouse, terminal, and industrial districts.

(7) A 4I per cent reduction in loop traffic, saving time and money for everybody.

(8) The establishment of dock facilities, equipped with tunnel and freight station connections, for marine landing, barge, steamboat, warehouse, and storage purposes, thus making the Chicago river an object of use, beauty, and profit, instead of ugliness and loss. The World's Fair taught us the value of capitalizing the lake front. The South Water street improvement is the first step in capitalizing the river front.

(9) It will aid Chicago to maintain its commercial standing, and successfully to compete with other progressive American cities.

(I0) It will produce the greatest amount of value from the expenditure of $\$ 10,000,000$ (the public money involved) which would have to be spent in that district even if the improvements were not made."

Rather far-reaching results to be expected from a street extension and improvement program! 
CHAPTER IX

\section{TRANSIT AND THE STREET SYSTEM}

Public Conveyances in the Streets.-Of the public conveyances for the transportation of passengers through the streets of our cities the electric car is the most important. The laying of tracks in the streets, the selection of car routes, and the terminal stations have an intimate effect on the width and arrangement of streets. Not only must the requisite space be given over to the tracks and their cars, but loading and unloading space must be provided at all stops. Whether these loading spaces consist of raised concrete platforms or whether they are merely indicated on the pavement by painted stripes, they narrow the street space for traffic into a succession of bottle-necks and diminish the traffic capacity of the street by just so much. But wherever there are street car tracks in the center of congested roadways the safety islands or loading spaces are absolutely essential.

Street car tracks have been laid in many streets which are so narrow that there is not room for a single lane of automobiles between the street car and an automobile or delivery wagon standing at the curb. Since there has been a decided tendency for business to follow the routes of street cars even into residence sections, and since street cars often follow the radial thoroughfares out into the outlying sections, all sorts of traffic compete with the street car and add to the congestion. Ordinarily there should be room on each side of a double line of street cars for two lanes of traffic passing in each direction, one standing and one moving. On many thoroughfares three or four lanes are not too many.

Therefore when there is an adequate radial and crosstown 163 
street system, laid out and developed with broad thoroughfares for the car-line streets, much trouble and expense is saved. Whenever it is necessary to lay tracks on streets inadequate in width, unsuitable in directness and inconvenient in grades, that fact should be sufficient notice that the street system needs study and revision. Of course the very best use of any existing street system for the routing of carlines should be developed in any case, but when the population is sufficiently large

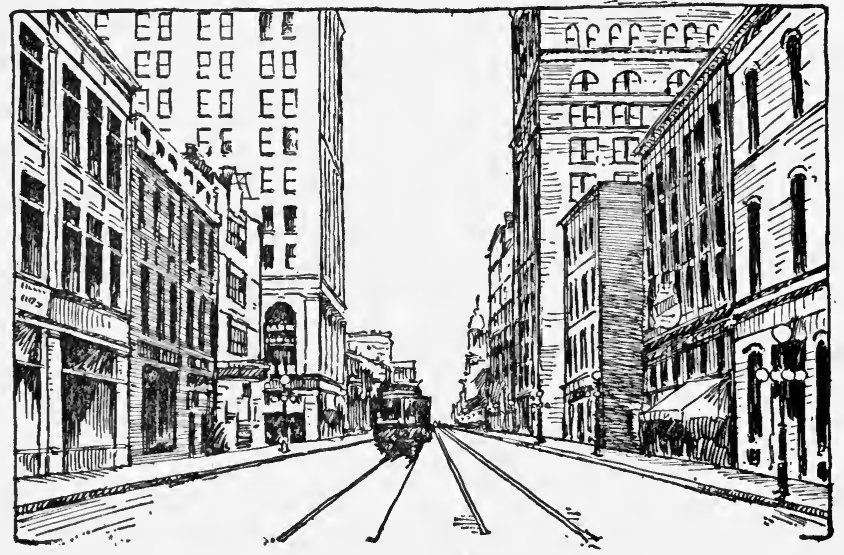

Widening city streets by establishing a setback for new buildings.

to justify the operation of street cars to any particular section that should be an advance signal to study the street connection and make provision for widening, straightening and grading before the land and buildings bordering on the street become too expensive. Streets are frequently widened by the simple practice of enforcing a new setback building line so that no new building can encroach on the proposed wider street. In time there will only be a few old buildings extending to the original street line. During the transition period the street presents a ragged appearance; but any method of street widening is apt to be slow, expensive and disfiguring for a considerable period of time. These are among the penalties for fail- 
ing to lay out adequate streets in advance of their use. If the first opportunity has been neglected and the city has developed to the place where street cars are demanded, that very fact should be taken as a second opportunity for developing proper streets before the difficulties increase.

In the frontispiece of the Pittsburgh Report of the Civic Commission in r 910 it was shown that of the 530 miles of main thoroughfare within a radius of seven miles of the City Hall, less than one and one-half per cent have room for passage between cars and vehicles, slow-moving or standing at the curb. It is not remarkable that the need for a better street system in the down-town district was recognized at least fifteen years ago.

There are those who believe that the street cars running on tracks will be entirely replaced during the next quarter of a century by free wheel vehicles. The rapid development of the de luxe busses in which tourists may be shown the sights of American cities and the growing use of interurban automobiles and busses make this seem within the bounds of possibility.

The Fifth Avenue busses in New York were an institution in the old days when they were horse-drawn. To-day they render an important public service. On Fifth Avenue there are no car tracks and the busses, of course, load and discharge passengers at the curb.

Already the omnibus has supplemented and sometimes displaced the street car running on tracks. In many instances the latest models are quite as wide and often as long as a standard street car. If such large free-wheel vehicles come into general use it will be necessary to revise our estimates for the unit width of lanes of traffic. It may be imperative to require such large vehicles to operate in lanes keeping near the sidewalk, thus allowing the smaller, and presumably, faster, vehicles to occupy the space nearer the center of the street.

But whether the public conveyances are cars operated on the surface or on elevated or subway tracks or by free-wheel vehicles, it is clear that no large city can be served adequately 


\section{I66 LAND PLANNING IN THE UNITED STATES}

if the routes of these various methods of transportation are not considered as a unit and planned to supplement each other. In a recent report setting forth the "Outstanding facts and salient provisions of an Ordinance providing for a comprehensive municipal local transportation system," it is claimed that the proposed ordinance "provides for a comprehensive unified system embracing surface lines, elevated lines, subways, busses and any other means of local transportation which may now or hereafter be considered desirable."

One of the disadvantages of the system which permitted municipalities to grant franchises to different companies for different types of local transportation was that the routes, even when controlled to some extent by public utility commissions, did not form a complete system to serve the community.

The Chicago Plan includes the "re-routing of the surface lines so as to make them really short-haul lines serving as feeders of a comprehensive rapid transit system composed of subways and elevated lines."

It is certainly poor business for a municipality to grant a franchise to a surface street car company to carry passengers in cars run on tracks laid in the public streets of the city and then to grant a franchise to a competing omnibus company to carry passengers on free-wheel vehicles over exactly the same route or one which will parallel it to the extent of draining patronage from the street car company. And yet there are scores, if not hundreds of cities in the United States to-day where the tax payers are suffering from exactly this sort of poor management, frequently involving financial disaster as well as poor service to the public.

The routing of free-wheel busses may be changed from time to time more readily than that of street cars operating on tracks laid by permission of long-term franchises; but the size of many of the modern busses makes it desirable, if not imperative, that they run on streets which are wide enough to carry such large conveyances without blocking the general vehicular traffic every time they stop for passengers. 
The lesson which City Planning has to teach is that the routing of all local transportation should be planned as a unit, with possible extensions sketched out in advance to meet the growing needs of increasing population. No matter how large a city may grow and no matter how decentralized some parts of it may become, there are common centers which should be placed in communication with all outlying sections. Whether the busses are used as feeders and supplementary to the street railways, or whether they supersede the electric lines, the system should be planned as a whole.

Rapid Transit.-In the larger cities rapid transit by means of subways, elevated railways and ferries becomes a problem which seems to become difficult at a greater rate than the actual growth in the population. Mr. Bibbins refers to the "paradox of transit traffic increasing as the square of the population" in New York City. He believes that in most cities transit traffic increases in geometric rather than arithmetical progression as compared with increases in the population.

The relative advantages of elevated and subway structures to provide safe and rapid transit from the suburbs to the crowded metropolitan centers depends on the topography and many other conditions. Elevated roads may be highly preferable in the open country or along open highways where there is a sufficiently wide right of way to permit a high embankment, with sodded slopes or solid retaining walls. In crowded city streets, the elevated roads, though they remove much traffic from the surface and offer dispatch, have the offsetting disadvantage of decreasing the light and air and increasing the noise so that they are a positive nuisance to the dwellers or workers in the buildings along the line.

The subways have exactly the opposite advantages and disadvantages. They are quiet. They do not affect the light and air of the buildings. But the passengers do not fare as well in the underground tubes, except where the right of way is on a wide street or other location unoccupied above which will permit light and air to penetrate to the trains. 
Like so many other problems of city planning the decision as to when the time has arrived when elevated or subway transit is needed depends upon many considerations. If the time to make the change is when the traffic has become so great that the immediate patronage will bring returns on the money invested, the physical conditions are usually such that installation is extremely expensive. It was estimated by Mr. Daniel L. Turner, Consulting Engineer of the New York Transit Commission that the cost per mile of single track in underground trolley railroad in congested streets, including pavements, conduits and care of subsurface structures under conditions such as those in Washington, D. C., would amount to $\$ 48,500$, while the same construction under conditions existing in New York would amount to $\$ 126,500$, quite a substantial difference. Mr. Lewis, writing in 1922 , stated that the costs of labor and material at that date would make it necessary to add $50 \%$.

If, on the other hand, subways or elevated railways are erected in order to open up new areas for residences and bring them into rapid transit communication with the down-town sections, the construction of such roads may be justified as an advantage to the business community and it may be good policy for the citizens to contribute to the cost of construction as was done in the extensions to the transit system of New York. But in either case the task is cheaper and the transit lines can be built to yield a better service if the street system has broad arteries which reach out into the surrounding country. It is true that in lower New York the transit lines occasionally pass under buildings and leave the route of the streets; but the broad street which will permit the construction of elevated or subway lines without undue encroachment on the use of the surface by vehicular traffic is an advantage to be greatly prized. The street system of any growing city should contain within it thoroughfares which could some day accommodate rapid transit lines.

New York and San Francisco provide part of their rapid 


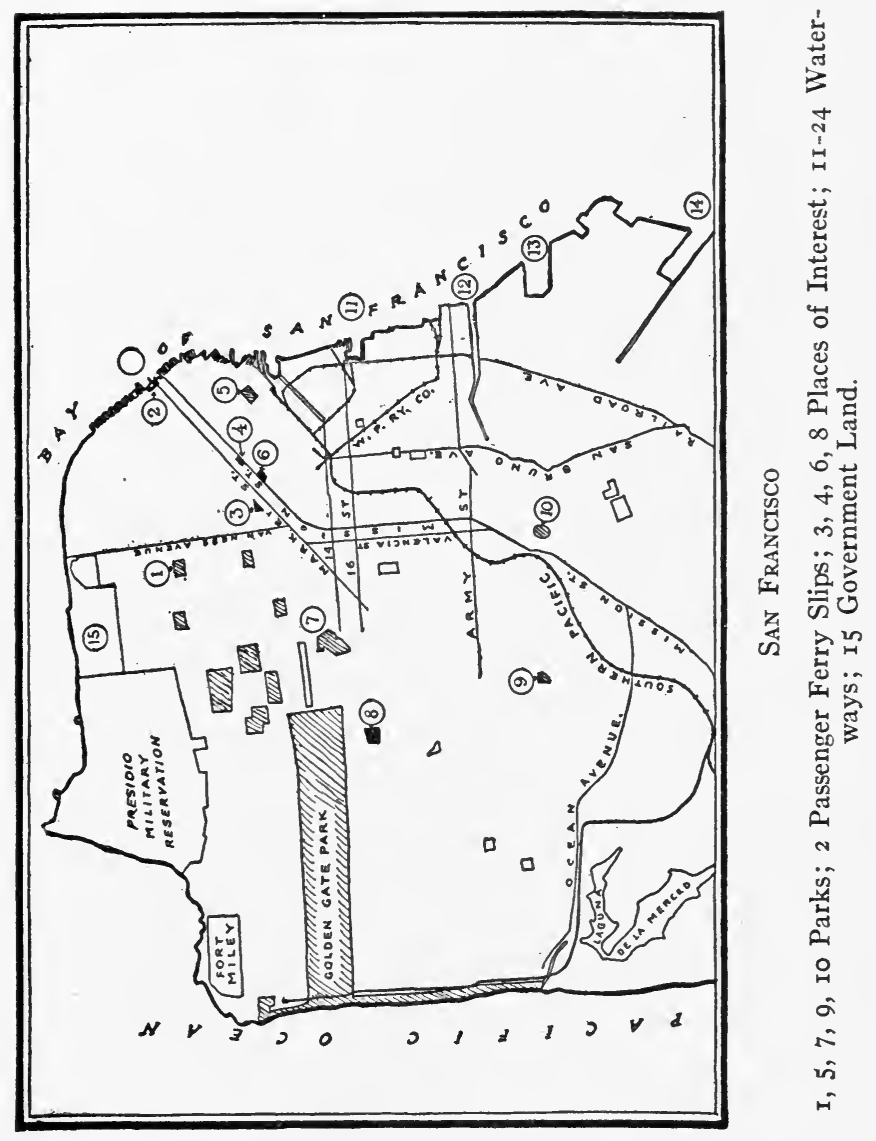


transit connection with surrounding areas by ferry. Before the first Pennsylvania tunnel was built passengers on all trains

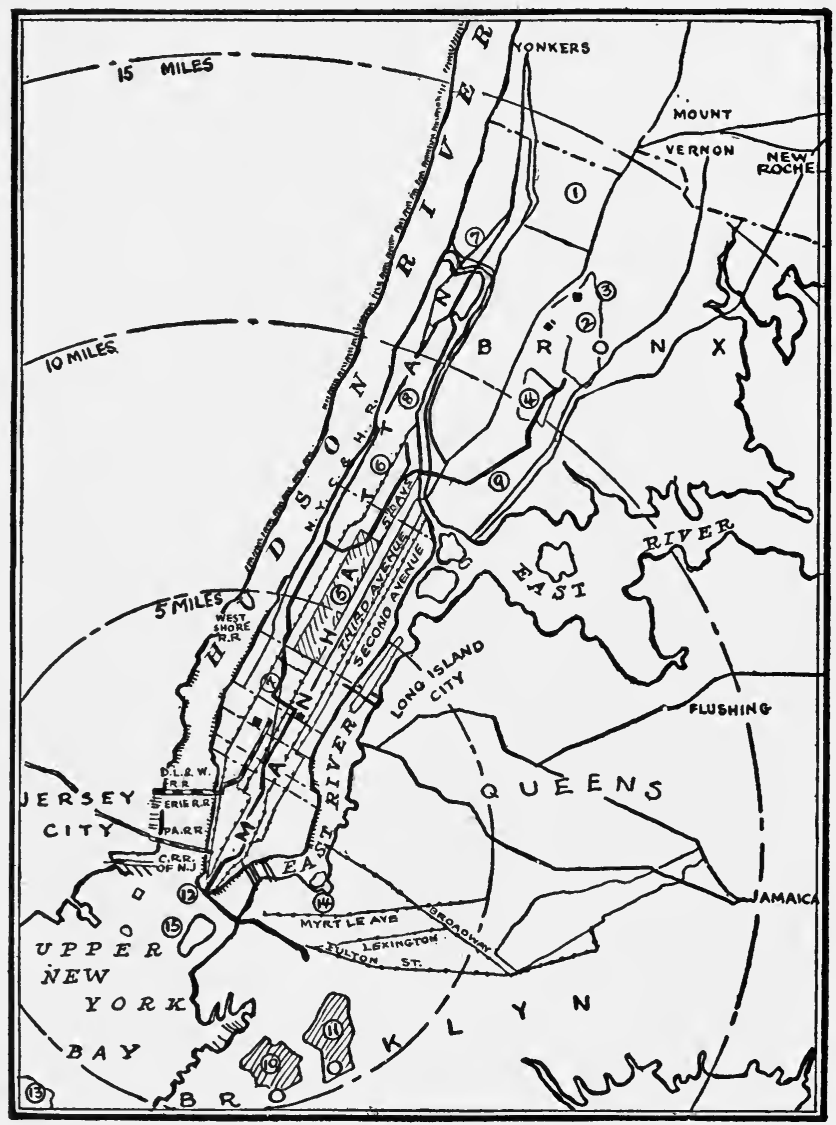

New York City

I-4, 6-9, II, I2 Parks; 5 Central Park; Io Greenwood Cemetery; I3 Richmond; I4 U. S. Navy Yard; I5 Governor's Island.

from the south were ferried into New York. There are those who prefer the ferries to the tunnel even now. For many years all transcontinental travelers were brought into San 
Francisco by ferry. Now that the "gap" in the Southern Pacific Coast route is closed, trains from the south bring through passengers into the railway station by way of the neck of the peninsula. But San Francisco Bay has not been bridged or tunneled. The Central Pacific west-bound trains exchange passengers at the Oakland Mole to ferries which ply between there and the foot of Market Street, San Francisco. There are ferries from San Francisco to Oakland, Berkeley, Alameda to the east and to many of the towns to the north of the Golden Gate.

Not only is there a heavy passenger traffic on all the ferries which cross the Hudson River and on the ferries of San Francisco Bay, but there is an increasing automobile traffic on all boats which have facilities for carrying cars. The wharves for accommodating ferry traffic, afoot and awheel, form a very important part of a city plan. The ferries of former years have in many instances been superseded by bridges and tunnels. The new bridge across the Hudson leading to Bear Mountain will provide an important automobile outlet which will compete with near-by ferries. When an automobile tunnel connects Manhattan with New Jersey there should be an enormous use of such a route, particularly if the feeding highways in New Jersey are smoothly paved. Whether this would decrease automobile traffic on the ferries remains to be seen. In New York it has frequently happened that new facilities for traffic have been eagerly used without in the least decreasing the patronage on existing systems.

Both in New York and San Francisco there is a heavy freight traffic by way of the ferries. A great deal of it is by way of automobile trucks which are themselves transported, thus saving loading and unloading.

\section{SUGGESTED READING}

J. Rowland Bibbins, "How Shall We Solve Traffic Problems?" Reprint from Electric Railway Journal, February 23, 1924.

J. Rowland BibBins, "Hauling Ford Workers," in Electric Railway Journal, September $15,1923$. 


\section{I72 LAND PLANNING IN THE UNITED STATES}

Francts X. Busch, "Outstanding Features and Salient Provisions of an Ordinance Providing for a Comprehensive Municipal Local Transportation System." A recommendation to the City Council by the Committee on Local Transportation, February II, 1925, Chicago. George Duncan Snyder, "City Passenger Transportation in the United States." Minutes Proceedings of the Institution of Civil Engineers, vol. CXCIII.

Nelson P. Lewis, The Planning of the Modern City, Chapter V, The Transportation System.

\section{NOTES}

Page 163: Mr. J. Rowland Bibbins, writing in the Electric Railway Journal, makes reference to the recent survey under the auspices of the City Plan Commission of Indianapolis.

"Zoning," he says, "is an accomplished fact in this city. The commission next turns to the transportation plan, broadly conceived, the first step of which is the development of a city-wide, comprehensive traffic throughfare system. These thoroughfares are being classified and designed for auto speedways, boulevards, local and rapid transit streets and heavy traffic streets, with particular reference to the by-passing of traffic foreign to the central business district.

"The next step will be to develop traffic organization and control involving the usual multitude of details, particularly to afford relief to the central district.

"The third step will seek improved rail routing and operation, particularly in the congested district, but also as affects the entire transit system. ...

"The fourth step involves railroad terminals, line and grade separations, as all these factors involve city development, continuity of main thoroughfares and the relief of traffic and transit obstruction."

Page 163: Mr. Nelson P. Lewis discussed the question of near and far-side stops in his book.

"The varying custom in different cities, and even in the same city, as to the side of the cross street at which surface cars and omnibuses shall stop to take on and discharge passengers has been the cause of much confusion and delay and of not a few accidents. The farside stop has been the general rule, except where the cross street is also occupied by a railroad, when the cars stop at the near side, or frequently on both sides. Many cities have adopted stringent rules as to the stopping place for surface cars and omnibuses, and have painted on the surface of the pavement the spaces within which passengers may stand and upon which vehicles may not encroach. New York has lately adopted the near-side stop for all crossings, and the records of the Public Service Commission show that for the first three months during which the new regulation was in force there was a decrease of II 85 accidents from the number during the corresponding three months of the preceding year, although during the 
first month there was an increase of 158 in the number of accidents to those boarding cars, owing to the fact that, not being accustomed to the new rule, they waited at the far side and then attempted to board moving cars."

Page 165: A most interesting comparison of service, time and cost between street cars and "jitneys" is presented in the accommodations for the workers at the Ford plant near Detroit.

"The great bulk of those who need transportation to and from the works use the street cars. . . . This movement has reached about the maximum possible under present loading conditions, i.e., a two-car train every sixty seconds with practically full car loading. Passengers board the cars at present in the street or on the loops in the Detroit municipal car yards, in queues, and the loading speed averages one second or more per passenger boarding. It will be noted that this movement of factory employees is in the contrary direction to the normal city-rush hour traffic, morning and evening. . . .

"In addition to street cars there is on Woodward Avenue a loop or jitney service. These jitneys are large eight-passenger automobiles which, during the rush hour, operate on a headway of about onehalf that of the street car trains. The fare on these motor cars to down-town Detroit is from two to three times the fare on the trolley cars, and the speed is nearly twice that of the latter. This service was encouraged by the city when the railway was operated by a private company, and the jitneys are now in litigation to retain their licenses in competition with the municipal railway.

"The third transportation service is given by private automobiles. ... In a count made on June 28 , I923, between 3:10 p.m., and 4:30 p.m., I 200 automobiles per hour were found to be moving south on Woodward Avenue past the corner of Manchester Avenue, 9I 5 moving north on Woodward Avenue, 226 moving east and 169 west on Manchester Avenue in addition to 10,920 pedestrians homeward bound through this street, mostly crossing at Woodward Avenue.

"The greatest congestion occurs at the corner where Manchester Avenue enters but does not cross Woodward Avenue. At this ' $T$ ' street junction there is a traffic during the rush hour of about 200 street cars, 1800 motor cars, and from 10,000 to 20,000 pedestrians."

Page 167: Mr. Nelson P. Lewis discussed the rapid transit problem in his chapter on "The Transportation System" in The Planning of the Modern City.

"In a large city the trunk lines will carry such a heavy traffic that its accommodation on the street surface will be impossible unless it moves very slowly, and slow speed means restricted capacity. They must therefore be placed over or under the streets, on elevated structures or in tunnels. Some of the most important lines, also, will need three or four tracks to accommodate the traffic. Elevated roads offer serious objection to light and air and are noisy, and, as commonly constructed, disfigure the streets to such an extent that they will not often be tolerated. In the case of the elevated railroad in Philadelphia, which is built with a solid floor and is stone bal- 


\section{I74 LAND PLANNING IN THE UNITED STATES}

lasted, the noise has been greatly reduced. If the steel structure is encased in concrete, the disfigurement of the street is much less and the noise can be still further reduced. Of the latter class is the elevated railroad through the Fenways in Boston. The three-track elevated railway in Queens Boulevard, New York City, is composed of a series of arches between piers which are themselves pierced by arched openings designed to accommodate a double-track surface railroad. This street is 200 feet in width, the part in which the elevated railway is located having two roadways each $43 \mathrm{ft}$. wide, the space being $74 \mathrm{ft}$. in width, so that there is room for planting on each side of the elevated structure, which is itself $77 \mathrm{ft}$. from the side lines of the street, so that there is no obstruction of light and air, while with a solid floor, stone ballast and parapet walls outside the tracks there is very little noise. This is probably the best type of elevated railway yet built within street lines. While streets can rarely have such dimensions, if a few avenues leading directly out from the main centers of large cities were given a width of $x 50 \mathrm{ft}$. it would be possible to provide elevated lines of this kind which would be far more agreeable to ride on and would cost less to build than subways. Where underground railroads will ultimately be required and where they are built in advance of extensive development and before surface traffic is great, and where streets are sufficiently wide, they can be built in open cuts which need not be covered until the space above them is required for street purposes. In cases where the street width is sufficient the sides can be sloped and retaining walls omitted until the tracks are covered, and the space occupied by the slopes can eventually be used for additional tracks. The first rapid-transit subway built in New York had for the greater part of its length four tracks, on two of which express trains of ten cars are operated during the rush hours at intervals of one and three-quarters minutes with stations about one and a half miles apart and on the other two tracks local trains of six cars at the same intervals and with stations about a quarter of a mile apart.

"The elevated lines on both sides of the East River have been provided with additional tracks permitting the operation of express service in the direction of greatest travel during rush hours. With improved safety devices and methods of speed control and the additional mileage, the average number of passengers carried daily by the combined subway and elevated systems, on both sides of the river, has been increased from $2,273,737$ for the year ending June 30 , I 915 , to $3,886,7$ II for the year ending June 30 , I 921 , an increase of 71 per cent.

"This work has been done in connection with a comprehensive extension of the transit system of the city at an expense of about $\$ 330,000,000$, of which sum the city contributes about one-half, and the two traction companies operating the present lines the other half. Heretofore the building of new rapid transit lines has been confined to the parts of the city where population was dense and existing facilities were overtaxed. Under the present plans new lines are being carried into parts of the city which are still undeveloped. The effect of this policy upon taxable values will be very great. There may be a depreciation in certain congested sections where present high values have been brought about by a demand for space 
which exceeded the supply and congestion has resulted, but new areas will become available for development and there will be a diffusion of realty values with a considerable net increase. The original city-owned rapid transit line was 25.6 miles in length, with a total of 76 miles of single track. The extended system in operation in 1922 had a total of 206 miles of single track in subways beneath the city streets and in river tunnels, and 384 single track miles on elevated structures, or embankment, or in open cut, a total of 590 miles of track, while some 27 additional miles were under construction or authorized. . . . The crying need is transit of some sort which will put these (outlying) sections in close touch with the business centers. Rapid transit is the thing desired, while the manner in which it is supplied, whether over or under the street surface -it cannot be rapid if on the street surface-is a secondary consideration. 


\section{CHAPTER $\mathbf{X}$}

\section{TRANSPORT}

Entrances. Thoroughfares.-Time was when practically all the land entrances to town were by the highways. All the early books of travel in America by Europeans described the writer's first impression of the towns and cities from the vantage point of the highway which led into the city street. Then came the steam railway and the electric trolley which often provided new routes of entrance. With the advent of the automobile the highway entrance for both freight and passengers has again become important. These highway entrances usually occur where the country thoroughfare joins the arterial city street. That point is frequently marked by a change in the material and condition of the pavement, commonly to the disadvantage of the city street. Here, too, the interurban trolley tracks often switch from the roadside to the middle of the street, making a dangerous grade crossing. The only other indication that the "city limits" have been reached is a warning that the law against speeding will be enforced. From a purely business point of view in the enterprising towns where the citizens desire to induce travelers to stay, it would be worth some expenditure of thought and money to devise an arrangement that would eliminate the "death-trap," soften the warning, and automatically make each traveler glad to enter the pleasant precincts of a well-planned, well-kept town with a hospitable gateway.

In proportion to the opportunities for cities and towns to provide alluring entrances to their confines, very little has been accomplished. Of course in the conglomeration of towns which surround New York, Boston and Philadelphia, the traveler may 



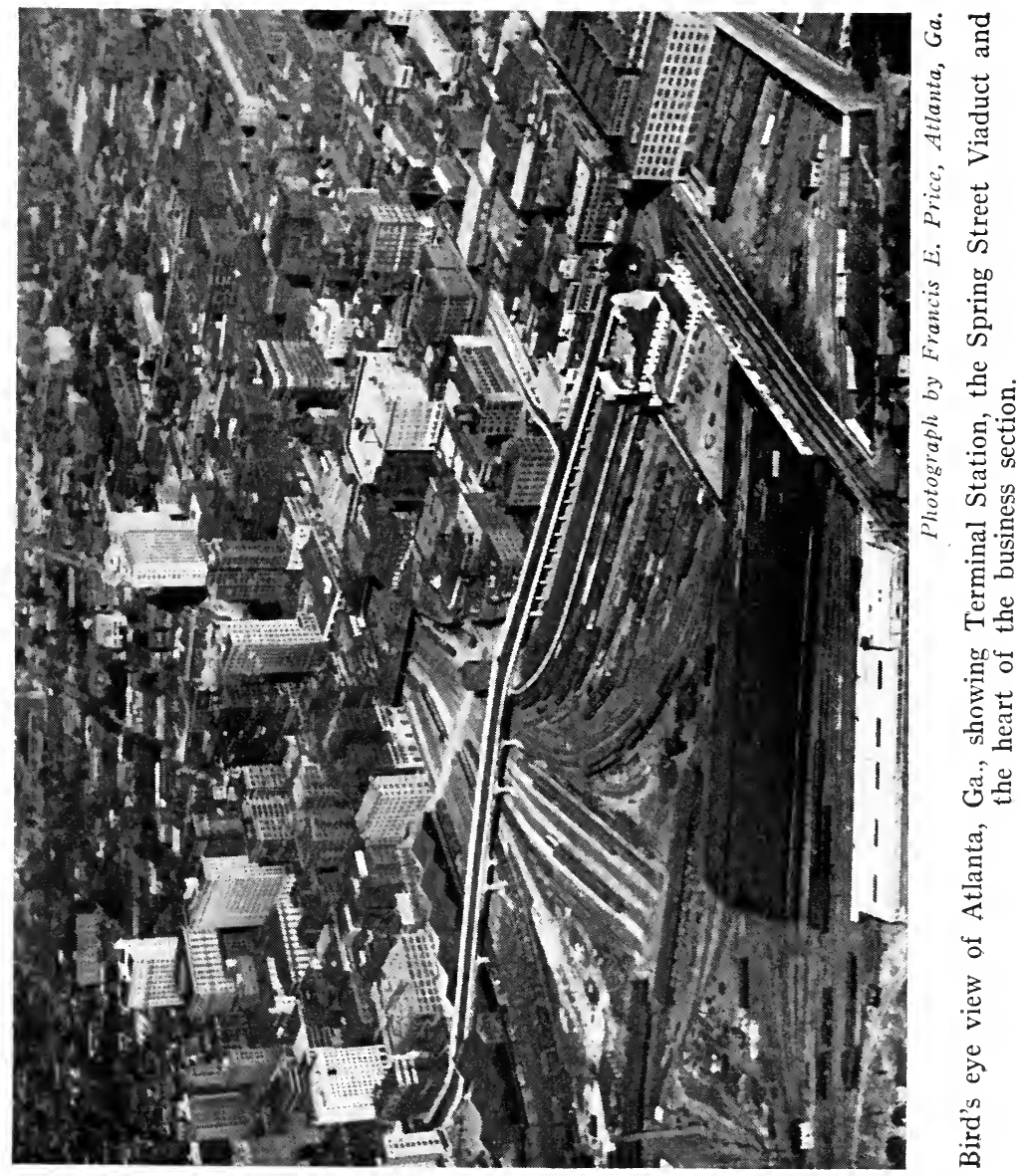


hardly know when he passes from the suburban towns and the satellite cities into the main metropolis; but those who have driven into these famous centers of population are apt to remember certain bottle-necks of congestion in which huge motor trucks, city delivery vans, clanging surface trolley cars and passenger automobiles jockeyed for precedence, though the exact point of entrance may never have been noted.

Speed the day when the city thoroughfares will be classified so that definite passenger and freight entrances may be established to the benefit of both classes of traffic. A little extra land on both sides of the highway just at the city limits might be transformed into a gateway of grass and trees which could be made more effective than a stone or brick affair. At any rate, the architects, the landscape architects and the artists could, if they were given an opportunity, devise suitable and effective gateways for the highway entrances to our towns and cities.

Entrances. Rail.-Usually the existence of a railway has led to the establishment, or at least the expansion, of the modern cities. Municipalities have bid eagerly for railways to build their lines into town. Many cities have put forth every effort and offered large inducements for railways to establish their terminals on land that seemed convenient to the then-confines only to learn (in a future generation perhaps) that the space occupied by switching yards and freight and passenger stations was exactly in the line of expansion. Many street traffic problems in the larger cities to-day have been caused in part by the location of the railway terminals, which have blocked the development of the down-town sections and contributed unnecessarily to the traffic in streets already overcrowded.

Chicago probably has the most difficult and complicated railway problem of any American city. There were in I9I 5, I94 square miles in the City of Chicago. Within that area, approximately 26 miles long and 8 miles wide, there were 2840 


\section{78 LAND PLANNING IN THE UNITED STATES}

miles of track. Seventeen hundred switching engines alone were used in the freight and car yards and forty thousand freight cars were handled daily. There are twenty-six trunk lines running into Chicago. In a small, congested area north of I6th Street the railways owned in I9I3, 250 acres, so arranged, as shown on the map, that the entire loop district was hemmed in by railway property.

Between the strip of railway-owned property along the Lake front and the great block of property owned by the railway companies in the down-town distirct there was (and is) a bottle-neck more than a mile in length, averaging for over three-quarters of a mile scarcely 1200 feet in width and for another third of a mile something over 2000 feet. In fact the $32.5 \%$ of the two-mile square business district of Chicago which is owned and occupied by the railways is responsible for the fact that only four out of twenty-four north and south streets extend the two miles between Chicago Avenue and Roosevelt Road. Imagine the traffic of the great South Lake Shore district of Chicago pressed into three main streets and most of it into the broad and smooth Michigan Avenue, as on Wabash Avenue there are both elevated trains and surface cars. Moreover there is no Wabash Avenue bridge across the Chicago River. State Street with its congested local traffic and its narrow width north of the river hardly offers an acceptable alternative through route. It is estimated that approximately 73,000 automobiles a day cross the Michigan Avenue bridge, of which 18,000 go through the loop without stopping. Of the 55,000 vehicles which do stop, 4I,000 stop west of State Street. That is, if it were not for the extent and location of the railway property, often referred to as the "Chinese Wall," this traffic would be distributed among other north-and-south thoroughfares.

To correct this situation it is proposed to widen $\mathrm{La}$ Salle Street to 108 feet all the way from the Station to Lincoln Park. Eventually it is planned to extend La Salle Street south through the railway property, as a part of the proposed south-side 
terminal development. It is planned to make this section of the street ${ }_{50}$ feet wide.

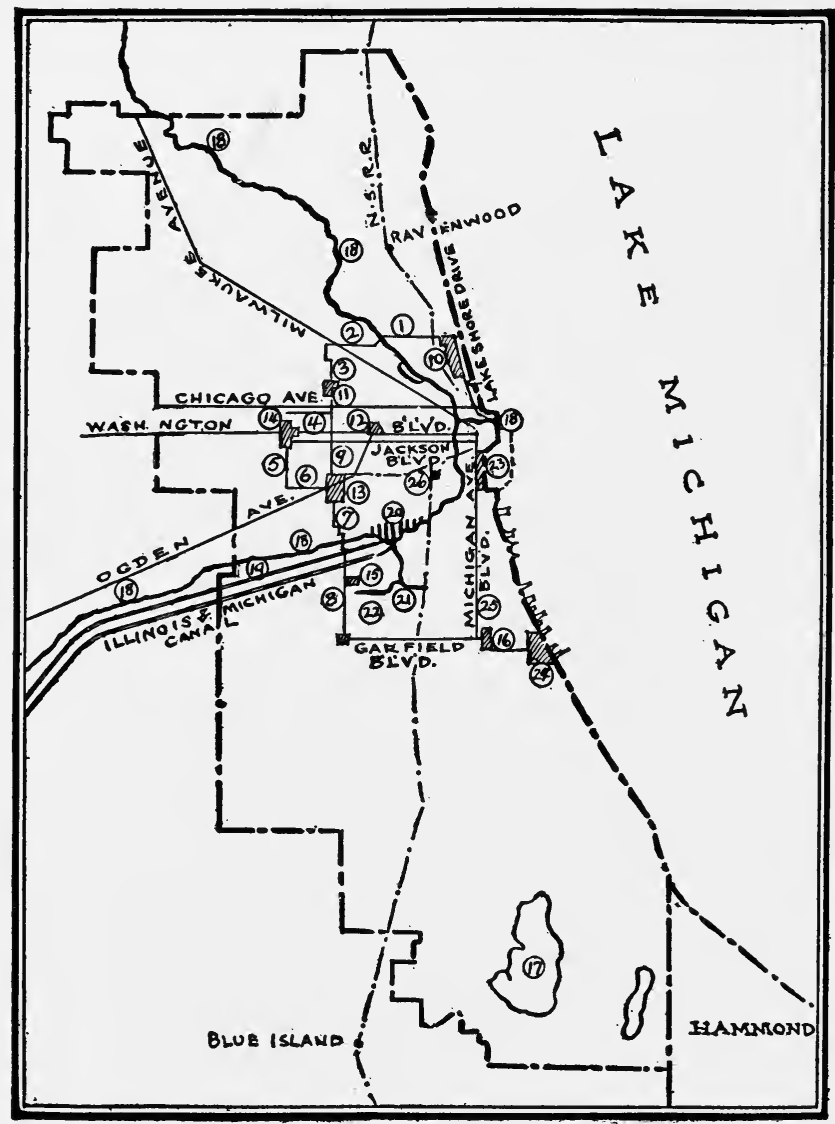

\section{Chicago}

I-I6, 23-24 Parks and Boulevards; I7 Lake Calumet; I8 Chicago River; I9-20 Canal; 2I Packing Houses; 22 Stockyards; 25-26 Places of Interest.

Among the original proposals of the Chicago Plan was one to enlarge the business area by pushing the railway stations south to I2th Street and one to straighten the Chicago River 
which bends toward the bottle-neck of traffic, in order to open up several additional north-and-south streets. In I923 application was made by the municipal authorities to the Federal Government to grant the necessary permission to straighten the south branch of the Chicago River between Polk and i8th Streets. When this is done five loop streets will be extended from their present termini through the area now absorbed for railway uses.

In Chicago an imposing new Union Station to serve five of the twenty-six railways has been erected where it may be approached by Canal Street destined to be the western boundary of wide streets leading around the central business district. "The great freight terminals will lie to the south of the station. Concrete and steel viaducts, dock walls for the Chicago River, and a widened Canal Street are all included in the plan," which will cost some seventy-five million dollars.

In New York the trains from the south enter the Pennsylvania Station of the Hudson Terminal. In both cases the tracks are underground. The New York Central group of rail entrances from the north terminate at the Grand Central Station, which occupies the space between 42nd and 45th Streets. The station stands directly in the line of Park Avenue but an esplanade approached by ramps carries through vehicular traffic around the building on a level above the surface. The open switch yards which were once such a nuisance have now been placed underground and electrified so that the eleven cross streets which once were interrupted are now carried over the tracks. The open space under the old arrangement occupied a width of 350 feet; the new terminal has been widened to $8 \mathrm{I} 7$ feet and provision has been made for local trains below the main track level.

But perhaps the most interesting feature of the Grand Central Terminal is the fact that several huge buildings have been erected directly over the tracks and so provided a profitable investment to offset the enormous cost of the station and its terminal facilities. Moreover, upper Park Avenue, where 
for many years residents were annoyed with smoke and noise of the constant succession of trains which traversed the open tracks, is now one of the exclusive house streets in New York. With the tracks depressed and parking strips in the center the street is one of the most imposing in the city.

The arrangement of the Union Station in Washington, where all railways enter, is excellent. The terminal trackage is located where it may be possible to maintain it above ground for many years, if not indefinitely. A lower level is used for direct station entrance of through trains; but the terminals and switching yards are above ground. The station is close to the Capitol but about a mile removed from the retail business center which is expanding in the direction away from the station. The tracks from the south are elevated where they cross Potomac Park which borders the Potomac River and depressed where they traverse the city development. They approach Union Station by way of a wide circle which makes them as little objectionable as possible. There are quite extensive switching yards for the Pennsylvania Railroad, the Baltimore and Ohio and others, located in an area but little used at the present time.

Rail Service for Industrial Sections.-But if through railways and switching yards are a nuisance to residence neighborhoods unless they are placed under ground and electrified, they are a real asset to industrial districts. Many industrial plants are located almost solely with reference to loading facilities. If we may accept the statement of Mr. George R. Wadsworth, "There are many industrial localities but few developments." $\mathrm{He}$ defines an industrial development as a "Productive community, self-contained from the receipt of the raw material to the shipment of the finished product, with common interest among the several producers as to the elements of general facilities covered by rentals, power; taxes, insurance, and transportation facilities."

The Bush Terminal is the exception. Located in South Brooklyn on New York Harbor it has ample power facilities 


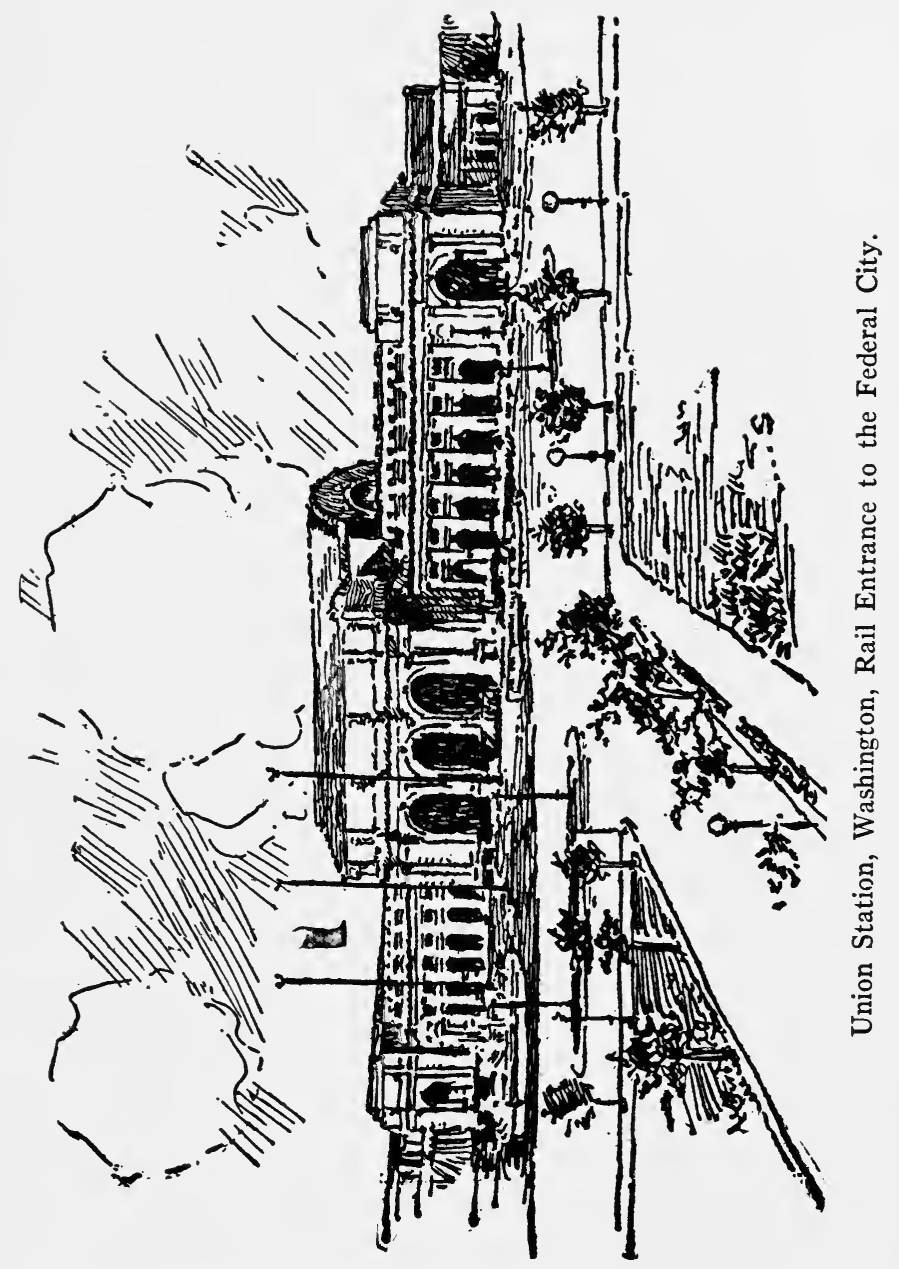


and rail entrance, direct or indirect, to all trunk lines entering the New York City terminal district.

In cities which are entered by a number of different railway lines, an industrial belt line which permits cars to be routed from the industrial district or districts to any one of the main lines provides a convenient service and relieves the congestion of tracks and haulage through the streets of the central city.

In any case no adequate city plan would permit railway lines and terminals to divide the city into sections. Chicago has suffered seriously from that situation and while the adjustments devised by the Plan Commission and the railway companies mitigate many of the evils no one can believe that the business district of Chicago would not be better off if the railway property were better located and it seems equally true that the railway companies themselves would profit by a better arrangement. If Chicago were to begin again and plan for the best use of unoccupied territory there is no doubt that a very much better arrangement could be found. The provision for track terminals, both passenger and freight, when they are located in towns and cities, should include two-level crossings and should be placed in proper relation to the sections of the city which will be served by them.

Grade Crossings.-The danger of grade crossings is so generally recognized that it will not be many years before they will be absolutely prohibited at the intersections of all city streets, main country highways and much-traveled railway lines. At Pullman two trunk line railways crossed a street at grade about half a block from the main entrance to the Pullman works. "Between two and three hundred trains a day, including the suburban service, pass(ed) over these tracks, two of them being through trains running at full speed across the street within a few minutes of 5:30 in the afternoon, which is the quitting time for 9,000 employees. It is said that in 22 months 4I fatal accidents occurred on these and other crossings in the vicinity and, when the public realized the 


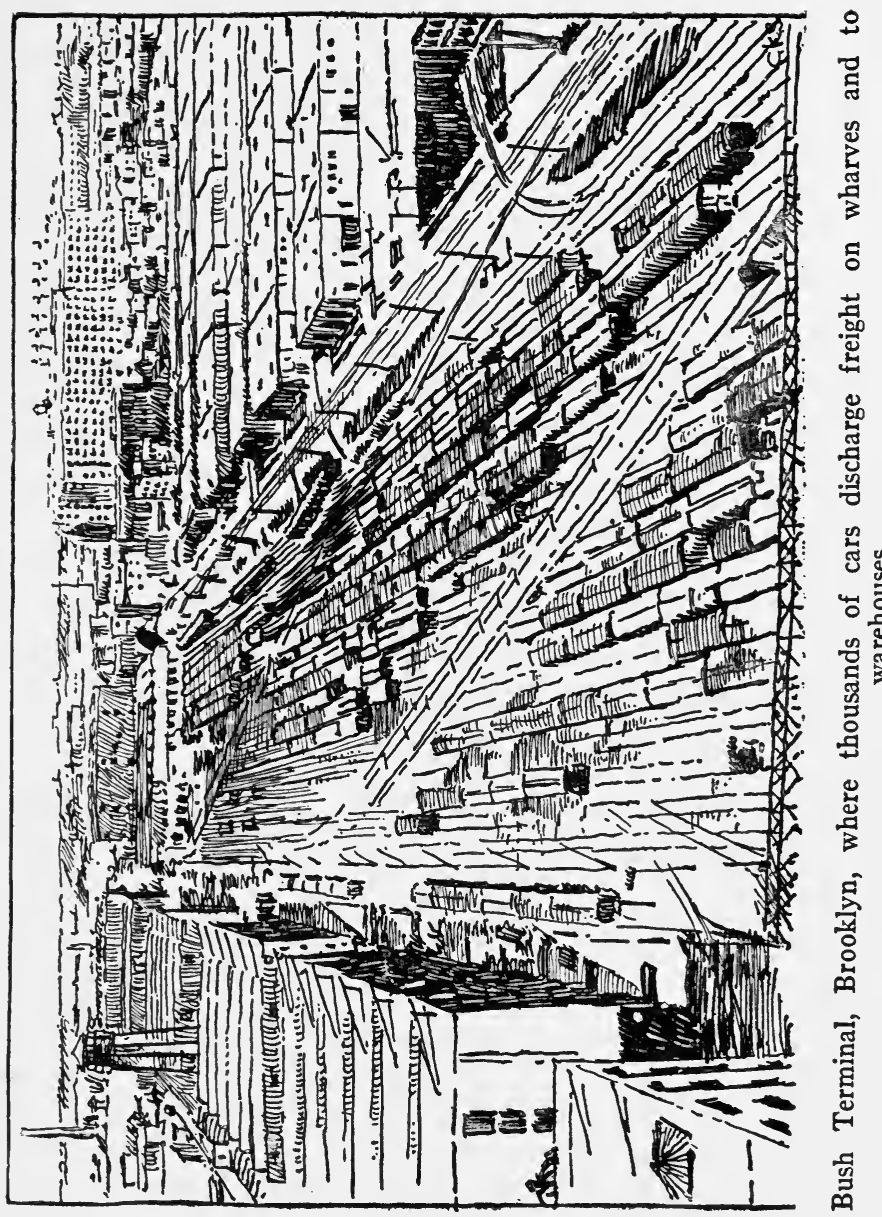





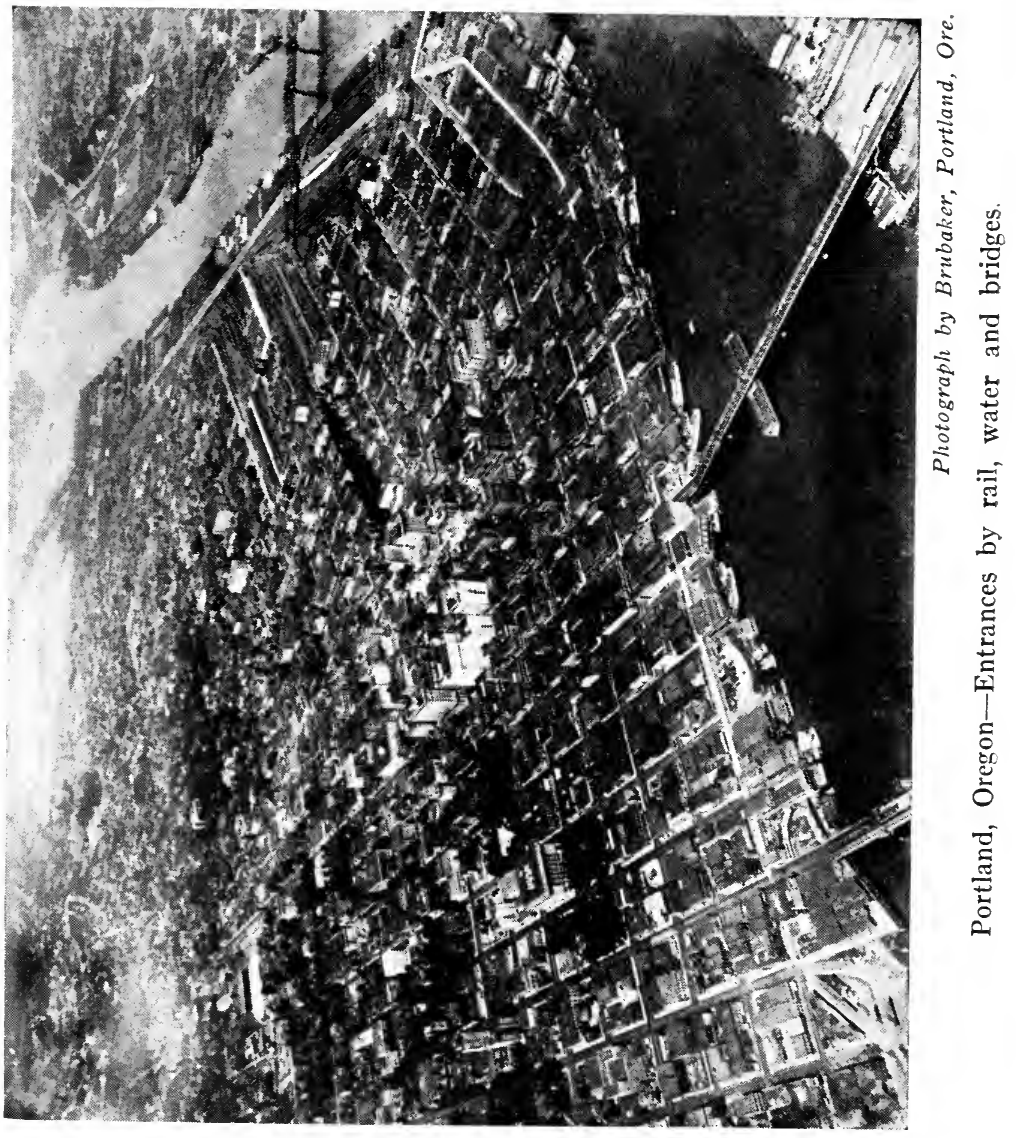


extent of the slaughter which was going on, an agitation was begun which led to the adoption of an ordinance requiring the elevation of the tracks before the close of the year 1916." We have come to realize that it is impossible to make such a grade crossing safe. The only security lies in the double-grade which separates pedestrians and vehicles from train traffic.

There are now few States in which new railway tracks can be constructed which cross main highways and city streets on the same level. "The problem," says Samuel T. Wagner, "is how are we to get rid of the old grade crossings that are in existence?" Mr. Wagner calls attention to the fact that the construction of two-level crossings demands a high grade of engineering skill, involving construction and location of railways and highways, bridges, sewage and drainage problems, construction of retaining walls, electrical and mechanical engineering problems and sometimes in involved problems the reconstruction of railway yards, passenger and freight stations and locomotive and car facilities which may be affected by the changed conditions.

The highway may be lowered under the railway or raised over it; the highway may be lowered and the railway raised or the highway raised and the railway lowered; the railway may be raised over the highway or lowered under it.

The expense of converting existing grade crossings into twolevel crossings would amount to an enormous sum of money; but every year a considerable number of grade crossings are eliminated so that the planning for the future may be directed to scientific locations of tracks and highways and streets to reduce crossings to a minimum and to insure proper treatment of necessary intersections.

Entrances. Water.-Most of the important cities of the United States have water entrances. The Atlantic and the Pacific ports serve the ocean traffic. The tonnage moved in the Great Lakes is nothing short of stupendous and it will not be many years before the great ocean carriers will enter the Great Lakes and so join Chicago, Milwaukee, Cleveland 


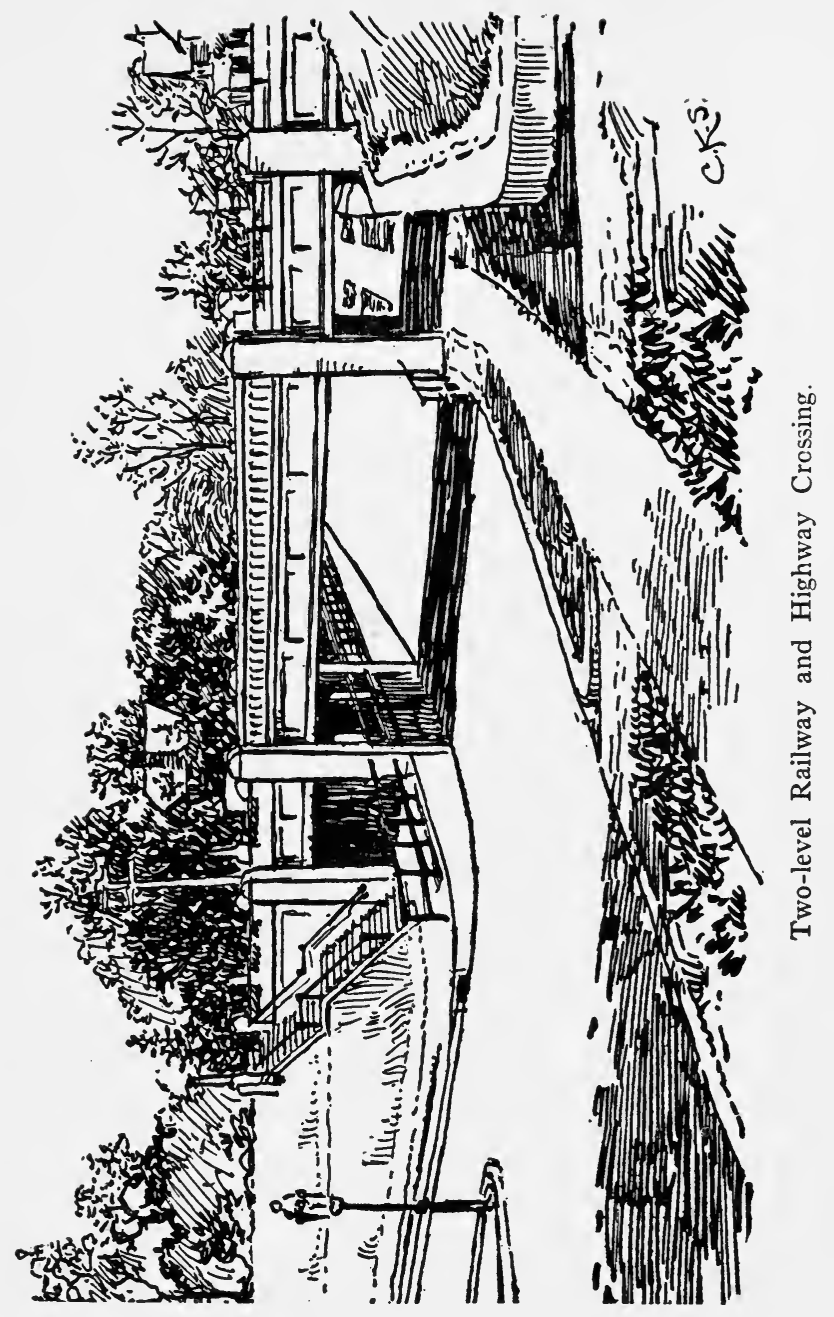


and other Lake ports with London, Europe, South America, and Africa by direct steamer.

The provision of modern wharves with proper equipment for loading and unloading and with direct track connection with the railways is one of the most important assets which any city can provide to attract commerce. The planning of the space which should be assigned to commerce, industry, parks and other purposes is a community problem, though too often neglected. Every city should own and control its water front. Only through such public control can a proper balance be maintained and the greatest use secured of river, lake and ocean frontages. Chicago lost many miles of its lake front to a railway; but is now building land to serve for park and boulevard connections out beyond the railway tracks. The beautiful Field Museum is on a site extended into the Lake and the new Illinois Central Railway Station will be locaied not far from it. It is expected that a system of wharves will be developed.

It is possible to plan for a two-level water-front which furnishes wharves and streets for heavy hauling below and a pleasure boulevard above. The Chicago river is to be treated in this fashion. Riverside Drive skirts a bluff, while down below are railway tracks and wharves, though the appearance of the lower water-front leaves much to be desired.

In a distance covering nearly four miles of the lower New York water-front, the proportion occupied by the different services is as follows:

Per cent

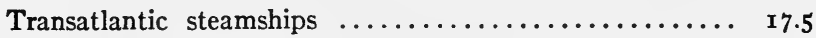

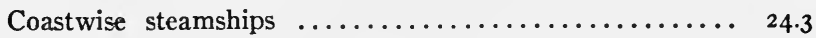

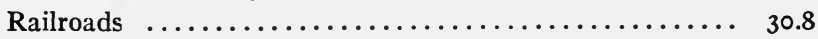

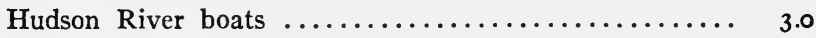

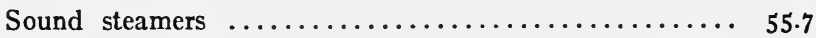

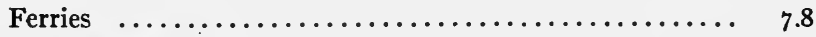

Open wharfage $\ldots \ldots \ldots \ldots \ldots \ldots \ldots \ldots \ldots \ldots \ldots \ldots \ldots . \quad 3.9$

Miscellaneous: coal, ice, dumps, oysters........... 6.9

Recreation piers $\ldots \ldots \ldots \ldots \ldots \ldots \ldots \ldots \ldots \ldots \ldots \ldots$. 1.0 
In an industrial city with a water-borne traffic it can readily be seen that one or more industrial districts should be assigned to the water-front but a good city plan would in almost every case bring about a better arrangement than exists in some of our American cities where the entire water-front of a river or harbor is lined with a broad strip of industrial establishments which effectually cut off the whole population from any other use of the water-front, either for parks, boulevards or pleasure craft. In Harrisburg, Pennsylvania, there is an excellent division of the river frontage which will allow indefinite expansion of industries in one direction and of residences and boulevard development in the other.

In many cities with considerable water-front the land has been extended into the water by dredging deeper channels and by filling the marshes or swamps. An entire peninsula has been reclaimed from the Potomac River in Washington, thus enclosing the harbor on three sides. The present line of the San Francisco water-front is said to be extended into the Bay far beyond the line which existed in the Gold Days. The harbors of Seattle and Los Angeles have been improved by dredging and filling to reclaim new land.

The designing of proper slips and wharves to fit the various waterways is a matter which requires great technical skill. In industrial sections there have been built, in some instances, great terminal wharves which not only have brought railway lines and ships to a common transferring ground, but, in the case of the Bush Terminal, have provided facilities for manufacturing raw material received into finished products to be shipped. In connection with the plans for such industrial railand-water terminals or for great systems of passenger and freight wharves, the streets must be most carefully laid out if they are to serve the fullest usefulness. In so far as passenger traffic can be segregated from the heavy hauling of freight both classes of traffic will be benefited. Much street traffic, of course, will be avoided, if freight cars can be loaded directly from incoming boats. The day may come when good planning 



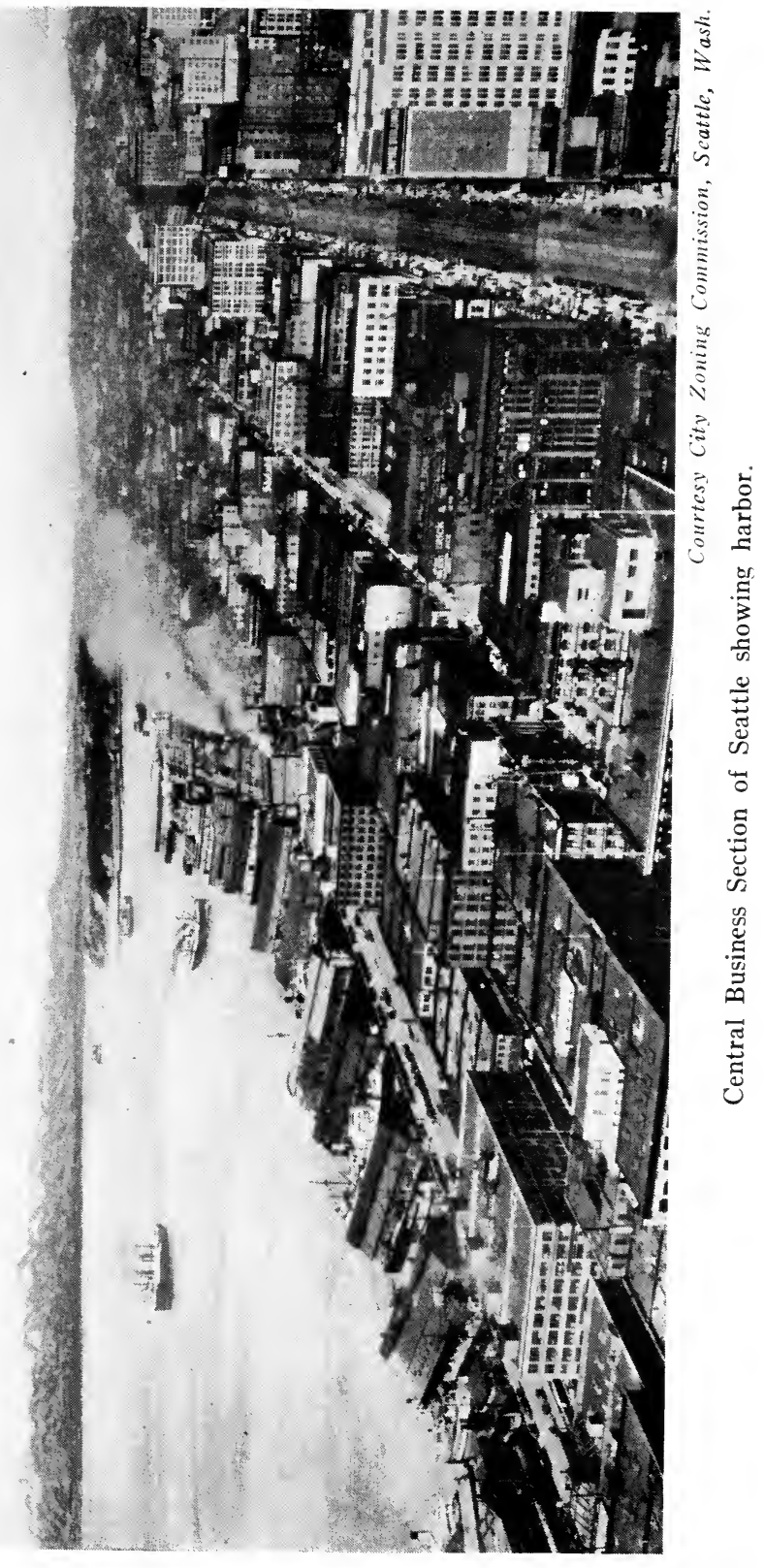


will make it possible for passengers to be transferred from shipboard to rail coaches.

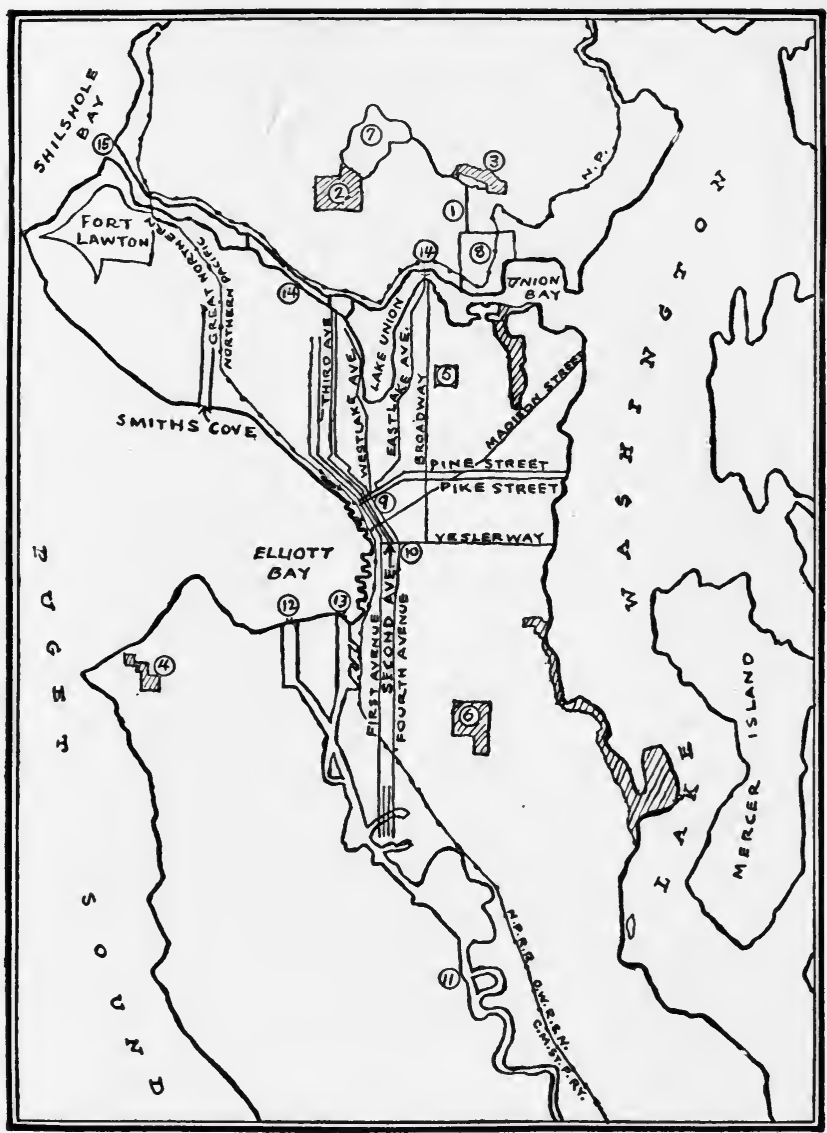

SEATtLe

I University Boulevard; 2-6 Parks; 7, II-I5 Waterways; 8 Washington State University; 9 Post Office; ro Depots.

The intimate connection between types of wharves and piers and the machinery for loading and unloading freight and the natural and manufactured resources of the community will at 
once be apparent. A commercial harbor should be planned to meet the local requirements and should be furnished with facilities to fit the freight to be handled. Mr. Goodrich lists the various interchanges which wharf structures must ordinarily be designed to provide under different conditions.

\section{Ocean to rail \\ Ocean to truck \\ River to rail \\ River to truck \\ Canal to rail \\ Canal to truck \\ Ocean to river \\ Ocean to canal \\ River to canal}

Entrances. Bridges.-The entrance from one or more directions to the river cities is sure to be by way of bridges. Usually the rail and highway bridges are separate, though the rapid transit and interurban tracks are frequently laid in the space provided for free-wheel traffic. These bridges are apt to be bottle-necks of congestion unless the entire arterial highway and railway systems within the municipality are planned to articulate with the bridges and unless sufficient crossings are provided. Entirely apart from the primary utilitarian uses of such entrance bridges, the river cities have a valuable opportunity to build bridges which shall stir the imagination and prove worthy gateways to their confines. There are far too many bridges which, together with their approaches, give the visitor the impression of a back-door entrance.

Entrances. Air.-Cities are already beginning to compete with each other for terminal stations on the trans-continental aerial mail route. As the air service comes into more common use for carrying mail, passengers and express, the need for landing stations will become more urgent. It may possibly be that the future will see types of air craft which can be safely tucked into neat little berths on the tops of our skyscraper buildings; but at the present time a reasonable area of land 


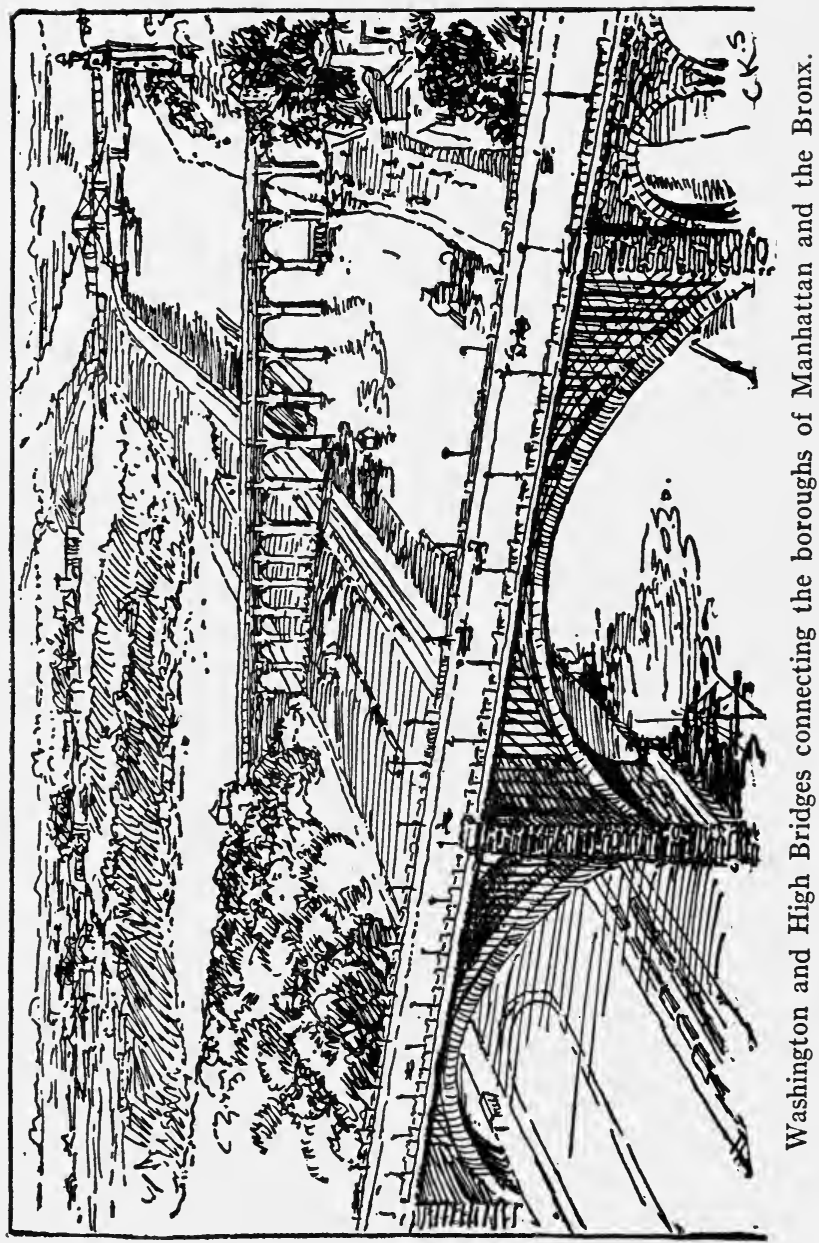


is necessary to provide proper landing stations. "Location 'on the airline' is destined to become of great importance to all cities and probably of vital importance to the lesser cities," declares Mr. Archibald Black.

"Strange as it may sound, most cities have only a few sites which are entirely suitable for air terminal purposes. If these are left to be developed by some air transportation corporation, tomorrow the city may find itself at this firm's mercy so far as rapid inter-city transportation is concerned. The obvious solution is the provision of an air terminal owned or controlled by the municipality and open to all on even terms. Hangar space and other facilities can be leased to private owners, small operators, and also to air transport firms when the latter serve the city in question. . . . Several of the largest cities in the country, such as Chicago, Philadelphia, Detroit, Boston, Kansas City and many others, have already given serious consideration to this problem. . . . Detroit recently passed a referendum authorizing the city officials to construct 'several aviation fields.'"

The accessibility of the airplane landing fields is of great importance in selecting terminal or way-station sites for fast air mail routes. Between Washington and New York it was found that the time consumed in transporting mail to and from the landing stations made it impossible to offer much quicker service than the train mail schedule.

The selection of an air terminal presents a nice problem in planning. The site, according to Mr. Black, should be considered from the point of view of its adaptation to airplane, seaplane and airship use; location in relation to other air stations, the airway and the city and extent to which the terminal may be used. Meteorological conditions should be studied, soil and drainage are important; transportation and communication facilities as well as available water supply and electric power should be considered. And finally the cost of the property enters into the problem as an important item.

The layout of the field is an extremely technical matter and should require the advice of the specialist-the field landing engineer-in addition to the general planning and engineering aid. 


\section{SUGGESTED READING}

"Smoke Abatement and Electrification of Railway Terminals in Chicago." A Report of the Chicago Association of Commerce Committee of Investigation on Smoke Abatement and Electrification of Railway Terminals, Chicago, 1915.

Walter D. Moody, What of the City? Chicago, Igrg.

Frederic A. Delano, "The Chicago Plan, with particular reference to the Railway Terminal Problem," in Journal of Political Economy, November, I9I3, vol. 21 .

Charles H. Wacker, An S-O-S to the Public Spirited Citizens of Chicago. February I6, I924.

How the La Salle Street Improvement Affects You, Chicago Plan Commission, March 3, 1924.

"Chicago, the Great Central Market." The Chicago Plan.

George R. WAdsworth, "Railroads and Industrial Districts," in City Planning, edited by John Nolen, I916, Chap. XII, p. 264.

Samuel R. Wagner, "Railroad Grade Crossing Elimination," in the American City, November, I920, vol. XXIII.

E. P. Goodrich, chapter on "Navigable Waters," in City Planning, edited by John Nolen.

ARCHibald Black, "The Municipal Air Terminal," National Municipal Review, March, 1923, vol. XII.

ARCHIBALd BlaCK, "How to Lay Out and Build an Airplane Landing Field," in the Engineering News-Record, September 28, I922, vol. LXXXIX.

\section{NOTES}

Page 178: Concerning the situation in Chicago and other similar conditions, Mr. Frederic A. Delano, writing in 1913, suggested certain remedies:

Said Mr. Delano: "Railway managers are coming to the decision that expensive and extensive terminals are neither proper nor justifiable from any standpoint. There is a growing belief, especially in respect to suburban traffic, that there is no need of terminal facilities at all, but that by through-routing or continuous movement of trains, the public would be better served and at less cost to the railways. Depots, with their elaborate comfort facilities, are obviously necessary for long-distance travel, but with terminal stations relieved of the burden of suburban trains, less space would be required. Recent development in electrification, which is likely to come into use ... opens up a good many new possibilities; and one of the advantages (or, as it might be called, a 'by-product') of electric traction is to be found in the fact that, with the avoidance of smoke and steam and the gases of combustion, it is possible to utilize the space 


\section{I94 LAND PLANNING IN THE UNITED STATES}

over tracks for general building purposes. In this connection witness what is being done in New York City over the New York Central terminal. This clearly points to the fact that terminals, while enormously expensive (on account of the value of the property taken and the massive construction required), can yet be made, partially at least, self-sustaining. Another fine example is to be found in the Church St. Terminal office building of the Hudson Terminal Railway in New York."

Concerning the handling of freight Mr. Delano laid down four general guides:

"First: So far as possible, freight in transit to points beyond, whether in carloads or in small packages, must not be handled in the busy portions of the city. This problem is being dealt with and is in a fair way to be solved . . . in the so-called 'Clearing' yard outside the city limits.

"Second: It is just as important that the railway freight stations should bear some interrelation as it is that passenger stations should. Indeed it might be said to be even more important, because human beings have the advantage of mobility, whereas freight must be moved by some vehicle or form of conveyance.

"Third: In respect to the freight business, as with the passenger, there must be an interrelation between other means of transportation, whether by roadway or waterway.

"Fourth: The expenditures necessary to create these facilities must be justified by more economical methods or improvements in service."

Page 180: "The passenger terminal will house trains of both north and south approach. Above the train sheds will rise a monumental structure bounded on four sides by a colonnade and crowned by a lofty office building.

"The site for Chicago's new main post office is the two-block area on Canal street between the Union Station and the Chicago \& Northwestern Station, already completed, which together handle sixtytwo percent of Chicago's mail. . . .

"Another great railroad development is under way at the southern edge of the central business district. The Illinois Central Railroad is spending eighty-eight million dollars in the electrification of its facilities and the construction of an immense new passenger depot, fronting upon Grant Park at Roosevelt Road and Indiana Avenue, west of and adjacent to the new Field Museum and Stadium. This forms part of the lake front development of the Plan of Chicago; a project which also provides for the future development of harbor facilities along the shore of Lake Michigan between the Roosevelt Road and 47th Street."

Page 187: The improvement of harbors involves many technical problems, a few of which are suggested by Mr. E. P. Goodrich:

"Failure . . . to provide such protection as is afforded by a welldesigned breakwater has been known to give a port such a reputation that shipowners and captains were forced to shun it. The careful laying out, maintenance, and buoying of channels is of almost 
equal importance, and in some instances taxes the ingenuity of engineering skill to the utmost. The constantly shifting channels in the great inland rivers are well-known phenomena, and the necessity of ignoring natural channels to a large extent, sometimes creating channels for themselves, is said to have dictated the design of the shallow-draft, stern-wheel Mississippi river boat.

"Lighthouses, smaller beacons, lighted buoys, fog horns, sirens, and other safety devices must be considered in connection with waterfront developments of any maznitude, and there is ample opportunity for the city planner to combine the latest scientific development with a treatment which is pleasing to the eye of the artist and satisfactory to the layman. Anchorage grounds must be provided wherever fleets need to be thus accommodated, and in some instances mooring dolphins are found advantageous, at which vessels can tie whenever the major part of their cargo is to be transferred to other water craft. ... Many harbors are ... provided with turning basins. Examples are to be found at the inner end of the socalled canal designed for the Newark Harbor improvement. A turning basin is also provided in connection with the inner harbor at Los Angeles.

"The transatlantic piers on the west side of Manhattan Island, New York City, in the so-called Chelsea district, are well known for their adequacy as combined passenger and freight piers for vessels of the largest type. An interesting design which was developed in an effort to accommodate practically all of the several varieties of interchange listed above is to be found at Portland, Oregon, where both ocean-going vessels and river craft are found, where a railroad spur touches the dock and motor trucks and horse-drawn vehicles are accommodated, and where so great a range of water level occurs yearly that a two-level structure is required. . . .

"The unloading ore docks at Ashtabula and Buffalo, and the oreloading docks at Marquette, are known the world over, while the grain elevators at Duluth and Montreal have been widely pictured. The new designs for the port of Seattle include special accommodations for fish, lumber, grain, and fruit, in addition to a development of ample proportions for misceilaneous cargo. New Orleans has lately started special cotton-shipping warehouses, with equipment of the most modern and economical type." 


\section{PUBLIC PARKS AND OPEN SPACES}

Public parks and open spaces have become as much a necessity in our modern cities as streets and building lets. Like the streets the parks have become somewhat specialized and need classification. The term park has come to be a generic designation which includes a number of highly differentiated species.

Since the early days there have been in American cities open spaces-the "commons" of New England, the "squares" of Philadelphia and Baltimore, the "circles" and "triangles" of Washington. In time these patches and stretches of green were surrounded by busy streets and business buildings.

As the American towns grew into cities there was usually reserved or purchased in the outskirts a fairly good-sized park, perhaps several hundred acres, possibly more. This was the park. Horse cars and later cable and electric cars brought citizens to the park gates. A few driveways were provided for the affluent who rode in carriages drawn by high-stepping pairs of bob-tailed horses and for the more modest and more numerous families who rode in one-horse surreys, phaetons and "buggies." An entire afternoon was quite easily occupied in driving out through the park, lingering under the trees in remote lanes and home again. In the park there were places where picnic parties spent the day in the country though picnic equipment was seldom provided. There were by-paths through which those who walked or tramped could ramble for hours.

Two separate and distinct forces began to make these parks inadequate as time went on. First, instead of being somewhat remote country parks, the population surrounding them pressed 
in on all sides and they were transformed into neighborhood or sectional parks. They lost much of their country character through intensive use. Certainly when the near-by population filled the stretches of green with thousands of human beings those who lived several miles away ceased to make much use of the park. Other parks were needed. Central Park in New York has passed through this period to some extent. The fact that the park lies directly in the path of an enormous volume

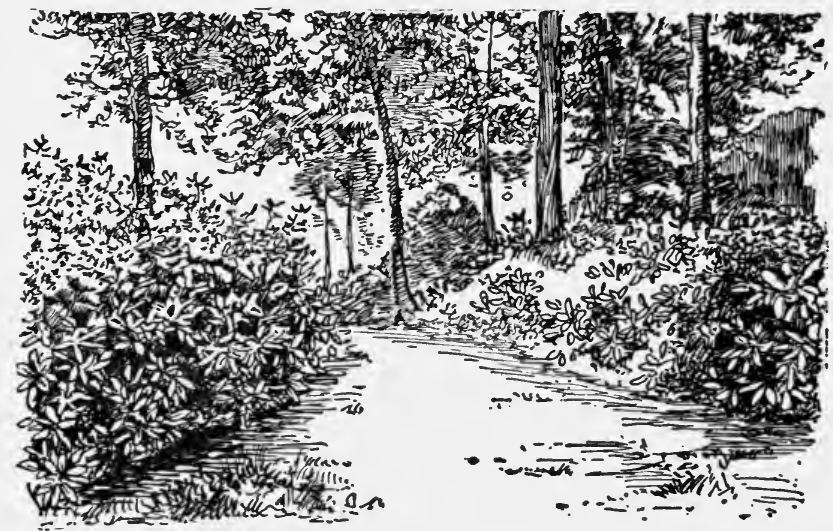

Shady paths in Branch Brook Park, Newark.

of traffic and that a great proportion of that traffic uses the park driveways as main thoroughfares conspires further to rob the park of its quiet, restful influence. Druid Hill Park, Baltimore; Rock Creek Park, Washington and Golden Gate Park, San Francisco, for all their size and for all the charm of their wooded areas are in process of being transformed into city parks with a patronage from the populous areas immediately contiguous. It will soon be necessary in these three cities to provide other larger parks further from the built-up sections.

The second force which has rendered these country parks inadequate has been the longer range of the automobile and the demand for far-flung parks. In President Roosevelt's day driving or riding through Rock Creek Park constituted an 
expedition to the country. To-day a motorist may drive from one end to the other in less than half an hour. Twenty years ago it was a real journey to drive or walk from the foot of Golden Gate Park to the ocean. To-day it is but a few minutes drive to spin along the entire length of the park to the Cliff House.

With the growth of the really great metropolitan areas, made up of many small cities overlapping and encroaching on each other the need for a system of parks to serve different purposes but connected by parkways and boulevards has come to be understood. The Boston Metropolitan Park System, outlined forty years ago, is now used by hundreds of thousands of people. Chicago began to build a system of parks connected by boulevards as early as 1869 . Other cities have followed until every progressive city in the United States is striving to create a Park System-an inner and an outer chain of parks connected with strips of green parkways bordering pleasure drives.

With the increasing popularity of out-door recreation we have not only parks and play spaces devoted exclusively to recreation purposes, we have the municipal forest reservations, primarily to preserve stream flow and wooded areas to hold the moisture, which offer the most varied and interesting recreational possibilities. Many cities are providing extensive outer parks and forest reservations. The Board of Commissioners of the Forest Preserve District of Cook County has already acquired since 191 6 more than 25,000 acres. In 1922 it was estimated that some five million people visited the Preserve and were taken care of. The forethought and planning which are responsible for these extensive recreation spaces will prevent the future generations from too great congestion in some sections at least. It is in the down-town districts of our great cities and in the crowded neighborhoods that parks and play spaces are limited. And it is in precisely these areas that land values are so great that it is difficult to create new parks. 
The classification of Public Outdoor Recreation Areas presented by Professor Henry V. Hubbard covers the main types which have developed during the last half century.

“(I) The 'Reservation,' a municipal holding of country land, perhaps in connection with city forests or city water supply, made accessible by roads, it may be, but not yet developed for intensive recreational use, and frequented mostly by picnic parties and others spending several hours at a time in the open.

“(2) The large park, or 'country park,' designed to give, as far as is consistent with fairly intensive use, all the sense of freedom that the unspoiled country gives, and being the nearest thing to unspoiled country that most of the city dwellers can commonly take time to enjoy. It is fitted to receive large crowds and not to be destroyed by them, and indeed not to be crowded by them, for its main use is still to relieve a man from too close contact with his fellows.

“(3) The small park, or 'intown park,' more accessible but less extensive, not pretending to a countrified appearance, but depending upon its design, its foliage and flowers, even upon architectural accessories at times; providing amusements, which can be enjoyed by crowds and making the crowd a part of its design. 'Commons,' 'public gardens,' many of our larger so-called 'squares,' are of this type. Our 'parkways,' which serve as pleasure traffic connections for our large parks, have a local use in some cases like small parks.

"(4) The playfield, for the active play of adults and young people over twelve, in games taking considerable space, like baseball, football, tennis, track athletics, etc., under supervision.

"(5) The boys' outdoor gymnasium, or restricted playfield, for very intensive use by boys over twelve, with apparatus, such as parallel bars, ladders, etc., and a supervisor.

"(6) The girls' outdoor gymnasium, for intensive use by girls over twelve, with giant strides, swings, etc., and a supervisor.

"(7) The children's playground, for boys and girls under twelve, with sand pits, baby hammocks, etc., and a woman teacher in charge.

“(8) Special facilities depending upon local opportunities, such as swimming pools, wading pools, skating ponds, facilities for bathing in lake, river or ocean."

Thus the modern city would be provided with many small children's playgrounds placed approximately half a mile apart so that no child would need to come a distance of over a 
quarter of a mile. The playgrounds and playfields for the older children should be scattered over the map of the residential sections at intervals of about a mile, depending somewhat on density of population. The "intown" or neighborhood parks are coming into increasing popularity. The small parks of the South Side of Chicago have become justly famous for their efficient service to the residents. Only too often the location of these neighborhood parks is left to chance or they are omitted from plans for residence districts. In the larger cities there will be the need for several of the large, country parks to serve sections far removed from each other. The location of these has in the past usually depended upon occasional gifts, the purchase of estates which were on the market or some other reason not related to the city plan. It is now rather generally recognized by city planners that the setting aside of the larger park areas is a part of "laying out" new towns or suburbs.

The ravines of small creeks and streams are ideal for park purposes and not much use, at least without great expense, for building purposes. Not only do the stream-beds offer excellent recreation but the residence lots facing on such reservations are usually enhanced in value and certainly offer building sites which are much sought after. Parks so located generally preserve natural wooded strips which would be totally destroyed if the land were filled and put to any other purpose.

The location and distribution of these various park and play spaces is closely related to the street system. The small playgrounds will usually be able to avoid the main traffic streams. It is obvious that small children should not be obliged to cross main thoroughfares in going to and from the playgrounds. The areas between main traffic streets should usually be developed as units complete within themselves so far as local playgrounds and neighborhood parks are concerned.

It is obvious that where parks occupy more than one block they should not lie directly across heavy traffic arteries. Professor Hubbard suggests that automobiles should not carry 
people through the park except where this can be done with little interference with the primary function of the park, though they should carry people $b y$ the park and to the park. The design of the pleasure drives bordered by parkways and connecting the many parks and reservations of the Boston Metropolitan System makes it possible for the through traffic to skirt many of the areas and at the same time provides access to those who wish to enter the park.

The development of pleasure drives and boulevards connecting a balanced park system automatically segregates traffic to some extent and if the parks and drives are well located in relation to the heavy traffic ways and the direct passenger routes the parks and parkways may exercise a very potent influence in the solving of traffic problems.

Transportation and Parks.- There has been much misunderstanding concerning the relation of transportation to parks. Professor Hubbard has analyzed the problem carefully.

"The railroad is on the whole the enemy and not the friend of the park in its immediate relations. There are plenty of instances of course, in the cases of the larger parks and particularly sea-shore or mountain reservations, where the majority of the people enjoying these recreation facilities come by railroad. But the railroad almost always exists primarily for other purposes of state or nation-wide scope and its location has to be determined primarily by these purposes and by topographical considerations. About all that can be said then in this regard is that the railroads can hardly be expected as a rule to modify their lines much for the sake of local parks, and that therefore the local parks must be located and designed so as to get as much good and as little harm from the railroads as possible.

"Transportation by water, however, is a friendly thing to parks in almost every way. The river or pond or the ocean is a pleasant and restful thing to look at and the city which is blessed with the possibility of access to water will certainly go out of its way to locate parks upon it. Traffic over it is restful as well as interesting to watch from the park, and views across it give an effect of expanse like views from hilltops, without the necessity of controlling a large area of land.

"Aerial transportation is likely in the future to bear a close relation to our parks. There is as yet no particular sign that heavy 


\section{LAND PLANNING IN THE UNITED STATES}

freight will be carried by airplane in the near future. This traffic will be to a great extent purely pleasure traffic and the rest of the swift traffic for business will have a large element of pleasure in it particularly as we get used to this means of transportation and as the danger becomes less. The requirement of a large landing and starting field can only be economically met at some point at a considerable distance out from the center of the city. It might well be adjacent to a park or at least linked to other pleasure transportation and to the heart of the city by being situated on the parkway and boulevard system. It is not desirable to use a large open lawn in a park as a landing field and to expect it to retain its essential function as a part of a park. However interesting it may be to watch the arrival and departure of airplanes, it can hardly be considered restful, nor as yet even safe, and the necessary hangars and other provisions for the airplane traffic would be largely destructive of the effect of any naturalistic landscape unit."

Playgrounds.-The relation of playgrounds to parks is a much-discussed question. It is obvious that intensive play and use of play apparatus will successfully discourage green grass. For games considerable open space between trees is necessary. The fact is, though it is not always recognized, that intensive playgrounds and green parks cannot exist on the same space at the same time. As to placing playgrounds in parks it is the quite general opinion of landscape architects that schools and playgrounds serve their best purpose when located in the center of a community of homes. But if, for some special reason, it is desirable or necessary to place a playground in a park, it is an axiom that the playground should be separated as completely as possible by planting and design from the park, for "landscape parks are properly restful places, not helped by noisy neighbors," "a playground is not a park, and no part of an existing park should be set aside for a playground-or run as a playground without any specific setting aside-without a fair facing of the fact that thereby the area and efficiency of the park as a park are by just so much diminished."

There can be no nice balancing of the comparative importance of parks and playgrounds. Supervised playgrounds 


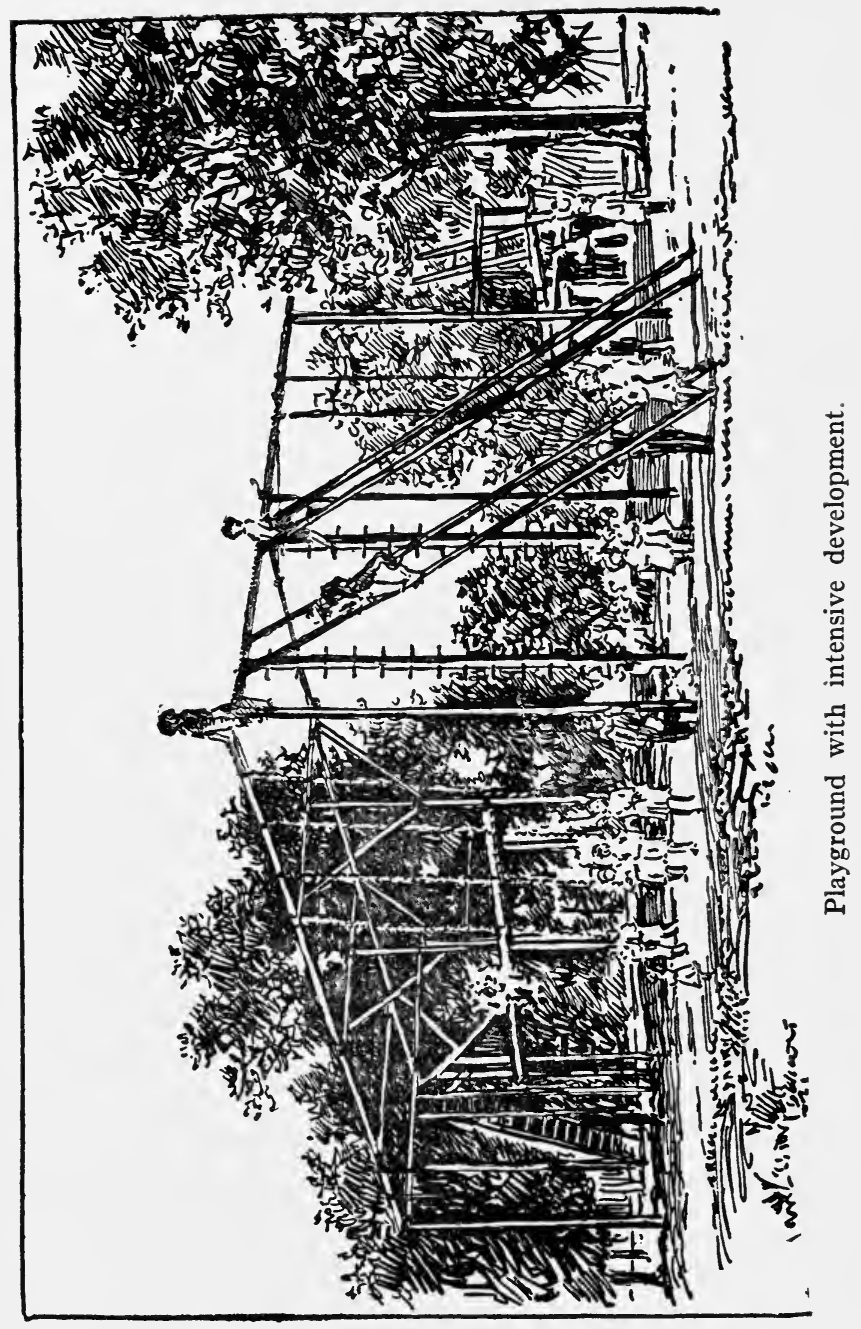


are accepted in our stage of civilization to be as necessary as public schools. Indeed their size and distribution in any city plan should be studied in close connection with the size and distribution of school yards. School grounds and playgrounds should normally be placed in the center of a small community of homes which will keep both comfortably full but not overcrowded. We can count distance to be traveled by the children as one method of finding correct locations but it is obvious that density of population will also influence the size and distribution of schools and play spaces. The present organization of public education into primary schools, junior and senior high schools lends itself to the orderly arrangement of locating schools and playgrounds for children under twelve within a very short radius of their homes. The children over twelve in the junior high schools may travel a little further to their schools and playfields. The high school youth may make considerable trips to school and to sports fields.

In every growing city the locations for schools change from generation to generation. Areas which once were residential become commercial or industrial and schools and playgrounds are no longer needed. New subdivisions are opened up for homes. In these there should always be reserved proper spaces for schools and playgrounds. It has been suggested that 10\% of every subdivision be set aside by law for parks and playgrounds. While this may serve as a sort of rough guide for needed recreation space in the immediate neighborhood, it is obvious that percentage of land to be reserved for parks will bear a varying relation to the number of people using an acre of recreation space.

But it will at once appear that ten per cent of a single block is less useful than ten per cent of a ten or twenty-acre plot. When homes are erected by single houses, by twos and threes, by blocks and by many small units, it will be seen that provisions for neighborhood conveniences, including schools, playgrounds and parks, must be in the hands of some general authority. The City Plan Commission in many cities renders 


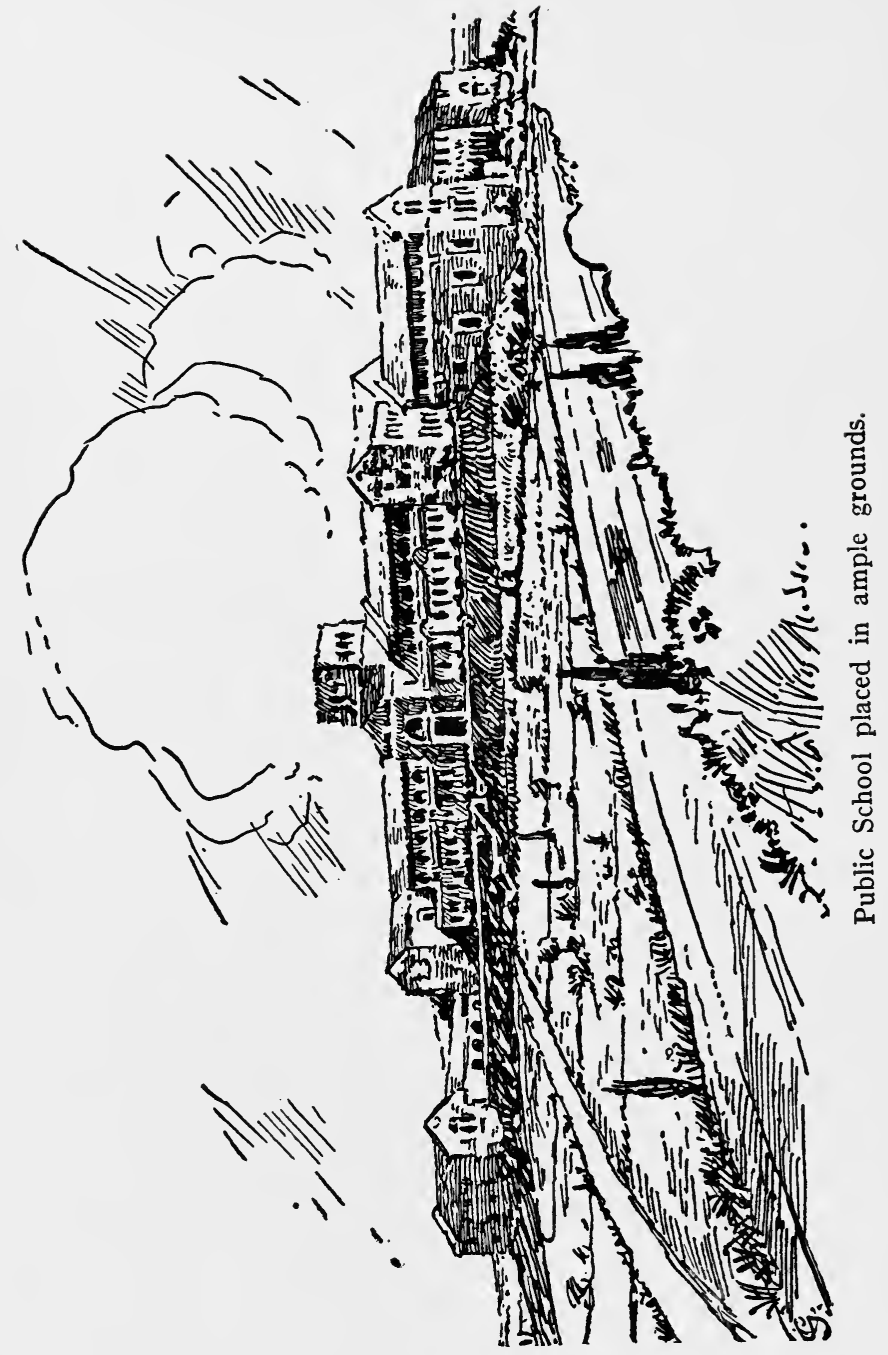


exactly this service to the citizens of the newly-developed suburban sections. It is impossible to develop the plots of all the different owners as units. But the neighborhood must be developed as a unit if it is to offer the facilities which our American citizens have come to demand. The alternative in the helter-skelter building without plan is that the land is often covered with homes housing a large population and no adequate areas are available for school and play purposes. Then inadequate school and play facilities are provided in locations which are far from convenient, often at greater expense to the tax payers than would have been the case if the City Planning Commission had been in existence and had exercised its proper function of making sure that proper reservations of land for school and recreation were made to serve the neighborhood.

This same ten per cent has sometimes been suggested as a gauge of park space to be reserved in the entire city. When Hartford and Baltimore had approximately ten per cent of their area in parks there was one acre of park for every $8 \mathrm{I}$ citizens of Hartford and one acre of park for every 253 citizens of Baltimore. A few years ago Baltimore extended its city limits to include a very much larger area without adding park space in anything like the same proportion. The figures after the new city limits had been adopted would tell a very different story though the situation in the old city had hardly changed.

Parks and the City Plan.- It will be seen that the selection of adequate park areas properly distributed can only be made intelligently when the entire city plan is being considered. If the parks are well selected, and even when they fall short of the best arrangement in size and location, they should be maintained as parks and not as sites for public buildings. Mr. Harold A. Caparn, Chairman of Parks for the American Civic Association, was right when he said:

"Parks serve the public by preserving open spaces. Land dedicated to park uses should not be made the site of buildings which do not serve park purposes in the mistaken idea that an economy is 
effected. Such encroachments upon park areas are wrong in principle and likely to prove exceedingly expensive."

Professor Hubbard has been more emphatic:

"As to the placing of buildings like libraries, court houses, city halls, museums, and so on in public parks, to say nothing of less useful and less public buildings, the defender of park values often wishes he could paraphrase the famous chapter on snakes in the history of Ireland, and say-there are no buildings in parks! It is hardly necessary to say here that a park is not a piece of waste land-a sort of municipal backyard which is improved by any reputable use made of it,- - but on the contrary an essential part in the city's possessions designed for its definite purpose, and not to be intruded upon by facilities for other purposes, no matter how important these may be in themselves. When we say 'parks' in this connection, we mean parks properly so-called. We are not protesting against monumental and architectural squares and plazas, nor do we object to the city ball standing in 'city hall park,' if in reality the area is and should be merely an ample setting for a public building."

As a matter of fact the parks of most cities are supplemented by the grounds around various sorts of public buildings. In Washington the very extensive grounds of the Soldiers' Home are used for recreation of the families living in the vicinity. Indeed the rather cramped grounds of Columbia University in New York serve as a shady shelter for mothers, nurses and children during the summer months.

Park Uses.-During the last quarter of a century we have discovered a good many new park uses. The time was when the boys played baseball in vacant lots. Their sedate elders and the little girls sat on benches in the parks. Perhaps the little girls rolled hoops down the paths. To-day modern park systems provide golf links, tennis courts, baseball diamonds, football fields, outdoor municipal theatres, elaborately equipped picnic grounds and many other facilities for outdoor enjoyment.

The small parks of Chicago, particularly on the South and West sides, have developed many interesting uses adapted to the special needs of the neighborhoods.

Needless to say these neighborhood parks, these community 
centers, supplied with club houses, club rooms, club libraries and all modern conveniences, are not, and do not pretend to be, country parks, but they form an important part of any well-balanced park system in crowded metropolitan areas. The daily park habit is built up by constant use. No doubt some of the millions who visited Chicago's municipal forests were induced to do so by the frequent use of the neighborhood park. Moreover such community centers as have been developed in Chicago furnish winter as well as summer facilities.

If we may take for granted that the case for parks of all kinds has been proven we should now inquire as to how they shall be paid for and who shall do the paying. If an entire city-wide plan for parks which shall serve every part of the city is drawn there is every reason to charge the bill to the entire city. If areas are secured ahead of settlement, as they should be, there is every reason to charge part of the bill at least to posterity by providing for the purchase price through the sale of bonds. In platting new subdivisions it is customary to charge the park reservations against the neighboring property on the theory that residence lots are benefited by such parks. In many cases the city planning consultants of Plan Commissions are able to show subdividers how they may plat their land around park reservations in a way to sell the net total number of lots for a larger sum than if there were no parks included. In such cases it is obviously proper to charge the bill to the house lots benefited.

But a sharp distinction should be made between large country parks which should usually be paid for from general taxes, and small neighborhood parks which may, with propriety, be made a charge on the benefited property. Moreover, it might well be that an extensive playground, much needed in a crowded district, would not add to the value of surrounding property. The cost of such a playground should be from the general taxes.

Land Values and Parks.-Indeed, it may be remarked that while the city's treasury is supplied with the increased 
taxes from the increased values of the private property which result from benefits to the individual property owner, it must not be imagined that all parks, of all sizes, established at any time, will so increase the value of abutting property that the cost can be covered. Sometimes the excessive cost of parks and play spaces must be charged to experience. Seward Park in New York City cost the city between two and three millions of dollars for four small blocks. When the Fens Park was purchased in Boston the cost in the early eighties was ten cents a square foot or about $\$ 4300$ an acre. Land adjoining, needed in 1908, twenty-six years later, was estimated at something over $\$ 2$ a square foot, or over $\$ 86,000$ an acre. If purchased in 1908, or to-day, it might well be that land acquired for park purposes would not appreciably enhance the value of abutting property, yet from a city-wide standpoint the purchase of additional park land might be abundantly justified. As in many other economic affairs of life there is a right period for purchase when the proposed park areas may be acquired at a minimum of cost and at a minimum of carrying charges (always considering the loss in taxes from publicly owned property), until the time when the land will be used. If the psychological period has been allowed to pass there are many instances in which the land should be acquired at any money cost in order to avoid other evils which fall heavily on human beings deprived of the opportunity for enjoying sunshine and fresh air. But when a naturally scenic area bordering a stream or lake is threatened with destruction it is safe to say that the last call has been issued for its maximum use for park land. When the trees have been cut and the land has been built upon for all practical purposes the area has been lost to the park system.

There is only one way in which an adequate park system can be built up and that is through proper planning ahead, with areas selected by specialists trained in landscape design and city planning, followed by the designation of some authority responsible for acquiring at the right time every recom- 
mended park and parkway. A park system is not built in a day or a year. It should be planned at least fifty years ahead and even then it will be necessary to provide for a periodic stock-taking to push out the limits into the country and to take care of overcongested districts in town. Neither can a park system be built by patching together chance bits of acreage which may be offered to the city as gifts or which may be purchased at the insistence of some interested property owner or agent. There is some flexibility, of course, in the recommendations of city planners. Perhaps all the suitable park areas, so far as topography is concerned, are not needed. If so the fact that there are alternative park locations is a factor in making the purchase easy.

Purchase of Parks. - There is a great deal of complaint on the part of Park Commissioners that owners put up the price as soon as they know their land is indispensable to a park system. Even under condemnation proceedings it is necessary to arrive at a fair appraisal of value. No doubt there will always be some bargaining in the sale and purchase of land; but the method of scientific appraisal will come into commoner use. It will be less difficult to secure the services of trained appraisers and the appraisals, based on easily calculable conditions, will tend to reflect fair economic values, so that the fear, so frequently expressed, that the designation of proposed parks on city plans makes it necessary to pay a larger price, will hardly be justified.

\section{SUGGESTED READING}

Henry V. HubBard, "Parks and Playgrounds, their Requirements and Distribution as Elements in the City Plan," in Landscape Architecture, July, 1922.

"What Everybody Should Know About Parks," in the American Civic Association's Park Primer.

J. HoraCe MCFardand, chapter on "General Recreation Facilities," in City Planning, edited by John Nolen.

JoHn Nolen, Chapter on "Park Systems," in City Planning. National Municipal League Series, 1916. 
Oumsted Brothers, Report to the Park Board of Portland, Oregon, quoted in City Planning, edited by John Nolen.

Harvey C. Carbaugh, Editor, Human Welfare Work in Chicago, I9I7. Charles E. Doell, "Methods of Financing Park Projects," in Parks \& Recreation, September-October, I925. Also reprinted.

\section{NOTES}

\section{Page 207:}

Dr. J. Horace McFarland has described the service performed by the small parks on the South side of Chicago.

"Right in the heart of these industrial districts, competing with hundreds of saloons (this was before the Volstead Amendment) dance-halls and worse, are these city-provided spots of green, these 'country clubs,' as I might call them, of the people. In one instance fifty-seven houses were demolished to make place for the community center-a telling commentary on the expense of hindsight as compared with foresight in city planning. These Chicago centers average no less than ten acres each; they provide intimately for the recreational needs of the nearby population; they are not set forth as charities, but as proprieties, if I may so strain a word. And they are used by the people as a right, with self-respect; for they are provided by the city, all the city, for the city, all the city. Said the superintendent of the center nearest the great, grim, and bustling stock-yards to me one very hot July Sunday when I was seeing how Chicago cared for at least some of her people: 'Yesterday after the quitting whistles blew, there came from the stock-yards to this center the regular throng, and 2763 men used our shower baths!' Then I saw how this provision extended to all the recreational and, indeed, the social needs of the family, from the baby playing happily in the sand-boxes to the young women having a party of their own in one of the assigned rooms of the impressive building that was an example of and for civic pride and provision. Folk dances were competing outdoors with a ball game; the refectory was selling ice cream-of a quality unexcelled anywhere-at a nickel a portion, with milk, cakes and rolls at as near cost as they could be figured; boys and girls who were not in their own outdoor gymnasium were contentedly reading in their own library, under the eye of a child-loving librarian. But the best of all, to me, was the hustle and scramble of other boys, a hundred at a time, as they got in line for a sterilized suit and towel preparatory to an hour in the great open-air swimming pool, as beautiful as any Roman bath of old.

"Orderly? Yes, and without blue-coated restraint. For all were gentlemen and ladies using their own club, if you please, even though most of them would not have comfortably pronounced the name of the center in English!

"Here then was the competition of the city with the forces of evil, not only for bodies but for souls, for citizenship, for working efficiency, for Monday-morning-on-the-job; here was Chicago's answer to the question as to being her brother's keeper: here was the 


\section{I 2 LAND PLANNING IN THE UNITED STATES}

shrewdest economy of city government! Is it any wonder that within a half-mile radius of these wonderful centers juvenile crime in I9Io, decreased 44 per cent, while outside that radius it increased II per cent ?" 


\section{CHAPTER XII}

\section{BLOCKS AND LOTS}

Streets serve two important uses. They are mainly, of course, channels of traffic, usually carrying distribution of utilities underground. But the size and shapes of the plots of land left between the streets is a most important factor in city planning. In the early colonial days land was plentiful and cheap and large deep blocks seemed useful in residence neighborhoods. In downtown districts waste land back of the buildings fronting on the street seem unimportant. The blocks of Manhattan, as laid out in the plan of I8II, were 200 feet by 650 to 920 feet, laid out with no alleys, commonly with eight lots 25 feet by 100 feet facing on the main north and south avenues and with a row of intervening lots of the same size fronting on the east and west cross streets. This made four of the lots what is called "key" lots, that is, one side of each of these four lots adjoined the backs of the four lots facing on the north and south avenues. There were variations of this arrangement. In any case there was no access to the rear of the lots except from the street frontage.

In Philadelphia a large part of the city contains blocks 396 feet by 400 feet in size surrounded by streets fifty and sixty feet wide. When the old mansions set in these spacious blocks gave way to smaller houses some of these blocks have been replatted with two narrower residence streets between the main streets in a manner to give 168 building plots or 46 dwellings to the acre. The lots vary from 14 to 16 feet in width and from 49 to 60 feet in depth. A three-foot passage gives access to the rear. The lots are then covered with houses to the extent allowed by the law which means that the entire 


\section{I4 LAND PLANNING IN THE UNITED STATES}

lot is covered with the exception of a strip about ten feet deep at the back, leaving a space between the rear building lines of twenty-three feet, including the three-foot rear passageway. Neither the original block nor the "three-in-one" into which it was transformed seems particularly well suited to platting into building lots for residence purposes.

In Chicago blocks I 70 feet by 594 feet are cut in two by a fourteen foot alley leaving 36 lots 25 feet by 125 feet and twelve lots 24 feet by I 25 feet. In this case the houses front in two directions only and there are no key lots. There is also access to the rear from an alley.

With all these and more variations in shape and size the rectangular block is the result of the checkerboard plan of survey by which we measure and describe land in the United States. But standardized blocks, regardless of whether they are to be used for factories, commercial buildings, apartment houses, row houses or single-family dwellings, and with no relation to the size or type of these structures, are quite as awkward as standardized streets. Just as we believe that streets should be designed for the special purposes which they are to serve we now realize that blocks need not all be the same size and that, indeed, there is every reason that different parts of towns should be supplied with different units. Often the topography suggests informal methods of platting residence neighborhoods. If lots must be small for economy's sake the tendency is to make them somewhat broader and a little shallower than in the older rectangular blocks.

Apartment houses can make good use of substantial areas and in many of the larger cities they are built around an extensive inner court with gardens which really make the street frontage the least desirable of any. Small shallow lots in small blocks would not lend themselves to this treatment.

Commercial buildings in such cities as Chicago often use very large floor areas. Even when they are permitted to soar into the sky there are certain advantages in connected floor areas. Many Chicago buildings are connected by passageways 
across alleys and even across streets. The small lot and the small block are not suited to buildings which need large floor areas.

In industrial areas there is usually a demand for blocks of land covering several, or occasionally many, blocks. These areas can often be arranged in the city plan so that they need not block the traffic of the city; but such industrial areas divided into units larger than in other parts of the city should never be placed across the line of traffic between two important parts of the city or across the main thoroughfares which lead to adjacent cities and towns.

In a modern city there should be no standard ready-made blocks and lots. The topography, the natural features of water fronts, existing forests, prevailing winds and many other conditions should be studied. A general allotment of space to industry, heavy and light, to commercial buildings in downtown sections and along main thoroughfares for neighborhood patronage, to various types of residences, to recreation spaces, to public buildings and other uses should be blocked out roughly in advance. In the case of existing cities these can often be adapted from the city as it is. Once these important fundamentals are settled and the arterial street system with its main traffic connections determined, the streets and blocks with their lot units can be designed in each section to fit the topography and the use to which the land will be put. In growing cities some sections must be made interchangeable. Residence neighborhoods of yesterday are commercial areas of to-day. Residence neighborhoods of to-day may be commercial or even industrial to-morrow.

In Washington many of the larger blocks have been developed in hollow squares around alleys which are lined with buildings. These buildings are the alley homes of some eight thousand of the population. In other blocks the interior buildings are used for garages and other purposes. No better example of the unfortunate use of large blocks could be found than in these Washington blocks cut by a tortuous network 


\section{I 6 LAND PLANNING IN THE UNITED STATES}

of alleys and filled with buildings removed from the publicity of the streets. In Baltimore, though perhaps in lesser degree, many blocks in the old section have been subject to the same kind of treatment.

It will readily be seen that in the platting of streets, blocks and lots, a simple book of instructions cannot be prepared to put in the hands of laymen so that each may plat his own land. This is a technical engineering and city planning problem. In view of the fact that streets and blocks, once platted, last almost as long as the civilization which created them, it does not seem an extravagance to require that such platting should be placed in the hands of those who by training and experience know how to do it. 


\section{BUILDINGS}

Public Buildings are more easily brought under public control than private buildings. The American people have taken a good deal of pride in their public buildings. When the taste of the people appeared to be in eclipse it is not surprising that the type of public buildings erected was at a low level. But the education which the American people have received from travel and books is having its effect on their judgment and is giving them a nicer discrimination in architecture and art.

The right of the public to exercise control over designs for public buildings is hardly to be questioned. The wisdom of placing the responsibility for passing on plans for public buildings in the hands of a board or commission trained in architecture has not been so readily recognized. But the creation of Art Commissions and Art Juries in many of our cities and a few of our States has led to the elimination of many atrocities which might otherwise have been erected as monuments to ignorance and bad taste.

Probably the so-called civic center movement has done more than any other to bring about a harmonious grouping of buildings of good design. This was the very direct outgrowth of the World's Fair which set before the American people a new example of the dignity and beauty which could be achieved by the grouping of buildings tied properly to the landscape. The civic center sets us as an ideal that there shall be a grouping of certain public buildings around an open spacethat there shall be adequate grounds for a proper setting and that the approaches to the imposing public buildings shall be 


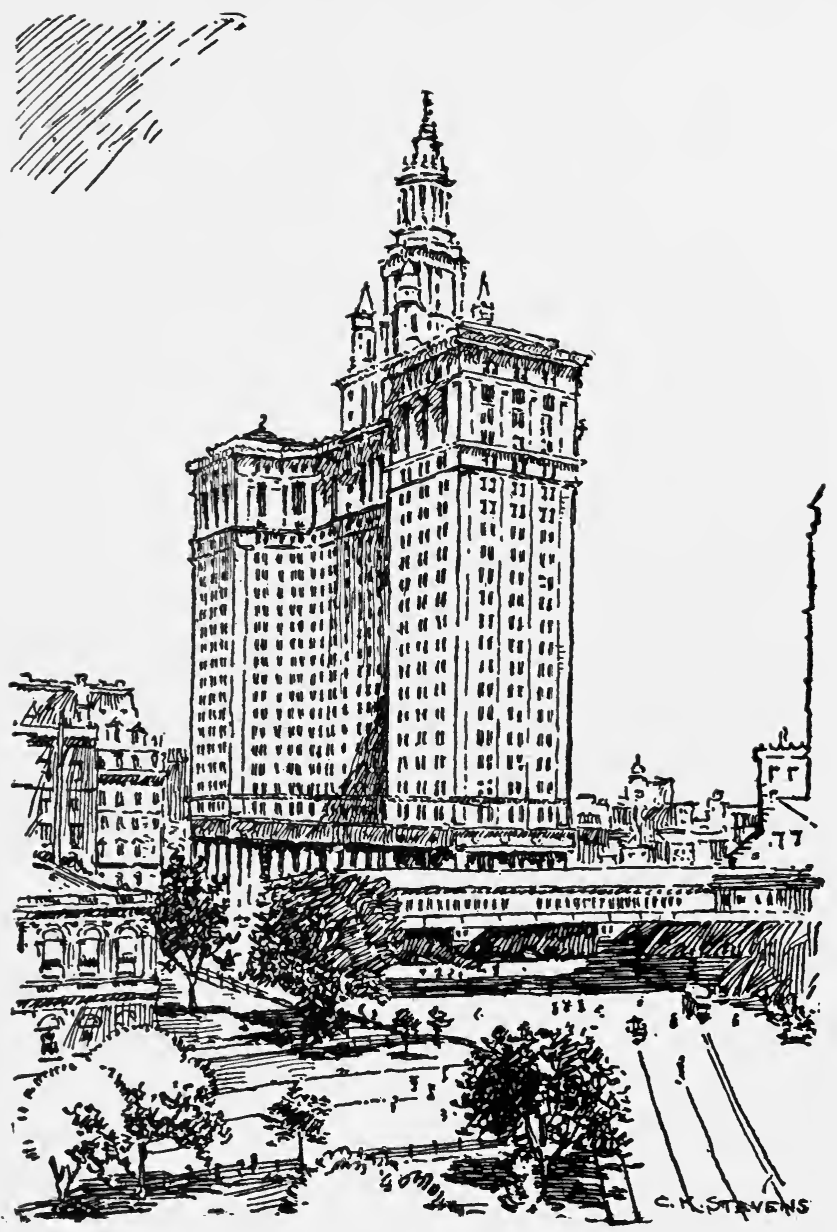

Skyscraper Municipal Building of New York. 
such that the effect is not utterly ruined by the surroundings.

The skyscraper city hall of New York has solved the problem of the small block by spanning Chambers street with archways. It has solved the problem of high land values by extending into the air and on a comparatively small site providing I,250,000 square feet of total floor area, or 725,000 square feet of usable office space for 6000 city employees. Moreover the building is located over an underground railway station. Owing to the peculiar shape of its site there are no courts and every office is a front room with ample outside light. For a part of its length it fronts upon City Hall Park. But in spite of the great beauty and excessive utility of the City Hall, New York has not now, and does not promise, a civic center of proper proportions.

The San Francisco Civic Center, while it might have been more impressive if it had been developed, as was suggested, on the crest of one of the hills in the burned district of 1906, has been planned and partly carried to completion around the site of the old city hall, on comparatively level land. The center includes the city hall, an auditorium, the Library, the State Building grouped around an open park, with the Fire and Police Department, the Health Department, a power building and another public building cornering on the park.

In Denver a very interesting arrangement of open spaces and public buildings has been developed in the area adjoining the State Capitol which crowns a moderately high hill. The city of Cleveland is planning a very ambitious civic center. Springfield, Mass., is developing a picturesque civic center. In fact civic centers have become so popular in the United States that they have taken on the proportions of a "fad." But, while a civic center is, of course, a very small part of city planning, it may, and often has done so, serve as an introduction to the whole subject. Since a well-planned civic center is desirable in itself and since it frequently leads to better and broader planning there seems to be no good reason 
to condemn the movement even when it is undertaken lightly and without real comprehension of the complicated and farreaching planning which may result from so small a beginning. The arrangement of the public buildings in Washington is

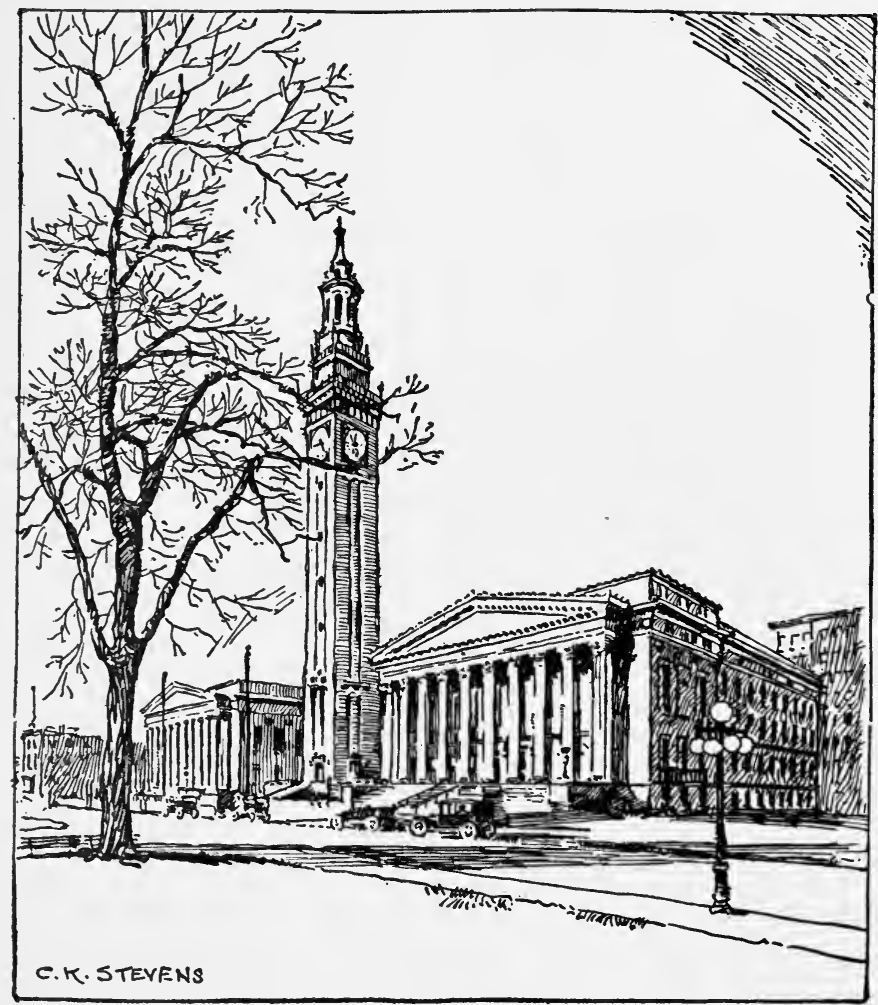

Civic Center-Springfield, Mass.

due to the original L'Enfant plan, though in many instances the plan has not been followed, almost invariably to the detriment of the city. But the number and character of the public buildings in the Nation's capital and the extent of the area over which they are scattered renders the designation civic center somewhat inadequate. Rather, the whole city seems 



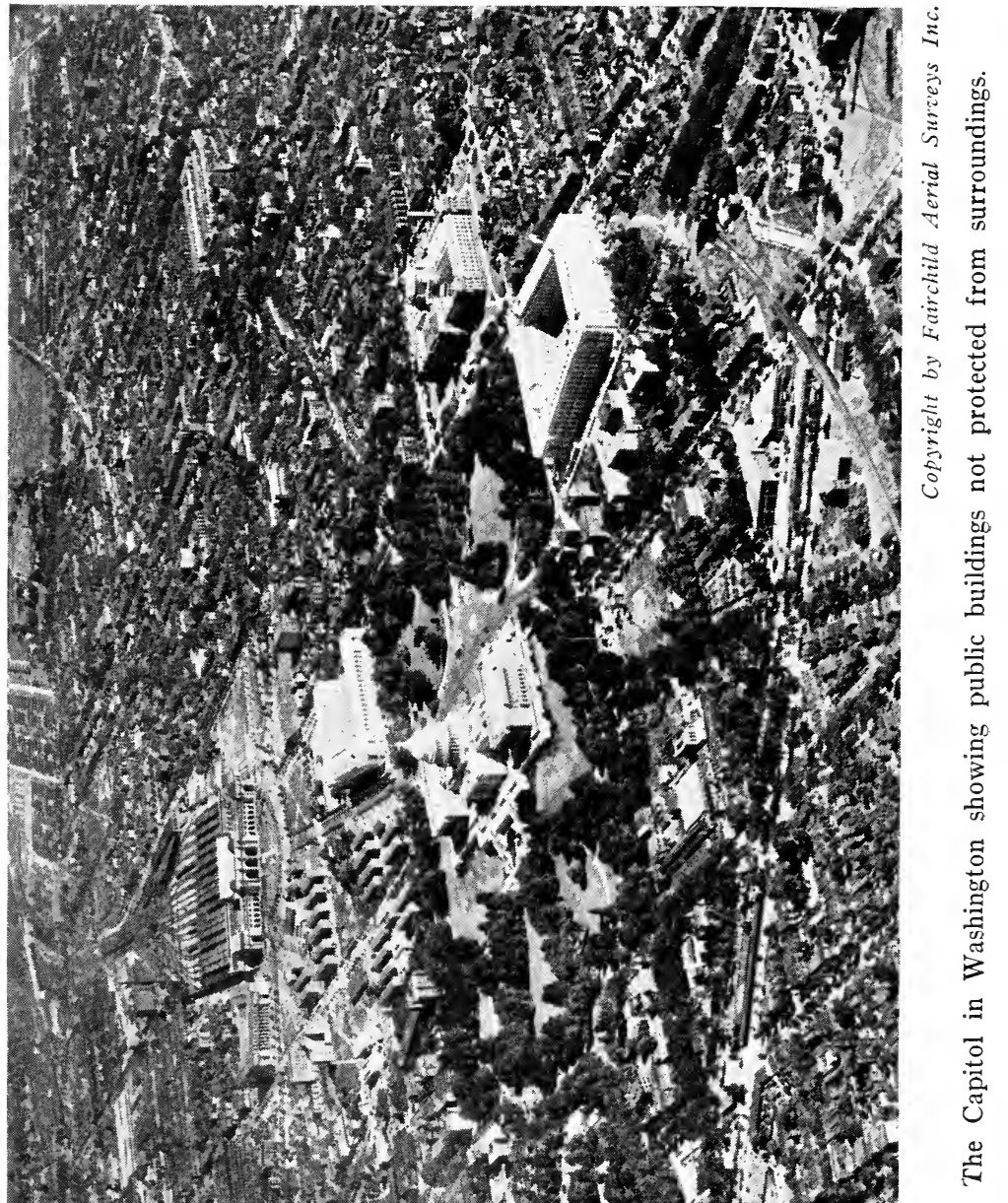


to be arranged around the Capitol group and the White House group joined by the broad mall along which ${ }_{z}$ it is hoped, there will some day be placed a double row of public buildings. Only one public building of those which were to face the three sides of Lafayette Square has been erected-the Treasury Annex. Several tall buildings in private ownership have been erected in recent years which will make the acquisition of the areas much more expensive than if they had been acquired without their improvements. As for the surroundings to the Capitol, no adequate control has been established.

The Park Commission of $\mathrm{I} 90 \mathrm{I}$ and later the Commission of Fine Arts have rendered an invaluable service through the clearance of the Mall from the railway tracks and the location of the present magnificent Union Station. The proper location of the New National Museum and the wings of the building to house the Department of Agriculture, facing on the adjusted axis of the Mall, was due to the efforts of those who supported the recommendations of the Park Commission and the more recent reports of the Commission on Fine Arts. The building of the Lincoln Memorial on the new axis has tended to make the future of the Mall safe from further encroachments. The existence of the National Commission of Fine Arts to which must be submitted all plans for public monuments and buildings, insures, at least, the opinion of trained artists, architects and landscape architects. Guided by the recommendations of experts, public opinion will no doubt see to it that good advice is followed.

In addition to civic centers and the main groupings of public buildings it is often desirable in the larger cities to plan for groupings of minor buildings around a park or set in ample grounds. These minor civic centers can be made quite as effective in their way as the more imposing group around the city hall or the State capitol.

Probably there is less co-ordination shown in the location of the various neighborhood public buildings than in any other planning of public building sites. Schools are frequently 
located without regard to parks, playgrounds, branch libraries, community buildings and other service structures. Not all neighborhood buildings group well together. Schools and libraries supplement each other. Fire and police stations, on the other hand, demand conditions and surroundings quite different from those needed for schools and playgrounds. It is particularly undesirable to locate the fire stations so that the rushing motors, emerging from the building, shall cross the line of children on their way to and from schools.

But there are many semi-public buildings that might well be placed near schools and libraries. Churches, clubs and community buildings in general can be grouped appropriately.

Private Buildings. - The design and construction of private buildings are not so generally controlled though some progress has been made in recent years along this line. First came the building codes which were drawn up under the police power to insure safety in construction. No building should be so flimsy that it would fall down. But each municipality and each small town made its own regulations. Sometimes the building codes were lax. Often they required unnecessary expense because they prescribed materials once in common use but later replaced in part by more modern inventions. Heavy timbering and brickwork were once cheap. Modern engineering provides methods of construction quite as safe which are not dependent on heavy foundation and wall construction. Through the stimulus of the Division of Building and Housing, established in the Department of Commerce, a committee has been working for some time on a model building code which will provide adequate control and still not involve unnecessary expense.

Modern plumbing has brought other problems which must be solved in the interest of the public. The Division of Building and Housing in $\mathrm{I}_{924}$ issued "Recommended Minimum Requirements for Plumbing in Dwellings and Similar Buildings," which will undoubtedly exercise a potent influence on municipalities in the adoption of their plumbing codes. 



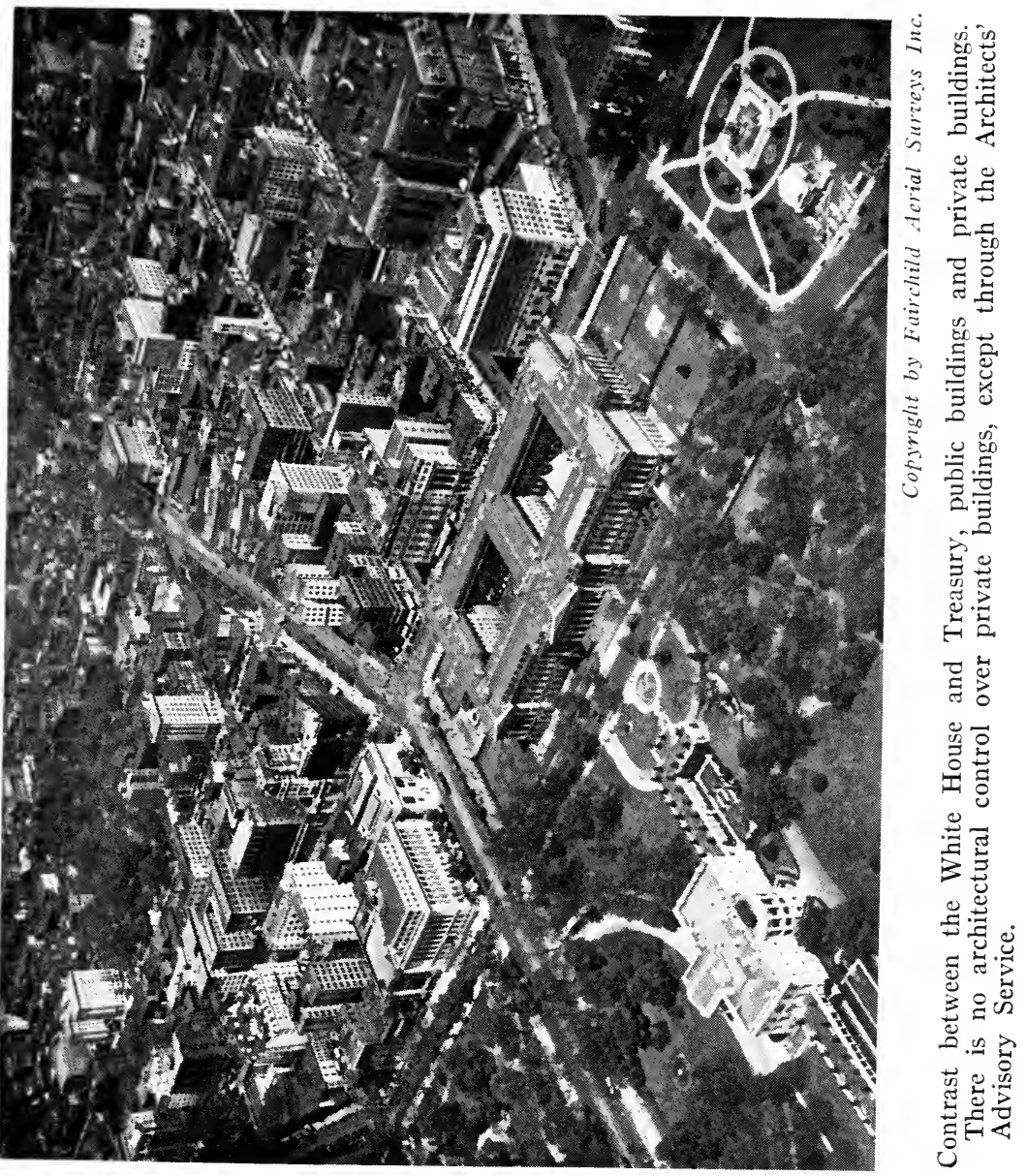


The movement for housing reform has resulted in the adoption of housing codes in many of our cities which maintain a certain minimum standard for air, light, ventilation, open space in lots and provision of adequate kitchen and bath-room plumbing.

With the advent of zoning came a further control of private property, including bulk of buildings, use to which they might be put in specified districts, and percentage of lot which might be covered in the different zones, or districts.

But none of these regulations established any control over the appearance of private buildings. In private subdivisions, such as Roland Park, Maryland, and the Country Club District of Kansas City, plans for residences must be approved by the company architect and home-owners came to consider this "restriction" as an asset because it prevented the intrusion of some monstrosity which would offend their eyes and decrease the value of their property. The standard of architecture in such subdivisions is very high and the general appearance of the community is greatly enhanced by control of the design of the houses.

Sometimes official art commissions are asked to give advice concerning the design of private buildings, but up to this time no adequate control of the design of private buildings, either commercial, industrial or residential, has been set up. Conceivably a commission composed, as is the National Commission of Fine Arts, of artists, sculptors, architects and landscape architects, with the possible addition of an engineer, might be authorized to approve designs for private buildings.

In Washington a group of local architects has originated an Architects' Advisory Service which is entirely voluntary and given as a public service. These architects give of their time in relays to go over plans submitted to the officials and to make suggestions which may, or may not, be acted upon by the owners.

While it may not be said definitely at this time just what form the public control of private buildings in regard to ap- 
pearance and design will take, it is safe to say that these recent developments foreshadow some kind of control, to be exercised in the interest of the community as a whole. When an owner erects a building on his lot which reduces the value of his neighbor's property we have tangible evidence on which to move. As the American people become better educated and more discriminating concerning architecture, the erection of poor types of buildings will have just that result and we may confidently expect when that day comes that the public will set up some kind of machinery to deal with it. The extension of the powers and personnel of Art Commissions might conceivably serve the purpose. Or, perhaps, architects' councils will be set up. It matters not how it is done. The need is apparent. We ought to accomplish in the improvement of private buildings something of the same advance that we have made in public buildings.

Skyscrapers.-Perhaps the type of private building which has attracted the greatest discussion and the most wide-spread legislation through zoning and otherwise is the skyscraper. Like many modern developments in individual enterprise, the skyscraper owes its picturesqueness and most of its light and air to the fact that it towers above its neighbors. When neighboring property is covered with similar skyscrapers, the picturesque isolation is lost and the lower stories resemble basements and sub-basements. But the skyscraper when multiplied indefinitely not only brings problems of health and comfort, it develops acute economic complications.

Mr. Frederic A. Delano, in an article on "Skyscrapers," in the American City for January, 1926, describes the process of pyramiding values:

"An owner finds that the market value of his lot has risen to a high point where his existing building (perhaps five stories high) yields but a poor return on the ground rental or the assessed value. He calculates that if he puts up a building fifteen or twenty, or thirty stories in height, he will have more leasable space from which to collect the ground rent or taxes. By any one of several means he finances the construction, with the expected results. The immedi- 



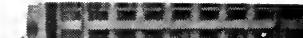

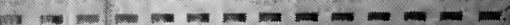

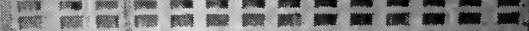

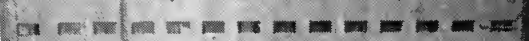
Wy

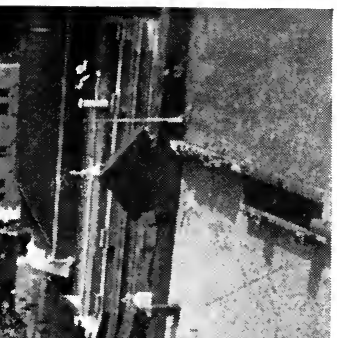

$\underset{\nabla}{\square}$

$\underset{5}{2}$

논

อุ.

넌

$\stackrel{0}{\Xi}$
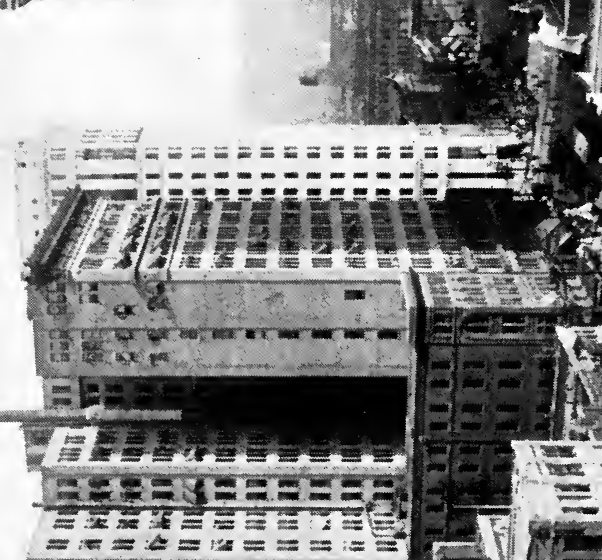

$=2, \cos 2$
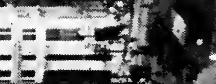

-

일

密

롫

$<$

()

के II

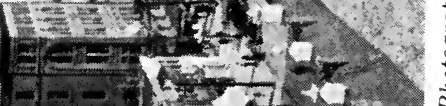

ช

द्

ก $\frac{\pi}{4}$

4

हี

迅

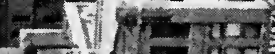

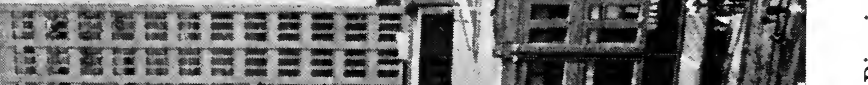

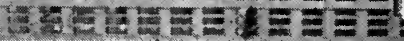

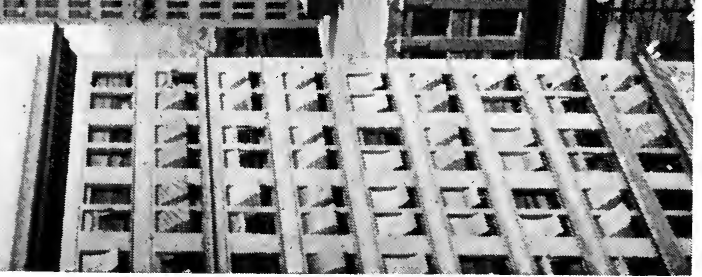


ate effect of this is to increase the potential and, therefore, market and taxable value of near-by property, and at once other property owners in the neighborhood are more or less forced to build into the air or find that their lots are being taxed more than they earn. In the end the first man's building no longer enjoys its early advantages in the way of light and air, and the streets of the neighborhood have become dark and congested. In some cases the impelling motive appears to be publicity, rather than profit on the building itself. . . .

"When a number of owners put up high buildings to cover their taxes, the following results must be expected, except where the city is growing extremely fast:

"(a) the increased supply of office space will reduce rentals for the owners of all the buildings, and accordingly reduce or wipe out their profits; or else, (b) the new skyscraper district will kill values in outlying office districts, resulting in zones of deteriorating value and obsolescent construction. Such zones have unfortunate indirect consequences. In New York, for instance, they are the homes of the sweated trades and of the industries which could not survive in the center if they had to pay real rents. In other words these areas of deteriorating values delay the dispersal of small industries into the suburbs and satellite towns and become a new cause of congestion."

New York is finding what it means to pay the costs for the burden on the community of the extensive skyscrapers which line streets all too narrow to carry the traffic or to provide sufficient light and air.

"If a man erects an office building which houses ten thousand people on an acre of land, it is obvious that he has thrown upon the community a burden which every one must help pay for."

"When it is remembered that a high building, whether it be an office building, a hotel, an apartment house, or a department store, brings in its train not only a large population which must be cared for and transported, but also at once brings a demand for accommodations for loading, unloading, and storing (parking) motor cars, taxicabs, vans and so forth, we begin to see that the cubage of buildings must have a definite relation to the number and the width of the public streets. The zoning of street frontage for particular uses must go hand in hand with regulation of traffic in the streets, and must be done under the police power fairly, and so as not to let anyone for a price do something that is in effect detrimental to the neighborhood. 


\section{LAND PLANNING IN THE UNITED STATES}

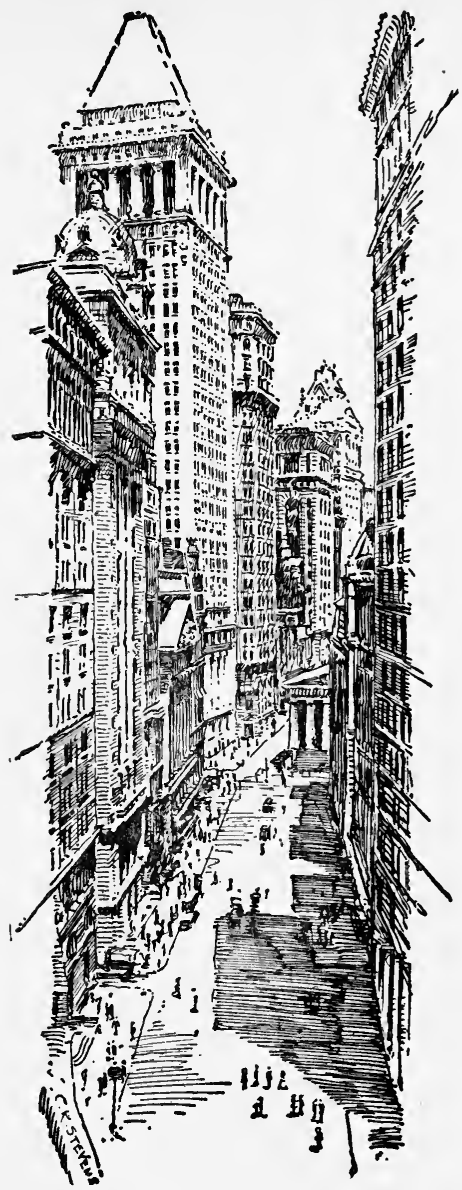

"Broad" Street, now too narrow to serve the day population of the tall buildings.

Mr. Delano's conclusions are so well analyzed that they are quoted:

"On the face of it, it would seem:

"First, that every city must plan for some fixed basis of maximum 
of population per acre that will be cared for in each of its several zones.

"Second, it must determine what average height of buildings will be necessary to maintain such a population without interference with the interests of the community at large. Having made this determination, it should let property owners be free to build substantially as they wish on their own property, provided only that this average is maintained.

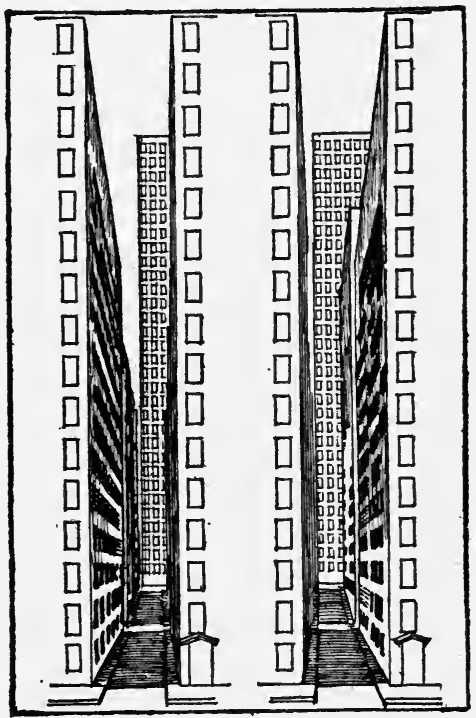

In rooms with black windows tenants were using artificial light at noon on a bright sunny day.

For example, if five stories were the normal limit, the property owner who wished to put up a ten-story building, would be privileged to occupy only one-half of his lot, or make corresponding setbacks giving the same net results. If he wished to erect a twentystory building, he could occupy only one-fourth of his lot, and so on. If, instead of this sort of limitation, a city prefers to allow high buildings to be built regardless of such an average requirement, it must, by means of zoning for use, coupled with taxation, place a tax burden on the high buildings, which shall be in some way commensurate with the burden that is thrown upon the entire community. 


\section{SUGGESTED READING}

Arnold Brunner, "The Civic Center," a Paper read before the American Civic Association, reprinted from the National Municipal Review, January, I923, vol. XII, No. I.

Standards Recommended for Permanent Industrial Housing Developments, in the Report of the United States Housing Corporation, vol. II, Government Printing Office, Washington, Igrg.

Nelson P. Lewis, The Planning of the Modern City, Chapter VIII, on Public Buildings and Civic Centers.

Frederic A. Delano, President American Civic Association, Chairman Regional Plan of New York and its Environs; "Skyscrapers," American City, January, I926.

Page 2I7:

\section{NOTES}

Mr. Arnold Brunner, discussing the civic center before the American Civic Association a few years ago, said:

"The selection of a site for a civic center depends on local conditions and often there is some spot already accepted as the heart of communal life, but if an entirely new location is sought there are many serious considerations to govern our choice,-its proximity to the center of the population and to the geographical center of the town; its accessibility by broad streets and direct thoroughfares and by trolley lines; its relation to important business sections, its probable effect on them and their growth and on the growth of the city; the possibility of its affording relief of traffic congestion by distributing it or separating it from existing thoroughfares; the visibility of the site from various points, the nature of the environment, its freedom from smoke and dirt; the advantages offered for successful grouping and composition and the elasticity of the plan for future enlargement; the cost of the site and its effect on values of surrounding property by enhancing and stabilizing them. All things being equal it is naturally advisable to select inexpensive ground, not only on account of the initial economy but in order to secure for the city the advantage resulting from the inevitable rise in values of the neighboring ground.

"These are a few of the points to be considered, some practical, some aesthetic. The demands of beauty and utility must yield to each other and combine with each other to obtain the complete harmony which we seek and which is surely attainable.

"This is the basis of the art of city making, the civic renaissance that is transforming our country, a protest against the license and disorder that are to be found everywhere. The civic center is an example of wise control. It represents law and order. Here the streets meet and resolve themselves into regular forms; the buildings stop swearing at each other, they take their places in the civic ranks like true soldiers obedient to authority....

"The cost of changing a railroad switch, the grade of a street 
or moving a fence or a telegraph pole, the expense of everything and the difficulty of altering anything have so clouded the perceptions of 'practical men' that they cannot look forward at all. Their limitation economy has dispelled many visions and schemes for the benefit of mankind, delayed and even nullified the growth of many a city.

"I recall that a number of years ago when a few of us were trying to secure a civic center for New York and endeavoring to find a site for the new court house, we urged the committee in charge of this project to acquire the property on the north side of City Hall Park. You know that New York has always intended to build a new court house, and in political circles selecting a site for it has been considered the king of outdoor sports. I was spokesman of this particular committee and after explaining our ideas, the chairman of the board said to me, 'Young man (you may know by this how long ago it was), do you know how much that property is worth?' Of course I did not know and we retired in confusion. Some years after the same scene was repeated, the only difference being that I was a little older and the chairman of the board was replaced by another practical man, who, when he heard our plea for the only logical site for the court house, repeated his predecessor's question, 'Do you know what this property is worth?' and then I was able to respond triumphantly, 'Yes, sir, exactly twice what it was worth when we suggested its purchase before."

Mr. Brunner made a special plea for the proper setting for civic centers:

"We have the Boston State House dominating the town from its proud eminence, the famous gilded dome visible far out at sea; and that other gilded dome in Hartford in its charming environment. We recall the Albany capitol on the crest of the hill at the head of State Street proudly overlooking the Hudson River and the graceful classic building in Providence also on rising ground, the magnificent capitol of St. Paul, the Des Moines public buildings in their 75 acres of park land, and the symmetrical official group in far-away Olympia in Washington state. These and many others give us varying degrees of pleasure and satisfaction.

"But where is the park around the Boston State House? And why is the view from the river of the Albany capitol obscured by an intrusive commercial building? And what is Providence doing about the railroads now too much in evidence? And when will the approaches to the St. Paul capitol be completed?"

Page 227: Mr. Delano in his article on "Skyscrapers," presents the arguments, pro and con, as follows:

"Arguments in favor:

I. High buildings which, in effect, mean the intensive use of property, are required in order to earn a fair income on high-priced property.

2. High buildings frequently give magnificent views of the surrounding country, and, at the same time, give the tenants the enjoyment of a maximum of light and air. 


\section{LAND PLANNING IN THE UNITED STATES}

3. There is great convenience incident to concentration. Horizontal distance is converted into vertical, making, by reason of the rapidly moving elevator, for greater convenience.

4. A single office building forty stories high on one acre of land is no worse in respect to causing congestion than four office buildings of similar floor area each ten stories high-though this arrangement, of course, requires the further supposition that in case of the fortystory building the other three acres shall remain vacant.

5. It is urged that a uniform height of building, or uniform cornice line, results in an uninteresting effect, that occasional high buildings lend an interest to the skyline and to the general appearance of the city.

On the other hand it must be recognized that the high building has placed a burden on the community which must be met and must be paid for. Taking up each of the contentions in favor of high buildings seriatim, it is urged in opposition that:

I. It is a real question as to whether high values of land compel high buildings, or the reverse. Apparently we have a vicious circle in which one can hardly say which is cause and which is effect.

2. High buildings give fine views only so long as they monopolize sky privileges, and even then only at the expense of others whose views are cut off.

3. Concentration spells congestion. Conceivably it might be convenient to conduct all a city's business under one roof, creating an enormous beehive of industry; but obviously such a plan, while having some merits of convenience, would be highly objectionable from many other points of view. In our larger cities buildings of thirty stories are common, and there are a few of forty and even fifty stories or more.

4. The trouble about permitting a single office building forty stories high, is obviously that one cannot prevent other similar types near-by, and that is why congestion soon results from a single skyscraper. For example, a forty-story building occupying an acre and accumulating conservatively 10,000 persons is served usually by only one important artery of traffic. On the other hand, four ten story buildings, each occupying an acre, would probably be served by more than one traffic route, and in any case would offer greater freedom of access.

5. In answer to the old argument that a uniform height of building or uniform cornice line, is uninteresting, it may be said that, while this is sometimes true, it is certainly no more so than the irregular hodgepodge which we so often see. Compare, for example, the uniform treatment of the frontage of the Place Vendome in Paris with the usual frontage even of high-class buildings in any American city. Some day we shall learn that a reasonable harmony of design in architecture is as important as harmony in music." 


\section{ZONING AND ITS RELATION TO COMPREHEN- SIVE PLANNING}

The erection of tall buildings on narrow streets with the consequent loss of light and air to the occupants, followed by the realization of what would be the ultimate result if the high buildings covered all available space, led to a search for some means of mitigating the inevitable evils of unrestricted construction. The development of steel frames which made possible the fifty-story building came during the years which also produced the automobile. The combination brought about traffic problems which puzzled the officials of many cities and led to the appointment of a number of special commissions charged with the duty of finding some relief. The Report of the Heights of Buildings Commission to the Committee on the Heights, Size and Arrangement of Buildings of the Board of Estimate and Apportionment of the City of New York was the direct forerunner of the Zoning Resolution which was adopted in 1916, and which in the last ten years has been followed by more or less complete zoning regulations in over four hundred cities and towns in the United States, including an aggregate population of more than twenty-seven million people.

Zoning may be said to be the control by organized communities of the use of privately-owned as well as public land in the interest of the general welfare By means of the police power a city may prevent a land-owner from using his property in a way to injure his neighbor's property. The city does not condemn and pay for any such rights of the land-owner which it may take away from him; through the police power it 


\section{LAND PLANNING IN THE UNITED STATES}

restrains a land-owner from putting his property to a use which will destroy value in his neighbor's property, or to a use which, if applied to all land, would result in conditions detrimental to the health; morals or safety of the people occupying the buildings. The right of a group of land owners to be protected in the enjoyment of their property and the maintenance of stable values is held to be more important than the right of a single land owner to put his property to uses which are in interference with the enjoyment of his neighbors in their property or which destroys values in surrounding property.

Use Districts.-Under present practice in Zoning, land owners may be protected from injury through wrong use of neighboring land by a system of use districts or zones. Commonly these use districts are:

Residence, frequently divided into districts for single-family, detached homes, districts permitting row houses (especially in Eastern cities), and districts in which all forms of multi-family buildings are permitted.

Business or Commercial, for offices, shops and stores, often divided into districts for business offices and retail stores and districts for wholesale establishments.

Industrial, sometimes divided into districts for "light industries," not objectionable because of noise, odors, smoke or dust, and "heavy industries."

In illustration it may be said that a glue factory which dispenses disagreeable odors is a nuisance and would be prohibited in a commercial or business district. A "heavy industry," such as a steel works, would not be located near offices and stores. A laundry, which is a "light industry," would not be permitted in a residence district nor even in a section of business and professional offices.

Height Districts.-Land owners may be protected from injury through wrong use of neighboring land by a system of height districts which controls the height of buildings. A land owner may not build a skyscraper on a narrow street in a way to rob those across the street of a reasonable right to light and 



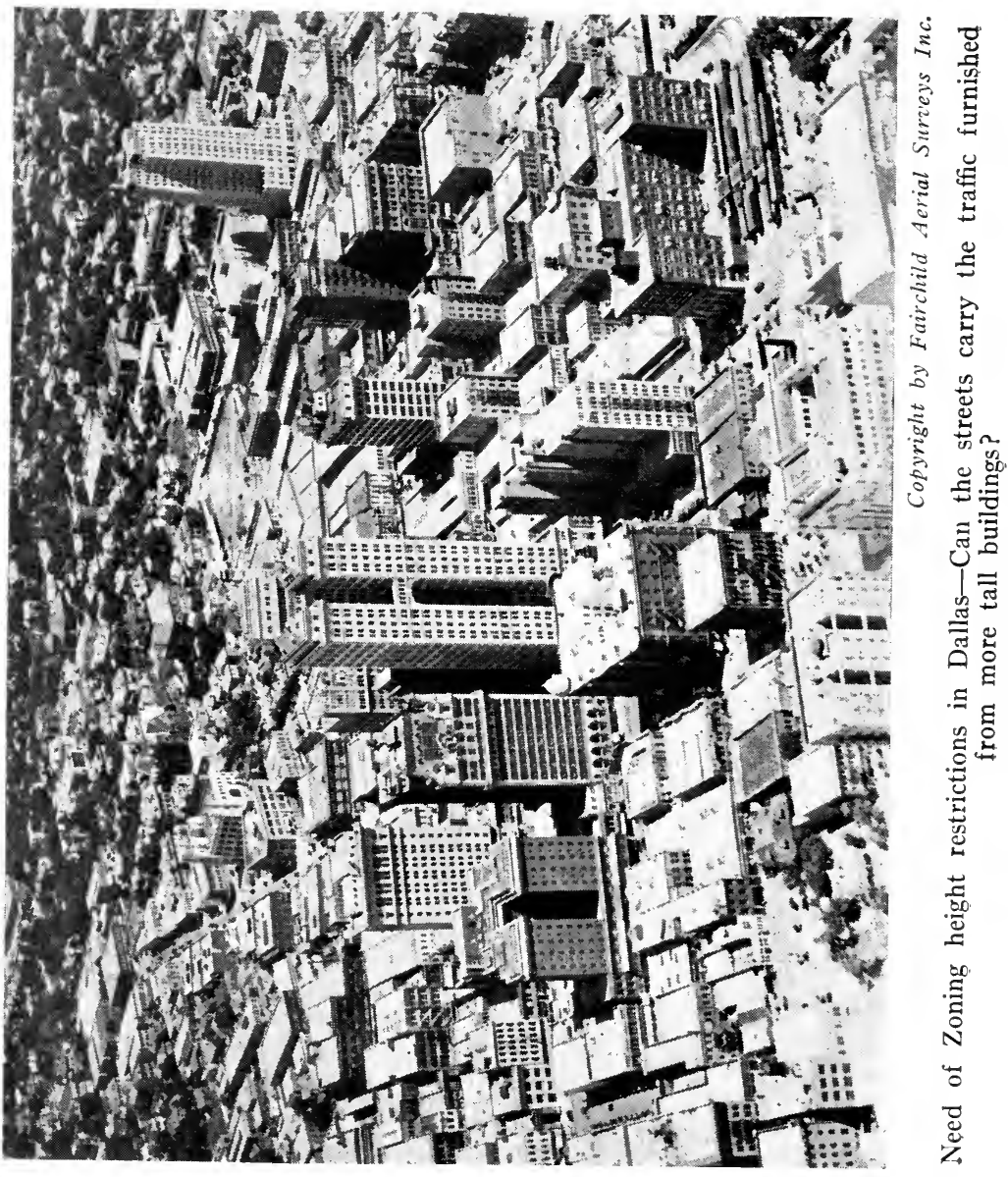




\section{ZONING AND ITS RELATION TO PLANNING 233}

air. Height regulations usually bear some relations to the width of the street. Under proper zoning legislation a land owner may not build a skyscraper which furnishes light and air to his tenants only so long as his neighbors do not exercise a similar right to use their land for the same kind of a building. The principle, put into effect in many cities, which requires successive setbacks in the higher stories is developing a new type of architecture. The skyline of lower New York City is made picturesque by these towering pinnacles.

But important as are light and air to the tenants of a huge office building, the basic principle which led to the limitation of the height of buildings was related to the traffic congestion. There should be a direct relationship between the available street space for foot and wheel traffic and the business population of the buildings on the street. It is a question of scale. If one could conceive a square mile of twenty- and thirty-story buildings with the streets of sufficient width at necessary intervals to provide for a reasonable dispatch of traffic, one could hardly escape the conclusion that more land might well be covered with lower buildings with a better distribution of street space.

Area Districts.-Land owners may be protected from injury through wrong use of neighboring land by a system of area districts which limits the area of lots which may be covered with buildings. A land owner who builds an apartment house or tenement must leave certain spaces and courts uncovered in order to provide light and air for every room. An office building may, under some circumstances, cover the entire lot, at least in the first story, but must be designed to provide reasonable light and air for its tenants. A heavy industry may not only occupy an entire block, but buildings may, under proper regulation, be built over two or more blocks, involving the closing of streets. But perhaps the most complete transformation of types of buildings has come in tenement and apartment houses where the bulk, or area covered, is limited by law. 


\section{LAND PLANNING IN THE UNITED STATES}

The early housing laws paved the way for regulation by districts concerning the percentage of the lot which is permitted to be covered by various types of buildings. The enforcement of the zoning laws does not produce ideal conditions, necessarily, but the regulations are quite generally enforced. The result has been a distinct gain in access to light and air for occupants of buildings erected under the modern zoning laws.

Use Districts. - The designation of use districts should be carefully correlated with the comprehensive city plan in which the different zones are located with proper regard to the street system, transportation and the special facilities which are needed for adequate service to each class of uses. Otherwise the mistakes of the past may be projected into the future. If an area is to be made commercial merely because, under the unrestricted, haphazard methods, stores have been set up among the homes whether the area is suited to stores or not, zoning will have a limited beneficial influence on the city. If apartment houses are to be permitted in districts mainly occupied by single-family, detached houses, set back from the streets and surrounded by yards, merely because a few apartment buildings have crept in before the zoning law, zoning cannot render the fullest service to the community.

Non-conforming Uses.___ In most zoning laws, the principle of "non-conforming uses" is recognized; that is, existing uses which do not conform to the new zoning restrictions are frequently permitted to continue. Ordinarily no new similar uses may be introduced, though, occasionally new non-conforming uses are permitted in exceptional circumstances. The Los Angeles law contained a provision which permitted the elimination of certain of these existing non-conforming uses and under the law a Chinese laundry which had occupied its site for many years was removed from a residence zone. Most laws do not contain a retro-active clause, though there is much to be said for eliminating certain non-conforming uses which are particularly detrimental to an entire neighborhood, after a definite period of years. Sometimes this is accomplished in effect, by 
refusing permits to remodel or enlarge buildings put to such non-conforming uses. It is recognized that exceptions should be made for some non-conforming uses where the injury to surrounding property is small or non-existent and the advantages seem to offset the disadvantages.

Classification of Uses.-The tendency of the first zoning laws was to put into effect restrictions which would protect the so-called higher uses from lower uses. This was done on the theory that homes needed protection from offices and stores and commercial districts needed protection from industrial plants. More modern thought and practice are developing the theory that each of the zones needs special provisions in the city plan and that industry needs protection from mixed uses of land quite as much as offices need protection from industry. Land which is served with expensive heavy pavements, with costly railway and water transportation facilities, with street arrangements adapted to industrial uses, with factory sites larger than block areas, is not suited for residences. Homes may be built in locations which offer better facilities for enjoyment and on land which can usually be purchased at a lower price. The needs for the width, arrangement and paving of streets for large manufacturers and for retail merchants are totally different, and the patrons of each, when they are not segregated, impede the dispatch of the other.

Blighted Districts.-During periods of industrial expansion, of course, vacant land, not yet claimed, may not seem to possess immediate value for industrial uses. Sometimes industrial development encroaches slowly upon existing residential areas which have been abandoned by their original possessors and have passed through a period of neglect and become "blighted" districts. Chicago, Saint Louis, Cincinnati and other cities have long suffered from such afflictions. Wise city planning and zoning prevents such "blighted" areas. Adequate space for expansion of industry and commerce is provided.

But most of our cities were built before city planning and zoning were understood and applied. In these existing cities, 
where the outward push of business makes it expedient to transform a residence neighborhood into a commercial district the change can be made by application of the property owners to some established tribunal, which, in the absence of any city-wide reason to the contrary, would presumably approve changes based on sound judgment. Thus the character of an entire block might be changed in a way to avoid a period of undue property depreciation and consequent slip-shod appearance and loss of taxes due to unsuitable use of buildings.

A residence may be turned into a haberdashery or a real estate office in an unzoned city and the enjoyment of the neighboring home owners may be seriously affected. As a result it might prove difficult to sell the property for its full residence value, and if the block is not yet in line for immediate business development, property owners are forced to suffer inconveniences if they occupy their houses for residence purposes or to incur financial loss if they move. Under a good zoning law no business would be permitted to enter a residence block until the need for business in that locality became so thoroughly established that the home owners who would be pushed further from the center of town could sell their residences for business purposes without loss, sometimes, even, at a substantial gain. But the power to determine the path of business would be placed in representatives of the community and not left to chance or to the selfish, premature moves of individual property owners.

Wholesale loss to property owners and unnecessary sacrifice of taxes to the city from the "blighted" districts have frequently resulted by reason of the selfish or ill-considered action of a single property owner who sold his property for uses which foredoomed the decline of the entire district. Under good zoning laws, residences may not be put, one by one, to uses which ruin the neighborhood. Sweat shops and small factories established in abandoned homes prevent in many cases the sound business development which might have followed the residence period. The blighted areas, harboring unsanitary 
crowded living conditions and all sorts of miscellaneous manufacturing, become forsaken spots. No well-zoned city need suffer from such economic and social maladjustments.

Neighborhood Stability.-Zoning, when wisely designed and properly applied, sets and maintains the character of an entire neighborhood. A home owner does not select a home for the house alone. A good house in a poor neighborhood will often be rejected for a poor house in a good neighborhood. The house can be improved by the owner through his own independent action. The neighborhood can be improved only through the joint action of the many owners by agreement or through community control. A retail merchant does not select a store building for its equipment. Rather, he selects a location where he believes that he can compete with other retail merchants in the same business. Many a retail shop has weathered lean years of business or been forced out of business when it moved prematurely into a new neighborhood. The investment of a retail merchant is in large part in the location. Through zoning his investment in this respect is protected by the stable character of the entire section.

Zoning makes it possible for the city and property owners to co-operate in providing the special facilities for each district which will prove most convenient for the needs of the district. Narrow traffic ways, narrow footways, street trees and parkway spaces may be provided for home districts; wider traffic ways, wider footways, street trees and parkway spaces may be provided for apartment house districts; wide traffic ways, wide footways and sometimes street trees may be provided for retail business districts; wide heavily-paved streets with sidewalks adjusted in width to the foot traffic may be provided for factory districts. In mixed districts it is not possible to adapt the arrangement of the streets to the diverse needs of residence, business and industry.

The broad thoroughfares carrying street car lines and six or eight rows of automobiles, even where there are parking strips of grass and trees, are coming to be shunned by those who 


\section{LAND PLANNING IN THE UNITED STATES}

erect private residences. Yet such broad streets, even when unrestricted against heavy trucks, as they emerge from the business districts, are excellent locations for apartment houses, since the upper stories are removed somewhat from the noise and dust of the street and the width demanded for traffic also provides added opportunity for sunshine and air.

There Is Danger in a Ready-made Zoning Law.Even the general principles of convenience for different classes of industry, commerce, trade and living conditions cannot be applied definitely to all cities alike. Each city has its own activities, its special physical advantages and handicaps, its own local customs in types of buildings, its own past, present and future. Each city which has arrived at maturity and a large population, unzoned, suffers from special existing conditions which neither the enterprising Philadelphia lawyer nor the zoning expert can promise to correct entirely by a tardy zoning law.

To secure the best results every city needs to profit by the experience of those who have studied zoning as applied to other communities; but more important, even, is an exact, detailed and comprehensive knowledge of the physical city, the customs of the people, local activities and the trend of development. It is not always those who have lived all their lives in a city who know and understand what is going on about them. But in every city there are citizens who have in their possession knowledge of the uses to which land has been put over a long period of years. These have a large contribution to put in the hands of zoning experts. A zoning survey reflects only present uses.

The zoning of a city requires expert professional knowledge just as the presentation of a case in court requires legal training. But as the lawyer depends upon the layman to secure his facts, so must the professional zoning expert rely upon the citizens to secure the immense body of accurate information upon which any good zoning regulations must be based.

Zoning, as has been said, is closely tied up with the City 
Plan. The backbone of the city plan is the network of streets which provide major and minor transportation routes. Traffic can be guided to its appropriate destination only when industrial and commercial districts are established with some degree of stability. The fact is that it is the attempted application of an intelligent city plan which has disclosed the urgent need for use districts. To what purpose would one generation of publicspirited citizens construct at great expense a broad traffic highway leading to a commercial district which, in the next generation, will have shifted to another locality? The city plan lays down the broad general outlines of the future city. Zoning by regulation under the police power prevents individual citizens from breaking away too far from the ideal set up by the city plan; but through the method of establishing zoning commissions with power to define districts, or through placing the power to define districts in the established authorities, with proper technical advice, the realization of the city plan is approached by property development suited to each decade of expansion.

Zoning is vitally concerned with the location under the city plan of rail entrances, water fronts, civic centers, public buildings, parks and playgrounds, as well as the location of homes, offices, stores and factories. A city can be guided to sensible growth only by a careful dovetailing of the zoning districts with the designation of the principal features of the city plan.

The Zoning Law of New York paved the way for the zoning development in this country, and while zoning has taken a slightly different trend in some of the western cities, we may consider that in studying the New York experience we are examining, if not a prototype, at least a precursor of most of the zoning laws in the United States.

Mr. Edward M. Bassett has given a brief definition of the New York zoning law:

"Zoning has nothing to do with private restrictions. It is the method by which the community protects itself against harmful invasions of buildings and uses under the community power, com- 


\section{LAND PLANNING IN THE UNITED STATES}

monly called the police power, the same as it protects itself against fires by fire laws and disease by health laws. This power rests in the State legislature, but the legislature can grant it to cities. The legislature has granted to the Board of Estimate of Greater New York the power to regulate the height, area and use of buildings. The Board of Estimate, pursuant to this grant, enacted the zoning resolution in IgI6. It consists of a resolution defining the regulations and three maps, one showing allowable heights in different parts of the city, one showing allowable cover of lots, and one showing allowable uses. The height districts run from three-fourths to two and one-half times the width of the street. The area allowances run from roo per cent in A districts to 25 per cent in $F$ districts. Use districts are residence, business and unrestricted. The resolution is not retroactive; consequently buildings and uses in existence'prior to July 25 , I916, are not affected. Every borough is zoned on the three maps. The Board of Estimate can amend the resolution and maps, and does so on petition at almost every meeting. The building commissioners will not issue permits unless the plans of proposed buildings or alterations conform to the zoning resolution. As many exceptional situations exist in the diverse field of buildings, and as no words or maps could provide for all these exceptions, the city charter provides that a Board of Appeals can, after a hearing and in accordance with prescribed rules, vary the strict letter of the law regarding particular permits. Its decisions are subject to court review."

It will be observed that the process of obtaining the New York law was, first, the passage of an enabling act by the State Legislature which definitely delegated to the city the power to zone; second, the passage of zoning resolution or ordinance by the Board of Estimate, defining the regulations and adopting three sets of zones or districts shown on three separate maps; third, the placing of definite power in the Board of Estimate to change these districts by amendment to the resolution; and fourth, the establishment of a Board of Appeals, with power, after a hearing, to vary the absolute application of the regulations to fit exceptional instances. There is still one further step which may occur and that is the revision by the courts of the decisions of the Board of Appeals.

In January of $1924 \mathrm{Mr}$. Bassett summarized the experience 
in New York which had determined the interrelationship between the Board of Estimate, the Board of Appeals and the courts.

"The zoning resolution has now been in operation more than seven years. During that time none of the regulations has been declared unconstitutional although many cases have gone to court. The blanket approval of the highest State court was given the zoning resolution with the proviso that its detail provisions must be kept reasonable and adapted to protect the health, safety and general welfare of the community. . . .

"The Board of Estimate under the charter has entire control of the resolution and maps. The Board of Appeals has absolutely no control. The Board of Estimate has absolutely no power to pass on specific permits. The Board of Appeals can vary the literal provisions of the law (I) in cases provided in the resolution itself like temporary permits, garages in business districts, eighty percent garages, etc., and (2) in exceptional cases of practical difficulties or unnecessary hardships where the strict letter of the law is confiscatory.

"The safety valve function of the Board of Appeals is necessary to prevent numerous cases of unreasonableness and partial confiscation. If it were not for the Board of Appeals there is little doubt that a lawsuit would arise every month that would cause the courts to declare the zoning resolution unconstitutional in the case of some particular permit. This would not be equivalent to declaring the entire zoning plan unconstitutional. But after the courts had punched fifty or a hundred holes in the zoning plan, officials and property owners would begin to disregard it. It would be on its way to the scrap heap.

"Here are some illustrations. Sometimes the Board of Appeals allows a moving picture theatre or a garage to extend from a business into a residence district on the condition that there shall be no openings in the wall within the residence district and that such wall shall be laid up with face brick. Sometimes an owner of an irregular plot of land is allowed to vary the location and sizes of his yards and courts so as to prevent hardship and to carry out the spirit of the zoning. In all such cases the owner is assisted to a reasonable solution of his problem. If he can get a commonsense solution he usually does not care to test the constitutionality of his particular case, and the chances are that he would be defeated if he did, inasmuch as he has had a fair hearing before a tribunal empowered to adjust his problem. Interested persons aggrieved by 
any decision of the Board of Appeals may have it reviewed by the court. The court, however, considers that the board is a body of experts, and it will not overthrow the decisions of the Board of Appeals if they are within the provisions of the law and if due discretion has been used, even if the judge (as happened in one case) considers that he would have decided the case differently if he had been on the Board."

It was feared by some of the advocates of the New York Zoning law that the Board of Estimate would make so many changes in the districts that the regulations would be weakened and the purpose of the law nullified. After making a careful count and analysis of the changes, Mr. Bassett declared that "during the past three years the strengthening changes exceeded the relaxing changes, and that each year since the zoning began the proportion of strengthening changes increased over the preceding year. These figures show not only official support of the zoning plan, but they show clearly that property owners are gradually favoring the strengthening of the zoning requirements rather than their relaxation:"

The experience of New York in regard to blighted districts is illuminating. We have described how these blighted districts have crept into many of our cities.

"Every part of the city was open to the exploiter. He could erect a building of any size, height or shape in any place and put it to any use however hurtful to the neighborhood. Sometimes it was storage of trucks in a good tenement district. Sometimes it was a six-story tenement in a locality of neat small cottages. Sometimes it was a metal factory in a home district. Frequently a varnish or paint works or some other nuisance factory would buy an acre or two of land in the suburbs and establish itself in the heart of what ought to become an area of small homes. When the growth of the city forced home building in that direction the good homes would avoid the factory. The surrounding twenty or more acres would be left vacant for a time and then perhaps build up with cheap and squalid structures.

"The zoning plan put a stop to this chaotic building. Invasions of harmful buildings and uses were prevented. Business districts are protected against industry, apartment house districts against business, and cottage districts against apartment houses. 
"As an instance of zoning preventing blighted districts, the north side of Washington Square and parts of Greenwich Village are sometimes referred to. Before the zoning came, small industries and repair shops had begun to creep into and among the well-built private houses which had been deserted by their former tenants. Rents were low and everything appeared to be on the down grade. Then when zoning began in 19r6 many of these streets were zoned as residential. There was an immediate brightening of the locality. The large homes were altered into studios and bachelor apartments. Now rents are good, the houses are well kept up and artists complain that they are being crowded out.

"No blighted districts have begun in this city since the zoning was established, but on the contrary, some that had begun have been redeemed."

The New York Zoning law and practice is mainly serviceable to the country by reason of its machinery. New York nad already become in the opinion of many over-centralized and congested and had permitted too solid areas of skyscrapers. In New York "there is only one class of industrial district; in later ordinances there are usually two, one for light industry which is less objectionable, and the other for heavy industry, most in need of segregation." Moreover in the New York resolution, "there is only one class of residential district, in which both the one-family house and the tenement are allowed. The importance to family life and character, of the house which the family has to itself is generally admitted, and the fact that the tenement drives out the single house in any section where the tenement comes, seems clear. In the New York resolution, although there is no district in which there are specific provisions protecting the one-family house, the " $\mathrm{D}$ " districts were created in the attempt, the success of which remains to be seen, to require so much open space that in them it would not be profitable to erect tenements." New York permits a greater height for buildings than many of the Pacific Coast cities, though the eastern and middle west municipalities have followed the lead of New York in permitting high buildings.

The setback regulations which are so desirable in residence neighborhoods, especially in one-family districts, have been 
successfully defended in zoning laws. Mr. Williams sets forth the difference in theory between the older laws and the zoning regulations:

"The pre-zoning setback... requires the land-owner to leave a given part of his land open; the zoning setback in effect merely prescribes the location of a part of the space which must be left open irrespective of setback. The pre-zoning setback, affecting as it does a strip of land of the same width irrespective of the size and shape of the lot, is a burden which bears unequally upon the owners of lots of different sizes and shapes; the zoning setback, since it does not increase the required percentage of open space on the lot, if a burden, is equal for all; or if unequal does not require more than the minimum open space necessary for health. The pre-zoning setback is an isolated provision; the zoning setback, especially if a part of a comprehensive scheme, is an element of a plan for the general advantage."

Zoning has exercised a very definite influence on the abolition of billboards from residence neighborhoods and many of the zoning laws provide regulation of billboards in commercial districts. Many of the zoning ordinances contain the billboard clause. But indirectly the principle of zoning has aided in the application of regulations which prohibit billboards in certain localities, such as entrances to parks, along scenic boulevards, and other æsthetic developments of the city.

The famous Cusack case (Cusack v. Chicago, 242 U. S. 526) no doubt paved the way for zoning regulation of billboards. In this case it was successfully maintained that "a city, exercising the police power, may prohibit the erection of billboards in residence districts, in the interest of the safety, morality, health, and decency of the community."

Zoning and the Constitution.-The theory by which zoning is held not to be in conflict with the provision of the Federal constitution which prohibits any State from denying "to any person within its jurisdiction the equal protection of the laws," is that these "differing regulations are the same for all districts of the same type. They treat all men alike." Zoning "is a painstaking, honest effort to provide each district 
or neighborhood, as nearly as practicable, with just such protection and just such liberty as are sensible in that particular district. It avoids the error of trying to apply exactly the same building regulations to every part of a city or town regardless of whether it is a suburban residence section, or a factory district, or a business or financial center."

Many of the cases which have weighed against zoning have turned on the question of the power of the municipality to exercise such authority. This can be remedied by a proper State Zoning Enabling Act, or an amendment to the State constitution. Because of the importance of the proper authorization the United States Department of Commerce, through an advisory committee on zoning, has prepared "A Standard State Zoning Enabling Act," which may be adapted to use in any State in the Union.

Massachusetts adopted an amendment to the State constitution in 1918 which gave the legislature specific "power to limit buildings according to their use or construction to specified districts of cities and towns." This was followed by the State laws of 1920 under which nearly a score of Massachusetts towns and cities have adopted partial or comprehensive zoning regulations. In the past five years a majority of the States have passed some sort of laws regarding the zoning of specific cities, or cities of certain classes, or any cities or towns.

Court Decisions.- The courts are not absolutely agreed on the constitutionality of zoning, but the weight of evidence is increasing each year that the law is developing with the needs of the communities. The city of Saint Louis has suffered a set back in its zoning regulations because of a majority decision of the Supreme Court of Missouri that the ordinance "was invalid in that it imposed restrictions upon the use of private property having no relation to the health, safety, comfort or welfare of the inhabitants and constituted a deprivation of the use of same in violation of the Constitution." But the dissenting opinion of three of the judges maintained that "the great weight of authority, both Federal and State, is to the 


\section{LAND PLANNING IN THE UNITED STATES}

effect that a reasonable zoning ordinance is constitutional, and the determination as to what is reasonable varies with the changing conditions incident to modern development and civilization."

A comprehensive zoning ordinance, before the law, would have much better standing than a partial or piecemeal law, because it unquestionably "preserves the equality of classification in that all the different neighborhoods similarly situated and of like character are treated in a like manner. There is, moreover, no denial of equal protection of the laws because all property within a designated district is treated alike and stands on identically the same footing." In this connection Mr. Herbert Swan quotes the dissenting opinion of Mr. Justice Hallan, who upheld the constitutionality of zoning.

"It is said this realtor has a vested right guaranteed him by the constitution to damage his neighbors' homes by devoting his lot to a use incongruous with the use of property in the vicinity, and that no power can stop him, for to stop this damage would be to take his property without due process of law. If it be said that the owner of a lot in a district of homes has the vested right to use it as he sees fit, notwithstanding the damage to his neighbor, then what of the right of his neighbor whose property value he destroys? Has one the vested right to destroy and the other no right at all to be protected? In my judgment this slaughter of property value is something the legislature has power to prevent. Courts have exercised the power to abate what they have denominated nuisances at common law. This grocery store was not a nuisance at common law. But it does not follow that the legislature may not regulate the location of business structures that were not nuisances at common law. It may do so."

The modern theory has been clearly stated by Mr. Justice Kramer in an Ohio case:

"No one, today, I take it, would question the right of a municipality, under its police power, lawfully to limit to certain districts slaughter houses, corrals, livery stables, laundries, carpet beating establishments, etc. Not only would we consider that this might lawfully be done, but we would consider that there never could have been any question that it could not be done. Yet the books 
disclose that the validity of the laws so limiting these industries were attacked in the courts upon precisely the same grounds as are urged against the ordinance here in question. The law has not changed, but the application of the law has kept pace with changed conditions, conditions both material and of public thought. These conditions have so changed, since it was considered the right of the state to interfere with the use of private property, even to the extent of limiting its use as a slaughter-house, was debatable, that it is now held that regulations limiting the height of buildings, the material to be used in their construction, and all of the other minute limitations of building ordinances, fire district ordinances, etc., are too well established to be questioned.

"The development in the application of the law, in this regard, has been in sympathy with the change which has taken place generally from the conception that the law should jealously guard the right of the individual to use his property as he saw fit, subject only to the condition that he did not maintain a public nuisance thereon, to the conception that the state or community has a very definite interest in the use of private property, and that the use of such property may be very broadly limited in the interests of the community in general."

The progress of zoning laws during the past ten years has been little short of marvelous. The need for some such regulation had become so apparent that officials and citizens alike were willing to try the new method. Undoubtedly there will be modifications and additions to the regulations, but the general principles have been blocked out, have been put into practice and found useful. The definite regulations of zoning have appealed to the American people, possibly because they were concrete and promised fairly immediate returns. As we have explained, however, zoning unaccompanied by comprehensive planning or not carried out as part of a well-considered plan, will accomplish only a part of the benefits which should be expected. The results from comprehensive planning do not follow so closely after the decisions. Cause and effect are not so easily traced. A plan may be made in one generation and not realized until the next. Possibly because of this longrange element, the general principles of city planning have not been as generally adopted in our American cities as have 


\section{LAND PLANNING IN THE UNITED STATES}

the zoning regulations. It is to be hoped that the next decade will see a notable advance in the application of city planning principles to the growing communities of the United States.

\section{SUGGESTED READING}

Edward M. BASSetr, "Zoning in a Nutshell," a release prepared for the press. January 5 , I 924 .

Edward M. BASSEtT, "Board of Appeals Upheld by Courts," a release prepared January I9, I924.

Frank B. Williams, The Law of City Planning and Zoning, The Macmillan Company, 1922. "Zoning in Canada and the United States." Part IV, chap. 3.

ANDREW Wright CRAWFORd, "Important Advances Toward Eradicating The Billboard Nuisance," Bulletin of the American Civic Association. Ist ed., March 20, I919, 2nd ed., March 15, 1920, p. I9.

"A Zoning Primer," by the Advisory Committee on Zoning appointed by Secretary Hoover consisting of Edward M. Bassett, Irving B. Hiett, John Ihlder, Morris Knowles, Nelson P. Lewis, J. Horace McFarland, Frederick Law Olmsted and Lawrence Veiller, issued by the Division of Building and Housing, John M. Gries, Chief.

"Standard State Zoning Enabling Act," Division of Building and Housing, Department of Commerce.

Supreme Court of Missouri on Zoning Ordinance of St. Louis, Decision rendered October 6, 1923. State ex rel. Penrose Investment Company et al. Realtors vs. James N. McKelvey, Respondent.

Herbert S. Swan, "The Law of Zoning," a review of the constitutionality of zoning regulations which control buildings in accordance with a general plan of municipal development. Supplement to National Municipal Review, October, I921.

"Zoning as an Element in City Planning and for Protection of Property Values, Public Safety, and Public Health," by Lawson Purdy, Harland Batholomew, Edward M. Bassett, Andrew Wright Crawford, Herbert S. Swan, issued by the American Civic Association, June $30,1920$.

State ex rel. Lachtman v. Houghton (158 N. W., ror 7; 1916) quoted in The Law of Zoning, by Herbert S. Swan.

State ex rel. Morris $v$ Osborn, 18 Ohio Law Reporter 22 (1920) quoted in The Law of Zoning, by Herbert S. Swan.

Report of the Heights of Buildings Commission to the Committee on the Height, Size and Arrangement of Buildings of the Board of Estimate and Apportionment of the State of New York. December, I9I3. 


\section{REGIONAL PLANNING}

As city planning principles came to be applied within the cities and towns it soon became apparent that control over highways, transit and transportation, water, sewage and drainage systems, parks and recreation spaces and many other elements of the physical environment, was totally inadequate if it stopped at the city limits. We have long had metropolitan areas for sanitation, for park systems and for other specific purposes. The States, in addition to delegating certain city planning and zoning authority to incorporated cities and towns, have frequently created special sanitary and park commissions to deal with described metropolitan areas.

Of course in New England, where the State is divided into towns which cover the entire surface of the map with no intervening areas, we have a situation which is quite different from the States where the territory is divided into counties and the incorporated towns and cities occupy fragments of counties, leaving much space to the county authorities who are, in general, supplied with limited funds and rather vague responsibilities. In New England, metropolitan districts have been formed by co-operation of a number of towns.

The Boston Region.-Boston is an excellent example of the development of the idea in New England. In I 889 the Metropolitan Sewerage Commission was created for eighteen towns, including Boston, Cambridge, and other towns in the vicinity. As an innovation this step was opposed by some of the conservatives of that day and there was a determined attack on the constitutionality of the act of the legislature; but the law stood and in 1893 the Metropolitan Parks Act 
created a metropolitan park commission, so that "in the important matters of a wise provision for outdoor recreation and the preservation of forest, shore and river front, Boston and its neighbors are in effect a single community." In I895 the Metropolitan Water Act provided for the "business enterprise of supplying water at cost to Boston and the neighboring towns and cities," by which an "abundant supply of pure water is obtained by all the inhabitants of the district, and in no case is the cost of the water to the consumer greater than in the old days of local individual sources of supply, and in many cases it is far less."

In I90I the process of combination began with the consolidation of the Metropolitan Sewerage Commission and the Water Board. In I9r9 the Water and Sewerage Board joined with the Park Commission to form the Metropolitan District Commission with jurisdiction over thirty-eight cities and towns.

The tendency is unmistakable. The Metropolitan District Commissioner in 1922 expressed the definite opinion "that the growth and evolution of the Metropolitan District in a third of a century" probably pointed "to a greater growth and further evolution in the years to come."

The Metropolitan District Commission is predominantly an administrative board. Its significance lies in the fact that it establishes a metropolitan area. In r923 there was created by the General Court (legislature) the Division of Metropolitan Planning, and the Governor named three representatives of the Commonwealth to serve with the representatives of the Commissioner of Public Works, the Chairman of the Department of Public Utilities, the Chairman of the Metropolitan District Commission, and the Chairman of the Transit Department of the City of Boston on the Metropolitan Planning Commission for the forty cities and towns of the District. The provisions of the act instruct the Metropolitan Planning Commission to "consider all types of transportation services and facilities (both passenger and freight) within the Metropolitan District whether upon highways, waterways, railroads, 
or street railways." For convenience the Division divided its work into three sections, (I) Highways and Highway Transportation, (2) Rapid Transit, and (3) Port, Railroad and Trolley Terminals.

Thus, through the District Commission and through the Metropolitan Planning Commission are brought into unified jurisdiction the forty cities and towns of the vicinity of Boston. Many of these towns trace their beginnings back to the early settlements in America. The movement toward regional planning has been slow and is not yet complete, but the trend is quite clear. The Boston experience is quoted at the outset because it illustrates the development of the idea.

The Los Angeles Region.-On the other side of the continent, in a district which has been developed during recent years, a regional planning movement has culminated in the appointment in January, 1923, by the Board of Supervisors of Los Angeles County, of the Los Angeles County Regional Planning Commission, said to be the first official regional planning commission in the entire country.

The metropolitan area covers only a part of the county, but includes some twelve hundred square miles, forty-one cities and more than fifty unincorporated towns. "To that end the Regional Planning Commission, as an advisory body to the Board of Supervisors, assists in the exercise of the authority of the County in unincorporated territory, and secures concurrent and co-operative action on the part of the municipalities of the County. This concurrent action in the laying and executing of basic plans for future development is Regional Planning." The Commission has turned its attention to the highways, to transport, to zoning, to parks, to water conservation and flood control and to sanitation.

Theory of Regional Planning.-At the Baltimore City Planning Conference George B. Ford presented an excellent definition of regional planning. He said:

"Regional or metropolitan planning is the co-operative solving of problems common to the various municipalities within a given 


\section{LAND PLANNING IN THE UNITED STATES}

unit economic area. Any service or feature that can be made and should be used by only one municipality should not be considered in regional planning unless its location or character is detrimental to the region or to some other community.

"Regional planning usually differs from city planning in the relative area of ground covered. In a city like Worcester, Mass., for example, where the built-up area is completely surrounded by a wide belt of farming land within the corporate limits of the city, with nothing but farm land in the adjoining towns, regional planning is reduced to a matter of being sure that the thoroughfares, transit lines, bus lines and railroads leading in and out of the city are effectively located and that they can be adjusted to take care of future growth without waste.

"In other cities of exceptionally larger area in proportion to their population, like Los Angeles with its 350 square miles, or even Cincinnati with its 72 square miles, or Baltimore, the city plan covers most of the contributory area which on the other hand would have to be covered by a regional plan in the case of a relatively smaller-sized city, such as Boston, New Haven or Pittsburgh.

"This contributory area goes to the limits of the commuting belt and includes all those communities which are daily dependent on the central city for their livelihood, social life or for the supply of commodities. In Buffalo, Boston, Saint Louis and Cleveland this area has a radius of 20 to 25 miles; in New York the radius is 40 to 50 miles; in New Haven, Norfolk and Omaha the radius is about I5 miles."

Thomas Adams has pointed out that the hopeful thing about regional planning as compared to city planning is that regional planning deals very largely with areas which are still undeveloped, areas in which it is possible to prevent the sort of conditions we find it so difficult to cure, and where the remedy is at hand without the excuse that we are dealing with a situation inherited from the past. Regional planning, even more than city planning, provides a method for guiding the future growth of the city intelligently. It rests with those who live now to decide how the growth of the undeveloped areas around the cities of to-day should be controlled and directed in the future.

In the problem of highways the city planner is handicapped by the existing distribution of the population. His arterial 
street system must carry people from the places where their homes are to the places where their employment lies and to the places where they market, shop and find their entertainment. Occasionally it has proved possible to destroy or move bodily acres of buildings used for one purpose to make room for new structures devoted to new uses. But this is an expensive remedy for earlier mistakes. But the regional planner may determine the uses to which certain sections should be assigned. A highway system planned to provide routes to carry freight and passengers from sections located scientifically in relation to each other is a vast improvement over the compromise makeshift which we have inherited in the overgrown, congested cities of the past century.

Probably the most obvious field for first-aid in regional planning lies in the provision of adequate circulation of traffic by water, rail and highway, for business and for pleasure. The pleasure travel in the parkways which form the outer park systems of metropolitan areas is involved in this and the relation between highway systems and parks and parkways is quite as close in the metropolitan region as within the city limits. But in order to design or remodel a highway system or route suburban railways it is necessary to know the uses to which the various districts will be put. And in order to secure any sort of stability in character of any given district we need zoning.

But it is one thing to zone a metropolitan region with the purpose of making the best use of the land from the point of view of the entire region, and it is quite another thing to permit each city and town in the region to adopt zoning regulations which may protect one district at the expense of another. Mr. Ford cites the instance in which "a number of the cities and towns around Cleveland have been adopting stringent building zone ordinances which often exclude all industry and severely limit the spread of business. In other words, they have zoned against the city of Cleveland which will thus be obliged to provide common, economic facilities for the sur- 


\section{LAND PLANNING IN THE UNITED STATES}

rounding communities." The great concentration of populations during the past quarter of a century has resulted in the superimposing of the outskirts of one city or town upon another. The main city pushes outward. The suburbs frequently push inward as well as outward to meet the tide of population. The metropolitan region is not unlike a network of cells of different sizes and shapes all gradually enlarging their circumferences until at certain points two, or even three, cells overlap. The futility of trying to zone these separate cells as though they were isolated will readily be apparent.

Regional zoning, like municipal zoning, however, is closely related to comprehensive regional planning. The proper location of industry, to cite a single instance, is most important in any regional plan. Mr. Robert Whitten points out the fallacy of careless location of industry.

"Take the case of the industrial town with heavy industrial plants located at its outskirts. When the great city has swept over it, the once cheap land on which the large acreage industry is located is assessed for taxation at $\$ \mathrm{I}$ or more a square foot. The industry cannot be moved without scrapping the entire plant and it cannot be expanded without paying an exorbitant price for the additional land. Of course the increase in land value may offset the cost of removal to a new location, but the transaction nevertheless represents an enormous economic loss to the community. A considerable amount of such shifting of industrial location and consequent economic waste is inevitable in city growth, but wise planning and zoning can prevent much of it.

"It should be possible so to plan the industrial suburb that its industries will not be driven out by high taxes, by lack of room for expansion or by the crowding out of its supply of efficient labor through high rents and congestion. A first essential is a permanent physical barrier to the engulfing sweep of the great central city. If no natural barrier such as a broad river exists an artificial barrier should be created."

\section{Mr. Whitten believes that}

"The suburban or satellite town offers our only hope of substantial relief from the increasing congestion incident to the ever growing bulk of the great city. There seems to be no definite 
limit to the possibilities of such growth. But if this growth instead of further congesting the central city proper is distributed among a considerable number of suburban or satellite towns the problem is much less serious. A suburban town near a great city offers the opportunity for almost ideal living and working conditions. But judging from the past the suburban town of today will tomorrow become an integral part of the great city. Its individuality and its suburban characteristics will be lost in the engulfing sweep of the great city over the smaller and the obliteration of its physical or political identity or both have had unfortunate results both economically and socially."

Regional zoning is coming to be recognized as an aid in decentralization of population. The crowded down-town sections of New York City are not only congested with industries which might be located in near-by towns, but the proper treatment of sidewalks and street traffic is made almost impossible because of the mixed nature of the uses to which the buildings are put.

An imaginery conversation between two strap-hanging citizens in New York brings out these considerations. The first citizen complains that all the improvements the city planners effect only serve in the end to increase the number of people who come into New York and increase the congestion.

"At tremendous expense," he declares, "they widen a few streets, zone a few districts, and even secure a few parks and playgrounds. We pay outrageously and before we have caught our breath, everything is as bad as before."

\section{The second citizen makes reply:}

"I doubt whether the interest of the merely expanding city serves the interest of the region in which it lies. As a matter of fact, as one studies large cities and their evils, one begins to doubt whether it is even to the interest of the city itself to expand further. We all know the type of business man who wants his city larger and larger every year. If he lives in a city of half a million, he forms clubs to 'boost our city-make it a million!' We do not seem to realize that continual crowding into big cities will soon arrive at a point at which living must necessarily become prohibitive.

"And do you know that New York State has really developed 
only a small section; that 75 per cent of its population lives on less than I5 per cent of its area? New York City has 50,000 to the square mile, and within ten miles you can find areas where there are only 500 to the square mile. Fertile farm land is wasted; localities that would be ideal for industrial purposes are under-populated, while other districts are so over-populated that even their economic efficiency is impaired. ...

"Is there any reason why the clothing industry, for example,I could name half a dozen others,--should be located in the central part of the city? Why can't such industries go to other localities, taking their workers along? Do you think that industry thrives best on over-concentration?

"The decentralization of population and industry is taking place already, although very gradually, as a result of the economic inefficiency of over-concentration. That very process is a challenge and an opportunity for us to plan more broadly, so that the new communities will grow without over-developing any one center. For after all isn't the whole aim of planning to promote better and less complicated living?"

The careful detailed studies now being conducted by the Committee on the Regional Plan of New York and its Environs will bring to the attention of the public certain definite trends which already exist and enable the Committee to make fairly accurate predictions for the future. The study of the metal industry discloses the fact that "since I900 metal manufacturing in New York and its environs has changed from a predominantly heavy industry to a predominantly light industry, the heavy branches having grown slightly and the light branches very greatly." It may surprise some readers to learn that the metal industry is the largest employer of labor in the region, that more than a quarter of a million workers are occupied in the metal industries. Dr. Lanfear traces the tendency of the plants designed to give service to locate at "convenient points in spite of the fact that such points are often near the center of things, on valuable land." He notes the location of high-class jewelry shops in Manhattan, often on very high-priced land because of their dependence on accessibility of market. But the larger plants, he says, "show a very interesting tendency to move out from the center." 
The food industries, while they are quite varied in their needs, deal at some stage of manufacture with perishable product or at least product which deteriorates under certain conditions. Many of these industries, therefore, find it highly important to be located at points of convenient trans-shipment between water and rail. Miss Williams, in the volume on "The Food Manufacturing Industries," believes it possible "to defend the position that there are only two groups of plants which are likely to remain in Manhattan below 59th Street indefinitely. First, there are those which require a large and fluctuating number of dependent wage-earners; and, second, those which gain a particular advantage in distribution by remaining there. The first group includes cracker, biscuit and candy plants; the second bread and cake bakeries (and possible slaughter houses), ice-cream plants, and other food industries catering to the inhabitants of the district below 59th street."

These tendencies are quoted only to show their importance in the problem of regional zoning. When every individual manufacturer must find his own location and must submit to changes in the use of land surrounding him over which he has no control and over which there is no community control, it must be readily apparent that land will not always, or even generally, be put to the use for which it is best adapted nor will the manufacturer find just that combination of convenience of transport and land value which his particular industry needs. Regional zoning should aid individual manufacturers to choose factory sites which offer the greatest economic and social advantages for the particular industry to be served.

Regional Planning and Open Spaces.-The preservation of adequate open spaces is a most important feature in regional planning. In addition to the outer parks and parkways of a municipality there are the forest preserves. But there are other open spaces not designated for recreation which, however, do add their quota to the areas not covered with buildings. There are the "cemeteries, aviation fields, large 
acreage institutions, fair grounds, amusement parks, railroad car storage and classification yards" and even private estates, golf and country clubs.

A control of new subdivisions gives more scope than the remodeling of many existing features. In general the subdivision is planned on open areas, with perhaps a few existing buildings to be preserved. The street system must tie into the regional highways. But there is much more opportunity for planning than in any other phase of city extension.

In 1923 in Los Angeles County there were recorded maps of 1434 subdivisions, nearly a 50 per cent increase over 1922 and far more than doubling the number for $192 \mathrm{I}$. "The larger number of these subdivisions were in unincorporated territory and thus directly under the jurisdiction of the Regional Planning Commission, that jurisdiction extending to recommending to the Board of Supervisors the conditions to be met in a subdivision as prerequisite to the recording of a map."

It can readily be seen that if there is not established a very definite platting control of areas outside the city limits and if that control is not placed in the hands of trained city planners the damage will have been done by the time the city limits are extended to include the suburban settlements. In some cities the city planning commission has been given jurisdiction for an area of three to five miles beyond the city limits. This was an excellent arrangement when nothing better could be obtained. But the more modern and efficient method of controlling the physical development in a metropolitan area is by the establishment of a regional planning district.

Unofficial Regional Plan Associations.-In 1923 the Chicago Planning Association was organized to promote a plan for the region around Chicago. In an address at the inauguration of the Association, Frederic A. Delano contrasted the problems of city planning and regional planning. City planning, he thought, might be conceived of as a big job of replanning and reconstruction, whereas regional planning involved laying out for the future the suburbs and the open 
country. Of course the Forest Preserves of Cook County had already paved the way for regional thinking, and it seems certain that the Cook County Region will be supplied with a scientific plan for future growth.

But perhaps the most extensive unofficial regional plan studies have been undertaken by the Committee on the Regional Plan of New York and its Environs. In May of 1922 the Russell Sage Foundation announced the project of developing a comprehensive regional plan of New York and its vicinity. The area under observation comprises 5528 square miles and in 1920 it had a population of about nine million people. In this district there are wide extremes of density of population-from over one hundred thousand per square mile in Manhattan to less than fifty in Putnam county. In order to secure the basic information necessary for planning, extensive physical surveys of all sorts are being carried on. Economic and industrial inquiries are being conducted. A survey is being made of social and living conditions. The existing city planning powers of the three States and of their counties and municipalities are being ascertained and a study is being made to develop the character of new legislation needed to carry out the plan.

It may be imagined that, since New York is already rather a populous metropolis and its many satellite cities are well spread over the map, it would be of little value to plan for the future at this late date. We have already shown how many evils of city building may be modified by gradual changes which conform to a conscious plan. But, as a matter of fact, there is much area in the vicinity of New York yet to be developed. It is not yet too late to make a regional plan which shall make a better use of existing physical features of the settled sections and which shall plan definitely for the best sort of development of the open stretches. Sometimes by rather slight changes existing roads can be connected into arterial and major traffic highways. We have already shown how classification of highways and traffic can aid in congested 
cities. The same principles applied to entire regions can produce equally good results.

The citizens of Toledo have recognized the need for a larger planning area and have created the Lucas County Planning Commission to provide for the orderly development of highways, parks and other planning features.

There are, of course, numerous examples of the creation of special physical districts to deal with specific problems which are not confined to the established political divisions.

The Miami Conservancy District of Ohio, covering Dayton, Springfield, Hamilton and $\mathrm{I} 2$ cities and villages, was established in 1915 under an act of the legislature passed the year before for the purpose of constructing and maintaining dams and channels for flood control.

The Sanitary District of Chicago, recently called to public attention because of the controversy over the diversion of waters from Lake Michigan, was created by an act of the legislature in 1889. The District was set up for the purpose of constructing and maintaining a sewerage system which should keep the water of Lake Michigan uncontaminated and for the development of hydroelectric power incidental to the operation of the drainage canal. The area of 436 square miles includes Chicago and 49 cities and villages, with a total population of $3,213,000$.

The Washington Suburban Sanitary District was created by an Act of the Maryland legislature in 1918 for the construction, maintenance and operation of water and sewerage systems and the supervision of street layout and platting. The district does not include any part of the District of Columbia, but only an area of 95 square miles adjacent to Washington entirely within the State of Maryland.

In I92 I Oakland, California, and eight other cities and villages joined together to form the East Bay Municipal Utility District to provide an adequate water supply for the 600,000 inhabitants of the district.

The South Park Commission of Chicago, created in 1869 
under a charter issued in 1869 by the Illinois legislature controls an area of 95 square miles, with a population just under a million, comprising parts of Chicago and Cook county. It is one of the most famous of the metropolitan districts which cuts across political boundaries, but while the commission may be cited as an example of outstanding achievement in the establishment of neighborhood parks, it controls only the parks of the south side of Chicago and could hardly be used as a model for a metropolitan park system which covers an entire city and its environs.

The State of Rhode Island established a Metropolitan Park Commission in 1904. The Commission controls an area of 176 square miles with a population of 425,000 , including Providence and ten near-by cities and villages. In twenty years the metropolitan park system of over 1200 acres has been developed for the benefit of the district.

A less official and more comprehensive plan has been developed by Chauncey J. Hamlin of the Buffalo City Planning Association and Chairman of the Executive Committee of the National Conference on Outdoor Recreation called by President Coolidge, in the project to promote a regional plan for the Niagara Frontier. The district comprises Erie and Niagara counties in the State of New York and six cities and twentytwo villages, including Buffalo and Niagara Falls. The organization is entirely voluntary, but practically all of the political units have been invited to name representatives. "The Niagara Frontier plan proposes to develop new communicating highways, parks, rapid transit facilities, regional zoning to provide for the proper location of industry and residential areas, the location of bridges within the region and across the Niagara River to Canada, the furtherance of parkways, boulevard extensions, water supply, sewage disposal and harbor and canal improvements."

There is little doubt that during the next decade there will be created officially or unofficially some sort of metropolitan or regional planning body for every city of importance in the 


\section{LAND PLANNING IN THE UNITED STATES}

United States. Many cities have these metropolitan districts for limited purposes. Some cities have the power to control planning features for three or five miles beyond the city limits. But the Regional Plan Commission is coming to be recognized as one of the most effective methods of co-ordinating the development of a city and its environs in the various fields of action.

Planning New Subdivisions Within the Region.-The planning of suburban residence districts has reached a high level in the case of Roland Park and Guilford in Baltimore and in the more extensive Country Club District of Kansas City. Many other residence areas have been developed on similar lines because of these examples. Unfortunately we also have the speculative builder, so-called, who buys a block or two at a time and places standardized houses in monotonous rows ready for the individual purchasers. We also have the individual lot owners who each follow their inclinations without regard to any community plan.

Intelligent development of suburban property is hampered by hard-and-fast street systems designed without reference to city planning principles and applied arbitrarily or, on the other extreme, subdividers are permitted to plat their land exactly as they please, provided only that they file the plat at the city hall. The successful subdivision, considered from the service to the community and the enjoyment of the home owners, is the one in a city where, through proper planning and zoning, there are established planning regulations and an established body with technical assistance to give planning advice.

A subdivision should articulate, even if it does not conform, with the street system of the city to which it attaches; that is, it should have easy access to some arterial thoroughfare. If it is a large subdivision it will usually include through its center or along its side a main traffic artery which has direct connection with the business district of the nearest metropolis. In general, so long as the subdivision avoids jogs and dead- 
end streets in making its street connections with the surrounding property, a good deal of liberty may be granted in the laying out of the residence streets. Mr. Edward H. Bouton, President of the Roland Park Company in Baltimore, has shown how a rugged region with high hills and deep valleys may be utilized with a system of local and minor streets which add to the charm of the suburb and actually make an asset of the natural beauty of the land. Mr. J. C. Nichols has laid out the streets in his subdivisions to conform to the city plan of Kansas City in the main arterial entrance but has managed to vary the minor streets in the later developments with great success.

Both Mr. Bouton and Mr. Nichols have understood the value of adequate park reservations. No modern suburb can hope to develop along the best lines if the reservations for parks, playgrounds and school sites are neglected.

Private Restrictions.-But in addition to the general community control which may be exercised through the city plan there are in all successful subdivisions private restrictions which do not conflict with, but supplement, the public control of the area through city planning and zoning.

Mr. Nichols sets forth a "list of a few restrictions on a carefully protected subdivision."

"Billboards may be prohibited on any lot.

Lots may be used only for private residences designed for occupancy by a single family; flats and apartment houses cannot be erected.

The cost of the houses to be built must be at least a certain amount, specified for each lot.

We reserve the right to approve the plans, color, and elevation of every new house or addition thereto.

The amount of required ground frontage and side free space are specified.

There are regulations regarding the distance houses must be set back from the street, and the distance that bay and dormer windows, cornices, chimneys, trellises, vestibules and porches may project in the front or on the side from the main body of the house. 


\section{LAND PLANNING IN THE UNITED STATES}

Only a certain percentage of each lot can be orcupied by buildings and outbuildings.

The character, location, design and material of the outbuildings that may be erected are defined.

Certain areas are reserved for houses of English architecture, other areas for Colonial types, and so on, thus giving a harmonious grouping of homes in a given area.

No detached outbuildings are permitted in certain tracts."

Mr. Nichols calls attention to the method of imposing re. strictions in the Country Club District.

"Formerly building restrictions were imposed deed by deed. One result was that they ran out at different times; further, there was no satisfactory way of renewing them. Now the permanence of restrictions is all-important and we designed a new type. They extend over definite periods of twenty-five years each, and are automatically self-renewing for periods of twenty years each, unless at least five years prior to each expiration period the owners of a majority of the net acreage, execute and properly record an agreement releasing the land from the restrictions at the end of the period. It is not easy to get such releases unless the change is clearly to the interest of a majority of the property owners."

Writing in I9I2, Mr. Nichols maintained that the city planning of that day needed to be supplemented by wise subdivisions of the real estate men.

"The thought of the great city planners of to-day seems to be centered around the location of civic groups of buildings, the establishment of parkways and boulevards, the creation of trafficways for increasing the efficiency of the transportation of their cities-all splendid works; yet, those are no more important to the future of American cities than the guarantee to the man who puts $\$ 1,000$ in his cottage, or $\$ 100,000$ in his mansion, that his surroundings will remain permanently good and attractive for residence purposes."

Shopping Centers for Subdivisions.-For many years we have been familiar with the corner neighborhood grocery and scattering stores to serve the needs of the residence community or suburb. But the development of the planned subdivision has brought definite consideration of shopping centers 
located in a designated area with the specific purpose of serving not only the every-day needs of the residents but offering a great variety of carefully-selected merchandise. The zoning regulations have contributed a method by which such shopping districts can be supplied to residence neighborhoods without curtailing the enjoyment of home owners in their premises.

Mr. Nichols has described very completely in the Journal of Land and Public Utility Economics for January, 1926, the decentralizing tendency of these outlying shopping centers. The great metropolitan department stores cater to shopping tours into town; but the small, personally-conducted shops, conveniently located near home, with ample parking space in front, are claiming good patronage.

Mr. Nichols lays down sixteen important considerations in the planning of such shopping centers: the streets should be wide enough to permit diagonal parking, preferably with a paving width of 72 feet; interior loading courts or 24-foot alleys are recommended; height of buildings should be held to one or, at most, two stories; short blocks are desirable; through traffic is a disadvantage and should be by-passed around shopping centers; massing the shops in contiguous blocks is a traffic aid; the grouping of related shops deserves attention; cleanliness and harmony of design, reasonable regulation of billboards, control over signs and store fronts and the keeping of streets and sidewalks free from unnecessary obstacles are urged; variety of design, careful arrangement of lighting for streets and store fronts and general attention to layout are needed. These shopping centers are made much more appealing through the provision of open squares, plazas, little parks or spaces for fountains or statuary, the planting of grass, trees, flowers and shrubbery. In general, small groups of shops might be approximately half a mile apart with larger general groups one or two miles apart.

Sunnyside, a subdivision of a thousand lots, erected by the City Housing Corporation on Long Island, was held to the rigid New York street plan, with streets sixty and eighty 
feet in width. In spite of this obvious handicap, the suburb has conformed to certain self-imposed restrictions. The houses are only two rooms deep. Four stories is the maximum height. In general it is expected to cover about 28 per cent of the land with buildings, leaving some 70 per cent open for playgrounds and gardens. Through private restrictions, the use of the interior of the blocks for garages is prohibited. Conveniently located garages are provided at low rentals. The community is given a space in the center of the block for recreation by reason of easements granted by the owners. About two-thirds of the purchasers up to May, r925, had incomes of less than $\$ 3000$ annually and a few were in the $\$ 1500$ class. The significance of Sunnyside is that a demonstration has been made to show that homes provided with modern conveniences and access to light and air, and surrounded by gardens and recreation spaces, have been built within easy access to the New York business section for families of modest incomes. Under less rigid street handicaps, in the vicinity of other cities, the experiment could be repeated and the physical layout improved.

The subdivisions carried on in thousand-acre plots have great advantage over the ten-acre lots and the individual building lot owners. The small subdivision may, by wise management, in communities where there are good planning and zoning regulations protect the purchasers of homes to some extent. But, unless there is some co-operation between contiguous developers, the surroundings of the neighborhoods are apt to vary. Moreover, it is difficult to provide for any informality of street plan except in fairly large areas. The experience necessary to adopt and apply the private restrictions which really protect home buyers is often not within the reach of the occasional owner who desires to place his property on the market for homes. But the most important shortcoming in the mosaic of small subdivisions is the lack of continuous subsequent control of the neighborhood after the homes are occupied. 
In most successful subdivisions there is some provision for community action and community control which extends beyond any municipal function of government. Frequently, subdivisions are developed in connection with a country club, which provides facilities for outdoor recreation. Mr. Nichols speaks also of the intangible elements which tend to enhance values and to make the purchase of a home a good investment. Particularly he lays stress on the "residential morale," or "the attitude of the people of the community toward the community welfare," as "expressed in their willingness to take part in an organized effort to preserve values and good residential surroundings in the district."

Only too many subdividers to-day are timid about undertaking extensive improvements before the land is placed on the market. Mr. Nichols has related some of the things he has learned since the days of his first developments:

"At the start, everybody insisted on alleys; now we do not permit an alley to be platted on our property. In the beginning I did not think we could afford to set aside the low and broken lands for parks and boulevards; now we pay enormous prices for them for that purpose. I used to feel that a road should be the shortest distance between two points; now the longer I can make it, with curves, the more trees I can preserve by winding the drive, the more rocky ledges $I$ can have along the way, the more $I$ find it appeals.

"If at the start many improvements which we now include before we put the property on the market at all had been suggested to me, I should have thought them chimerical. But I have since found that it is difficult to do anything to improve or beautify or render permanent the values in a residence district without increasing values more than enough to pay the cost of the improvements."

The Time Element.-But there is one element which is sometimes overlooked in the development of suburbs. That is the time element. The investment involved in laying out and installing the utilities in a thousand acres of land is large. In cities where the taxes are laid from the first on the whole 
subdivision on the theory that it is improved building-lot property the annual expenses become considerable. If there are mortgages the carrying charges are heavy. If the land is held clear, the withdrawal of the capital from income and circulation for a long period of years becomes a substantial item. Many subdivisions have gone into bankruptcy because the promoters have invested large capital on the theory that the building lots would all be sold in two or three years. One of the instructive aspects of the Country Club development has been the fact that, though it now presents a unified appearance, it was purchased and put on the market in relatively small areas, increasing in size as the profits from the early plats enabled the subdivider to extend his holdings and the growth of the city stimulated the absorption of more homes each year.

Satellite Towns.-Many new towns spring up in the United States every year. Many develop from cross-roads settlements almost unconsciously. Others cluster around some industrial development or some railway transportation transfer or way-station. Most of these towns, so far as they are laid out in advance, adopt a street system and rectangular blocks which reflect the conventional idea of a town in this country. Few have profited by the advice of town planners.

Mariemont, a village nine miles from Cincinnati, has been consciously planned by John Nolen as a self-contained community, a "national exemplar" of what can be accomplished by planning a fixed area for a limited population. In Mariemont space is provided to house about 9,000 people, but, because of its location, it is expected that the town center will serve some 20,000 in all. Although the total area of the village only covers 420 acres, there is space for a thriving town. Around the village center will be grouped "every sort of shop, markets, a theatre, hotel, office building, banks, post office, public library, and a town hall, all within easy walking distance of every residence." There are 50 acres of parks, playgrounds and floral gardens. Along the railway tracks will be 
two industrial sections, segregated, and assigned in advance to industrial development.

The manifest advantages of self-contained satellite cities for industrial communities were graphically presented by Graham Romeyn Taylor in 1915. More and more large industries are locating in country communities or in already-established satellite cities near large centers of population rather than in the congested districts of the parent city.

The town of Longview, Washington, on the Columbia River, some fifty miles north of Portland, Oregon, was planned from the beginning as an industrial community, first by the late George Kessler and then by Hare and Hare of Kansas City. Its scale was determined and the residence sections were placed in such a way as to give the industrial and commercial developments opportunity to expand without encroaching upon residences. A few shops, a bank and a modern city hotel were erected in 1923 . By the summer of 1925 Longview had become a town in fact as well as in prospect. Many comfortable homes had been erected, an extensive business section had been built up and occupied, and a number of industries had been established.

Both Mariemont and Longview were made possible by single ownership of the land. The problem of laying out a townsite is greatly simplified when there is a single proprietor, either an individual or a corporation; though the method used by George Washington in securing control of the area for the Federal City could be used to-day with great advantage.

In California, near Los Angeles, a future town, Palos Verdes, is being laid out by a group of experienced town planners and engineers headed by Frederick Law Olmsted. In Florida many new towns and suburbs are being built, some well planned, others failing to take full advantage of the professional advice of planning experts.

In the building of towns, as in the construction of suburbs, the time element is an important feature. The adjustment of taxation to bear a proper relation to the value of the occu- 


\section{LAND PLANNING IN THE UNITED STATES}

pied property, which in turn depends upon its income producing possibilities, and the combination of planning, zoning and taxation to encourage development of unoccupied property without overstimulation on the one hand or undue delay and obstruction to continuous progress on the other, present problems which must be met with great technical skill if land owners are not to meet heavy losses and bitter disappointments. In other words, agricultural areas, taxed at agricultural rates, may well be held for farms and gardens until they are directly and immediately in the line of development for town uses.

The facetious theme developed by Bernard Shaw that most manufacturing industries must pass through bankruptcy two or three times before the investment will yield a profit, might be applied, as a warning, to the building of towns and suburbs. The building of a town or city is really a commercial enterprise, but the stockholders are apt to be so numerous and the annual additional stock issued so considerable that it is difficult to secure responsible business management. Many subdivisions which have been well laid out physically have brought their owners or promoters to bankruptcy before they have succeeded. The economist is needed to collaborate with the planner.

But without adequate planning and zoning for entire regions, together with detailed planning and zoning for special subdivisions and satellite towns, hopeless confusion is bound to occur in metropolitan areas.

\section{SUGGESTED READING}

Second Annual Report Metropolitan District Commission, Commonwealth of Massachusetts. James A. Bailey, Metropolitan Commissioner. Feb. 26, I922.

Hugh R. Pomeroy, Secretary, Regional Planning in Practice, first annual report of Los Angeles County Regional Planning Commission, before the r6th National Conference on City Planning, Los Angeles, April 7-IO, I924.

Thomas Adams, Regional Planning, in National Municipal Review, January, I 926.

George B. Ford, Regional and Metropolitan Planning, in Proceedings of the 15th National Conference on City Planning, Baltimore, I923 
Frederic A. Delano, Regional Planning Next, in National Municipal Review, March, 1924, also reprinted for American Civic Association.

Regronal Plan of New York and Its Environs, Report of Progress, February, 1923; Maps and Diagrams; Predicted Growth of Population in New York and its Environs; A Form of State Enabling Act for Zoning; Second Report of Progress, May, r924; Traffic Problems in Their Relation to the Regional Plan of New York and Its Environs, and a series of monographs on the various industries. Detrort Bureau of Government Research, The Government of Metropolitan Areas, in Public Business, December 20, 1924.

Robert Whitren, Regional Zoning, Proceedings National Conference on City Planning, I923.

Commission of Housing and Regional Planning, State of New York, Clarence S. Stein, Chairman, Housing and Regional Planning Bulletin, New York, November, I924.

Jesse Clyde Nichols, "When You Buy a Home Site," reprinted from Good Housekeeping at the request of the American Civic Association, I924.

Jesse Clyde Nichols, Real Estate Subdivisions, American Civic Association Bulletin, November, I9I2, second edition, February, I9I6.

Graham Romeyn Taylor, Satellite Cities, A Study of Industrial Suburbs.

National Municipal League Series, I9r5.

J. C. Nichors, "The Planning and Control of Outlying Shopping Centers," in The Journal of Land and Public Utility Economics, January, I926.

\section{NOTES}

Page 250. In the typewritten annual report of the Division of Metropolitan Planning, Commonwealth of Massachusetts, for the year ending November 30,1923 , the arrangement is described:

"The common interest of all the people of the entire district in water supply, sewage disposal, reservations and boulevards is not unlike their common interest in policing, fire fighting, schooling and other public matters. Boston and its suburbs are already one in most respects. ...

"It seems, therefore, that the metropolitan district conception ought not to be weakened or the functions of the board which is carrying on the work and the traditions of the earlier commissions lessened or impaired. The Metropolitan District is unlike a department of the State government. It is a local unit or group of cities and towns lawfully banded together for the better administration of the important functions of creating one water supply from which each may obtain water, two sewage disposal systems jointly administered through which each may dispose of its sewage, and one 


\section{LAND. PLANNING IN THE UNITED STATES}

system of reservations and parkways to be enjoyed by the inhabitants of all.

"The cities and towns in the respective metropolitan districts are the real owners of the water, sewerage and park properties, and the Commonwealth, for convenience of administration and because it has lent its credit, holds the legal title and exercises certain supervision. The municipalities pay the bills in proportion fixed by law, and naturally desire to retain some measure of local selfgovernment in relation to the important functions now entrusted to the District Commission." 


\section{CITY PLANNING PROCEDURE}

City plans do not come about by spontaneous combustion. They are brought about by orderly processes which involve leadership and an informed public opinion. Harland Bartholomew has outlined six essential steps by which a community may reap the rewards of city planning.

(1) A Citizens' City Planning Committee
(2) An official City Plan Commission
(3) An definite program of procedure
(4) Preparation of a comprehensive city plan
(5) Public education
(6) Continuous application of the city plan to all public
and private work

Citizens' Committees.-In the past it has frequently fallen to the lot of the unofficial city planning committee to employ the technical staff which prepared the first comprehensive plan; but whether this task is a part of its services or not, there is still need for a citizens' committee to co-operate with the official Plan Commission to keep the public informed and to undertake definite campaigns which public officials find it impracticable or impossible to conduct.

John Nolen, in an address given before the National Conference on City Planning in 1924 , called attention to the need for better understanding of planning principles and their application on the part of the public and advocated citizens' planning committees to initiate the city planning movement before its value is appreciated by the public, to guide city planning once a program has been made, by keeping proposals before the public, and to aid the city government to put into effect 


\section{LAND PLANNING IN THE UNITED STATES}

planning projects involving special appropriations, ordinances and bond issues.

In Chicago the City Plan Commission is itself a citizens' body and has served the excellent purpose of directing a consecutive and consistent campaign of education for the citizens of Chicago, young and old.

In Dallas, George B. Dealey, editor of the Dallas Neres, and vice-president of the American Civic Association, through the columns of his paper and through the organization of a citizens' league, has kept the cause of city planning constantly before the people for a period of more than twenty years. Undoubtedly the creation of the City Plan Commission in I9I9 was due to the publicity afforded the movement. The recent organization of the Kessler Plan Association has focussed public attention on the needs of the Plan Commission.

The United City Planning Committee of Cincinnati, not only carried on an educational campaign, but raised over $\$ 100,000$ and transmitted over $\$ 90,000$ to the official Commission. The Citizens' Committee on a City Plan for Pittsburgh has raised money to the extent of some $\$ 250,000$. In Johnstown, Pennsylvania, as in Chicago, the publicity was carried into the schools with the result that the citizens of to-morrow are generally familiar with the merits of the plan and the needs of the city.

In Buffalo, under the able leadership of Chauncey J. Hamlin, a very extensive campaign of education was carried on in all parts of the city, and the printed matter appearing in the paper issued at intervals under the name "City Facts" is a model and should prove an inspiration to civic leaders in other cities. In Buffalo, as in Chicago, extensive use was made of lantern slides.

The city of Saint Louis achieved considerable attention when in 1923 a bond issue of some $\$ 80,000,000$ was voted for a long list of city planning projects.

All the modern means for educating the public may be used to promote city planning, the daily press, magazines, reports 
and circulars, technical publications, text-books for schools, popular treatises, public meetings, lectures and addresses, the forum, the debate, sermons, exhibitions, educational films, moving picture stories and the radio. We have not used visual methods as effectively as we might, partly because such methods involve a good deal of expense. Maps are bound to become of larger importance in educating the public. All individuals are not map-minded; but the almost universal use of road maps for automobile tours is rapidly bringing about a generation accustomed to read and understand maps. It is only through a map or an airplane photograph that the unity of a large region can be studied and appreciated. It is seldom possible to see with the physical eye the extent and the details of a large area.

There have been a number of excellent exhibits on city planning, some assembled for the special purpose of influencing public opinion in a specific locality, and several traveling exhibits which could be used in any town, especially if supplemented by local material. But no exhibit remains in date. The subject is developing rapidly. The cities and communities are trying new plans. New exhibit material is needed. Moreover exhibits should be classified. The sort of thing that would be useful in a town which has little evidence of city planning and no knowledge of it would be quite different from the exhibit which might be useful in a city where there had been an effective city planning commission for a decade and where important city planning projects had been undertaken and completed. In the latter case, an exhibit would ordinarily prove more effective, if it were prepared to support some pending project.

What we really need to accomplish in any campaign of education is the inculcation of standards. Unless the voting citizens have a basis of comparison and some degree of discrimination between desirable and uridesirable results we shall repeat the errors of the past. The architects and builders who perpetrated the monstrosities of the seventies and eighties 
did not seek deliberately to inflict a blight upon the American landscape; but they lacked standards and discrimination. The man who opens a shop in a residence neighborhood is apt to believe that his shop is a good thing, no matter where it is, and certainly that the city is a good city in so far as it allows its citizens great liberty of action in the use of their property. He does not see and understand the harm which such complete liberty of action involves.

No amount of diffusion of information and direction of attention will reach all citizens; but with a well-defined public opinion based on standards of excellence and high self-respect, it is possible to bring about civic achievements of great magnitude.

Qfficial Plan Commissions.-While much may be accomplished by the unofficial citizens' plan committee, there is a growing demand for the creation of official plan commissions as an integral part of the municipal government. Some very excellent plans have gone into the discard because they never became official, either in whole or in part.

The weight of authority, according to Frederick Law Olmsted, is in favor of a permanent, central, co-ordinating plan commission, free from the bias of special interest in any one particular kind of improvement and free from the overwhelming pressure of the routine work of construction and administration.

A common method for securing the application of the city plan has been for the official planning commission to take up and have adopted by the appropriate municipal authorities the different features of the complete plan, project by project. This has been the Chicago procedure. The Chicago Plan Commission, created in 1909, consists of 328 members, appointed by the Mayor on approval of the City Council; the ex officio members change with terms of office, the terms of the citizen members are indefinite and they serve without pay. A professional city planner is employed on a retainer fee. A staff of seven is employed in addition to the planner's staff of six. 
The executive officer is a manager. According to the official report fourteen major features were going forward simultaneously during the year 1925 at a total cost of some $\$ 350,000,000$.

Cincinnati is said to be the first city to adopt a complete and comprehensive plan. The City Planning Commission, created in I9r8, consisted of seven members, five ex officio, consisting of Mayor, three from Board of Park Commissioners, and the Service Director, two appointed by Mayor for six-year terms to serve without pay. In the preparation of the plan a city planning consultant was employed on a basis of fixed charge. The City-Manager form of government has since been adopted.

The recent tendency has been to create planning commissions of five, seven or nine members, though a few consist of fourteen or fifteen members. In Los Angeles the Commission created in 1920 was very large. The new charter, effective in July of 1925, provides for a Commission of five members appointed by the Mayor for five-year terms, overlapping, paid by day with a professional city planning consultant employed for full time and a staff of ten. The executive officer is designated as a director.

On most of the plan commissions the citizen members give voluntary service and the ex officio members receive no additional remuneration. In the larger cities a resident city planning consultant is employed. In the smaller towns, a consultant who visits the town at intervals is frequently employed on the fee basis.

In addition to keeping watch over the city plan, whether it is official or unofficial, and presenting definite projects to the appropriate municipal officials, the city plan commission uswally has charge of the platting of new subdivisions. The comprehensive plan in general covers the arterial street system and basic control in outlying areas, but the intimate planning of public and private property as it comes into use is usually reserved until its occupation is imminent. On the platting 
of new subdivisions a city planning commission should do much more than approve or disapprove of proposed layouts. Here is where the value of expert planning advice can be proven. It the layouts which owners of property bring into the commission are not good, there should be a city planning expert who could show these owners how they could lay out their land to the benefit of the community, the future owners, and the appearance and usefulness of the property. Often constructive suggestions may bring better financial returns to the owners than the conventional plats which they are apt to bring in for approval.

A case in point is that of an owner in a Middle West city who brought in a plat of a proposed subdivision on gently rolling land cut by a winding stream. He expected to fill in the stream at great expense. He laid out his lots $25 \times 200$ feet because the blocks were deep and he thought he must make narrow lots in order to sell them at a price to cover his initial cost, the installation of utilities and a reasonable profit. He consented to substitute the layout of the plan commission which preserved the stream as a parkway and laid out the streets with the contours to give wider and shallower lots of different shapes. Much to the owner's surprise he found that the lots facing on the parkway which he had considered of least value brought much higher prices than any of the others. The value of the land which he relinquished for the parkway was more than offset by the additional compensation from the lots sold for residences. Such service is an important function of a planning commission.

Zoning Commissions and Boards of Appeals.-When a city passes a zoning ordinance it is customary to provide for a Zoning Commission or to designate the City Planning Commission to supervise the classification of the land and the preparation of the use, height and area maps. When there is a special Zoning Commission it sometimes passes out of existence when the classification of land is adopted by the legislative body. In other cases it continues to function. 
Under most zoning ordinances the City Council must pass upon original classifications and changes in classifications. In addition to this, most zoning experts advocate the creation of a Board of Appeals to pass on special cases where the literal application of the law might be thought to work a hardship and where the decision of the Zoning Commission or City Council is called in question by the property owner. Where satisfactory Boards of Appeals have been established the number of court cases have usually been greatly reduced in case the Board of Appeals was established after the zoning law had been in effect. The Board of Appeals is considered a very effective safety valve.

A case in point was that of an owner who desired to build a theatre on a shallow lot with no alley intersection to reach from one street to another. But one street was zoned to be commercial and the other residential, with a difference in the height of buildings permitted. The Board of Appeals permitted the erection of the theatre on condition that no entrance or egress should be permitted on the residence street, that the height limitation on the residence street should be enforced and that certain architectural features should be included in order to preserve the residence appearance. On the commercial street the building was permitted to reach the more liberal height designated. The owner accepted the decision and did not take his case to the courts as he probably would have done had there been no Board of Appeals authorized to make such an exception in the application of the ordinance.

Concerning the personnel of the Board of Appeals the most important qualification is that the members have practical knowledge of construction methods and land uses. A publicspirited architect, contractor, or engineer is most desirable on a Board of Appeals.

Municipal Art Commissions or Juries.-Another commission, with special functions, which has rendered valuable service in many cities, and which is much needed in others, is the Municipal Art Commission or Jury. These commissions 
pass upon the designs of all public buildings and monuments and sometimes upon park designs when there is no city plan.

The Municipal Art Commission of Baltimore was one of the first created. The New York Art Commission also dates back to 1898 and consists of ten members, ex officio members being the Mayor, the President of the Metropolitan Museum, the President of the Public Library, the President of the Brooklyn Institute of Arts and Sciences, with six citizen members appointed by the Mayor from lists submitted by the Fine Arts Federation of New York City. The citizen members serve for terms of three years and give voluntary service.

The Art Commission of Pittsburgh, created in rgr $r$, consists of nine members, five professional, appointed by the Mayor for four-year terms. The Commission employs a paid executive secretary and is "unique in being authorized to prepare and recommend schemes for adoption by City Council. It also has veto power on 'works of art,' public buildings and bridges costing over $\$ 25,000$ and $\$ 50,000$ respectively."

Portland, Oregon, has an Art Commission, created in I923, consisting of nine members appointed by the Mayor for fouryear terms, overlapping. The members give voluntary service.

In cities where no art commission existed at the time of the creation of the city planning commission the planning body has frequently been charged with the duties of passing on the design of public buildings and bridges.

In Washington the Fine Arts Commission, created in r9ro, consists of seven members appointed by the President of the United States to serve for a term of four years. In practice there is usually an architect, a landscape architect, a sculptor and a painter on the Commission. The act provides that the Commission of Fine Arts shall "advise upon the location of statues, fountains, and monuments in public squares, streets, and parks in the District of Columbia, and upon the selection of models for statues, fountains, and monuments erected under the authority of the United States and upon the selection of artists for the execution of the same. The Capitol and the 
Library of Congress were specifically excluded, but the Commission was directed to advise generally upon questions of art when required to do so by the President, or by any committee of either House of Congress. In practice the advice of the Commission has been sought generally on the location and design of public buildings through the executive orders of successive Presidents.

City Park Commissions or Departments.-Park Commissions have played a very important part in the early development of the city planning movement. Many park commissions were established in the closing years of the nineteenth century and the opening years of the twentieth century, but when the demand for a centralized responsible municipal administration brought forth the city manager and similar movements, park commissions were frequently replaced by park departments, with a superintendent or director directly responsible to the central executive. For administrative purposes and in the interest of executive control of the budget this has generally proved a good arrangement. On the whole, however, the park extensions necessary to keep pace with the growing population seem to have suffered somewhat when there was no body of public-spirited citizens to keep the matter agitated. In some degree city planning commissions have supplied this push, but plan commissions have many other duties and though they may designate areas appropriate for park development they cannot always supply the initiative and push needed to bring about the acquirement of the land at the proper period. There is much to be said for park commissions when it comes to adequate park and playground extensions.

In Washington, D. C., the recently-created National Capital Park and Planning Commission, consisting of seven ex officio members and four eminent citizens appointed by the President, is charged with the duty of acquiring the parks and playgrounds for the District of Columbia and with co-operating with the adjoining States of Maryland and Virginia to estab- 
lish parks and parkways in the surrounding territory. In general the areas recommended for purchase by the Senate Park Commission of r 90 r furnish the plan for immediate application. But the parks of the District of Columbia are administered by the Director of Public Buildings and Public Parks under the law of 1925 . This office is co-ordinated with the National Capital Park and Planning Commission through the fact that the Director of the office is also executive officer of the commission. But the significant feature of the arrangement is that the administration of the parks is placed in an office with a single head and the acquirement of additional park and playground areas is made the duty of a separate commission.

The administration of playgrounds is sometimes placed in the park department, sometimes in the school department and variously under departments of health, recreation departments, public welfare divisions and occasionally under separate playground commissions. In smaller places the playgrounds are occasionally administered directly by the town commissioners.

But the location of playgrounds as well as parks is a definite function of the planning commission. Municipal departments may administer parks and playgrounds, special commissions may acquire open spaces; but it should be the duty of the planning commission to co-ordinate their location with other features of the city plan.

Regional Plan Commissions.-Regional planning is of more recent date than the planning of cities within their established limits. Therefore, we find regional planning is still in many places in the hands of citizen bodies not yet made official. More frequently regional planning is altogether neglected. But the trend of the development is towards regional or metropolitan planning.

The Regional Plan Commissions thus far established have quite different jurisdiction and personnel from the official city plan commissions. Dr. Thomas H. Reed of the University 
of Michigan has classified existing regional or metropolitan planning authorities:

(I) Those where the authority is appointed by the central government. (By the States in this country.)

(2) Those where it is selected by the governing bodies of the various units of local government.

(3) Those where it is elected by the direct vote of the people of the area affected.

(4) Those where it is made up, in whole or in part, of representatives of the various interests most nearly affected by its activities.

But it is admitted that the governmental organization to be provided for a region is still subject to experiment.

Planning in the Boston region is now in the hands of the Division of Metropolitan Planning, created in May of 1923. The division consists of seven members, three appointed by the Governor, four ex officio from existing Boards, for fiveyear terms of overlapping voluntary service.

Regional planning for the New York City area is being carried on largely by the Committee on Regional Plan for the City of New York and its Environs set up by the Russell Sage Foundation. This is supplemented by the State Housing and Planning Commission.

A definite movement toward the planning of the Niagara Frontier has been initiated through the Niagara Frontier Planning Committee, consisting of thirteen members including the mayors of six cities-Buffalo, Niagara Falls, Lockport, North Tonawanda, Tonawanda and Lackawanna-or persons especially designated by them, and six supervisors, three appointed by each Board of Supervisors of the Counties of Niagara and Erie, these twelve to meet and select a thirteenth member who will act as chairman.

The planning for the Los Angeles region is carried on by the County Regional Plan Commission, created in June, I923, and consisting of five members appointed by the Board of Supervisors of the county for three-year terms of overlapping, voluntary service. 
Saint Paul, Minnesota, has a Regional Plan Commission, created January Io, 1924, consisting of fifteen members selected by existing organizations.

The Regional Plan Commission of Toledo, Ohio, was created in April of 1924 and consists of eleven members, eight citizen members and three County Commissioners.

In New Orleans the City Planning Commission created by the City Council in May of 1923 has authority to make a regional plan.

In Albany, New York, a Regional Plan Commission of the Capital District was created in 1925.

State Enabling Acts.-There are various sorts of State enabling acts and constitutional amendments. In many instances a State law sets up the authorization for the creation of a planning body and defines its powers for a specific single city. In others there is a general enabling act. Frequently the charter of a city sets up the planning authority and defines its powers and this is through the delegation of power from the State either in a specific law applicable to a single city or, through a general law granting certain powers of local selfgovernment.

The right of the municipality to exercise the powers of zoning has so frequently been called into question by the courts that the Division of Building and Housing of the Department of Commerce, through an advisory committee, has issued a Standard State Zoning Enabling Act. Many of the adverse decisions against zoning have been due to the opinion of the court that the municipality lacked the right to zone. The adoption of a good State zoning enabling act would eliminate this difficulty.

Definite Program.- - In the history of city planning in the United States plan commissions have been created which did not function. Adequate appropriations are necessary. In order to secure sufficient funds for the employment of technical advice to survey the city and prepare a comprehensive plan, a careful program of procedure should be drawn up, supported by an estimate of the time and money required. In general 
plan commissions are composed of busy ex officio officials who have pressing administrative duties and of equally busy citizens who give voluntary service to attend meetings of the commission. Such commissions are excellent policy-making bodies and serve as a link between the men who make the technical recommendations and the citizens. But such a commission cannot conduct a businesslike survey and prepare a scientific comprehensive plan without technical advice and consecutive technical assistance. It is most important, therefore, that a program of procedure be adopted at the outset if the plan commission is to function effectively and produce a plan which is worthy of the name.

Preparation of the Comprehensive Plan.-If the technical staff called in to prepare the comprehensive city plan fails to produce a scientific plan the machinery set up is wasted. Here are required wide and deep technical training in several professional fields. Here are needed long-range vision and close-range judgment. It is by the technical staff that the survey will be made.

City Planning Surveys.-The first essential in any city planning survey is to secure adequate maps. Occasionally these are available when the city planner arrives on the ground. More often they are lacking and must be supplied. Professor W. M. Davis of Harvard University has emphasized the importance of maps which show, not only the topography, but the location of railways and highways, the placing of public utilities and all existing physical features. As applied to city planning Frederick Law Olmsted has outlined the need for proper maps. He thought that there should be secured an accurate framework of reference points, including:

"(I) the gradual systematic setting of street monuments throughout the city to serve as reference points for the definite determination of street locations and for all public and private local surveys; (2) the accurate determination of the locations and elevations of these and other monuments and bench marks in reference to a single general system of co-ordinates and in reference to 


\section{LAND PLANNING IN THE UNITED STATES}

the United States Government bench marks; and (3) as a means of accomplishing these ends an accurate geodetic triangulation of the district, supplemented by the necessary precise traverse work and precise leveling all fully checked and compensated for errors."

Attention was called to the early inaccuracies in the surveys of land in the United States, especially during the Colonial and early National periods. Probably few people realize how little of the area of the country has been mapped accurately in regard to position and elevation. We have been delinquent in the establishment of permanent monuments and the actual measurements are frequently at fault. It is said that in Pittsburgh, many years ago, "a measuring bar was used in city survey work which was later found to be too long. This bar was made a legal standard for its nominal length, so that now in some lot surveys a tape nominally roo feet in length must have a standard length of Ioo.I feet."

The map of the United States which shows the progress of the geodetic maps indicates that vast areas are yet to be covered. Few cities have adequate topographic maps. It is probable that many city engineers are not aware of the fact that a comparatively small local appropriation and an application to the United States Government would make possible in due course the preparation of accurate position or geodetic maps and elevation or topographical maps. The accurate topographical map is dependent on the geodetic survey. Accurate geodetic control is also of great value in underground mapping, and "the underground survey is essential to the proper extension of the city plan." For road surveys, for land subdivisions, for the connection of detached land surveys and for harbor surveys the basic geodetic and the accurate topographical maps are exceedingly important.

Thomas Adams has specified that the first step in the City Plan survey is the collection of copies of existing maps. $\mathrm{He}$ particularly recommends the Federal maps on a scale of one inch to one mile for the city and surrounding region. On a second map on a scale of 1000 to 2000 feet per inch he suggests 
that the main street and highway systems, waterways, railways and other broad features in the development of the area should be drawn. He recommends a map on a scale of from 200 to 400 feet to the inch for showing buildings and topography within the city. Mr. Adams believes that the topographical map should be supplemented by an aerial map, but he adds a caution that "the aerial mosaic should not, of course, be relied upon for accuracy of measurement."

Twenty years ago rather sketchy information was secured before a new park plan was proposed or a modified street system recommended. To-day there are some planners who gather so many statistics that they sometimes find themselves confused in the maze. Mr. Adams recommends a middle course, suggesting that problems of railway transportation and termini, the main highway system, street traffic, sewerage and water supply, distribution of power and light be covered by an engineer of experience; that questions of finance, assessment, land values and legal problems might need an economist or attorney; that the general physical layout of the city, the park and recreation system be placed in the hands of a landscape architect; and the civic center and control of building development in the hands of an architect.

In a recent planning survey of the City of Cincinnati by the Technical Advisory Corporation all the data gathered were indicated on a single map through the use of colors and symbols. The sections of this map were in such constant demand by the various city officials that the map was almost worn out by the time the report was adopted. In other words, entirely apart from the preparation of the Plan, the information gathered and put in graphic form was of repeated service to existing city departments in the transaction of ordinary municipal business.

In the preliminary survey of Worcester, Massachusetts, the Technical Advisory Corporation drew up a syllabus for items to be considered which might be applied to almost any city in the United States. The various elements were examined in 
their possible relation to a Comprehensive City Plan. The outline follows:

\section{Public Service}

Substructures-suitability of sewers, pipes and conduits.

Water Supply-present source and system of supply, adequacy for present and future needs.

Sewage disposal-character and adequacy of system.

Dirt, Waste and Snow Disposal-street cleanliness; collection and disposal of garbage, ashes and refuse; present methods and possible improvements.

Food Supply-sources and adequacy; markets; distribution.

\section{Circulation}

Street Traffic-vehicular and pedestrian; street congestion and possible relief; street accidents and their minimization; police regulation and direction; public conveyances; one-way streets; sidewalk encroachments.

Thoroughfares and Minor Streets-straightening, extending and widening. New arteries of travel. Minor streets and alleys; paving and condition.

Street Design and Construction-paving policies; construction and repair methods employed; new construction.

Motor Vehicles-quantity and kinds; regulations; parking and storage; garages; effects in and on streets; relief possible; restrictions.

Street Furniture and Facilities-tree planting; poles and wires; hydrants; kiosks; signs; comfort stations; effect, adequacy and improvement.

Transit Lines-rates of fare; service rendered; present facilities; adequacy or inadequacy; extensions and improvements; new routes or rerouting.

Railways-present service and facilities; present and future needs; passenger and freight terminals and yards; terminal warehouses; grade crossings and their effects; grade crossing elimination; improved service; rerouting; viaducts; bridges.

\section{Civic Improvements}

Public Buildings-present municipal buildings; locations, suitability and adequacy; provisions for locations for new public buildings (and approaches thereto) including libraries, schools, hospitals, museums, churches, institutions and administration buildings; future civic center. 
Civic Art-monuments, statues, ornamental poles and fixtures; location, appearance, provisions for future.

\section{RECREATION}

Playgrounds and Recreational Facilities-locations, suitability and adequacy of present facilities; future needs and locations; control and direction of recreation.

Parks, Parkways and Esplanades-present facilities, their use and adequacy; future needs; provision for new parks, approaches and connections; co-ordination in comprehensive plan.

\section{Municipal Control and Protection to Private Property}

Building Districts and Restrictions-present laws relating to buildings and their uses; building lines; heights and uses of buildings, courts and yards; injuries done as a result of unrestricted building operations; need and probable benefits of zoning.

Fire Control-present fire limits and advisable extension; adequacy of fire fighting facilities; future needs; provision for locating future fire houses; control over explosives and combustibles.

Garages and Filling Stations-location and their nuisance character; control under zoning ordinance.

Billboards and Signs-present locations and control; nuisance character; future control.

Smoke and Fumes-extent of abuse and possibility of limiting and controlling in future.

Sanitation and Health-present conditions and ordinances; possibilities for improvement.

New Plats-Additions-Subdivisions-method of control over private developments; co-ordination with city streets; future regulation and control.

Cemeteries-Aviation Fields-present facilities; provision for future.

\section{Finance and Administration}

Paying for Improvements-assessment methods; city debt limit and indebtedness; tax rates; sinking funds; budgets; means of financing plans for future improvements.

Administrative Methods-present methods and effect. Future possibilities.

Mr. Thomas Adams presents a slightly different outline which is well worth careful study and for purposes of suggestion is here quoted: 


\section{Existing Organization and Available Data}

(I) Local Government. State laws in relation to city planning, building codes, etc.; provisions of city charter; existing ordinances governing fire, building construction, streets, etc.; continuity of administration of council or commissions.

(2) Reports of Previous Surveys and Other Data Available. Surveys of social or industrial conditions; statistics of population at different periods; tax rate; financial conditions.

(3) Maps. Maps of city engineer; railway maps; street railway maps; small scale topographical map of region; blue prints of recorded subdivisions not shown on city maps; underwriters' maps showing buildings.

\section{Fundamental Elements in City Growth}

(I) Land System. Original forms of ownership and division plans of land; influences of original plans on city subdivisions; typical lot and block dimensions; effect of lot or block sizes on character of dwellings and business premises erected; effect of land speculation on values; what relation the values have to value of improvements; community created values; system of assessment and taxation; assessment for benefits; methods of apportioning cost of local improvements; wherein there is need for better method of assessment and taxation and control of land to promote economic use; relations between city and country districts; regional problems.

(2) Industrial Growth. History of industrial growth within the region and particularly within the city; its origins; influences that have promoted or retarded growth of industries; location and distribution of manufacturing plants and wholesale warehouses; opportunities available for future development.

(3) Homes. The character of the homes; local types of dwellings; psychclogy of people; educational opportunities; existing sanitary arrangements; evidence of healthy or unhealthy conditions; vital statistics, etc.; directions in which improvement of surroundings and general housing conditions can be made.

\section{Physical Plan and Public Services}

(I) Means of Communication and Distribution.

(a) Railroads and their termini; electric railways; problems of railways in streets; grade crossings; street approaches to stations; statistics of local passenger and freight traffic; facilities for transit between homes and places of employment; position of markets. 
(b) Highways and Streets. General street plan; arterial highways and major and minor streets; widths and laws governing them; how adapted to configuration of land and needs of traffic; relation of widths to height and bulk of buildings; grades; proposed widenings, openings or extensions; traffic circulation; street system and fire prevention; trolley lines in streets and sidewalks; points of collision and areas of congestion; traffic regulation; extent of permanent pavements and sidewalks.

(c) Waterways, Docks and Ferries. Connections with railroads; street approaches.

(2) Power Supply. Sources and distribution; facilities for extension.

(3) Building Development. General distribution of buildings; residence, business and industrial areas; sizes of lots in relation to type and character of buildings; alleys and how used; private restrictions; tendencies in regard to character of dwellings-detached, semi-detached, two deckers, rows or tenements; building on rear yards; typical widths of frontages; position of public garages and oil filling stations; relation of building ordinances to city planning ordinances.

(4) Water Supply and Sewerage. Extent of building area served; vacant lots served; source of water supply; pressure for fire purposes; separate or combined system of sewerage; sewage disposal; stream pollution.

(5) Civic Art. Placing of public buildings; need of grouping public buildings and control of surroundings; street approaches; relation to street system; convenience of location.

(6) Parks, Public Recreation and General Amenities. Shade trees in streets; policy of planting; areas of parks, etc., in relation to population; children's playgrounds; rural park system; connecting boulevards; use of parks; management of park system; encouragement of athletics; accessibility; indoor facilities for recreation; private parks; garbage dumps; protection of water fronts; location of cemeteries.

(7) Educational and Other Quasi-public Buildings. Location of schools; school playgrounds; social centers, hospital sites.

One caution Mr. Adams presents. He believes that the survey should not be too elaborate, that "a mistake can be made by aiming to make too complete an analysis of a city just as well as by omitting essential investigation." "The 
successful planner is the one who knows what to eliminate as well as what to include."

Perhaps the most obvious omission from many of the surveys, reflected in the personnel, has come from the neglect of the trained economist. Studies of trends of land values, analyses of the causes for increase and decline of values; estimates of costs of projects and probable effects on values, often would lead to decisions far different from those which have been made in happy ignorance of such related facts. The study of economic values frequently reveals social standards. Almost always co-ordinated social and economic surveys would shed illuminating influences on the other technical data.

It must be clear that in the making of surveys, as in most other technical undertakings, no hard and fast rule can be laid down. The experienced planner must select the field of investigation to fit the needs of the town or area. There are some facts which can be brought to light only through exhaustive search. There are other facts which are apparent at once to the trained observer. The preliminary observation, then, will influence the direction and emphasis of the survey in each particular instance.

Personnel.-In the early days of city planning in the United States a landscape architect or a social worker who had become convinced of the need for better living conditions would visit a city at the request of a club or civic organization and make a survey of the conditions. There were the park surveys and the housing surveys. Frequently the surveyors hardly realized that they were approaching the same problem from different directions. The architect or the landscape man who made suggestions for "beautifying" a town was often held in contempt by the social worker who was exposing iniquitous slums and unsanitary tenements. We also passed through a period of sanitary surveys made by laymen to show the needs. The engineers came with the actual project for water supply or sewerage systems. 
To-day it is well understood that the field of city planning covers half a dozen or more technical professions. The city planner must have a working knowledge of engineering, architecture, landscape art, housing and building codes, land management and social needs. This is needed for the general comprehension of the subject. Most city planners, however, like most general practitioners of medicine, call in the expert or specialist for the diagnosis of acute problems.

During the war the United States Housing Corporation adopted a procedure which took into account the need for cooperation between the technical professions. When an application was made for the housing of war workers a preliminary survey was made by someone with a general knowledge of city planning and social conditions. If this survey disclosed the probable need for housing a team of four was sent into the field for definite recommendations. This team consisted of an architect, a landscape architect, an engineer and a "realtor." Frequently some one of these four had special training in social observation and the application of social remedies.

The social point of view and the knowledge of the technique of social work is so important, however, that it is the belief of many that the only safe way to make sure of a proper emphasis on the social needs of a community is to include in such a survey team a trained social worker. The inclusion of someone who has a practical working knowledge of the management of land is sometimes overlooked. This is not remarkable when one considers that the real estate business has hardly yet been freed from the irresponsible speculative basis. Fortunately leaders have recognized the need for the adoption of standards. The recently established courses in land economics in several of our larger universities and the creation of the Institute for Research in Land Economics and Public Utilities will provide sound training for an increasing number of men and women who expect to engage in the real estate business. The land economist with practical knowledge will be able to make a larger contribution to city planning than the so-called 
practical business man who is frequently more influenced by the opportunities for immediate gain than by the more remote welfare of the community.

In the forming of these teams by the United States Housing Corporation there was some discussion as to which profession was best adapted to furnish chairmen of the teams. Sometimes it was the landscape architect who had most experience in general city planning. Sometimes it was the architect, sometimes the engineer. Occasionally the practical real estate man acted as chairman. Judged by the results, the profession of the chairman appeared to be of little consequence. Breadth of vision and leadership seemed to be important qualifications.

An analysis of the important city planning offices in the country to-day will disclose the fact that the technical workers are grouped sometimes around a city planner with social training, sometimes around a landscape architect who has acquired city planning experience; sometimes around an engineer; occasionally around an architect. In the nineties and even in the first few years of the twentieth century the architects took a leading part in the development of city planning. At present the interest is less manifest though architecture touches city planning at many points. Twenty years ago when city planning was focused around civic centers and public buildings it was natural that the architects should bear a large part. It is perhaps natural that the traffic requirements of large cities should have given city planning a direction which has involved the engineers more generally.

Because the emphasis falls in different decades on special problems we are not relieved from the need to meet all the problems of comprehensive city planning. Therefore we should profit by the expert advice of six or seven professions in any city plan and usually the engineering problems alone require several specialists in that field.

The building of modern populous communities is far too complicated to depend upon any one individual or any one profession for its working plans. 
Public Education.-Contrary to the popular impression, the need for public education does not cease with the preparation of the plan. Plans are made for centuries. The oncoming generations must be kept informed. The active understanding and co-operation of the community is essential if great plans are to be achieved. Public buildings in Washington are being located to-day according to a comprehensive plan drawn over I 35 years ago. If it were not for an informed public opinion it would be impossible to conform to the L'Enfant Plan.

Continuous application of the city plan is highly important. The broad lines of the long-range view will have been laid down in the comprehensive plan. Detailed projects must be prepared from time to time. These should be reconciled with the master plan. Every year public improvements will be under construction. Public works should conform to the plan. Indeed, the executive officer or planning engineer of the Plan Commission should keep in touch with all of the public officials responsible for public works. In a growing city there should never be a time when a great deal of important work should not be needed from the Plan Commission.

\section{SUGGESTED READING}

John NoLen, The Importance of Citizens' Committees in Securing Public Support for a City Planning Program. National Conference on City Planning, I924.

Frederic A. Delano, Harland Bartholomew, George B. Ford, Lawson Purdy and Harlean James, City Planning Procedure, American Civic Association Bulletin, January, 1926.

Amertcan Crvic Association Bulletin, Municipal Planning, Park and Art Administration in American Cities, May I, 1925.

E. Lester Jones, Report on Use of Mean Sea Level as the Datum for Elevations, U. S. Coast and Geodetic Survey, 1917.

Hugh C. Mrtchell, Use of Geodetic Control for City Surveys. Special Publication No. 9I, Serial No. 216, Department of Commerce, U. S. Coast and Geodetic Survey, 1923.

Thomas Adams, Modern City Planning, supplement to the National Municipal Review, June, 1922. 


\section{LAND PLANNING IN THE UNITED STATES}

\section{NOTES}

Page 276. Frederick Law Olmsted has prepared a statement on the Fundamentals of City Planning which might well stand as a guide.

"Experience has shown that to secure reasonably far-sighted initiative and reasonable co-ordination in planning streets, transportation and other utilities, together with parks, public building sites, zoning regulation of private property and other elements of an entire (or comprehensive) city plan, these four things are fundamental:

FIRST: A permanent, central, co-ordinated agency, free from the bias of special interest in any one particular kind of improvement and free from the overwhelming pressure of the routine work of construction and administration.

SEcond: The close relationship of such a planning agency with the principal agencies responsible for decisions in the several branches of executive work concerned; such relations being established by representation on the directorate of the general planning agency or otherwise.

THIRD: Inclusions in the planning agencies of technically competent persons, unbiased by connection with specialized executive agencies.

FouRTH: Sufficient funds for those investigations and (varieties of) planning which are not obtainable through the collaborating executive agencies and sufficient time for getting at the roots of the troubles and for adjusting inevitable local conflicts of opinion and interest.

"To secure large results, planning in the sense of securing the adoption of and adhesion to well co-ordinated plans for all special and local needs, must be a perpetual and administrative process. One year's work by a special commission can be nothing but one step in that process and the most useful thing a commission could do in one year would be to produce a general analysis of the problems as they appear and practical recommendations for the most promising means for carrying on the continuous process of solving them, intelligently and economically, in the public interest."

Page 286. "The map resulting from that (underground) survey should show on a scale sufficiently large to avoid confusion all structures existing under streets and open city property and all public service and underground structures no matter where located. This will include subways, tunnels, sewers, water pipes, gas mains, and telephone, telegraph and electric-light conduits. In a built-up section of a city this information is necessary for the proper maintenance of the streets and of the underground structures themselves, and in partly built-up areas the information is necessary for planning extensions. If geodetic horizontal control has been established over a city in connection with 
the topographical and cadastral surveys, it can be used also for the underground survey and the one control, if properly planned and executed, will thus serve all three detail surveys. The same is true in regard to the vertical control." It may be explained that the cadastral survey consists of two parts-the surveying and mapping of the territory and the official valuing of the land for governmental purposes. The surveying and mapping of the land is of special importance in city planning. From the Special Publication on the Use of Geodetic Control for City Surveys, by Hugh C. Mitchell.

Page 287. Concerning the survey Thomas Adams presents a plan of procedure: "It is essential to have clearly in mind the maximum use to which the knowledge collected can be put. The amount of money available will to some extent influence the character and scope of the survey. The following are among the points which should be borne in mind in approaching the survey:

"(I) The first question is the selection of the territory to be surveyed and planned. Where it is practicable under the law to ignore arbitrary municipal boundary, careful attention should be given to the selection of the regional area. ...

"(2) In planning physical alterations within the territory, a constant balance has to be kept up between what are called the interests of the community and the interests of the individual.

"(3) Different problems should be dealt with by specialists in each problem, a group of four specialists being desirable in ordinary casesone dealing with railroad transportation and termini, the main highway system, street traffic, sewerage and water supply, distribution of power and light and other engineering problems; a second with the question of finance, particularly in relation to assessment and land values, and legal problems; a third with the general physical layout of the city, the park and recreation system, and a fourth the civic centre, and the control of building development. This group will usually include an engineer, a lawyer, a landscape architect and an architect.

"The lawyer will not be a planner but a consulting member of the group. The other three will be responsible for the plan. One of the three should co-ordinate the work of all. The width and complexity of the field to be covered requires that at least three should be employed in the larger cities. One expert with the aid of competent local officials will suffice in the smaller cities and in towns. Care has to be taken not to endanger the plan by too much specialization and consequent lack of co-ordination.

"(4) The plan should have the effect of encouraging rather than restricting growth. It must be elastic and capable of modification 


\section{LAND PLANNING IN THE UNITED STATES}

but only under conditions based on principles and not on local expediency. Even slight changes may cause injustice and should only be made with the aid of expert advice."

For the showing of special data on the large-scale map Mr. Adams suggests that perhaps a dozen copies be secured from a tracing, and the following colored cartoons prepared.

Transportation map, showing existing railways, stations, waterways and harbors, markets, etc.

Street services map, showing existing street railways and proposed extensions, water mains, sewers, power lines and different kinds of street pavement.

Street traffic map, showing main arteries and focal points, level crossings, street railway intersections, street collision points and (if census be taken of traffic) number of points with reference to figures in report. On this map lines should be drawn in color showing areas within a quarter of a mile of any street railway.

Land valuation map, showing the assessed values of land in blocks at the different values per square foot or per front foot. Thus blocks $\$ 5$ to $\$ 10$ per square foot or $\$ 500$ to $\$ 1000$ per foot frontage would be shown in one color and at $\$ 1$ to $\$ 5$ per square foot or $\$ 100$ to $\$ 500$ per foot frontage in another color.

Existing conditions map, showing the industrial, business and residential areas, parks and parkways, and sites of public and quasi-public buildings.

By careful presentation with a prearranged notation of colors and marking the transportation, land valuation and existing conditions map may be combined as one "existing conditions" map. 


\section{THE COST OF CITY PLANNING}

Cost of the Plan.-The amount of money which is required to prepare a comprehensive city plan is dependent upon so many factors that it is difficult to generalize. The making of proper topographical and other maps is not only an item of expense but requires considerable time if adequate maps are not already available. The size of the area covered and the complications of congested traffic and haphazard development may influence the cost. A hundred thousand dollars might be required to make a complete survey and prepare a comprehensive plan with specifications for projects to be carried out promptly in a city or region of a million or more inhabitants. The unofficial Regional Plan Committee for New York and its Environs is spending upwards of half a million dollars and will probably need more. For small cities the cost would be proportionately less.

The difficulty in estimating the cost of making a plan lies in the fact that a comprehensive plan comprises so much more than the sum of numerous detailed studies and as many proposed remedies. The cost of making a preliminary survey, gathering specific data, and preparing drawings in the drafting room can be counted. But the advice of a small man with a small vision may be worth little for a town of any size and the advice of a planner who can penetrate the future and see wide visions may be worth a great deal of money, for upon the difference in planning advice may depend the future of the town-just the difference between a good town and a poor town.

Not every engineer, architect, landscape designer or city 
planner has the capacity or training for long-range comprehensive planning. With professional planners of experience and ability in charge of the work, the initial cost may exceed the sum required for relegating the job to over-worked public officials who seldom have the time or the special training for preparing great plans.

In the long run the cost of preparing a comprehensive plan is not really important. At least it may amount to a few thousand dollars. At most it will seldom exceed a hundred thousand dollars. The really important factor is the cost of not preparing such a plan. Millions of dollars are wasted in this country annually by the erection of homes and buildings which will be replaced long before they "wear out," because they are put in locations where they cannot survive the outward push of business, even under fairly intelligent zoning laws. Other millions are required to widen streets to carry the heavy streams of traffic along arterial thoroughfares. Probably billions of dollars' wor ih of time and equipment have been confiscated in the delays of acute congestion in our crowded centers since the advent of the automobile.

Vast sums of money are spent annually in the United States in public improvements. Unless we have comprehensive, as well as specific, planning there is great waste. So far from estimating the cost of making the city plan, our communities should be busy figuring the great savings which they will effect by intelligent planning based on sound technical advice.

Some of the early plans of cities were laid aside when the members of the city councils figured out what it would cost to put into effect all the recommendations of the city planners. Properly speaking the projects carried out under the city plan are seldom, if ever, directly chargeable to the plan. It is true that some cities have spent enormous sums to cut through boulevards or main thoroughfares in built-up sections, but if any part of these costs came out of the general taxes it should be charged to the neglect of city planning in the past. The $\$ 80,000,000$ bond issue of Saint Louis was not for the 
city plan. It was for projects which in some form or other were bound to be carried out if the city expected to keep abreast of the times. The whole question was as to whether the money spent was to be for projects in conformity with a city plan in order that there might be no waste in making false starts and consequent correction of errors, or whether a large part of the money was to be wasted through ill-considered haphazard improvements which might become obsolete in a few years.

The Cost of Specific Projects.-It cannot be denied, however, that such projects as parks, parkways, streets and their utilities, bridges, water front developments, and public buildings do cost money. There ought not to be added to the actual cost an additional charge due to failure to conform to a plan.

The financing of city planning projects falls quite naturally into two classes:

I. Those projects which properly can be charged against the general taxation of a city or local government.

2. Those projects which properly can be charged, in whole or in part, against abutting property or benefited areas.

The costs of both sorts of improvements may be spread over a period of years by bond issues, serial certificates or successive annual appropriations. The test as to whether an undue cost is being laid on the future lies in a reasonable estimate of the life of the improvement and the provision for upkeep and repairs. A thirty-year bond issue to pay for the pavement of a street which will not last over fifteen years and will need repeated and expensive repairs due to its probable future use could hardly be justified. A twenty, thirty or fortyyear bond issue to secure large undeveloped areas for park purposes to serve a growing population could be justified even though the cost of the improvements might exceed greatly the original cost of the land. The life of such an improvement 


\section{LAND PLANNING IN THE UNITED STATES}

is almost indefinite. Presumably the purchase price of such outlying land would be appreciably lower than in later years when its intensive use would be more imminent, though it is conceivable that on this ground alone the purchase might not be an economic investment. The interest on the money invested and the loss of taxes over a very long period of time might more than equal the increase in the value of the land. A more important element is the securing for the future city of exactly the right areas for park development before the land is occupied for other purposes and before the character of the surrounding land is determined by its owners. Just as in any private business, it is desirable to weigh all of these counterbalancing conditions and tendencies and to make purchases at the right time.

Projects Charged Against General Taxation.-We find the costs of public buildings generally, whether concentrated in a civic center or distributed in different parts of town, are charges on general taxation. The costs of schools and libraries, even though they are built to serve specific neighborhoods, are usually covered by bond issues on the theory that the entire public purchases the entire school or library property and that in the long run the distribution of buildings will serve the population more or less equally.

The cost of bridges to provide main entrances and exits or to make connections in arterial thoroughfares would ordinarily be met by bond issues paid from general taxation.

In fact, any improvement which would serve the people of a city as a whole rather than the occupiers of a small area would be chargeable to general taxation.

Special Assessments.-The principle involved in paying for projected improvements by special assessments is quite different from that underlying the payments from general taxation. A definition of special assessment quoted some years ago from the Quarterly Journal of Economics by Flavel Shurtleff and Frederick Law Olmsted is worth repeating: 
"A special assessment is a compulsory contribution paid once for all to defray the cost of a special improvement to property undertaken in the public interest and repaid to the government in proportion to the special benefits accruing to the property named."

In all cases where special assessments are charged against specific property it is presumed that there is a direct economic benefit to the property, at least as large as the amount of the assessment. In almost every city in the United States street improvements are charged in whole or in part against the abutting property. Frequently the city pays one-half and the owners of the land on each side of the street pay onefourth.

In the taking of land for the opening of new streets or the widening of old ones there are several principles involved. Unless land is voluntarily dedicated for street purposes, as is frequently the case, it may be taken by "eminent domain." Under such procedure the value of the land actually taken would be ascertained and the price paid the owners. The owners, however, might claim offsetting damages in certain instances. In laying out open country the streets are ordinarily so clearly a benefit that the question of damages does not enter into the settlement.

When land is taken for the widening of streets the practice varies somewhat but perhaps the clearest statement is based on the custom in Kansas City, where juries must determine four values in order to arrive at the net result. First, the actual value of the land or right of way must be appraised. Second, the amount of damage, if any, to land and improvements not taken, must be ascertained. Third, the value of the improvement to the city at large, with a determination of the assessment to be levied from general taxation must be estimated. Finally, the special assessment against each plot of land, whether abutting directly upon the widened street or profiting from it, based on the ascertainable benefit to the land, should be figured. It will thus be seen that the owners 
of land would have credits for amounts determined under the first and second findings. If the special benefit exceeded the first two items the owners would pay the city an assessment. If the first two items exceeded the special benefit the city would pay the owners the net damage.

In practice the cost of opening a local street which gives access to land otherwise "dead" because inaccessible, particularly in down-town areas, is often met by special assessments on the abutting property and sometimes on a limited benefited area. Where streets are opened or widened to provide connections for the main arterial street system, it is assumed that the city as a whole will benefit, but if the abutting property or benefited area receives also a distinct increase in value, the charge against the general taxation may be lowered by the amount of special benefits determined. It is a question of fact to be ascertained whether or not the abutting property or benefited area will increase in value enough in the fairly immediate future to justify a special assessment for part of the cost.

The width of the street is sometimes taken as a rough gauge; that is, the cost of new streets under sixty feet in width, and purely local in character, might be assessed against the abutting property, whereas, possibly, one-third of the cost of opening through streets over sixty feet in width might be met from general taxation. On the other hand, the cost of a wide parkway in a residence neighborhood could very fairly be assessed against the property benefited for some distance on either side of the parkway.

In the opening of new subdivisions it is customary for the promoters to dedicate the streets to the city in return for the extension of public utilities, on the principle that the building lots thus opened for occupation will increase in value far in excess of the cost of the land given to the city for streets.

The application of the principle of determining and distributing the costs of street openings and improvements is dependent upon the accuracy of the estimates of the fairly immediate net results of the improvements. As the method 
of appraising property becomes more scientific and consequently the values become more correctly predictable, cities will be enabled to profit by reimbursement for all improvements to the extent to which these improvements increase the value of abutting or benefited property and will only be obliged to meet from general taxation such costs as cannot be equitably assessed against specific benefited areas.

Excess Condemnation.-A variation of the method by which cities may be reimbursed for expenditures for improvement is the practice of excess condemnation, by which the city condemns at its existing market value land in excess of that required for actual improvements, such as streets, parks, parkways and, possibly, sites for certain public buildings. The excess land may then be sold at its increased value. The increment which has been brought about by the improvement thus accrues to the city and not to the individual owner.

There is little question that a city should be authorized to purchase remnants and odd shapes of land which are too small to be useful after the taking of land actually needed for public improvements. In the United States, this is frequently permitted when excess condemnation for the purpose of protecting public improvements or for securing financial advantage to the city might not be permitted by the State law. In States where excess condemnation is held to be constitutional, it may well be used in connection with special assessments against benefited areas to aid in reimbursing cities for improvements which involve large expenditures of money and which benefit the city as a whole as well as the near-by property.

Arbitrary Assessment Districts.-Attention should also be directed to the theory of the Kansas City and Los Angeles park acquisitions. In these cases, the park system as a whole might well have been charged to the entire community; but, because of the difficulty of securing by popular vote adequate bond issues, and, in the case of Kansas City, because of the further complication of a bonded indebtedness limit which precluded extensive obligations, the total area was authorized to be sub- 
divided arbitrarily into districts which could reasonably be supposed to benefit directly by the part of the comprehensive park system assessed to each park district. In such cases the sum of the benefited areas equals the whole and the extensive park system may be built up without the necessity for persuading the residents in the north side of town that they should pay part of the costs for the parks in the south side of town in addition to part of the costs for the parks in their own neighborhood. The success of the practice is dependent upon the excellence of the comprehensive park plan. It can be worked out more equitably for parkways and neighborhood parks than for large outlying country parks, but the scheme has been found practicable when general bond issues for the purchase of park areas could not have been authorized.

Pyramiding Projects to be Avoided.-Needless to say the pyramiding of projects which would increase taxes beyond a reasonable figure, either by direct appropriation or by too heavy a bonded indebtedness, ought to be avoided. It would be equally bad management to attempt to run several improvements which would involve assessments against the same benefited area at the same time.

Significance of the City Plan.-The real significance of the city plan is that projects can wait their turn without serious disadvantage. Each improvement will fit into the plan when it is carried out. The plan makes it possible to proceed serially with the assurance that each part will fit into the whole. The expense may be districted over many years. But in cities where park acquisitions or school building programs have not kept pace with the increasing population it is not to be expected that the treasury can escape heavy strains. The false economy of long periods must be paid for in the end.

Economic Considerations in Changing the Map in Crowded Cities.-There are economic considerations involved in changing the map in crowded cities other than those of the direct cost of the projects. City planners are becoming quite generally agreed that wholesale and indiscriminate street 
widening is not a remedy for congestion and that most problems which seem to require such a remedy may be met in other ways, especially when a comprehensive plan is being designed to take care of all the outstanding needs of a community. Certainly the indiscriminate widening of streets in order to relieve traffic congestion in cities which permit progressive intensive use of the bordering land by erection of high buildings simply produces a vicious circle in which problems of congestion occur in cycles. Except for main thoroughfares the actual width of the street is not so important as the relation between the width of the street and the permitted use of the abutting property. A street which is congested to the point of slowing up traffic, or perhaps blocking it altogether at certain times of day, might better be extended than widened. When the occupation of business property furnishes more street traffic than the width of the roadway will carry the answer is not necessarily the widening of the street but the promotion of a greater spread of occupation, or decentralization. Of course the problem is sometimes met by building subways and using two or three levels; but this is only possible when considerable sums of money can be invested, and with the unrestricted occupation of land, the cycles of congestion may overtake even these heroic remedies.

Excess condemnation has been cited as a method of securing reimbursement to the city for expenditures on certain public improvements. When an area is poorly planned for the uses to which it should be put and particularly in areas which are ready for re-development because of the obsolescence or dilapidation of the buildings, there is often a decided economic gain to the city at large in the use of excess condemnation in order that the city may secure control of an entire area in order to replat it.

Easements and Setbacks.-We have been talking about the "pounds of cure" involved in remaking the map in crowded cities. In the United States there has been some utilization of "ounces of prevention." Many streets in America have 


\section{LAND PLANNING IN THE UNITED STATES}

been dedicated which were from 100 to 160 feet in width. But when the town was young it was not necessary to devote any great part of this width to traffic. When such streets were used for residence purposes there might be, perhaps, forty feet in the roadway, ten feet for sidewalks, and the remaining width thrown into the "yards" on either side of the street and cared for by the property owners. One or more rows of trees have frequently been planted in these easements. But when the time arrives that the street is taken over for business the city may resume its direct control and maintenance of the strips which the property owners have been maintaining as front yards.

In many cities there is a law requiring a setback of houses built. That is, an owner is not permitted to place his home on the front edge of his property but is required to set it back ten, twenty or forty feet. Setbacks are frequently required in residence neighborhoods with the purpose of making the district highly desirable for single-family homes set in wellplanted grounds. But as a preventive measure in city planning, setbacks on residence streets which may later be converted to business uses are highly commendable. The city is able to widen the roadway of such a street at a minimum of cost. Frequently the cost of acquiring the land in front of the building line is more than offset by the benefit to the property abutting on the widened thoroughfare; but whether this is the case or not, the cost of widening such a street and the physical difficulties of changing its arrangement are much less than in cases where buildings of many private owners must be remodeled or torn down.

Other Adjustments.-When cities have been allowed to grow up without the reservation of adequate open spaces it is often necessary to purchase built-up areas at great expense. We know now that parks and playgrounds should be reserved in advance of settlement, though, unfortunately, many cities are allowed to grow through the uncontrolled extension of building without regard to the provisions for balanced com- 
munities. The costs involved in securing recreation areas when buildings as well as land must be acquired are exceedingly heavy.

In general the cost of remaking the map involves paying for past mistakes. Whether the costs of making changes are assessed against a limited number of property owners or against the entire tax list, they must be paid. Intelligent city planning does not necessarily lower the first costs of public improvements, although it may do so, but it should prevent the next generation from paying for the avoidable errors of the people of to-day.

\section{SUGGESTED READING}

Flavel Shurtleff and Frederick Law Olmsted, Carrying Out the City Plan, the practical application of American law in the execution of city plans, New York Survey Associates, Inc., IgI4.

Flavel Shurtleff, chapter on "City Financing and City Planning," in

City Planning, edited by John Nolen. Second edition, I922.

Frederic A. Delano, Harland Bartholomew, George B. Ford, Lawson

Purdy and Hardean James, City Planning Procedure, American

Civic Association Bulletin, January, 1926.

Nelson P. Lewis, The Planning of the Modern City, Second edition, I92 I. Chapter on "Financing a City Plan."

Robert Eugene Cushman, Excess Condemnation, National Municipal League Series, I9I7.

\section{NOTES}

Page 305: Dr. John Nolen gives a graphic account of how Kansas City bought and paid for parks:

"Kansas City's park achievement under the principle of special assessment is so remarkable that some account of it mav prove of interest. In the early nineties certain men in Kansas City became impressed with the growth of the municipality and with the fact that the city had failed to make an adequate provision of park spaces for the people. An examination of the public property revealed the fact that the city owned in park lands less than onetenth of an acre, this being a triangular remnant which some real estate dealer had donated to the municipality.

"As a result of this investigation and awakening, Mayor Holmes appointed in March, 1892, a Park Board which at once went to work to study local conditions. In 1893 they published an extensive 


\section{Io LAND PLANNING IN THE UNITED S'TATES}

report setting forth the proposed improvements, and showing how they would be likely to affect the city's welfare. They found that the city was not only lacking in park lands, but also in power to borrow money, as the limit of indebtedness had been reached. Paradoxical as it may seem, to this discouraging state of the municipal credit is really due the possibility of Kansas City's splendid system of parks and boulevards, which has grown from nothing to 2500 acres of parks and fifty miles of carefully improved boulevards and parkways virtually without increasing the public debt, although thirteen million dollars have been expended in the work.

"The explanation is to be found in the scheme, which was devised and carried out as the logical method of paying for all park improvements. Around all proposed parks or boulevards, benefited districts were established. For the sake of convenience the city was divided into five park districts. The broad general principle applying that those receiving the benefit should pay the cost, opposition to any particular improvement was not aroused in localities remote from the improvement. ...

"One feature of the Kansas City boulevard work deserves special mention. Like nearly all western cities, most of the streets were platted with widths of from 50 to 60 feet. The landscape architect emphatically gave it as his opinion that no boulevard should be of less width than 100 feet with the added provision that, where car lines followed the boulevard, an extra width should be provided. The tendency of the Park Commission since that time has been to increase the minimum width to r 10 feet. To pay for the property taken, a jury decided upon the district to be benefited, which in general included land for a block and a half on either side of the intended boulevard. Then the cost of improvement of the boulevard itself was charged against the abutting real estate, land values only. In all cases the broad general principle was applied that the property benefited should pay for the improvement.

"The testimony is unanimous that the abutting property in all cases receives great increase in value from these park improvements. As an illustration, on the Benton Boulevard the average gain in value per front foot above all costs of construction was $\$ 26.50$; on the Linwood Boulevard, $\$ 32$; Gladstone, \$4I; and Harrison, $\$ 52.30$. This shows an average gain in value of 325 per cent over the value of abutting real estate prior to the establishment of the boulevards. Thus has Kansas City secured one of the most splendid and adequate park systems in the United States, and, instead of being a burden in taxation, it has been without cost to the public treasury and has actually put money into the pockets of those who have paid the bills, simply because the resulting benefits in all cases exceeded the cost."

Page 306. Under the "Mattoon Act," approved by the Governor of California May 23, 1925, the acquisition, planning and improvement of highways, parks, pleasure grounds, commons and all public ways may be undertaken through assessment districts and the issuance of bonds. 


\section{SELECTED BIBLIOGRAPHY ON CITY PLANNING}

Theodora Kimball, Manual of Information on City Planning and Zoning, including references on regional, rural and national planning, Cambridge, I923.

Nerson P. Lewis, The Planning of the Modern City, Second edition. John Wiley \& Sons, I922.

Frank B. Williams, The Law of City Planning and Zoning, The Macmillan Co., 1922.

Chardes Mulford Robinson, City Planning, with special reference to the planning of streets and lots, G. P. Putnam's Sons, I9I6.

John Nolen, Editor, City Planning, A series of papers presenting the essential elements of a city plan, D. Appleton \& Co., 2nd printing, 1922. National Municipal League Series. 


\section{PRINCIPAL PERIODICALS IN WHICH CITY PLANNING ARTICLES MAY BE FOUND}

American City (monthly), Civic Press, 443 Fourth Avenue, New York

City. Harold S. Butenheim, Editor.

American Institute of Architects, Journal of the (monthly). Press of the American Institute of Architects. 250 West 57th Street, New York City.

American Society of Civil Engineers Proceedings (monthly except June and July). 33 West 39th Street, New York City.

City Planning (quarterly). American City Planning Institute and National Conference on City Planning, City Planning Publishing Co., 9 Park Street, Boston, Mass. Henry V. Hubbard, Editor.

Housing Betterment (quarterly). National Housing Association, I05

West 22nd Street, New York City. Lawrence Veiller, Editor.

Landscape Architecture (quarterly). Landscape Architecture Publishing

Co., Combridge, 38, Mass. Henry V. Hubbard, Editor.

National Conference on City Planning, Proceedings, issued annually since I909. Flavel Shurtleff, Secretary, I30 East 22nd Street, New York City.

National Municipal Review (monthly). National Municipal League, 26I Broadway, New York City. Harold W. Doods, Editor.

National Real Estate Journal (bi-weekly). Porter-Bede-Lantry Corporation, 139 North Clark Street, Chicago, Ill. George E. Henry, Editor.

Parks \& Recreation (bi-monthly). American Institute of Park Executives and American Park Society, Rockford, Ill. Will O. Doolittle, Editor.

The Journal of Land and Public Utility Economics (quarterly). Institute for Research in Land Economics and Public Utilities. Richard T. Ely, Editor-in-Chief. 


\title{
SECTION III
}

\section{NATIONAL AND STATE PLANNING}

\author{
CHAPTER XVIII
}

\section{PIECEMEAL LAND PLANNING}

When we think of comprehensive planning with the Nation as the unit, it does not seem surprising that the planning of the country as a whole has developed in fragmentary fashion. It is easy to forget that the present boundaries of the United States are of fairly recent origin and that during the lifetime of many now living the sparsely populated territories of the continental United States have been erected into co-ordinate commonwealths. There are no more "territories" on the main land. The area is divided into the forty-eight States and the District of Columbia.

Area of the Republic. $-\Lambda$ fter the Revolution the newly created Federal Government had jurisdiction over the thirteen original States and an indeterminate area lying generally east of the Mississippi River, south of the Great Lakes and north of the present northern boundary of Florida.

From 1781 to 1802 the various States ceded to the United States 406,2 I9 square miles. In $1803,827,987$ square miles were added to the national domain by the Louisiana purchase. In 1819,72, IOI square miles were added in the Florida purchase which was ratified by the Treaty with Spain. From 1845 to $185^{\circ}$ the annexation of Texas and the Texas purchase increased the national domain by 383,483 square miles. In 1846 the acquisition of the Oregon territory added 264,096 square miles. In 1848, 529, I69 square miles were acquired from Mexico, and in 1853 the Gadsden purchase rounded out 


\section{I4 LAND PLANNING IN THE UNITED STATES}

the boundaries with 22,762 square miles. By these various means in a little less than seventy-five years the United States acquired $84 \%$ of the present land surface of the country.

The present boundaries of the continental United States, therefore, have existed less than seventy-five years, which, ordinarily, in the life of a nation is but a short period of time. But, measured by progress in dedicating land to various uses and appropriating it for fairly permanent purposes; gauged by the highways and streets laid out, by the railway routes and rights of way in active use, the period has been of enormous importance. The discoveries which have led to the revolution in methods of transport have been responsible for the building of railways and highways on a scale never before witnessed in the world's history. We cannot doubt that the next seventy-five years will see enormous expenditures of energy and money in further extensions of routes of land and water communication.

There has been little conscious, consecutive planning for the layout and appropriate use of the land, either in its relation to the immediate community or in its relation to the Nation as a whole. So far as the thought of successive Congresses can be traced, our national legislators evidently pictured the entire area of land in the United States in private ownership, with the possible exception of sites for actual Federal and State activities and easements for rights of way to provide for communication. Farms were to form the mosaic on the rural map. Cities, towns and hamlets were to form trading centers and the government would go out of the land-owning business.

Disposition of the Public Domain.-Up to 1853 the United States repeatedly added to its public domain. The States ceded to the Government during the first quarter of a century $267,730,560$ acres. Through the successive additions to the territory of the United States there came into the direct ownership of the Federal Government 1,309,591,580 acres, more than four-fifths of the main-land area now under the 
jurisdiction of the United States. Not all of this existed at one time as public domain. But the Government has had the disposition of $\mathrm{I}, 399,000,000$ acres of land.

Professor Hibbard has told the story of the distribution of the public domain. The long succession of homestead acts by which settlers were induced to put land under cultivation has hardly shown a consecutive, consistent policy. But the prevalent belief that "the wilderness was and ought to remain free to the man who should subdue it," and the fact that the country was literally weighed down with land which it could not expect to protect unless it placed a population upon it, explain, if they do not justify, the ardent efforts of Congress to dispose of the public domain and place it in private ownership at any cost.

But, as Professor Hibbard sagely remarks, "giving land away does not permanently revolutionize a land system." Lands forced into cultivation at a time or in a location which will not permit a family to exist on the products will ultimately be put to other uses or revert to the Government. Abandoned homestead lands, before title is perfected, fall back into Federal ownership. Many acres of land purchased from the railways or other sources have been forfeited to the States for nonpayment of taxes. In other words, lands will not stay in private ownership unless they can be put to some use which will bring returns sufficient to pay the taxes. There are exceptions, but in the long run, the tendency is quite definite.

Permanent Public Lands.-Moreover, we shall see that certain land uses are now recognized in the United States as appropriate for government ownership, both Federal and State, so that, not only are we setting aside great areas of the public domain for national forests and national parks, but in recent years we are purchasing further extensive tracts of forest and water-shed land through National and State Governments. In the Southern Appalachian Mountains public-spirited citizens are now raising funds to purchase park areas to present to 


\section{I 6 LAND PLANNING IN THE UNITED STATES}

the Federal Government as a part of the Great National Park System.

It may be, as the years go on, that other uses will prove to be adapted to public ownership. For the present public forests and parks in National and State ownership will add to the permanent public lands.

Distribution of Public Domain.-In round numbers the public domain has passed into ownership as follows:

Acres

Homesteads, Timber Culture, Desert Land Reclamation ............................ 256,000,000

Sales, cash and credit................... 220,000,000

Forest Reserves, National Parks and Monuments..... I I $70,000,000$

Railways, Wagon Roads and Canals............. $137,000,000$

Education ............................ 99., $99,000,000$

Military bounty land..................... $68,000,000$

Swamp land grants....................... 64,000,000

Mineral and Power Reservations.............. 48,000,000

Indian Reservations....................... 35,000,000

Timber and Stone..................... 25,000,000

Miscellaneous grants to States, claims pending, etc... 79,000,000

Remaining Public Domain.................. I66,000,000

In the disposition of these vast areas into private ownership our forefathers were faced with two dominant problems in the first years of the Republic - the need for population and the need for revenue. Their ideas concerning the functions of the National Government were very modest but they were harassed to find ways and means for securing a working minimum income necessary to keep alive. There was a pretty general opinion that the sale of public lands over a period of years should form an important source of revenue. But when the infant Republic finally did survive those precarious years of experiment and discovered other and more easily collectible funds, the Congress yielded to the pressure for free land, or practically free land, to be wrested from the wilderness by pioneers who would provide the population to insure the stability of the Nation. 
Not only has the Federal Government disposed of easilycultivable farms, it has provided for the draining of swamp land and the reclamation or watering of dry lands. The careless, if not dishonest, classification of swamp lands placed in private ownership many acres of land which should never have been included in that category. Under the swamp-land grants, Professor Hibbard states that an area greater than the States of New York, New Hampshire, Vermont, Massachusetts, Connecticut, Rhode Island and New Jersey passed from the ownership of the general government. Finding that the homestead laws did not fit the conditions on the desert lands, the Congress tried a number of experiments culminating in the series of reclamation acts which have brought into cultivation land otherwise ill-adapted to crops. It has been discovered that while it may be physically possible to store water and distribute it over dry lands, the cost may not be recoverable from the sale of the crops produced on the land because of their quantity, quality or distance from market.

The Federal Government from the theory of making a charge for farmsteads passing into private ownership, therefore, advanced to the theory of free land, then to the policy of expending money for draining and reclamation in order to place settlers upon it. In each of these periods there has been some land speculation-mostly disastrous to the speculators as well as to the misfit settlers.

Balanced Land Uses.-But we are not so much concerned here with the methods by which the land once in the public domain passed into private ownership as in the condition which now exists when the great bulk of the public domain which it is profitable to cultivate (and some which it is not) is now in private ownership. We are concerned with the uses to which that land is being put-whether it is being used in a way that is alike profitable to its owners and to the nation. We can recognize great, outstanding blunders by more or less casual observation. After too much wheat has been produced for readily available markets we can see that mistakes have 


\section{I 8 LAND PLANNING IN THE UNITED STATES}

been made. After an entire section of the country has depended on a single crop which falls victim to a pest we can see that diversified crops offer better assurance of an annual income to the cultivators of the soil.

Our problem is rather to forestall mistakes before they occur, to discover the possible uses of land based on physical characteristics and modified by markets which in turn must be considered from the point of view of prices and distances. This leads, inevitably, to nation-wide planning, since all products must be considered as a part of the nation's total supply in relation to the nation's total demand, for the moment disregarding possible exports. The range of prices caused by overproduction of any one crop may mean just the difference between prosperity and disaster.

While we must take private land as we find it, with the prevailing rectangular surveys, often in uneconomic units, frequently laid out for settlement in badly-balanced farms, some of these conditions can be corrected if there are profitable uses to which the land may be put so that capital will be available to bring it into economic units of some sort.

We have now placed in private ownership practically all the cultivable lands which can be used for general farming or even for the growing of crops. Unless money is spent for drainage or reclamation there are no more considerable crop lands for distribution on any plan. The public domain consists largely of mountainous areas and arid plains. There is ample testimony to show that even in the semi-arid regions, when put to the only purpose for which the land is fit, that is grazing, 640 acres is insufficient to support a family. In other words, for income producing purposes it would require much more than 640 acres of dry grazing land to equal 160 acres of rich farming land in the Mississippi Valley. In spite of the tragedies induced by the errors of the Government in establishing homestead units which would not support a family, the land is still in existence, and there are no insuperable obstacles to 
prevent bringing it into suitable uses in economic units which will support a family.

Public Domain and Communication.-Congress established the rigid rectangular surveys which determined the regular net-work of public roads which exists in the United States to-day wherever the topography will possibly permit. These roads affected the size and shape of the agricultural units as well as the direction of travel. The subsidizing and laying out of canals and railways stimulated the settlement of remote regions and the routes of travel often bore a national significance even though the authorizations were made piecemeal. The Union Pacific Railway bound the east to the west by a route which is scientifically sound to-day. But the routes of the tangled cross-hatches of connecting railways of the last half of the nineteenth century were not always chosen to serve the needs of regions to the best advantage, to say nothing of serving the Nation as a whole. On the whole piece-meal planning has characterized the routing of railways in this country, and a hard-and-fast arbitrary gridiron system of highways has been superimposed pretty generally over the map. Custommade national planning is apt to be quite as disastrous as piece-meal local planning.

Mineral and Oil Lands.-Without reviewing the history of how the mineral and oil deposits have passed into private ownership in the past we must recognize that we are only beginning to develop a public policy in regard to the ownership and utilization of these valuable resources. To mention only one of the basic products of the nation, it must be apparent that there is no national policy with respect to the economic mining and marketing of coal.

Power Resources.-A few years ago Congress passed a Water Power Act designed to open up the water power of the country for development by municipalities, companies and individuals. Whether we have placed sufficient safeguards around the development and control of the water power of the United 
States remains to be seen. Certainly the act as originally passed included areas which could hardly have been included had the public interest been consulted. Through the prompt action of the Secretary of the Interior, Judge John Barton Payne, approved by President Wilson and supported by the civic organizations, the act was amended to exclude the National Parks from the jurisdiction of the Water Power Act.

Principles of City Planning and Zoning Applicable to Nation.-If city planning may be said to be the public control, through planning in advance, of the physical treatment of public and private land and its appurtenances in the interests of the community as a whole, land planning may be said to be the public control, through planning in advance, of the physical treatment of public and private land and its resources in the interests of the country, State or region as a whole. Just as intelligent city planning has not operated as an objectionable limitation on the rights of land owners to the use of their property, but has, on the contrary, contributed to protect values and legitimate uses, so the broader land planning would contribute to a more profitable utilization of land resources for owners and a better distribution of products to consumers.

In city planning we have the master or key plan which covers the city-wide framework and to which more intensive planning must conform but which does not prescribe in any other respect local, detailed planning. In land planning for the Nation we should have the arterial highway, railway and water travel systems with which local routes should articulate, frequently through the medium of State and county systems. We should have a better utilization of land to produce and market agricultural products. We should have forest reserves, public parks, water power, mineral resources, whether in the hands of municipalities, States, Federal Government or private citizens, part of a great master plan but designed by local communities or owners in minute detail. 
We must never forget that our artificial political boundaries cannot be seen on the landscape, that cities fade almost imperceptibly into the suburbs and finally into the open country, that routes of transport may traverse many jurisdictions, that however much we subdivide our land areas and delegate specific authority to local communities or States we have but a single land and water surface reflected on a single area map.

Because of the difference in the uses to which rural land is put and the specific requirements for developing certain land and water resources, land planning as a whole will require a very different combination of technical advisers; but the principles of city planning may be applied to the planning of land uses. In order to practice land planning for the Nation or any given area, we need first the inventory or survey. Just as in city planning no inventory or survey is static. Nothing short of a continuing inventory will truly represent the changing conditions. But it is possible to make a survey of the fixed features and to forecast the trend of population and probable land uses.

With such an inventory in hand, land planners may then proceed to apply the principles of zoning to rural areas, not necessarily through governmental control, but through a system of land classification which would guide private owners to an intelligent and profitable utilization of land within its physical and economic limitations, and which would set up a basis for holding appropriate areas in public ownership.

The technique for accomplishing these highly desirable ends has not been developed very broadly, but certain beginnings have been made both in specific fields and in the general subject. A study of what has already been accomplished should offer a guide for future achievement. At any rate, there is quite as good reason for displacing piece-meal planning in favor of comprehensive planning for any given. area in the general field of land planning as there is in the field of city planning. 


\section{SUGGESTED READING}

Richard T. Ely and Edward Morehouse, Elements of Land Economics, The Macmillan Co., I924. Chapter II on "The Characteristics of Land," Chapter III on "The Classification of Land," and Chapter V on "The Present and Future Utilization of Land."

Benjamin Horace Hibbard, A History of the Public Land Policies, The Macmillan Co., 1924.

L. C. Gray, "The Field of Land Utilization," in The Journal of Land and Public Utility Economics, April, 1925.

P. S. Lovejoy, "Theory and Practice in Land Classification," in The Journal of Land and Public Utility Economics, April, I925.

Warren H. Manning, "A National Plan Study Brief," Special Supplement to Landscape Architecture, July, I923. 


\section{CHAPTER XIX}

\section{PUTTING LAND TO ITS PROPER USE}

The first requisite for putting land to its proper use is an adequate system of land planning, involving continuous inventories, pertinent classifications, and intelligent application of the assembled information to land management, whether in public or private ownership.

From the abandoned farms of New England which, after years of use, could not compete economically with the fertile fields of the Mississippi Valley to the abandoned ranches of Montana which never were suited for general farming crops we might record thousands of tragedies where innocent homesteaders or purchasers were induced to undertake to put land to a use for which it was not suited in physical characteristics or which, during a given period, could not be cultivated with profit. These victims of circumstance were foredoomed to failure. They had not the technical knowledge to save themselves. But they could have been saved from disaster by being placed in possession of ascertainable information which would have shown them that no amount of industry could wring success from ventures in agriculture lacking sound elements necessary for economic farming.

Agriculture, of course, is only one of many uses to which land may be put. Considered from the economic point of view, Dr. Gray has defined land utilization as "that branch of land economics which comprises the study of the land resources of a nation or other geographical unit from the standpoint of their economic significance with a view to determining for what and how they may be most effectively employed." In its broader aspects, economics includes values adhering to 
land because of satisfaction, comfort, health, æsthetic appeal, and neighborhood, growing out of its occupation for living quarters in town and country as well as its ability to supply necessities and luxuries to the population at large and earn an income for its owners.

Dr. Ely has listed the characteristics of land as legal, physical, economic and social. He quotes from Kent's Commentaries the definition of real property which brings within the meaning of land "not only the ground or soil, but everything which is attached to the earth, whether by the course of nature as trees, herbage and water, or by the hand of man, as houses and other buildings; and which has an indefinite extent, upward as well as downward, so as to include everything terrestrial, under or over it." Needless to remark this definition drawn from Lord Coke was written many years before men found any means to use the air, entirely unattached to the land or any appurtenance on it.

Marshall's economic definition of land to include "the material and forces which nature gives freely for man's aid in land and water, in air, light and heat," is even more comprehensive and far-reaching in its application. At any rate, we have come to recognize in practical business that when we purchase real estate we usually purchase the economic, if not the legal, unit of land and the improvements upon it. This is not always true. In Baltimore and other parts of the United States, land is frequently owned by those who issue 99-year leases which are negotiable and which result in a salable unit consisting of the improvements and a ground rental of a fixed amount over a period running for several generations. But whatever the legal characteristics, we may think of land with its improvements as providing a single income-producing unit.

When we come to consider the physical characteristics of land we are apt to think, first, of soil, exposure, climate, geological composition or topography. But the economists direct our attention to the immobility of land and the train of results dependent upon this characteristic. We have all specu- 
lated, probably, on what would happen if the Grand Canyon were only adjacent to New York City, if the Yellowstone could be brought to Illinois, if the Iowa farm could be transferred to the hinterland of Boston. But alas, we must use land, in general, in the place where it is. The steam shovel has been employed to reform the contour of our cities, but it cannot be invoked to move the soil of Kansas to cover the arid regions of Arizona. Except within narrow limits through the conservation of moisture in forest plantations, we cannot change the climate, much less transport it from one section of the country to another. The topography of land is its own. The geological deposits must be mined into material which is in size and value worth carrying from one place to another. The fact that land must be used where it is found, influenced as it is by its. own physical composition and its location in regard to climate and topography, apparent as it seems to be, has been ignored by many of the exploiters of the frontier. It is worth remembering that the outstanding physical characteristic of land is its immobility.

With the best husbandry which science can suggest we still have fertile lands and poor lands. Certain types of "kindly" soil may be improved with more success than others, but no amount of treatment brings the rocky, shallow soil of New England to resemble the deep, black, loamy soils of Illinois. It seems entirely unlikely that either the soil or the climate of New England could ever be transformed to produce bountiful corn crops. The variation in fertility represents definite, though not unmodified, gradation in value.

One of the most potent economic characteristics of land comes through the differences in advantageous situations. Of what use is it to produce strawberries in quantity if there is not direct and rapid transportation to centers of population where strawberries are consumed? Of what use is it to produce bumper crops of wheat if the haul to the railway cars and the transport by rail cost so much that they wipe out all the profits? Huge premiums are paid every day by capitalists 


\section{LAND PLANNING IN THE UNITED STATES}

to command advantageous situations in the commercial districts of our cities. As applied to residence property, advantageous situations include more than convenience to transport and availability of utilities. The purchaser of a home seeks amenities, described by Dr. Ely to mean "beautiful scenery, a pleasant neighborhood, congenial neighbors, and all other inducements which add to the pleasure and comforts of living."

Another physical characteristic of land which Dr. Ely lists is its durability, that is, with proper management land will continue to produce crops for endless years without exhibiting marked changes. A coal mine after the coal is taken out is hardly a natural resource. An Ohio farm may be cropped for a hundred years and still remain a valuable Ohio farm capable of producing crops for another hundred years.

Dr. Ely points out that the law of diminishing returns by which a definite limit to the application of capital and labor to land is set by the "diminishing returns" which occur at a given point, and the relative scarcity of land for the uses which are most in demand, together with the slowness with which uses of land can be adapted to changes in prices, set the terms of the problem of economic uses. These economic characteristics have been overlooked much more frequently than the more obvious physical characteristics, but they are none the less important. No intelligent assignment of land to its most fitting use can be made without consideration of these three important economic characteristics.

But of all the characteristics of land most generally ignored we may site the social aspects. Dr. Ely recalls the great "political and social power" which attach to land ownership, but he points out the principle which is invoked in community control incident to effective planning. "The more intensive the use of the land," he declares, "the more highly developed must be the social control." There is every reason to believe that with the doubling and trebling of the population of the United States we shall be obliged to develop social control beyond the limits reached through planning and zoning up to this time. 
Those who hark back to the good old days of complete individual liberty to use land without social control of any sort, of course, are describing a situation which never did exist and which, even in the modified form which prevailed on the frontier, is not likely to occur again on the mainland of the United States.

The Land Inventory.-Having in mind the characteristics of land, a land inventory, to be an effective guide for land uses, should list in some convenient form the land resources of a given area. No merchant would conduct a considerable business without making detailed inventories at regular intervals. The United States Government as the agent of the people is just waking up to the fact that Uncle Sam needs a complete inventory of his land resources in public and private ownership. Fortunately Uncle Sam has forty-eight districts and something over three thousand local subdivisions, not counting the cities and towns, in which he can count on co-operation in discovering his immediate and potential assets.

In the section on City Planning reference was made to the various map-making agencies of the Federal Government. There are the topographical surveys, showing contours, but not listing types of cover with the exception of a general indication of "woodland." The civil-base maps seldom show topography. The soil maps prepared by the Federal Government indicate certain highly technical terms to show soil content, but one would never dream that a certain brown spot designated in the "legend" as "sandy loam," really fell in the middle of an apple orchard. As a matter of fact the "farm advisers" from the experiment stations are kept busy explaining to prospective settlers in many regions that the soil maps are not conclusive evidence of the use to which certain farm lands ought to be put.

Mr. Lovejoy refers to the "farm-management surveys" conducted by the Department of Agriculture which record and analyze "the details of family and labor income, compute interest rates upon invested capital," and occasionally take note of the size of the farm unit. The United States Biological 
Survey conducts surveys to chart "the ranges of rodents and wildfowl," but has not issued information, states Mr. Lovejoy, covering the "normal carrying capacity of typical ranges in terms of deer, beaver, or quail."

These surveys, all valuable to some one for some purpose, are conducted separately and issued in separate maps, all of which, taken together, do not furnish complete information, capable of being placed on a map, which a prospective settler or purchaser in any section ought to have at his disposal before risking his labor and his money in a farming venture.

We have seen that the public domain was transferred to private ownership without any adequate inventory of quality and classification for use. We have referred to the failure of many reclamation projects because some of the important elements affecting the farmers were ignored. We shall see how the indiscriminate withdrawal of forests from the public domain included many areas better suited to other uses because no information was available which gave anything like an adequate description of the lands. For a score of years the Forest Service has been inventorying and classifying its lands in a way which has developed intelligent policies. Land better suited to agriculture has been eliminated. Grazing and recreation have found a secondary place within the National Forests.

But it was not until agriculture had been overtaken by "hard times," not until the great engineering feats of huge reclamation projects had been overshadowed by the failure of the farmers to carry the financial load, not until the accumulated penalties for the unjustified "land booms" began to be doled out to the victims of the inexorable "reaction," that there developed scientific movements to prevent recurrence of these widespread maladjustments.

President Harding's "Agricultural Conference" brought together many of the ablest leaders in the country-specialists in scientific agriculture in all its phases. It also called in the economists. Dr. Ely urged the classification of land "with a 
view of determining what areas should be devoted to crops, to grazing, to forests, since we have distinct policies for each one of these kinds of land."

In the meantime it was beginning to dawn on the public that something was wrong with agriculture. For all the scientific information dispensed by the Federal Government in co-operation with the State authorities, the farmers were not making both ends meet. Something more was needed to put farming on a stable, business basis. Marketing was an important part of farming business, but there were other economic elements. In the quiet reorganization which has been going on within the Department of Agriculture a "Bureau of Agricultural Economics" has been established, with a division paying special attention to the problems of land economics.

Paralleling the trend of theory being worked out in the Department of Agriculture and perhaps preceding it in point of time, a distinct and pathfinding movement was developing at the University of Wisconsin, led by Dr. Richard T. Ely who has pioneered in the field of economic theory for nearly half a century.

The Institute for Research in Land Economics.-In October of 1920 there was organized "The Institute for Research in Land Economics and Public Utilities," with a distinguished Board of Trustees, now consisting of Dr. Albert Shaw, President, Editor of the Review of Reviews; Judge M. B. Rosenberry, Vice-President-Treasurer, of the Supreme Court of Wisconsin; Dr. Richard T. Ely, Director; Dr. John H. Finley of the New York Times; Dr. Henry C. Taylor, eminent agricultural economist; Colonel Henry S. Graves, Director of the School of Forestry, Yale University; Mr. W. S. Kies of W. S. Kies Company, New York City; General Nathan William MacChesney, Chicago; and Honorable Frank O. Lowden, Sinnissippi Farm, Oregon, Illinois.

In the autumn of 1925 the Institute moved from the University of Wisconsin to become affiliated with the School of Commerce of the Northwestern University, with headquarters 


\section{LAND PLANNING IN THE UNITED STATES}

to be established on a lake-front site near Lincoln Park, Chicago. Already the founders have made a profound impression upon the economic thought of the people at large in regard to land problems. Through the research of graduate students the Institute should build up a great body of detailed information concerning land economics and public utilities on which new principles and laws can be based. There are few fields in which we are so lacking in accurate information covering the years of modern urban and rural development. Economic information and interpretation has lagged behind the scientific discoveries in the physical sciences.

The Institute is issuing a series of books on Land Economics and its staff is engaged in giving courses at the University of Wisconsin and Northwestern University in various phases of land economics and public utilities. The Institute has conducted courses in real estate and land economics under the auspices of real estate boards and the Y. M. C. A. Schools of Commerce. A series of texts to be used in the standard course in real estate outlined by the Joint Commission representing the National Association of Real Estate Boards, the United Y. M. C. A. Schools and the Institute for Research in Land Economics and Public Utilities, is being issued. For the first time, a definite, constructive effort is being made to bridge the gap between the academic theorists and the business men who actually deal in land.

Thus it is becoming possible in the universities and in the special schools of commerce for students and those already engaged in business to study the principles governing real estate. The whole problem of city planning rests upon the development and treatment of real estate in cities. The wider problem of land planning in the nation as a whole, in the States, in the rural districts, in the towns and in the cities and their environs, is not only tied up with real estate but with the policies of those who deal in real estate. It is, therefore, a most hopeful indication that at the very outset of these researches in land economics the organized real estate men 
and women of the country should collaborate in outlining a real estate course based on careful studies of facts and tendencies.

It does not seem improbable that in the general field of land planning there should develop some such co-ordinating methods as evolved in the practice of city planning. In both the services of a wide range of specialists are needed. In both leadership and co-ordination are needed. We have seen in the making of comprehensive city plans leadership sometimes falls to the architects, sometimes to the landscape architects, and increasingly on engineers who have training and experience in city planning. We have seen that the neglect of the economists has often curtailed the usefulness of those who could make great plans, but who could not provide the means for carrying them out. In the field of land planning we shall doubtless see leadership emerge from the various technical groups; but whether in the guise of co-ordinator or collaborator, the land economist will play an important rôle.

The Michigan Land Economic Survey.-Perhaps the most important demonstration of the new method being developed is the Michigan Land Economic Survey. Leaders in Michigan woke up to the fact that this great and prosperous State had depleted its once valuable timber resources, had developed a disturbingly extensive absentee land ownership, and seemed headed for a repetition of the depressing decline of farming which took place in New England a generation earlier. The idle land in Michigan was not much of an asset from any point of view.

In I919 the Michigan Academy of Science turned its attention to the problem which was confronting the State, and which, it is now developing, is troubling other States. Dr. C. I. Sauer, now head of the Department of Geography at the University of California, organized the recommendations of the Academy in the Annual Report issued by the Academy in 1920. He thought that an inventory of the great areas of idle lands should be made which should include adequate information 


\section{LAND PLANNING IN THE UNITED STATES}

as to "(I) physical conditions, such as soil, climate, cover; (2) economic data, such as history and status of existing utilizations, trend of population, tax and fiscal affairs." At the

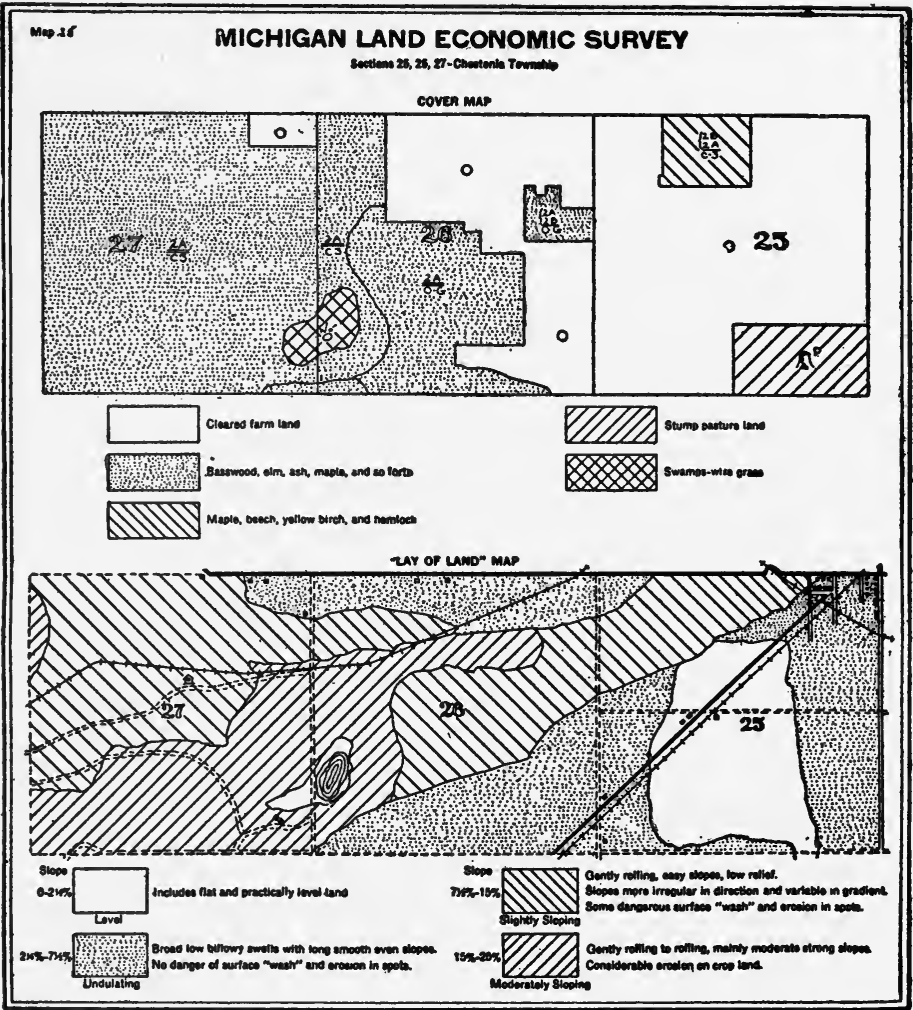

From an article by P. S. Lovejoy in "The Journal of Land and Public Utility

Economics," Volume I, Number 2, published for the Institute for Research in Land Economics and Public Utilities, by A. W. Shaw Company.

outset it was determined that the survey should use the scientific personnel of the State and seek such Federal co-operation as it would be possible to secure. Here was co-ordination and leadership being furnished to make it possible for the various scientific specialists to function effectively. 
Fortunately for Michigan, an old and forgotten statute which authorized a "Soil and Economic Survey" was resuscitated, and the services of the State University, the Agricultural College and the State Departments of Agriculture and Conserva-

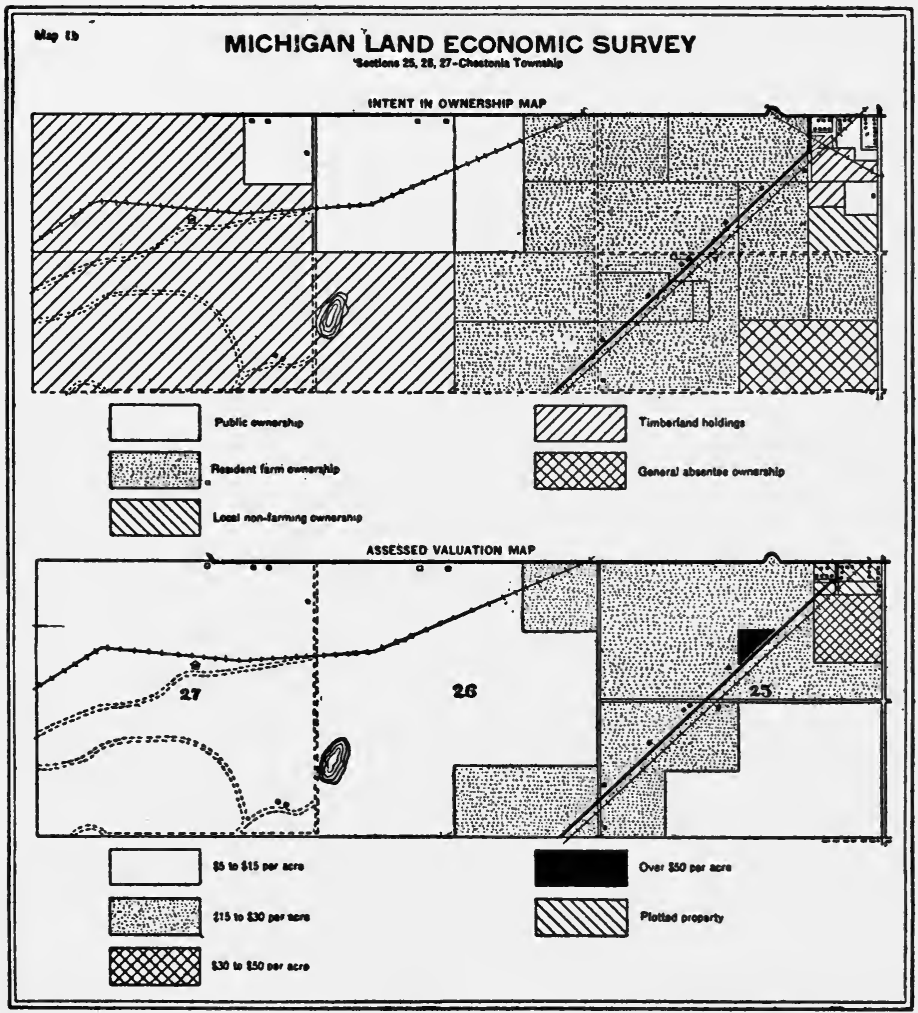

From an article by P. S. Lovejoy in "The Journal of Land and Public Utility Economics." Volume I, Number 2, published for the Institute for Research in Land Economics and Public Utilities, by A. W. Shaw Company.

tion were secured. Mr. Lovejoy has told us that "when the first field season had demonstrated the complete feasibility of the general plan and the urgent need for such inventory work, the State Department of Conservation adopted the new 'LandEconomic Survey,' provided funds, and continues to operate 


\section{LAND PLANNING IN THE UNITED STATES}

the survey. No doubt these maps will become quite as worn from use by the various State and local officials as those dogeared sheets prepared in Cincinnati for the comprehensive plan of the city.

The Michigan Land-Economic Survey which has covered more than a million and a half acres of typical cut-over land, has developed a new technique. It has established, according to Mr. Lovejoy, the inventory as a prerequisite to classification and planning. This is tremendously important when it is remembered that there are, perhaps, $250,000,000$ acres of cutover lands in the timbered States which must be put to some use if they are not to constitute a "drag" on our standard of living in the United States. Such land must come into use, if it is rescued from its idle and unproductive state, for reforestation, for farming or for recreation which may frequently be incidental to a purely economic use. As Mr. Lovejoy tersely remarks, "Industrial uses of land, water-powers, mineral developments, and the like, important and feasible as they often are, will at most utilize but a small fraction of the total acreage involved. It is, therefore, a case of farms, forests, and recreation-or nothing; with 'nothing' signifying wholesale bankruptcies," as unquestionably indicated by the 700,000 acres of tax-delinquent land which has already reverted to the State of Michigan, where the State is rapidly becoming an impoverished landlord.

The Inventory.-The personnel and technique of the survey are of special importance in view of the precedents which are being set. The permanent staff included a forester, a soil surveyor, a land economist and two general utility aides. Specialists in other fields were called in as needed. The work went forward in three surveys: (I) civil-base data-topography, cover and utilizations, (2) soils, (3) land and related economics. A prospective purchaser who went into one of the surveyed counties in Michigan, not only could discover reliable information concerning the soil and past use of any land in the area, but could find mapped, classified, and analyzed 
the topography, the cover, the present ownership and the assessed valuation not only for specific areas in which he might be interested but for possible competing areas in the region. In Roscommon County, for example, the classification of ownership in 1924 showed that more than half of the area of the county was in public ownership or general absentee ownership. Only about one-eighth of the land in the county was in actual use. Such a prospective purchaser could be saved from investing capital in land at a rate on which he could never expect reasonable returns from any one of the three principal uses to which the land could be put. Yet, the surveyors have managed to adopt inventory classes which reflect actual facts rather than attempts to grade the land in a way which would arouse antagonism of the private owners and land selling organizations. One of the outstanding achievements of the survey in the territory so far covered is that "the lines between super-marginal, marginal, and sub-marginal lands seem to be indicated with even greater precision than was to be hoped for and without involving any form of arbitrary or debatable assertion."

Land Classification.-Classification of any sort is a most elusive subject. Library cataloguers have long since discovered that one sort of physical classification precludes an exactly different, but sometimes equally important, classification. There is found to be a definite limitation for cross-references, whether for libraries, government departments or land characteristics. Therefore, the Michigan Survey in the classifications which it has adopted, following closely as they do, the selective fact inventory, is building up precedents for the inventory and classification of similar areas in other States. This classification might not be found equally applicable to all rural lands. Indeed, even in Michigan, a composite classification, involving cover, lay of land, intent in ownership, assessed valuation cannot be evolved from the inventory maps.

It is evident, however, that all these data might be gathered, and doubt still exist as to the best or highest use to 


\section{LAND PLANNING IN THE UNITED STATES}

which a given area might be put. Cleared land does make good farms under favorable conditions. It can also be reforested. Sometimes it furnishes grazing facilities. But it is more than probable that we shall be surprised to find that a careful

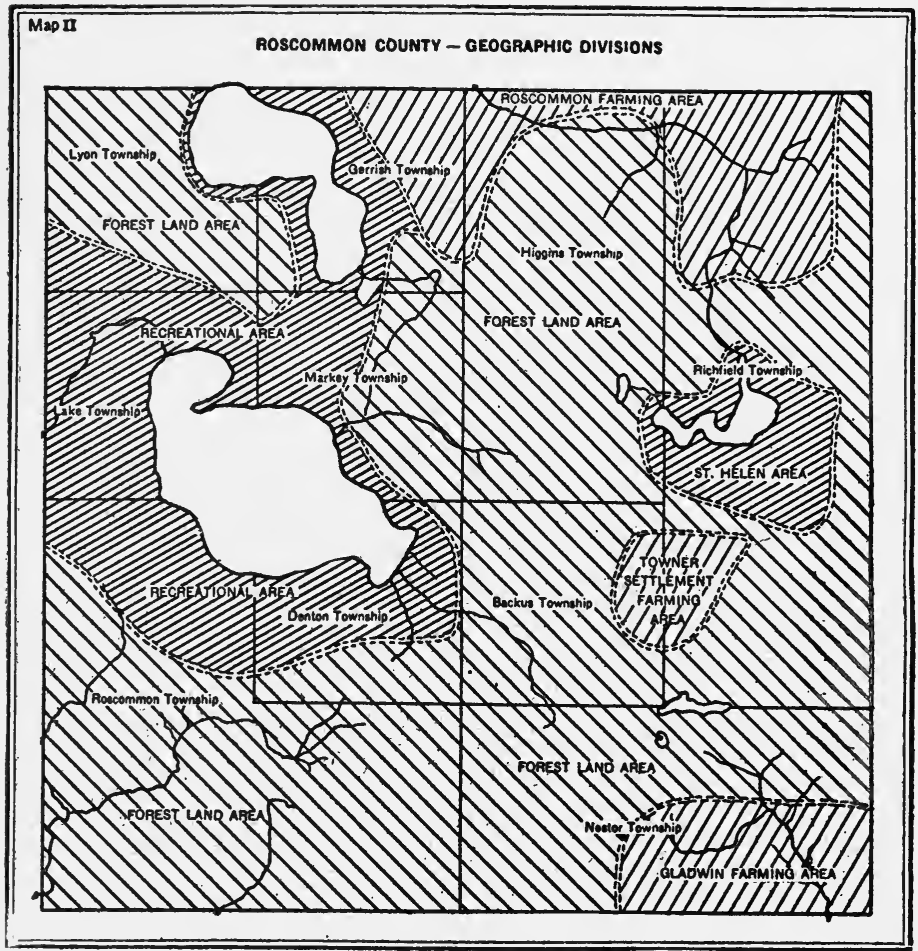

From an article by $P$. S. Lovejoy in "The Journal of Land and Public Utility Economics," Volume I, Number 2, published for the Institute for Research in Land Economics and Public Utilities, by A. W. Shaw Company.

analysis of the probable returns to be expected from farming a given cut-over area, will, for a given period of time, determine without much doubt, whether that particular piece of land ought to be reforested, put under cultivation, or developed into grazing ranges for stock.

Dr. Ely has suggested an outline of uses to which land may be put. Some of the uses are conflicting, as applied to a 
single piece of land. Some of them can be co-ordinated on the same land without harm to either; though, in most cases, it will be found that there is a point where even carefully coordinated uses become conflicting, and at this point it ought to be clearly defined as to which uses are primary and which secondary. Forest land may often be used for grazing without harm to the forest, if the grazing is controlled in the interests of scientific forestry. But if the reverse is true, a 50- or 75-year crop may be injured out of all proportion to the gains to be secured by unregulated grazing.

Dr. Ely's Suggested Classification of Natural Resources.

A. Sub-surface appropriation-oil, gas, minerals, stones, salt, etc.

B. Surface appropriation:
I. Site purposes
a. Urban
$\left\{\begin{array}{l}\text { Manufacturing } \\ \text { Mercantile } \\ \text { Residence } \\ \text { Recreation }\end{array}\right.$
$b$. Building sites, non-urban

2. Land for agricultural purposes
a. Arid land $\left\{\begin{array}{l}\text { I. Irrigable } \\ \text { 2. Non-irrigable }\end{array}\right.$
Timber
$\left\{\begin{array}{l}\text { Grazing } \\ \text { Dry Farming } \\ \text { Desert }\end{array}\right.$
b. Humid land $\left\{\begin{array}{l}\text { I. Natural appropriation } \\ \text { 2. Cultivated }\end{array}\right.$
Forest \& Pasture
Swamps for rice, hay, cranberries
Farm
Garden
Forest

3. Land for transportation and communication

4. Recreation land $\left\{\begin{array}{l}\text { Natural parks } \\ \text { Forest and stream } \\ \text { Highways }\end{array}\right.$

C. Water and land connected with it

I. Shore lands

2. Land under water

3. Riparian land

4. Irrigation water

5. Navigation water

D. Super-surface appropriation for the aeroplane and radio 


\section{LAND PLANNING IN THE UNITED STATES}

Land Planning.-It will be seen that any adequate land planning for uses to which land can be economically put must involve inventories of characteristics, past and present uses,

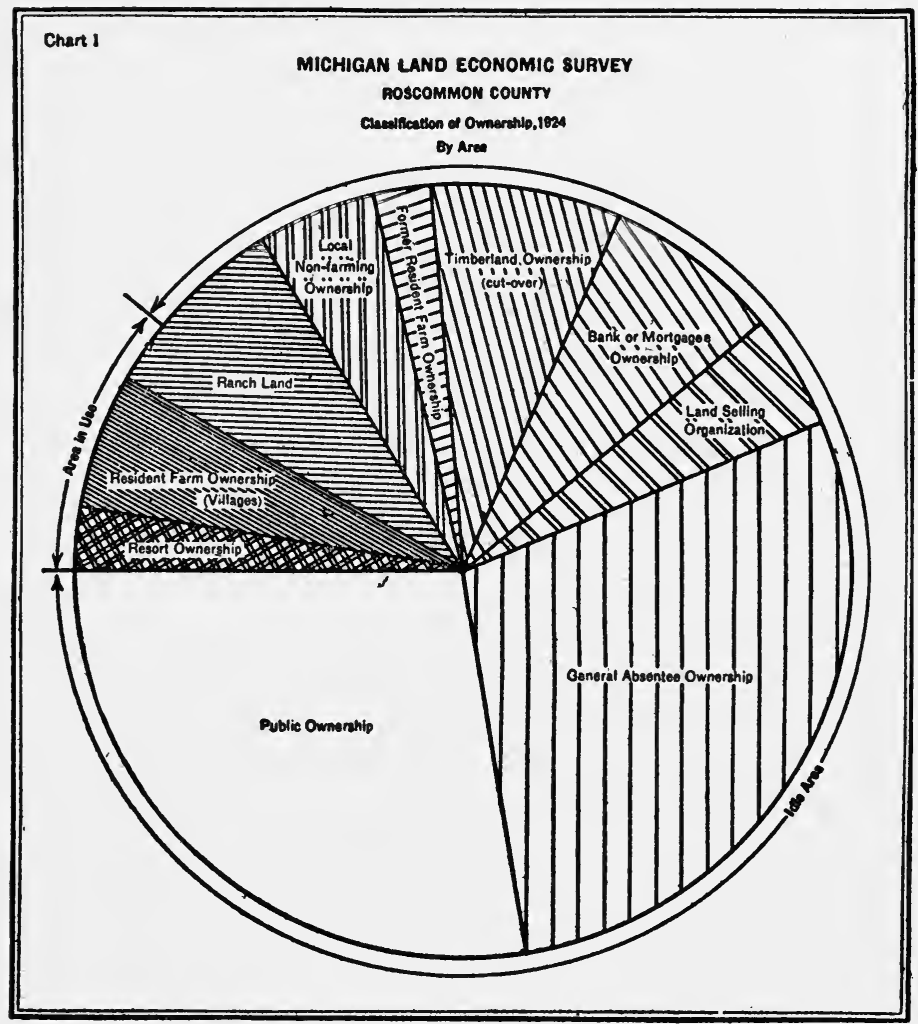

From an article by $P$. S. Lovejoy in "The Journal of Land and Public Utility Economics," Volume I, Number 2, published for the Institute for Research in Land Economics and Public Utilities, by $A$. W. Shaw Company.

with estimates of value based generally on assessments for taxation purposes. The classification into categories suitable for the possible spread of uses will then need to be evolved. Even after these two steps are taken there will ordinarily need to be considerable flexibility in assigning future uses to given 
areas of land because of a certain amount of adaptability inherent in certain areas and because of changing conditions of population, industry and markets which make certain uses unprofitable in one period and highly profitable in another.

The Michigan Survey has proved, if we did not already know it, that the hard-and-fast permanent classification between publicly and privately owned land is not possible. It has shown the tendency of lands to revert to public ownership when they are not being utilized for some purpose which will bring in fairty immediate and regular returns. It may be that private capital, earning 2 or 3 per cent on investments, to be collected like deferred dividends on life insurance policies, at the end of forty or fifty years, will flow into forest-growing ventures. Much private capital has been expended in metropolitan regions with little better chances for income though possibly the determining motive for investing money in a skyscraping tower would be found in personal pride and advertisement rather than in the conscious acceptance of the low income.

At any rate, we cannot fail to recognize the marked tendency for cut-over lands to revert to public ownership. In fact, there is a definite trend which pushes unproductive land of any sort into government ownership. We have witnessed the tendency for income-producing land, with fairly regular annual returns, to gravitate to private ownership. A public opinion might develop which would hold such land in public ownership; but it has not operated except in the conservation policies under which we have to-day our great National Parks and Forests, together with certain other valuable resources.

In the examination of special classes of land and water resources we shall see that, while great areas of the country will easily fall into well-recognized classes, there will be considerable spaces for which there will be contests over conflicting and mutually-exclusive uses. These contests cannot be equitably settled by local decisions. Only by the long-range balanced judgment covering the comparative needs for different 
land uses can the borderland cases be settled in the interests of the people as a whole.

\section{SUGGESTED READING}

Publications in the Standard Course in Real Estate outlined by the Joint Commission, representing The National Association of Real Estate Boards, The United Y. M. C. A. Schools, and The Institute for Research in Land Economics and Public Utilities. Published by The Macmillan Co.

E. M. Fisher, Principles of Real Estate Practice, 1924.

Richard T. Ely and Edward W. Morehouse, Elements of Land Economics, 1924 .

Frederick M. Babcock, The Appraisal of Real Estate, 1924.

WARD C. GIFFoRd, Real Estate Advertising, 1925.

Herbert U. Nelson, The Administration of Real Estate Boards, 1925. ClaRK-Chase, Elements of the Modern Building and Loan Associations, 1925 .

In the LAND Economics SerIes the following have appeared:

Benjamin H. Hibbard, $A$ History of the Public Land Policies, 1924.

Frank B. Williams, The Law of City Planning and Zoning, 1922.

The Journal of Land and Public Utility Economics, which appears quarterly, is presenting the recent theory and practice in the subject.

The articles by L. C. Gray and P. S. Lovejoy, cited at the end of the last chapter also apply to this.

The Department of Agriculture, Yearbook, 1923.

Michigan Academy of Science, Twenty-second Report, 1920.

\section{NOTES}

Page 329. In the announcement of the Institute for Research in Land Economics and Public Utilities the purpose and scope of the organization was described:

"The scope of land economics is as large as that of property rights in land and natural resources.... In the complex civilization in which we live to-day, nearly every phase of life to which we turn presents problems of property rights in land or in natural resources. ... .

"It is a sad fact that heretofore but slight attention has been paid to the principles which govern this pervasive relationship between men that rises out of their relation to the land. But until recently mere mention was made of them in economic treatises and but few texts have ever appeared in which they were set forth. Vital though the subject is, it is still untouched by the hand of the scientific investigator. Legislatures have to deal with these problems in a way that affects us all, but they are forced to proceed empirically 
in the absence of any careful analysis of the principles involved. In some countries the whole subject has become the prey of party politics and cannot easily be approached from a detached point of view. In some parts of America a similar situation is arising. . . .

"The very occupation of the land and the utilization of its natural resources involve costs and problems which have never been analyzed. The real estate of our cities carries more than threefourths of the costs of city government. A great share of the burden of the city budget of taxation rests upon the owner of the land. In some cities the growth of the population and of urban value is checked by unwise taxation policies, and scarcely a city exists but needs scientific methods of assessment which will assure fairness to all without danger to the city's treasury.

"Land settlement and colonization plans have been carried on without proper consideration of underlying economic factors. Great developments have failed in the moment of success because of a disregard of fundamental economic principles. Each year an enormous waste in money and a tragic loss of human effort-which means human life-could be avoided by the application of economic science to the problems of land settlement and colonization.

"Investors in city property are frequently lured to financial destruction by the promise of large increments in their investments. Instances are multiplied of the almost fabulous increases that have come to city real estate values in the course of twenty, thirty, or even fifty years. But the element of costs is left out of all such considerations. The mind of the buyer is dazed with an array of glittering prospects of reaping where he has not sown, and he is allowed to forget that taxes must be paid every twelve months, that special assessments, frequently equal to the increase in the value of the property, must be met, and that money invested in real estate, if put instead into a savings bank at four percent and compounded semi-annually, would double itself every eighteen years. The neglect of these costs in land utilization leads to many hopeless investments. ... .

"It was inevitable that the study of problems connected with land and land utilization should lead to the parallel study of public utilities. The value of land, for example, is in a very vital sense dependent upon the public utility service with which it is supplied. The city addition cries for street car service, and more and more it waits upon the installation of other public utilities before it can be successfully marketed. The exact relationship which exists here, however, has not been adequately analyzed.

"Our policies of control of public utilities are almost as various as the number of public utilities to be controlled, but little effort has been made to study the results of these policies. When State and municipal authorities look for a critical analysis and an unprejudiced appraisal of the various policies, they look in vain."

Page 334. In his article on "The Theory and Practice in Land Classification," P. S. Lovejoy describes the inventories in some detail:

"The civil-base map shows the land net; streams and lakes; roads, buildings, and other improvements, and, where important, their quality and condition, especially whether used or abandoned. 


\section{LAND PLANNING IN THE UNITED STATES}

"Topography is shown in five classes, from level and in need of drainage to very steep and broken. Contours would be preferable but proved too costly for the present.

"'Cover,' as shown, includes forest, swamp, grass, and other forms of 'wild' growth, and also all lands under any defined forms of agriculture or other utilization, such as tilled, orchard, pasture. Abandonments are shown as such. . . . The cover symbols number nearly 50 and permit of indefinite combination to express almost any possible, and all important cover complexes. Units down to to acres are shown.

"Forest growth, and whether the growth is original or secondary, is recorded under a system worked out in co-operation with the United States Forest Experiment Station. The maps indicate the species in the mixture, their relative importance, stand density ('thick, medium, thin,' and so on) and the prevailing diameter ranges (which of course correlate to ages).

"When the maps are planimetered, the total acreage of each typical or important forest growth and condition can be tabulated for species, density of stocking, and size or age. ... When the results are available, for any given area or land type, it will be known what volume and quality of forest products are to be anticipated in the normal course of events. . . .

"The classification of forest and other wild growth was worked out in co-operation with professional biologists as well as with foresters. As this phase of study has been handled it is readily translatable into terms of wild-life habitat, which, as in the case of forest products, can be (and is being) given technical analysis in order to determine the carrying capacities, degrees of stocking, and limiting factors in the biological complex which must be understood and balanced before deer, beaver, trout, or partridge populations may reach, or be held at, anything like their maximums. . . .

"To link cover and wild-life with recreational resources, the character of stream and lake shores and bottoms is recorded by the survey, together with beaches, favorable building sites for summer resorts, and similar features.

"In the larger water areas, approximate depths, bottom conditions, and the character and location of aquatic vegetation are mapped. ... With aquatic habitats mapped, the specialists in fish-culture will know the location, mileage, and acreage of the several characteristic combinations, can plan the order of technical investigations needed to refine and apply the base data, and can adapt their planting and other field operations with a certainty of success that has been long wanting and previously impossible. ...

"Following the field men who map base and cover, come the soil surveyors. ... .

"Economic and glacial geologists, meanwhile, have been refining their data in their fields, and the hydro-engineer has been running his levels and investigating storage and power sites. Peat and marl deposits are sounded and sampled. Prehistoric earthworks and the like are accurately located and reported to the authorities in archæology. ... .

"Having prepared a plat showing separately each parcel of rural 


\section{PUTTING LAND TO ITS PROPER USE}

real estate and its. assessed value, a county map is made to chart assessed values of all lands by classes. . . .

"By interviewing township supervisors (in Michigan also rural assessors) the land economist also learns and records the character of each land holder, such as bona fide farmer, new settler, squatter, "resorter," absentee speculator, lumber firm, mortgagee. When platted against assessed values and the soil and cover maps, the relations between land types and ownership become evident. When platted to show percentages of the local tax burden carried by the several types of land and owners, the essential facts as to the incidence of taxation and its significance are easily read.

"The history and status of colonization and similar land-selling projects is especially inquired into."

Mr. Lovejoy states that field work is done on a scale of 4 inches to the mile and requires a total summer crew of about 20. The total cost of the field work, not counting the contributed work, comes to about $2 \mathrm{r} / 2$ cents per acre. 


\section{THE FOREST LANDS AND CUT-OVER AREAS}

The people of this country have cut, consumed and wasted more timber, probably, during the last hundred and fifty years, than was ever destroyed in a similar area and time in the history of the world. Of the three million square miles of the continental United States it is estimated that two-fifths were covered with forest. The Eastern division contained over a million square miles in a broad, continuous strip from Maine to Florida. The Western division was broken but spread over some 245,000 square miles.

The pioneers never thought of the forests as a crop. It seemed to them that there was an inexhaustible supply of trees. Their problem was to "clear the land" to make way for annual crops which would provide food and clothing. "Hostility to the forest became ingrained in the American spirit," says Herbert A. Smith. "To free the soil from its mastery was to serve the cause of progress, to create wealth, to help build an empire."

As an industry the lumber business developed slowly. Timber was consumed by the population near the forest. Except along the coast near the harbors it was not easily transported. But the development of the steam railway changed all this. In 1840 the population of the United States was I $7,000,000$ and its per capita consumption of lumber is estimated at 85 board feet. In 1850 , with a population of $23,000,000$ the per capita consumption was 230 board feet. Expansion continued until 1906 when $46,000,000,000$ board feet of lumber was cut and the capital invested in the lumber business exceeded a billion dollars. In 1907 the per capita consumption 
was 500 board feet. In 1920 it had dropped to 316 board feet.

The movement to protect the forests and to promote tree planting had small beginnings shortly after the Civil War. In r872, "Arbor Day" was inaugurated. The settlers who had moved from the forest-clad hills of the Atlantic Coast were beginning to plant trees in the open prairie.

In 1875 there was organized in Chicago the American Forestry Association. The purpose of the organization was to promote "a permanent and sufficient supply of forests." It was believed that forest cover exerted an important influence upon water and soil conditions and that utilization of soils suitable chiefly for forest planting was necessary to national prosperity. And particularly it was desired to fight that great enemy of forests-fire. The Association was the principal agency in the creating of public sentiment which made possible the establishment of the Federal service, which, under a succession of names, but with increasing power and responsibility, has contributed the constructive policies by which we profit to-day. In the nineties many of our national forests in the West, then known as forest reserves, were saved to the people of the United States by the persistent efforts of the American Forestry Association. The passage of the Weeks law providing for the acquisition of lands protecting the headwaters of navigable streams was secured largely through the leadership of the American Forestry Association. The Clarke-McNary law which was enacted by Congress in 1924 received broad support through the activities of the association.

The American Forestry Association has made a definite and valuable contribution to the subject of land economics through its insistence that "certain lands are chiefly valuable for timber growing." It has continuously maintained that "the allotment of such lands to their best economic use is fundamental in land planting." The endeavor to classify public lands with this end in view is to-day bearing fruit in the demand for a more thorough and far-reaching classification than has yet been at- 
tempted. Moreover it is doubtful if the keen public interest in conservation policies developed in the Roosevelt administration could have reached the high mark if it had not been for the years of organized endeavor under the American Forestry Association.

Federal Service.-Running parallel to the sentiment of the lay organization the Federal service has grown from small beginnings. Under an act of Congress in 1876 a special agent was appointed in the Department of Agriculture to collect information concerning forestry. In I88I the Division of Forestry was established in the Department of Agriculture. By Act of Congress in 189 I the President of the United States was given power to establish forest reservations, and President Harrison established the Yellowstone Park Timber Reserve. The Act of June 4, 1897, authorized the administration of the forest reserves which were then under the Department of the Interior. The Act of February I, 1905, transferred the forest reserves and the authority to administer them from the Secretary of the Interior to the Secretary of Agriculture. In July of 1905 the Bureau of Forestry became the Forest Service. In 1907 the name "forest reserves" was changed to "national forests," to correct an impression that they were withdrawn from use.

Up to IgII the national forests were secured by setting aside publicly-owned land as forest reserves or national forests. With the passage of the Weeks law in IgIr, Congress authorized the purchase outright of mountain lands from private owners in the Appalachian and White mountains of the East. More than two million acres have been acquired under the Weeks law.

In June of 1924 the Clarke-McNary Act passed Congress. This act extended the function of fire-fighting "to any timbered or forest-producing lands within the co-operating States," instead of confining the protection to forest lands on the watersheds of navigable streams. The act authorized increased appropriations for reforestation and made provision 



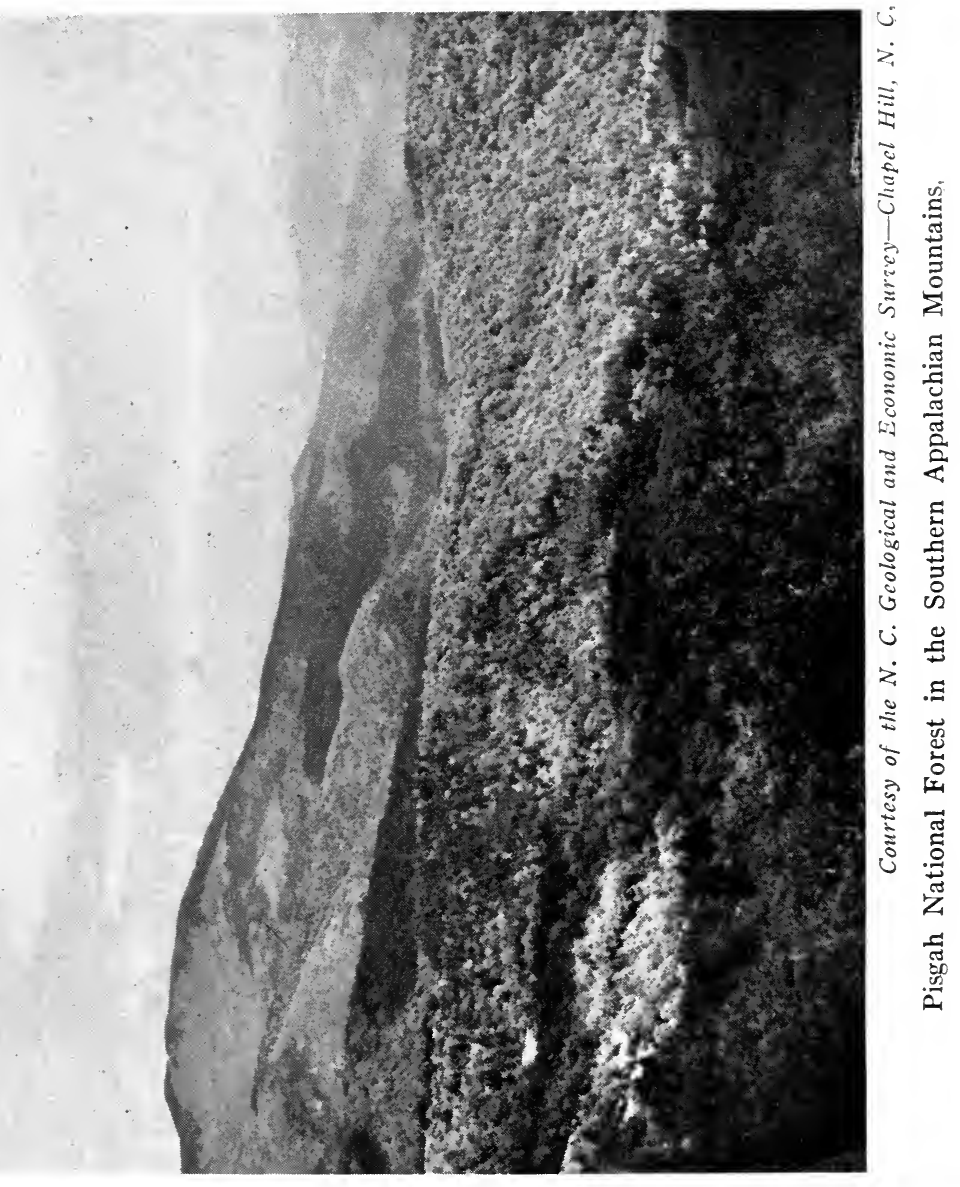


for furnishing farmers with forest tree seeds and plants for farm woodlots, windbreaks and shelter-belts. The act, if followed by adequate appropriations, should make it possible for the Forest Service to put into effect far-reaching national policies of forest replacement and forest protection. Other recent legislation gives to the Service more freedom in making land exchanges in order to bring into the national forests additional areas suitable for timber production.

One particularly important provision of the Clarke-McNary law should stimulate better classification of the public domain. Under this provision the remaining unappropriated and unreserved public lands of the United States may be examined for the purpose of finding land valuable for stream-flow protection or timber production. The results of these examinations may be presented to Congress by the President with a view to incorporating them in the National Forests. Under this act a large number of military areas have been transferred to the Forest Service for administration, subject only to recall in case of military necessity.

In the Report of the Forest Service for 1925 , Colonel Greeley, Forester, renders an account of his stewardship and presents a résumé of the accomplishments for the twenty years of the existence of the Forest Service under the administration of the Secretary of Agriculture. "The most significant change in our forest situation within recent years," declares Colonel Greeley, "is the degree to which timber growing has become a matter of general interest and understanding and a use of the soil actually applied by private agencies." In the State of Maine, it is said that over 9,000,000 acres of forest land are being handled under some form of forest management. Nearly a score of lumber companies in the South have begun to practice reforestation to provide a dependable future supply of timber. On the Pacific Coast, the largest private owner of virgin timber in the Northwest has employed a trained forester to advise concerning methods for perpetuating timber growing on its forest lands. In California the replant- 


\section{LAND PLANNING IN THE UNITED STATES}

ing of redwoods has been undertaken, and it is expected that by the winter of 1930 the annual planting area will equal that cut over annually. From the point of view of maintaining an adequate timber supply all this is encouraging, and is undoubtedly due to the combined influence of the Federal Service and various lay organizations led by the American Forestry Association.

The National Forests have come to stay. Not only has it been proved that forestry is a branch of agriculture which can be applied with profit as a business proposition, but it has been demonstrated that the Federal Government can administer a vast estate in the interests of the public as a whole. While the Forests in the direct ownership of the United States will never comprise all of the extensive forests in public ownership, yet they will form the great stabilizing nucleus and make sure that in periods of excessive economic demand the policies of conservation will not be sacrificed for immediate lucrative supply.

There are now in the National Forests $184,126,000$ acres of which $158,395,000$ are Government-owned. It is estimated that fully 97 per cent of the public lands of the United States best suited to the growing of trees and not dedicated to other purposes are already under the jurisdiction of the Forest Service. Under the Clarke-McNary Act a procedure has been set up to make it possible to bring into the National Forests all the public domain suitable for the purpose. Other additions to the great national forest system must come from purchase or gifts or possible reversions.

In the twenty years of management under the Department of Agriculture the timber cut has increased from 68,475,000 board feet to $1,038,000,000$ board feet and the receipts have advanced from $\$ 85,596$ in 1905 to $\$ 2,940,438$ in 1925 . This supply of timber has been furnished through the practice of scientific forestry without depleting the supply and without injuring protective watershed cover or certain scenic areas conscientiously preserved by the policies of the Forest Service. 
In addition to the landed forest estates of the Federal Government, many of the States of the Union have undertaken extensive State forests which are administered under policies similar to those of the National government. The States are also endeavoring to stimulate the reforestation of private lands and the scientific management of woodlots. New York maintains a nursery which had available $10,000,000$ trees for distribution to farmers and others during the year 1925. It is expected that the output from this source will reach $35,000,000$ or $40,000,000$ trees by 1927 .

It is estimated by the Forest Service that about one-third of the remaining forest land is in the form of farm woodlots,or more than $150,000,000$ acres, with a yield in 1920 of forest products to the value of $\$ 394,32$ I,828.

Through the National and State public forests, through the holdings of lumber companies administered under scientific principles for maintaining a permanent supply and through the proper management of woodlands owned by farmers, it may confidently be expected that the end of the next fifty years will find the United States on a firm basis of timber production.

Principles of Land Use.-Under the law the National Forests were created for two major purposes, the production of an adequate supply of timber and the protection of sources of water supply. The production of timber on the public forests includes not only the scientific cutting of existing forests but the reforestation of cut-over areas which is accomplished by replanting and by protection which in many parts the country permits a natural re-growth to spring up. Indeed the Service has actually produced in the semi-arid sand hills of Nebraska a thriving pine forest which can be seen for many miles across the sands. With the annual planting an extensive green forest cover will ultimately be established on land which in the known history of man has never borne trees. The effect of this forest on the surrounding land will be studied and 


\section{LAND PLANNING IN THE UNITED STATES}

possibly the surrounding area may develop increased value as well as the forest land itself.

The value of stream-flow protection can hardly be overestimated. Comparison of any moist farming land along perpetual streams with the arid or semi-arid areas subject to long dry seasons and fed by intermittent flow of the streams from the mountains will carry conviction to any doubter that the forest cover of watersheds, remote as it may seem, is a basic necessity for the maintenance of well-watered agricultural lands. Moreover, more than 1200 municipalities and towns secure their water from sources within the National Forests.

Classification of Lands by the Forest Service.-One of the most constructive contributions to the land policies of the United States has come through the systematic classification of land under its jurisdiction by the Forest Service. Through the inventory and classification of lands, the Service has been enabled to hold only those lands which, in the judgment of experts, are suitable mainly for forest production or water-shed cover. Lands suitable for agricultural purposes have been rigorously excluded through return to the public domain. Approximately 23,000 homestead units have been carved out of the land released by the Forest Service as suitable for farms and ranches. Moreover, through a system of exchange, the forest units have been greatly consolidated into convenient administrative units.

But it must be apparent to anyone who has observed the habits of forest growth that absolutely hard-and-fast lines cannot be drawn. The south slopes of wooded areas are generally covered with grass or barren rocks. These could not be excluded from the forest lands for obvious reasons. Moreover, the forest lands begin frequently with scattered trees on the foothills which shade gradually into closer stands on the mountain sides. These areas of mixed grass and trees are often indispensable to water-shed protection and even to the safe administration of the heavily-forested regions, particularly in the protection from ravages of fire. Then there are the 
high mountains and plateaus above the timber line where for a brief period in the summer forage for stock may often be found.

Grazing a Secondary Use in National Forests.-Thus we find within the National Forests much land which is suitable for the grazing of stock. In I924 more than $90,000,000$ acres within the National Forests were used at some time in the year for the grazing of stock, which in 1925 included about eight million head under some 30,000 separate permits. During the twenty years of forest administration of these grazing areas, through the regulation of stock grazing, the Forest Service has restored many acres of worn-out range to fair productiveness, thus adding to the livestock resources of the country and preventing erosion which ensues when stock are permitted to destroy all cover. While grazing within the National Forests is a most important use of land suitable for the purpose and definitely adds to the food, hide and wool resources of our people, there are areas on which grazing is distinctly a conflicting and not a co-ordinated use of forest land. All over-grazing, of course, is detrimental to the land both for future use and for adequate cover to prevent erosion. In newly-planted areas, or where it is desired that the young trees in standing forests be permitted to grow at an unhampered rate for the production of timber in an economic period, grazing is undoubtedly a menace to timber production. It is only through rigid regulation of grazing, in the interests, first, of forest growth and cover protection, and, secondly, for maintenance of forage, that grazing should be permitted within the National Forests. A given area of land cannot be administered for two conflicting purposes any more than a man can serve two absolutely-opposed masters.

Priority of Uses in the National Forests.-During the past twenty years, states Colonel Greeley, "one underlying principle has been consistently followed-to bring about a co-ordinated and balanced use in order to obtain from each area the greatest aggregate of public benefits and the most 
valuable forms of service. . . Protection of forests from fire and other destructive agencies holds first place, the production and use of timber second, and the production and use of forage third. Other activities, such as road and trail building, provision for recreation uses, where not essential for the protection or management of physical resources, are assigned a lower rating."

One of the important co-ordinated uses of the National Forests has been the development of game preserves of various sorts. Antelope, bear, deer, elk, moose and mountain goats and sheep still exist, in varying numbers, within the public forests. The Service co-operates with the Biological Survey in the proper preservation of wild life.

Since many of the National Forests are selected to protect water sources on the high areas, many proposed power developments fall within the forests; but, though there has been close co-operation between the Forest Service and the Federal Power Commission, there is urgent need for a comprehensive investigation of the water-power resources of the National Forests which is delayed only because of lack of funds.

Economic Considerations.-The principal reason that the conservation of forests has become in large part a public function is that the crop is a long-term crop. While many far-seeing lumber companies of large resources are being persuaded to provide a permanent timber supply for the future through the practice of scientific forestry, private capital cannot be expected to gravitate to investment in a crop which will not mature in the lifetime of the investor. In the volume on "Characteristics and Classification of Land," Dr. Ely has shown the costs of carrying timber land over a period of years, including the taxes which are commonly levied on private timber land. Some of the States are experimenting in tax laws which require owners to pay a small annual tax based on the value of the bare land and provide for a proper tax to be collected from sales of timber as they are made. Such an arrangement will probably stimulate the extension of woodlots 



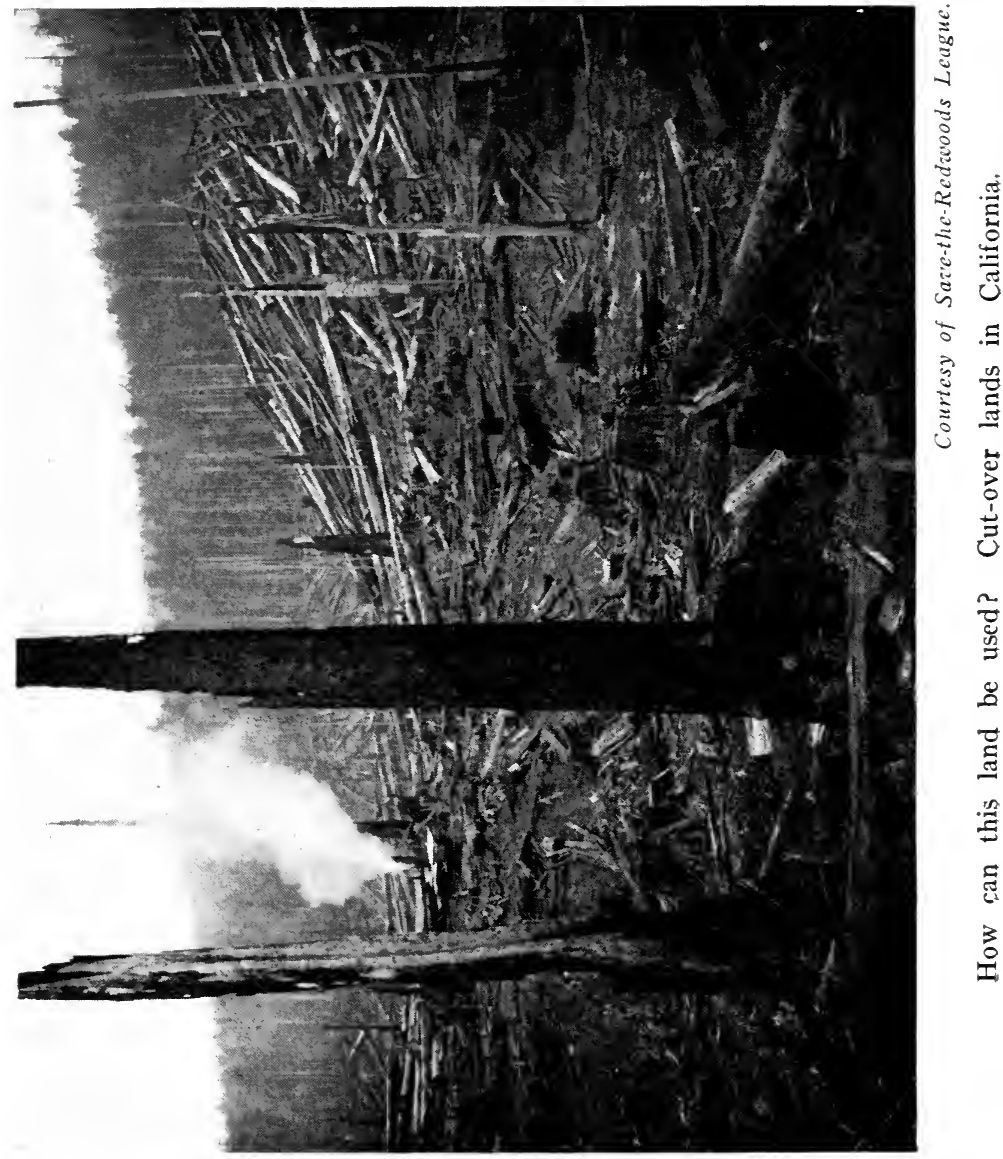


and possibly induce more lumber companies to replant cutover areas.

An aspect of the administration of the National Forests in those Western States where large areas are thus removed from the taxable quotas of the States has brought about a co-operative program under which the Forest Service develops roads and other utilities through the forests for the use of the general public in crossing forest lands. The other means of making compensation to the States for lack of taxes is the transmission to the State treasuries of part of the income received from the sale of timber and grazing fees from the forests.

But whatever these adjustments, the outstanding achievement of the past twenty years is the establishment of a definite policy of protection of existing forests which permits a proper use of the resources and the reforestation of areas classified as mainly useful for forests, whether in public or private ownership. Public ownership will probably increase in the next twenty years. The McNary-Woodruff Bill now pending in Congress would authorize the acquisition of nearly ten million acres over a period of ten years in the Great Lakes and Appalachian Mountain regions and in the South.

But the vast stretches of cut-over land cannot be brought back into production by so modest a program. The co-operation of the States and of private citizens must be brought into service if the dreary cut-over wastes are to be redeemed. The method and purpose of the Michigan Survey have been outlined. The Survey was undertaken primarily to find out the exact situation in regard to the cut-over and other unused lands of the State. When once the best use for such lands is ascertained it seems reasonable to believe that gradually the cut-over lands will be reforested or put to some use which can be established on a profitable basis. The State has in its control the adjustment of taxation on private lands and it has jurisdiction over State-owned lands. With the vast resources which are demanded by the consuming public in the way of wood products we may confidently expect that many of the 


\section{LAND PLANNING IN THE UNITED STATES}

cut-over lands will be reforested, and the land thus put to the use for which it is best suited. Only through careful inventories and scientific classification involved in wise land planning can we expect satisfactory physical or economic results.

\section{SUGGESTED READING}

Herbert A. Smith, Forests and Forestry in the United States, United States Department of Agriculture, supplement to Brazil Exhibit.

United States Department of Agriculture, The Importance of Forestry and the National Forests, Misc. Circular 15, March, I924.

United States Department of Agriculture, Report of the Forester, for the fiscal year ended June 30, I925.

Richard T. Ely, assisted by Mary L. Shine and George S. Wehrwein, Characteristics and Classification of Land, Institute for Research in Land Economics, I922. Chapter X on "Forest Land."

W. B. Greeley, "The Stockmen and the National Forests," in The Saturday Evening Post, November 14, 1925.

Henry S. Graves, "The New Public Lands Controversy," in American Forests and Forest Life, January, 1926.

P. L. ButrRick, "The Forest or the Shepherd?" in American Forests and Forest Life, February and March, I926.

United States Department of Agriculture, Henry S. Graves, Forester, Principles and Procedure Governing the Classification and Segregation of Agricultural and Forest Lands in the National Forests, May 4 , IgI4.

\section{NOTES}

Page 345. The information concerning the American Forestry Association was furnished by Ovid M. Butler, Executive Secretary of the Association.

Page 35I. Extensive hearings were held in Washington and at various Western places during the spring, summer and autumn of 1925 , by a subcommittee of the Committee of Public Lands and Surveys of the Senate of the United States, under a resolution to "investigate all matters relating to National Forests and the Public Domain and their administration." These hearings grew out of the demands of the live stock men for the acquirement of permanent, vested rights for grazing in the National Forests.

Arguments based on needed units for conducting a profitable stock business served to show, both for the National-Forest use and the Public-Domain use desired, that an inventory and classification of the lands by impartial, scientific investigators, would settle definitely many 


\section{THE FOREST LANDS AND CUT-OVER AREAS 355}

of the controversies and would aid in the settlement of border-land cases.

Undoubtedly the live stock business has suffered from an unwise stimulus due to the taking up of homesteads in greater number than could be profitably developed with available grazing land. This is a result of the lack of adequate inventories and proper physical and economic classification of the arid and semi-arid regions of the public domain. 


\section{RECREATION AREAS AND SCENIC ASSETS}

It was not until our population scattered over the wide stretches of the West and concentrated in the congested cities of the East that we began to realize that if we were to have access to the wilderness in the future, there must be a conscious effort to preserve definite wild areas in their natural state. In rgro, Mr. Leopold states that there were six regions in Arizona and New Mexico, ranging in size from half a million to a million acres, where roads did not penetrate, but that commercial enterprise has seen to it that roads traverse all but one of these areas. Of the seven large areas in California ten years ago, all but two have been easily available to the ubiquitous motor. In the Lake regions, fortunately, the wilderness still exists in comparatively large unbroken areas. The Forest Service has pursued a policy of leaving several areas of moderate size untouched by modern roads.

The need for outdoor recreation increases with the density of the population. The United States teems with mountain clubs and other special sports organizations to make possible the enjoyment of the wilderness. More than one hundred and twenty-five national organizations interested in some phase of outdoor recreation were invited in May of 1924 to attend a National Conference on Outdoor Recreation. The President of the United States appointed a committee of several members of his Cabinet who called the conference. An advisory council was appointed from the delegates and an executive committee, headed by Mr. Chauncey J. Hamlin, of Buffalo, has since provided for a series of surveys to inventory and 



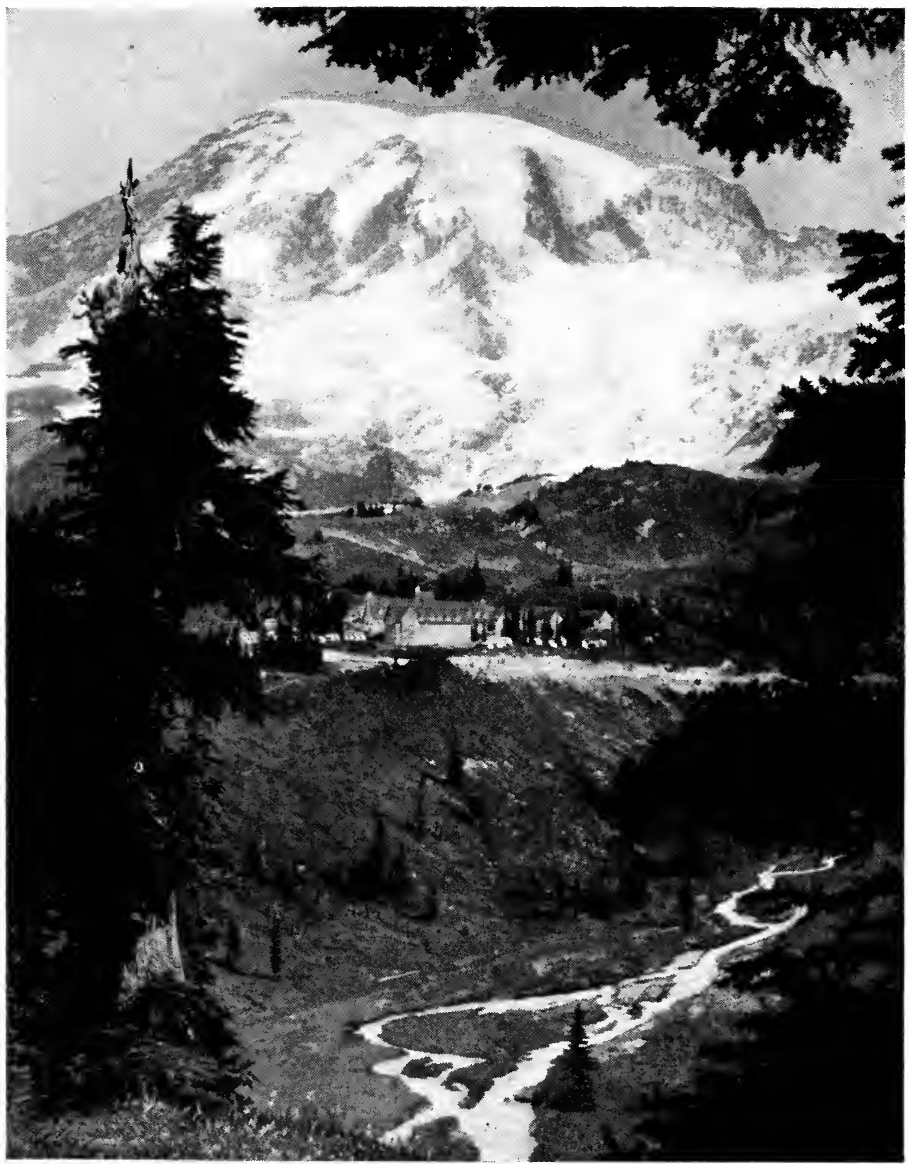

Courtesy of the National Park Service of The Department of the Interior.

Paradise Valley and the Inn, Rainier National Park, with the Mountain and Nisqually Glacier in the background. The Paradise River flows along the floor of the Valley. No one can doubt that the highest use of this land is as a National Park. 
classify the recreational resources of the United States. The lands listed will range all the way from small intensive playgrounds, crowded city parks, to great national parks and play spaces in national forests. The special committees in charge of the surveys are already discovering neglected or little-known areas in public ownership which are eminently suitable for recreation.

Of the principal types of recreation lands, perhaps the national parks may be considered first, since a very definite and valuable policy has developed concerning these lands.

National Parks. - The development of National Parks in the United States may be traced back to the vision of a little group of explorers who visited the Yellowstone in 1870 . The first thought that it would be a "profitable speculation" for the members of the party to take up land surrounding the highlyspectacular geysers and other scenic phenomena was displaced by the proposal that this wonderland should never be allowed to pass into private ownership but should be set aside for the use and enjoyment of all the people. "This," declares Mr. Jenks Cameron, "was the beginning of the "national park idea.' " In 1872 President Grant approved the act passed by Congress to set aside the Yellowstone region "as a public park or pleasuring ground." With this act, too, began the policy of preserving national parks from "injury or spoilation, of all timber, mineral deposits, natural curiosities, or wonders within said park, and their retention in their natural condition."

Nearly twenty years passed before any new areas were set aside by the Congress of the United States as public parks for the use and enjoyment of the people. Then the Sequoia, Yosemite and General Grant National Parks were added in 1890. As other national parks were created from time to time, the Secretary of the Interior was called upon to administer them. In r9r3, Secretary Lane placed an assistant to the Secretary in general charge of park administration. In June, I914, a general superintendent and landscape engineer 
of the national parks was appointed to reside at San Francisco and have general supervision over all park superintendents.

As early as rgro the American Civic Association urged the formation of a National Park Bureau in the Department of the Interior. In 1916, after hearings before three sessions of Congress, the National Park Service Act became a law, with the provision:

"The service thus established shall promote and regulate the use of the Federal areas known as national parks, monuments and reservations hereinafter specified by such means and measures as conform to the fundamental purpose of said parks, monuments, and reservations, which purpose is to conserve the scenery and the natural and historic objects and the wild life therein, and to provide for the enjoyment of the same in such manner and by such means as will leave them unimpaired for the enjoyment of future generations."

It was by this act that "the National Park System came to possess the machinery for its government that it had required for decades."

The Honorable Stephen T. Mather has been the first and only Director of the National Park Service. Under his guidance, policies have been developed, national park areas expanded, and the use of the parks by the people enormously increased. In 1924 there were $8,366,893$ acres in the national parks and monuments, and the national parks were visited in r 925 by $1,760,512$ people as compared to 86,000 in 1909 and 356,000 in r 916 .

The "National Park Idea," from the time of the statement set forth by the Yellowstone party in 1869 to the issuance of the last statement of policy by the Secretary of the Interior in 1925 , has remained essentially the same. Details of administration have been modified, but the principles governing national parks to-day are a crystallization of the principles enunciated half a century ago. But we are developing sharper distinctions between the different sorts of recreation areas.

The American Civic Association a few years ago made an attempt to define National, State and local parks. A National Park was described as being: 



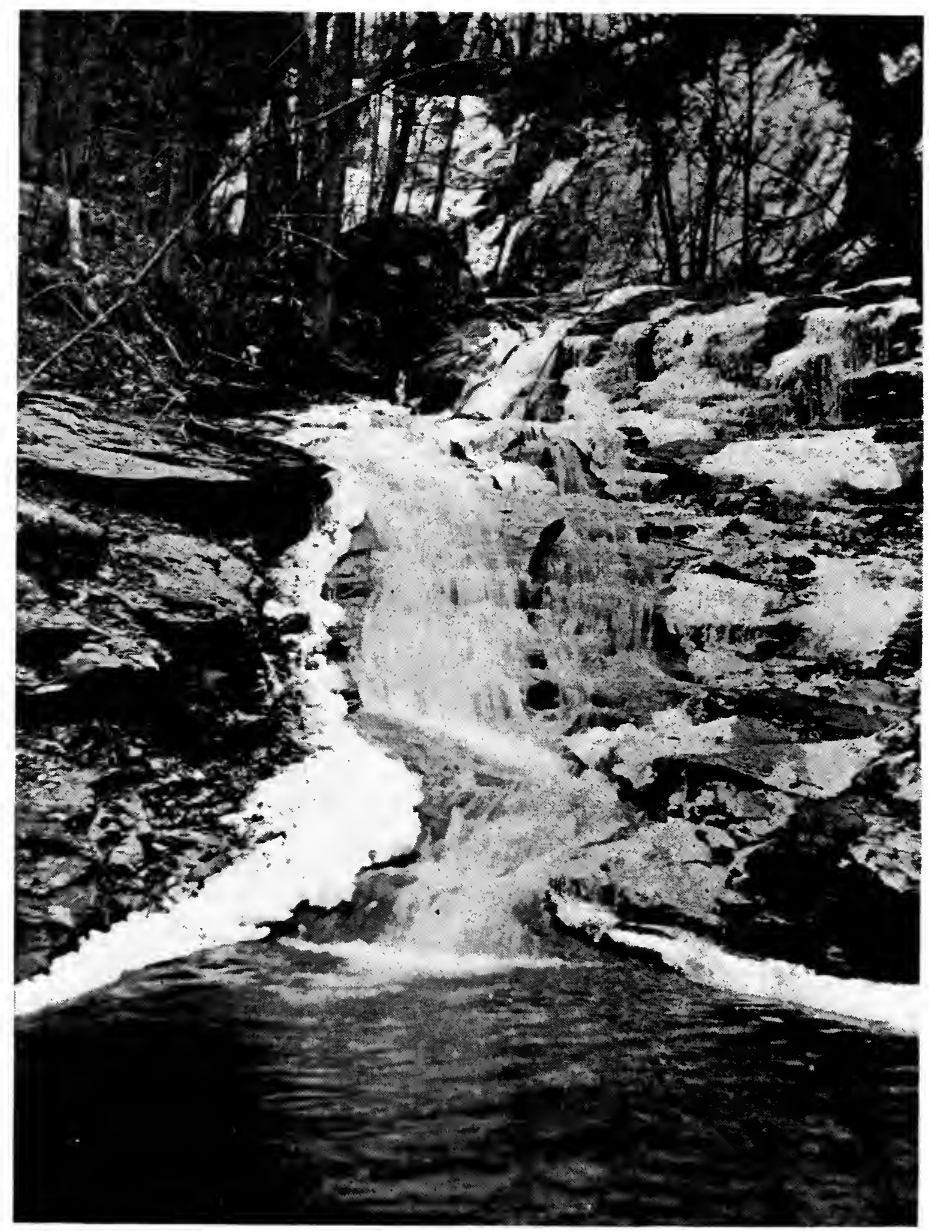

Photograph by Harry Staty, Harrisonburg, I'a.

Falls in the proposed Shenandoah National Park in Virginia. 
"An area of some magnitude distinguished by scenic attractions and natural wonders and beauties which are distinctly national in interest.

"An area in which the public-service value in preserving mountains, valleys, forests, lakes and streams with their characteristic plant and animal life for the 'use and enjoyment of all the people' distinctly outweighs the possible benefit to the few who would profit by commercial uses.

"A National Park possessing these qualifications deserves to be protected jealously and completely from all outside utilitarian and commercial uses."

\section{It was maintained that:}

"As our population grows larger, pressure to permit the introduction into National Parks of utilitarian uses will increase, but it must be noted that all scientific, bealth, esthetic, and spiritual values of proper National Parks, and the social and economic necessity for their general availability will increase in greater proportion. This is true not only because of the increasing demands of a larger and more congested population, but because as that population multiplies, the 'open country' becomes more completely settled and appropriated for utilitarian purposes."

In the hearings before Congress, in defense of the Yellowstone Lake against commercial encroachment, John Barton Payne, then Secretary of the Interior, declared that, "If the National Parks may be encroached upon for a commercial purpose, sooner or later they will be destroyed."

The definition adopted the following year by the Council on National Parks, Forests and Wild Life, followed the same general trend and that set forth by the President's Conference on Outdoor Recreation in 1924 constituted a restatement of these principles in concise form.

The distinction between National Parks and National Monuments is recognized generally. The definition set forth by the American Civic Association is:

"A National Monument is an area, usually of limited size, set aside by the United States Government to preserve some natural wonder or to commemorate some historic event or person of national importance." 
National Monuments, unlike National Parks, may be created by executive order of the President of the United States.

There are still existing in the United States a number of areas which distinctly qualify for the National Park System; the Kings River region in California and the noble Teton Mountains near the Yellowstone are outstanding examples. In the Southern Appalachians a Commission appointed by the Secretary of the Interior has selected an area in the Great Smoky Mountains of North Carolina and Tennessee and an area along the crest of the Blue Ridge Mountains in Virginia as suitable for Eastern National Parks. Since the areas had passed generally into private ownership an organized effort is being made by the people of these States to purchase the parks and present them to the Federal Government as a part of the National Park System.

After careful examination is made through inventory and classification and those areas which qualify have been admitted to the National Park System, the Government should extend a secure protection to all national parks from any sort of commercial exploitation beyond the absolutely necessary provision of facilities to provide for the park visitors.

The National Parks have a value beyond their great recreational resources. They are exceedingly valuable as examples of primitive America. The natural museums now being established in the national parks by the American Association of Museums will extend the opportunities for education of the people concerning the plant and animal life.

The National Parks constitute a distinct class of use for lands, not because they are administered by the National Government, but because they meet a great popular demand for closely-protected areas which meet a standard set up so carefully that only a few regions can properly qualify.

Recreation Areas in the National Forests.-One of the important incidental uses of the National Forests is that of recreation. In the National Parks recreation must always be subordinated to the preservation and protection of the 
scenic assets and wild life. This may result in a closer supervision of visitors and more complete regulation than will be necessary in the recreational use of the National Forests. Particularly, there may be always a greater freedom for sportsmen after fish and game in the National Forests than should be possible in the National Parks. For the simple enjoyment of outdoor life, not necessarily in contact with the supreme scenic spots of the country, but often in very stately forests, the National Forests offer large areas, especially along the many streams which cascade down the mountain sides and into wooded valleys. "Recreation," declares Colonel Greeley in his 1925 annual report, "under proper safeguards and supervision, is wholly compatible with timber production and watershed protection and may properly be planned for in systematic forest management." Already there are within the National Forests some I 500 spaces designated as public camp grounds, part of which are furnished with simple facilities. The wide extension of roads and trails in recent years has opened very large areas to the public for outdoor recreation.

As the years go on the boundaries between the National Parks and the National Forests are being adjusted along lines which lend themselves to convenient administration and which, in the last analysis, will result in the assignment of appropriate areas to each Service.

State Parks and Reservations.-In general the residents of the Union have been more State-conscious in matters of pride than in initiative and responsibility for developing State policies in regard to the State's possessions.

It may be remembered that the city park idea developed rather slowly during the nineteenth century. The first true National Park was created in 1872 when the Yellowstone was set aside for the enjoyment of the people; but for more than a quarter of a century after that no new national parks were created. Except for one or two false starts, State Parks have even a more recent origin. The States have owned certain historical monuments or memorials, usually to commemorate 
some battle or hero; but State-owned lands dedicated to recreation purposes have been developed within the memory of those now living.

Curiously enough it was not in a region with a large population crowded into cities that the first start was made. In I878, when the State of Wisconsin was still sparsely settled, an enabling act was passed to set aside some 50,000 acres of State-owned land for park purposes. But in 1897 a shortsighted Legislature repealed the law and sold 32,000 acres. In the meantime in 1895 the Interstate Park was purchased. A State Park Board, appointed under the law of 1907, employed Mr. John Nolen, Landscape Architect, to report on "appropriate places for the establishment of State parks." Wisconsin, with all its open spaces, has actually been obliged to purchase some 8,000 acres and has received by gift perhaps 6,000 acres more.

In Massachusetts in 1892 a body of public-spirited men petitioned the legislature that an inquiry be instituted for the purpose of discovering ways and means to make available to the general public recreation areas, since the "seashores, the river banks, the mountain tops, and almost all the finest parts of the natural scenery of Massachusetts are possessed by private persons, whose private interests often dictate the destruction of said scenery or the exclusion of the public from the enjoyment thereof." The agent appointed under the law stated that he "found leagues and leagues together of shoreline to be all private holdings, without the intervention, in these long reaches, of a rod of space on the shore to which the public has a right to go." In the thirty years and more which have elapsed since then, Massachusetts has appropriated money directly for purchase of park lands, has appointed commissions, like the Metropolitan Park Commission, and has created a Board entitled the Trustees of Public Reservations. In the reservations there are now more than 12,000 acres of land, including some of the finest mountain tops in the State. 



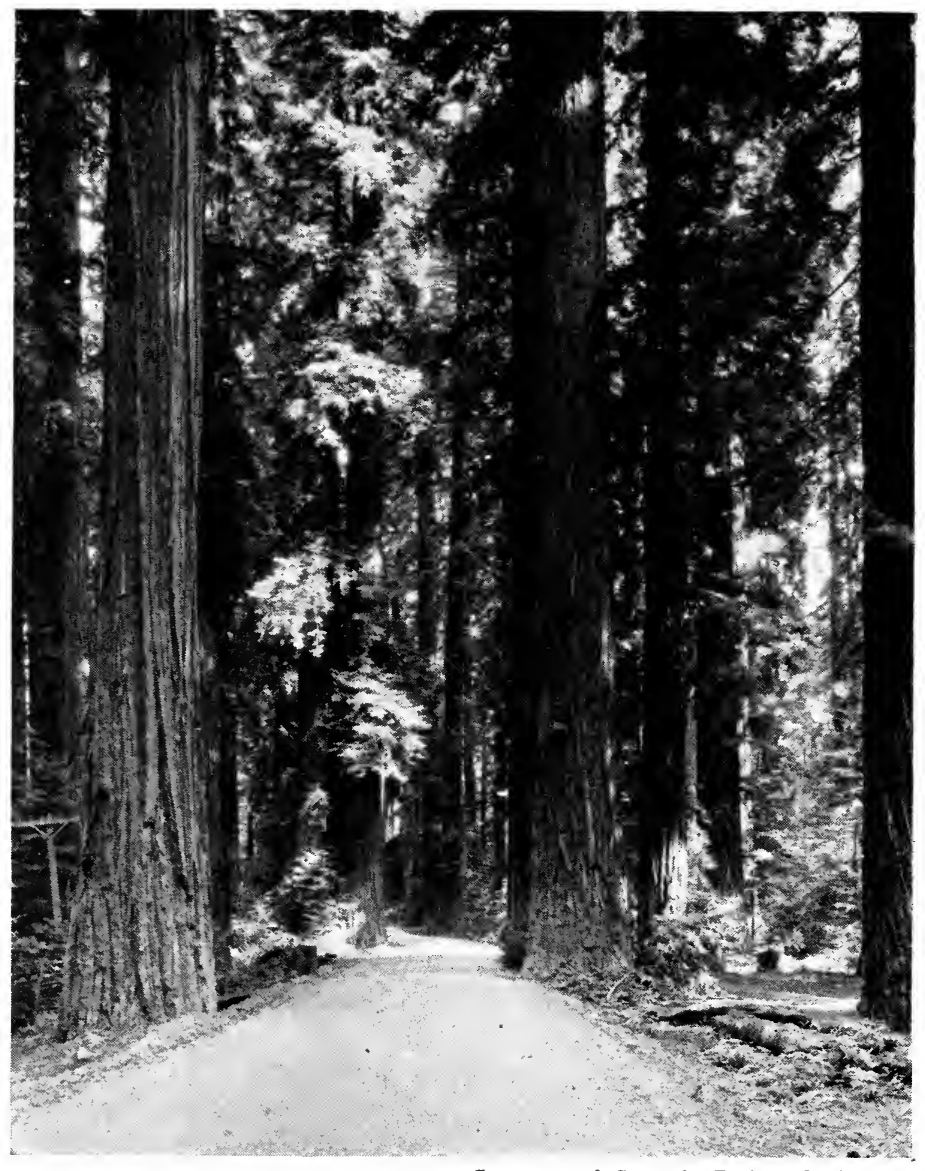

Courtesy of Save-the-Redwoods League.

California Redwoods which may be preserved in a State Park System. 
The Metropolitan Park Commissioners have secured excellent beach properties near Boston.

The five lakes established as canal reservoirs in $I 830$ to 1840 by the Ohio General Assembly were dedicated as parks in 1896. In Minnesota in I891 and in California in 1895 State Parks were created. A public-spirited movement called "The Save the Redwoods League" has been mobilizing private and public resources to save some of the fine remnants of these stately giants for the pleasure and education of posterity. An effort is being made to acquire areas to build up a balanced system of State Parks connected by adequate highways.

The State Park movement in the modern sense began with the establishment of the Palisades Interstate Park in New York and New Jersey so far as these States are concerned. There had been in New York before this date a number of historical memorials, but no extensive recreation parks. Niagara Falls Reservation had been authorized by the act of 1883 and might be considered a precedent, though the Falls are more in the nature of a scenic wonder than a country recreation area.

In some respects the Palisades Interstate Park is the most dramatic of all the State Parks - not because of its scenery, though the wooded hills and rocky cliffs overlooking the picturesque Hudson River are very inspiring, but because more than 35,000 acres of untouched country is made accessible to the ten million people who live in the immediate vicinity. Many thousands of residents of Manhattan may cross the river by ferry and in the strip of land below the Palisades along the river front they may safely cook their suppers out of doors. The new bridge recently opened makes Bear Mountain easily accessible by automobile to the residents of New York. The summer vacation trip will always remain a pleasant experience for those who can afford it; but it is the opportunity for every-evening and week-end excursions which forms the habit of outdoor recreation. The foresight which has defi- 
nitely reserved the Palisades Interstate Park for the use and enjoyment of the people of New York and New Jersey for all time cannot be too highly commended. The automobile has lengthened the range of the people who can live in the environs and do business in New York City or in the nest of cities which have grown up around it. It is predicted that in 1950, $16,000,000$ people will be living in the area now occupied by I0,000,000 people. There may be larger and more beautiful State Parks, though the Hudson River scenery and the Storm King road have a more than local reputation, but surely there will be no park in the United States more used and enjoyed by those who need outdoor recreation than the Interstate Palisades Park of New York and New Jersey.

The State of New York has acquired in recent years a number of very charming State Parks, such as Watkins Glen, Enfield Falls, Letchworth, St. Lawrence and Allegany State Parks. By far the most extensive recreation areas, however, lie in the Forest Preserves in the Adirondacks and the Catskills where nearly two million acres have been acquired. But the people of New York are not satisfied with their present holdings. They know that their population is increasing. It is estimated that by 1940 , now less than fifteen years away, the population of the State will be I4,000,000. The New York State Park Association was formed to carry on the work so well begun. In 1924 the Association published a report on "The State Park Plan for New York, revised to show progress to date with the proposal for the new park bond issue." As a result of this and other sentiment a bond issue was authorized by the last legislature and confirmed by referendum of the people. Moreover, the so-called water power amendment to the State constitution to permit the building of hydro-electric power plants on forest lands owned by the State within the Forest Preserve, was defeated.

Connecticut, Illinois, Indiana, Iowa and Michigan all have well established State Park systems. Many other States have one or more State Parks. By 1950 it is safe to predict that 



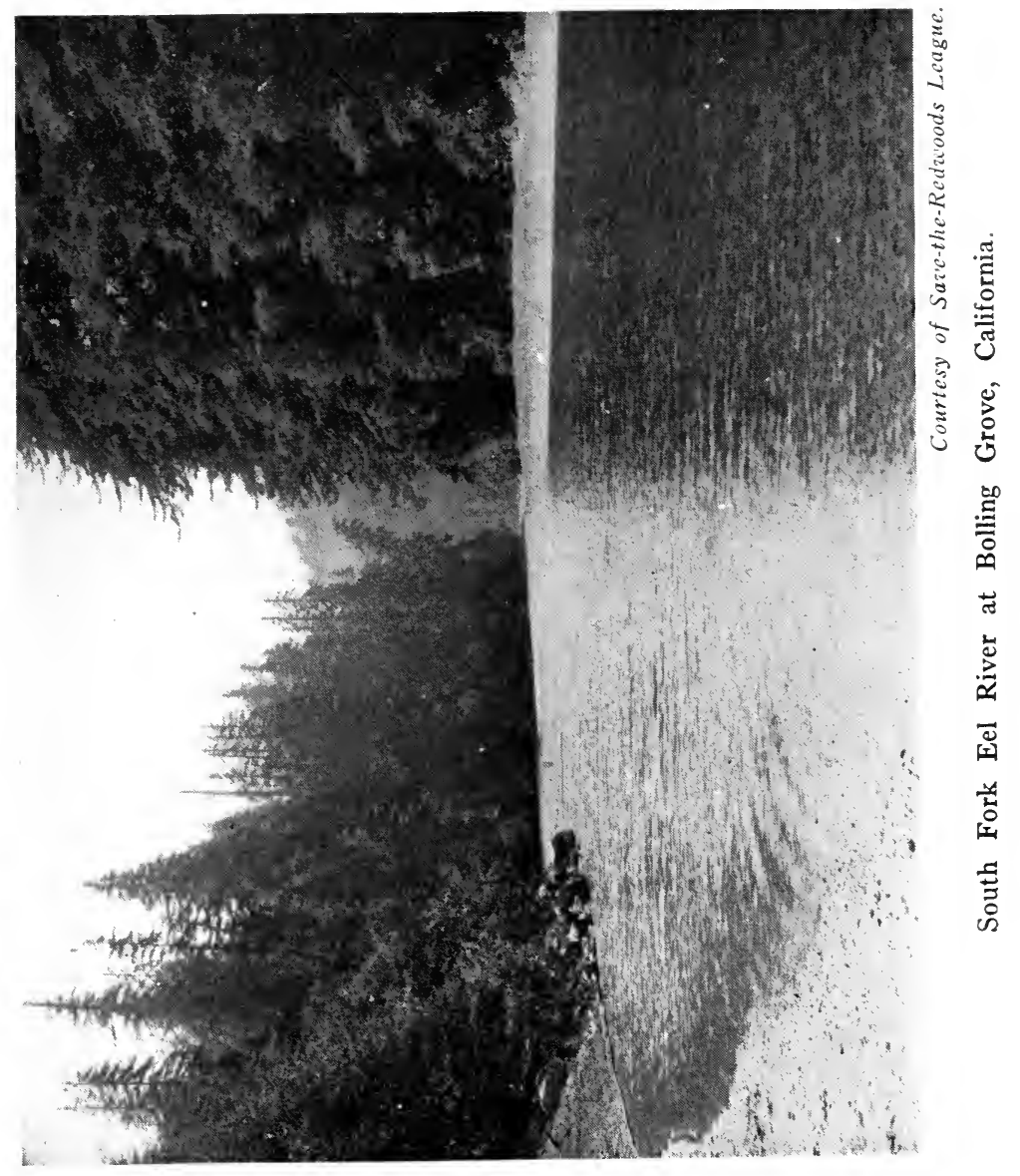




\section{RECREATION AREAS AND SCENIC ASSETS 365}

every State in the Union will be in possession of recreation areas for its residents.

In order to promote State Parks and afford an opportunity for exchange of experience, the National Conference on State Parks was organized at Des Moines, Iowa, in January of I92 I. Under the leadership of John Barton Payne, with Beatrice Ward as Secretary, the conference has met successively at Bear Mountain Inn in the Palisades Interstate Park, at Turkey Run State Park in Indiana, at Gettysburg, Pennsylvania, at Skyland, Virginia, and Hot Springs, Arkansas. The Conference has given direction and impetus to the State Park movement. It has also contributed a forum for the discussion of policies.

An attempt to classify existing State Parks by the American Civic Association resulted in a characterization of five distinct groups-Recreation areas, Scenic areas, Forest Preserve areas, Wayside Parks and Historical Memorials. Mr. Richard Lieber, Director of the Department of Conservation of the State of Indiana, has more recently suggested that there be State Park Reserves, large natural areas available for "roughing it," for camping and outings; State Park Monuments, historic and scenic spots of limited area and use; State Park Memorials, scenic tracts or buildings preserved in memory of persons or events; and State Parks, areas whose primary purpose is the preservation of a portion of the soil of the commonwealth, of natural beauty and significance in unspoiled primitiveness.

As yet we have not seen extensive development of scenic roads and parkways to connect the State Parks. In the Metropolitan Park Systems these parkways have been brought to a high state of development. Undoubtedly the States will develop many such parkways.

It will be perfectly clear, also, that a State Park System should be built in careful relationship to other recreational areas available, such as Municipal Forests, Metropolitan Park 
systems, State Forest Preserves, and National Parks and Forests which may lie within the State.

The principles of planning will need to be applied if the land is to be put in each case to the use for which it is best suited. Those States which have been fortunate enough to dedicate State and Federal public lands to park purposes have been able to make an inexpensive start. But most of the State Parks were created after the public lands had pretty generally passed into private ownership. The taxpayers were, therefore, called upon to appropriate money for the purchase of State Parks. Purchases have been supplemented by many generous gifts on the part of the owners or on the part of groups of people who have contributed toward the purchase of areas to be turned over to the State.

In many State Parks there are hotels. In practically all there are camping grounds. A few of these are operated directly by the State. But most of the Hotels are operated by concessions. The Inn at Turkey Run State Park in Indiana was built and is owned by the State, but it is operated by concession. On the other hand, Bear Mountain Inn is operated directly by the Commission. In some camps there is a fee. Others give free service. Most of the beaches are free; but there is often a bath house where there is a charge for dressing rooms and other service. None of these policies is standardized and perhaps they should not be. Conditions vary widely. But whether we come to the time when great numbers of people are accommodated with recreation facilities for hours or for days and weeks through a direct service of the State or through the system of concessions, we must recognize that it is a serious business to make sure that the sanitary requirements are all met. The unspoiled country is soon ruined by the use of careless visitors who find no provisions for keeping the place clean.

Rural Recreation Spaces.-There is coming to be a demand for rural recreation parks for the use of the neighborhood as distinguished from automobile camps for the use of 



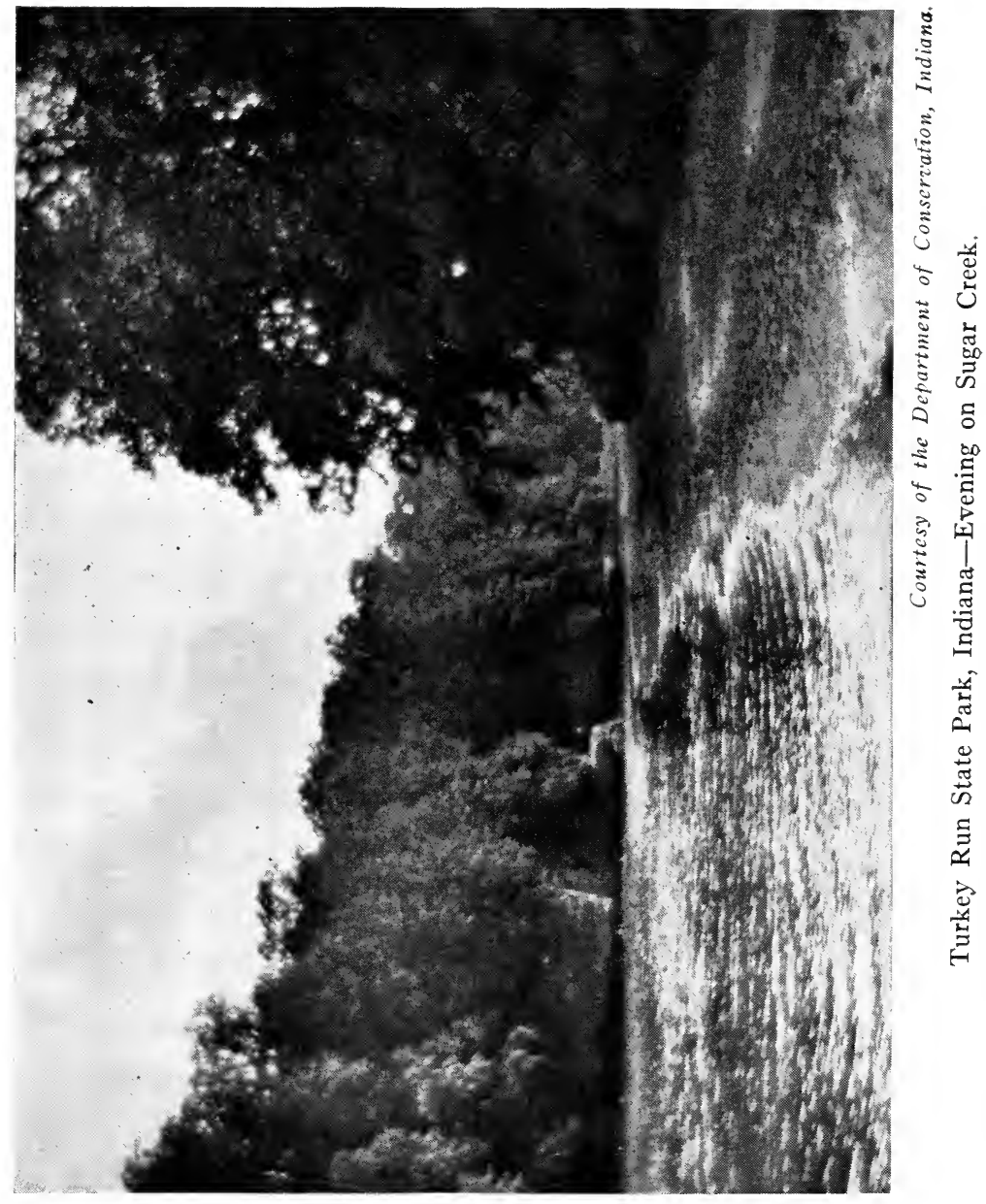


visitors and travelers. There is every reason why scenic spots and picnic grounds should be preserved for farmers and their families. Who has greater need for recreation and social intercourse? With more complete use of every inch of arable land there is little space on the farm for outdoor recreation. "Why," inquires Mr. Wayne Nason, "should country people, in a business partnership with nature itself, have to go to town to enjoy the pleasures of a park? Why should farm families have to go to some one's private grove or lake front for a picnic? Why should farm boys and girls have to go to the town athletic field or playground, in which they have no sense of ownership, for baseball, basketball, or athletic games and sports?" Examples of such rural parks are not lacking. There is Holland Glen in Massachusetts, "carpeted with a profuse growth of moss and ferns and such flowers as laurel, anemone, trailing arbutus, hepatica, trillium, and dog-tooth violets," a bit of primeval forest of hemlock, pine, birch, oak, ash and beech trees.

The possibilities for developing local rural recreation spaces to supplement the city park systems, the State park systems, the National Park and recreation areas in the National Forests, can readily be seen. But again, inventory and classification of lands should precede definite assignments for use.

Co-ordination of National, State and Local Planning. -But all these various National, State and local programs for the widely divergent uses of land for recreational purposes are to be applied to one map. When a National Park is created it naturally serves the immediate vicinity as a local park in some degree no matter how outstanding its features may be. A State Park is not needed to serve exactly the same population. In other words State Park systems should be built up with due regard for all other recreation areas in the State. This is equally true of county and regional parks. State Parks should supplement, not duplicate these spaces.

Mr. Warren H. Manning has proposed "continuously connected units of highest scenic values but of widely varying 
widths to be called National Park Ways to pass through or branch out to all kinds of public holdings, with takings always wide enough for all future trails, bridle paths, pleasure trafic roads, but with little or no heavy truck traffic."

If State Park-to-Park Highways become popular one can imagine not only the development of the National Park-toPark Highway by some such plan, but its amplification through the various commonwealths of the Union.

\section{SUGGESTED READING}

ALdo LEOPOLD, "Wilderness as a Form of Land Use," in The Journal of Land and Public Utility Economics, October, 1925.

Jenks Cameron, The National Park Service, its History, Activities and Organization, Service Monographs of the United States Government No. II. Issued by the Institute for Government Research, 1922.

American Civic Association, National Parks, by Honorable William H. Taft, Viscount James Bryce, Honorable Walter L. Fisher, and J. Horace McFarland.

First Annual Report of the Director of the National Park Service to the Secretary of the Interior, I917. Also Annual Report for 1925. American Civic Association's Park Primer, What Everybody Should Know About Parks, 1922.

National Conference on Outdoor Recreation, Proceedings, Washington, May 22, 23 and 24, 1924. Resolutions reprinted in Civic Comment, issued by the American Civic Association, June 28, 1924.

National Parks Commitree (now Council on National Parks, Forests, and Wild Life), A Policy for National and State Parks, Forests and Game Refuges, I923.

JoHn Nolen, State Parks for Wisconsin.

RICHARD LIEBer, "What is a State Park?" in Parks and Recreation, November-December, 1925.

James L. Greenleaf, "The Trend of the State Park Movement," in American Forests and Forest Life, November, 1925.

Wayne C. Nason, Rural Planning-the Social Aspects, Farmers' Bulletin No. 1325 .

Wayne C. Nason, Rural Planning-The Social Aspects of Recreation Spaces, Farmers' Bulletin No. 1388.

Warren H. Manning, "A National Park System," in Parks and Recreation, January-February, 1924. Also reprinted. 


\section{NOTES}

Page 359. The definitions set forth in the booklet entitled "A Policy for National and State Parks, Forests and Game Refuges," issued by the Council on National Parks, Forests and Wild Life, involve fundamental land policies. The Committee saw clearly that:

"Any policy dealing with National and State parks, forests, and game refuges must be, at bottom, a land policy. To be sound, it must rest upon the use of the entire land in the country for the purposes to which each portion of it is best suited in filling the essential needs of the people. These needs include not only the material measurable ones, food and shelter, but the intangible spiritual ones which come under the head of recreation. . . .

"The tendency is for land eventually to be used for the needs to which it is best suited, but this too often comes about only after a long and wasteful process of trial and error, during which there is much unnecessary suffering, and enormous values in natural resources are permanently destroyed. Among the values so destroyed are not only the natural plants and animals so necessary to science and education, but recreational features, including fish and game, together with vast quantities of timber and minerals. Hence the need for a sound land poiicy covering National and State parks, forests, and game refuges, as well as other lands.

"Whenever a particular area of publicly owned land could be put to one of several conflicting uses, a decision as to which use shall prevail ought obviously to be made in accordance with a consistent policy based on the public interest. Without such a policy there will be a continuance of the present struggle between those who wish to develop and consume all natural resources as rapidly as possible, often regardless of the future, and those who want to make parks wherever possible, regardless of legitimate needs for the resources which would thereby be withdrawn from use. The former argue that the general welfare requires the opening up of all regions to their fullest economic use; the latter accuse their opponents of selfish materialism, and claim that the public has a right to do as it pleases with its land and resources. There is danger from both sides. The over-rapid exploitation of new regions in the past has brought a reaction which is reflected in the strong sentiment for parks and in an often-times vague desire to preserve everything, regardless of legitimate needs. It is important to find a solution which can form the basis of a sound public policy.

"Among the more important provisions of a sound policy are the acquisition by the public of privately-owned lands wherever their best use would be for parks, forests, or game refuges, and preventing or discouraging private owners from using their lands in ways which are seriously prejudicial to the public interest."

Mr. John Nolen summarized the requirements:

Page 366. In 1908, speaking particularly of recreational State Parks,

"(I) They should be large; otherwise they could not be used by great numbers of people without destruction of the very qualities most essential to their purpose. On account of the influence of 
topographical features it is hardly practicable, nor is it necessary, to fix an acreage for State Parks, but, as a working basis, it may be said that it is desirable that State Parks should contain at least two or three thousand acres and five thousand are even better. (2) State Parks should be accessible-not to the degree that city parks are, but accessible by train or boat or vehicle within reasonable time and at reasonable expense. Accessibility, however, should not be interpreted too narrowly, nor should it be measured by present facilities alone. The establishment of a park in one section or another will inevitably lead to an increase of travelling accommodations, as will also the mere lapse of years, bringing with it an increased density of population. (3) The air and climate of sections within which State Parks are located should be salubrious, and the situation healthful. Especially should the climate of the summer months, the period that most people have for vacations, be agreeable. In the course of years State Parks are likely to be more or less visited at all seasons, as Nature offers a reward in every month to her visitors. But the emphasis for the present must fall on the mid-summer season with some consideration for spring and autumn.

(4) The property for State Parks should be reasonable in cost. Cities average about a thousand dollars an acre for park land, but hope for a comprehensive system of State Parks must be founded on a much lower cost, and except in the case of densely populated States, States that have waited too long before taking action, there is every prospect of securing the most suitable and fit land at almost nominal rates. The parks acquired by States so far have not averaged in cost much more than twenty-five dollars an acre, I believe. Seldom would a State be justified in paying an average of over a hundred dollars an acre for a tract of any considerable size. Not only should the first cost be low but the property should be of such a character as to require relatively small expenditures for construction and maintenance. It should be a "natural" park, one of such intrinsic beauty as to require little outlay for improvements (except for roads, paths and other features necessary to its use) and upkeep. (5) Finally, the site for a State Park should, above all, have a decidedly uncommon charm and beauty, a distinction among landscapes, an irresistible appeal to the Nature lover. Here should be no room for doubt, for failure in this point means complete failure; and on no other point, nor on all other points together, can justification rest. State Parks must be unmistakably beautiful; they must present to the enjoyment of all some consistent, unspoiled type of landscape; they must offer freely the glory of lake or mountain, the picturesqueness of shore or bluff, the beauty of hill and vale."

While Mr. Nolen, in setting forth these requirements, had particularly in mind the State of Wisconsin, they stand to-day as an excellent outline of characteristics which it is desirable that recreational State Parks should possess.

Page 367. Mr. Warren H. Manning, in his article on A National Park System, has elaborated the idea of connecting National Park Ways:

"These Scenic Ways will include and extend existing units now administered to give the greatest pleasure and benefit to those whose 
recreation comes from viewing, tramping, and camping in landscapes where all wild life is protected from man's destruction or injury. As wild life sanctuaries, such ways and units will help to feed adjacent National Forests and Game Preserves in which the most fit use will come from the economic values of growing and harvesting timber, and propagating wild life for food, with the pleasures of controlled hunting or fishing.

"Other connections will be made to National Monuments or other places of historic, ethnological, and scientific interests, in which scenic values may be of minor importance. Enough land should also be held for continuous public trails or roads along the shores or bluffs of existing lakes and the basins where artificial lakes should be established for the full utilization of our falling waters for producing power and for use in irrigation and domestic water supplies.

"Such a National Park System will carry a huge traffic and greatly relieve the commercial truck ways and tracks, but to be adequate it must find its way around and not through cities. Many cities would have conveniently accessible connections over existing State, county, and town park systems and reservations."

\section{Mr. Manning analyzes the surface of the United States.}

"About one-ninth of our lands are below the 500 foot elevation. The valleys of the Connecticut, Hudson River, Lake Champlain and the Mohawk from the Hudson to the Great Lakes, the Susquehanna for much of the way toward a connection with the Genesee, all form extremely important passes through the Allegheny Mountain Systems to the Great Lakes and the St. Lawrence River Valley. The Illinois River arm of the Mississippi keeps within this 500 foot level nearly to the Des Plaines River through which canal connection is now made to the Great Lakes. The most of the Ohio and Wabash River valleys are within this level. Passing into or through this district are fifty rivers that are navigable to boats of threefoot draft, some to only a few miles from the sea, the MississippiMissouri River for over 2500 miles. Most of the Atlantic and Gulf rivers enter the inter-coastal navigation way that is, or can be, opened nearly all the distance from Boston, Mass., to the Mexican line, a water way that is not duplicated elsewhere in the world. . . .

"Within the 500 to 1000 foot elevation lies much of the Mississippl and Missouri Rivers and their tributaries, the Great Lakes, the Red River of the North, and Hudson Bay in Canada. . . . The scenic values of this region come from wide rivers and their high bluffs, the Great Lakes shores and cliffs, a multitude of lakes and the wide sweeps of the prairies. The National Park Way connections here cannot be given over as fully to recreation uses as they can above 5000 feet.

"Above 1000 feet are the New England and New York mountain masses, the Appalachian Mountain ridge from New York to Northern Georgia and Alabama, the Ozarks of Arkansas, Missouri and Oklahoma and the Great Western Plateau. The Ozarks, the only mountain masses in the lower Mississippi Valley, have great recreation values for a wide territory. The great Western Plateau, between elevations 2000 and 5000 feet, includes one-eighth of the area of the United States. ... 


\section{LAND PLANNING IN THE UNITED STATES}

"The Pacific Coast Range of mountains forms the western edge of the great Western Plateau. About 673,700 square miles of this area (one-fourth of the area of the United States) lies 5000 feet above the sea, and carries snow-capped ridges and peaks above 10,000 feet, and near its southerly edge are hot deserts that lie below the level of the sea....

"It is in the regions above 2000 feet that the scenic and recreation values of forests, water storage, and mountain masses are dominant, and in which the major part of our public holdings in forest, especially in the West, now lie." 


\section{THE WATER RESOURCES OF THE UNITED STATES}

"For generations," declares Herbert Hoover, Secretary of Commerce, "we have driven our energies in the development of land. We have done a great job. We have done comparatively little with our water resourçes. To-day we must speed the development of our water in its aid to the land-power, irrigation, and above all, transportation. This will test our vision and our statesmanship. For we must consider these questions not alone in the light of the needs of to-day, but of those beyond our time and generation."

We found the immobility of land to be one of its controlling characteristics. It is in the movement of water that we find the greatest resources. City water supplies flow down from the heights, by gravity where possible, and, if necessary, are lifted by pumps to storage reservoirs to give pressure or "head" to the water supply for people on the hills or in high buildings. The water which we drink in any metropolitan center may have come from watersheds situated at a greater distance than the milk collected from the farmers and transported by rail or truck over considerable areas. There is frequently keen competition between enterprising towns for development of public water supplies and the establishment of adequate storage reservoirs outside the town limits. On the western prairies, a town may be recognized across the level fields by the inevitable water tank which is filled by pumping artesian water from the bowels of the earth. But operations far distant from the point of consumption may disturb or divert subterranean flows of water and deprive entire communities of a 
water supply thought to be constant. Only too often has the whole problem of distribution of water for cities, towns and

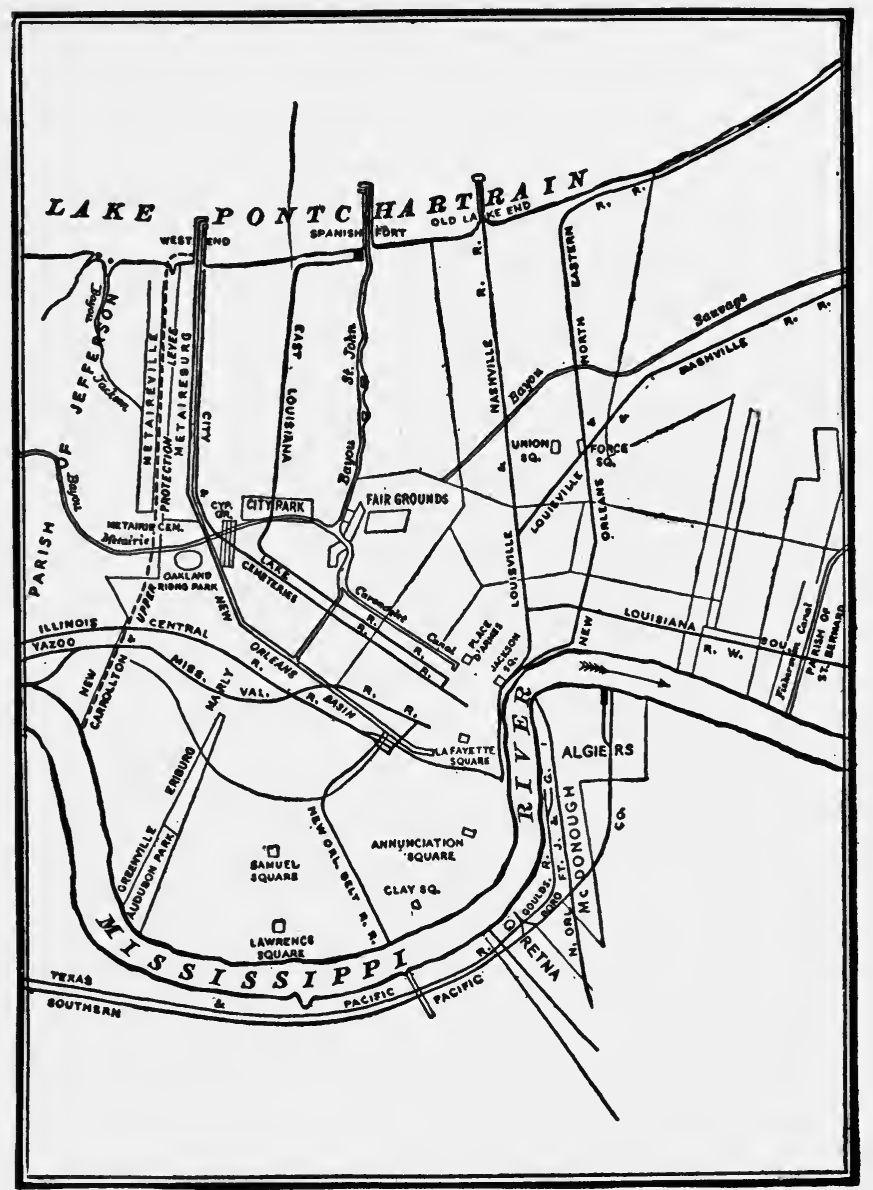

New Orleans, with its extensive waterfront, may be connected by inland waterway with the Great Lakes.

rural communities, been left entirely to the initiative of each local group, with no effort to effect an equitable supply for the entire country. As the density of population increases 
the need for planning water supplies for entire regions in the public interest will become more apparent. In no field is adequate planning more needed.

As a part of a general inventory of our water resources, the needs of the population for water for domestic uses and the conduct of industry will play an important part. While the use of water for drinking purposes, in theory and sometimes in organic law, ranks as a preferred primary use, we hear much more about inventories for power and for navigation than we do of a thorough-going national inventory of the water-supply resources of our country.

Navigation. We are undoubtedly entering a period of great revival and expansion of our navigable streams. For a time the railways superseded and, to some extent, displaced highway travel. But in the last decade the highways have recovered and transcended their old importance. During the next decade there is every indication that the waterways of the United States will recover and far outstrip the water-borne traffic of any previous period. Mr. Warren $\mathrm{H}$. Manning has outlined the bulk of our river-borne traffic possibilities.

"To our Atlantic and Gulf Coasts come over fifty navigable rivers, and to the Pacific Coast, five. About $20 \%$ of the navigable streams and their harbors are kept in condition for all season's use. Altogether we have about 26,000 miles of navigable river channels up to 3 -foot depths. Rivers and canals will come into more general use as in European countries to supplement and relieve the railroads that put the most of this water traffic out of use a generation ago. There are about roo canals. Forty-six of these, with a length of 2200 miles, are in use. Thirty-one, with a length of 2450 miles have been abandoned. Twenty canals are proposed with a total length of 1500 miles."

Mr. Hoover urges a re-inventory of the resources of our inland waterways. He visualizes the Mississippi System as 9000 miles of connected waterways, with, perhaps, 3100 miles of trunk lines and 6000 miles of laterals, extending from New Orleans to Chicago, a great north-and-south water highway 


\section{LAND PLANNING IN THE UNITED STATES}

system connecting the Gulf of Mexico with the Great Lakes. He believes that a great east-and-west trunk line of I 600 miles, from Pittsburgh, through Cairo, to Kansas City, will be brought into active use. With great feeders, through the Tennessee, the Cumberland, the Arkansas, the upper Missouri, the upper Mississippi, the Monongahela, the Allegheny and others, the great interior of the agricultural country could be brought into cheaper and closer communication with the centers of consumption.

The great advance of mechanical appliances, the possibilities of new discoveries and the application of known principles, will bring about "great improvement in design and size of water craft, in methods of propulsion, and in loading and discharging cargoes."

The obstacle which has limited the usefulness of river traffic more than any other, perhaps, has been the existence of fragmentary units. The towns of the great Mississippi Valley are not in fact connected to any great extent by navigable waterways. They are separated by the shallow sections. Only through careful inventories of our resources, classified into priority groups based on economic needs, can the actual operations be undertaken to create great navigation routes of national importance.

There are at least two projects under consideration to-day to bring the Great Lakes with their enormous freight traffic into direct communication with the Atlantic Ocean boats and so prevent the expensive and time-consuming trans-shipment necessary to bridge the shallower waterways where neither the Great Lake boats nor the ocean freighters can penetrate.

Mr. Manning points to the great future benefits to be derived from the "protected inter-coastal canal," providing for traffic not far inside of the Atlantic and Gulf Coast lines for all the distance from Boston to Galveston. Much of it already exists, but with improved channels and through connections, no other country in the world could count such a resource. 
Fortunately, rivers, "capable of carrying commerce of a substantial and permanent character," fall within the jurisdiction of the United States if the Federal Government cares to exercise its authority. The legal difficulties in developing a National Plan for bringing into use our navigable streams for freight transportation appear to be comparatively simple. Mr. Hoover believes that there is now sound economic incentive to justify a broad national program which can be put into execution with great benefit to the producers and consumers of the country.

The articulation of water and rail routes in the carrying of traffic presents another nice problem in comprehensive national planning. The inland waterways, far from forming competitive systems with the rail carriers, will supplement the railways and with them form a service to the people of the United States which will provide more efficient and cheaper transportation. It should not be many years before the co-ordination of inland waterways and rail shipments will be as complete as the oceanrail traffic. But these desirable ends can be secured only through adequate planning.

The question of ownership in the waters of inland streams turns on the determination of navigability. For purposes of the United States Government, the test is as to whether a stream is capable of carrying commerce of a substantial and permanent character. But much confusion exists in the status of ownership in streams which are not in law navigable, and frequently the ownership in the bed of the stream is different from that in the waters. While the variations in the laws controlling ownership in the water resources of the country have a bearing on the possibilities for comprehensive planning for their use, it is not necessary here to discuss in detail the forty-eight varieties of laws and the infinite shades of interpretation through court decisions. Suffice it to say that there are no insuperable obstacles to adequate planning, though the legal status of water resources should undoubtedly be included in the inventories. 


\section{LAND PLANNING IN THE UNITED STATES}

Water Power.-The total capacity of water wheels installed in plants of roo horsepower or more in the United States in March, I925, was 10,038,655 horsepower, an increase of ten per cent over the total in March of 1924 . The potential water power resources of the United States are estimated to be about $35,000,000$ horsepower available 90 per cent of the time and 55,000,000 available half the time. In New England more than half of the potential power is already in use but in the mountains of New York and Pennsylvania, in the South and in the West only a small proportion of possible power development has taken place.

Power uses of water, fortunately, may be co-ordinated with many other uses, so that in the future we may look forward to a very full realization of the beneficial results to come from development and transmission of power to manufacturing and domestic uses. The development of power through dams, pipes and other paraphernalia, is held to be a conflicting use of the National Parks. Therefore, in appraising areas to come into the National Park system it is important to determine at the outset whether the most beneficial use for all the people would be for a National Park or for the development of power. The power use of streams is not necessarily incompatible with recreation as it is conducted in the National Forests or in other open spaces. The conflict with the National Parks comes from the standards set up to protect in their natural state the areas selected for future generations and the need for a highlyunified administration which will insure a single control and an adequate protection from all commercial uses except those actually necessary to park utilization.

Under the Federal Power Commission Act of 1920, the Secretary of War, the Secretary of the Interior and the Secretary of Agriculture sit as a Commission on Federal Water Power. The Commission was authorized to make investigations and collect and record data "concerning the utilization of the water resources of any region to be developed, the water power industry and its relation to other industries and to inter- 


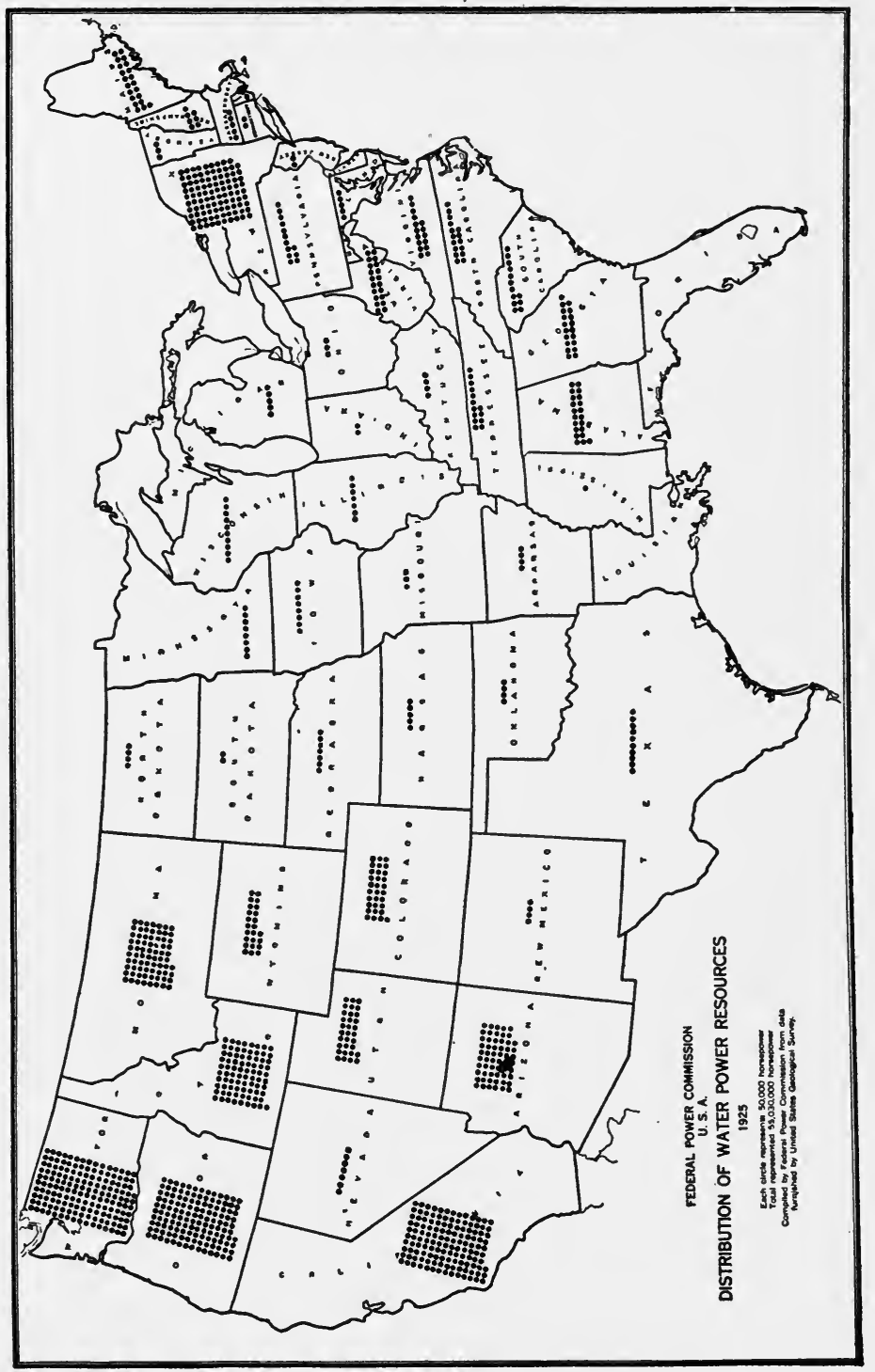


state or foreign commerce, and concerning the location, capacity, development costs, and relation to markets of power sites, and whether the power from Government dams can be advantageously used by the United States for its public purposes, and what is a fair value of such power." The Commission has been hampered by lack of funds, but the enabling act is really a planning act in the true sense of the word. The results of investigations of the Power Commission, taken into account with the results of investigations of other special bodies should make available data which would lead to the proper assignment of uses in the interests of all the people of any given area.

The Federal Power Commission was also empowered to "issue licenses to citizens of the United States, or to any association of such citizens, or to any corporation organized under the laws of the United States or any State thereof, or to any State, or municipality for the purposes of constructing, operating, and maintaining dams, water conduits, reservoirs, power houses, transmission lines, or other project works necessary or convenient for the development and improvement of navigation, and for the development, transmission, and utilization of power across, along, from or in any of the navigable waters of the United States, or upon any part of the public lands and reservations of the United States (including the Territories), or for the purpose of utilizing the surplus water or water power from any Government dam," with certain other special provisions. The Commission has authority to prescribe the rules and regulations for the establishment of a system of accounts by the licensees. The licenses are issued for a period not to exceed fifty years. Therefore, if the policy of the Government should be to effect a public ownership and operation of water power, it would be possible gradually to bring power plants back into direct Government control. In the meantime, the Federal Power Commission may exercise supervision over State, municipal and private holders of licenses.

In recognition of the standards set up and generally accepted 


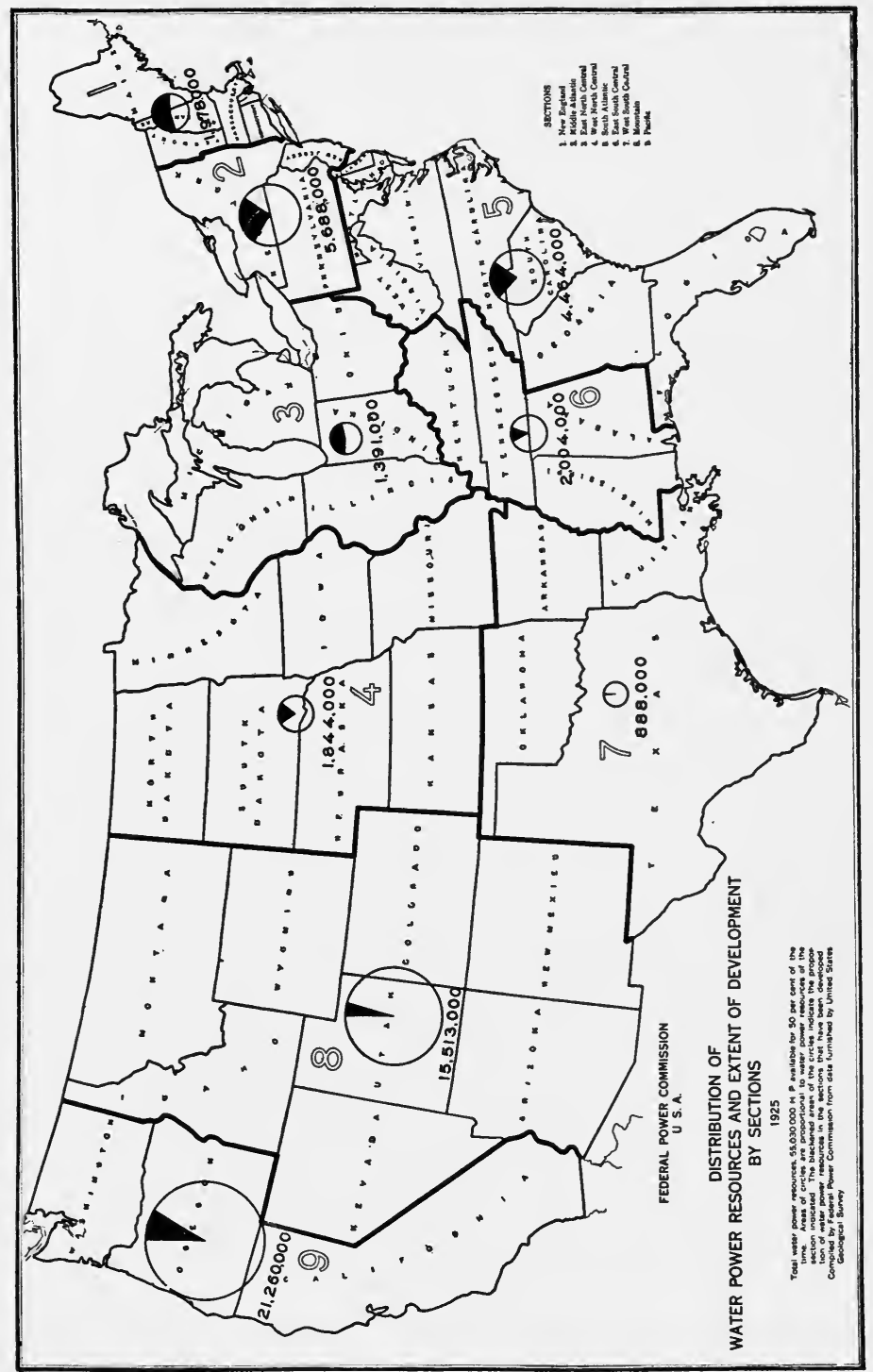




\section{2}

\section{LAND PLANNING IN THE UNITED STATES}

by the American public that the National Parks should be maintained without commercial exploitation of any kind, an amendment to the Federal Power Act was passed definitely exempting the National Parks from the jurisdiction of the Federal Power Commission.

In the utilization of the smaller streams we find in American law a recognition of private ownership of the banks which frequently gives control of the waters for developing power. There are many who regret that in the United States the banks of all streams are not in public ownership for such disposal in the interests of the people as would seem wise. But there are certain limitations placed upon owners of riparian rights which involve the protection of the stream flow and navigation if the stream is navigable.

In any comprehensive catalogue of the natural resources of the United States the power possibilities will bear an important part and the utilization of water power should make a very definite contribution to the standards of living and comfort of the people of this country.

Water for Irrigation.-The rights of cultivators of the soil for water to irrigate their fields, especially in the arid and semi-arid regions of the West, have led to many conflicts in fact and in law. Dr. Ely in the volume on Characteristics and Classification of Land has analyzed the property rights in water for irrigation purposes. We are here mainly concerned with the physical and economic phases of irrigation. Under land uses reference was made to the great reclamation projects, some of which had brought land into profitable use. But attention was directed to those reclamation projects which, while sound from the engineering point of view, had proved unprofitable, and, therefore, unsound from the point of view of the settler who tried to cultivate the irrigated fields and sell his crops for enough to pay the costs on the reclamation scheme and extract a living besides. There is a highly emotional appeal in much of the propaganda for putting water on dry lands and so enabling the desert to blossom like the rose and 
farm families to live in peace and plenty on their homesteads. The promoters of progress and prosperity for the sparsely settled regions, proceeding on a belief that population will bring success to the farmers and merchants alike, have not always informed themselves concerning the economic possibilities of placing water on dry land through the expenditure of enormous sums of money. Here again, inventory, appraisal, classification, and country-wide balance, will lead to the best uses of water for irrigation in any given period.

The location of reservoirs for irrigation involves many more considerations than that of finding a convenient or cheap site for the storage of water. The drawing off of great quantities of water during the dry months lowers the level of the artificial lake or reservoir to such an extent that any use of the banks depending upon scenic qualities is curtailed or debarred. People do not care to build cottages facing on a body of water which becomes a mudhole in the summer months. Likewise the building of reservoirs in the National Parks constitutes a conflicting and adverse use. The question of when and where to place an irrigation reservoir can only be solved by a scientific weighing of values and a determination of the highest use.

\section{SUGGESTED READING}

Richard T. Ely, Mary L. Shine, George S. Wehrwein, Characteristics and Classification of Land, Institute for Research in Land Economics, 1922. Chapter XXII on "Water Rights."

HERBert HOOver, Inland Waterways and Missouri River Navigation, an address delivered before the Missouri River Navigation Conference, Kansas City, October 19, I925.

Public-No. 280, 66th Congress, An Act to create a Federal Power commission; to provide for the improvement of navigation; the development of water power; the use of the public lands in relation thereto, etc.

Federal Power Commission, Developed and Potential Power in the

United States, mimeographed statement, August 21, 1925.

Elwood MEAD, Irrigation Institutions, Macmillan, 1903. 


\section{LAND COMMUNICATION}

It is a far cry from the dirt roads or paths of the 17 th century which served the Colonies to the project undertaken by Congress at the beginning of the rath century for a $\mathrm{Na}$ tional Highway which should connect the Atlantic with the distant Mississippi River. The newly-established Republic of the United States of America had inherited most rudimentary routes of travel. The settlements were small, the distances great, and the fertile lowlands of the coastal plain did not, in their natural condition, furnish a solid substructure which could withstand the heavy summer rains and the devastating thaws of snow and ice. In the early part of the I8th century mail from Boston to Williamsburg was delivered every four weeks in summer and every eight weeks in winter. In I790 there were only seventy-five post offices in the United States. It was not until after the Revolutionary war that the first wagons crossed the Alleghenies. Because the conditions of travel were so intolerable, private enterprise undertook the burden of providing roads through the construction of toll pikes. By 1828 nearly 2380 miles of toll roads were constructed in Pennsylvania alone, at a cost exceeding eight millions of dollars. As an investment these ventures proved failures more often than not and certainly they did not promote through travel for the toll road system resulted in the operation of roads in comparatively short units.

The Old National Road.-In 1806 Congress authorized the building of the great highway to connect the Atlantic with the Mississippi. It was to begin at Cumberland, Maryland, on the Potomac, to which point there were already good toll 
roads in existence, and to traverse the mountains of Maryland and Pennsylvania and the hills and plains of Ohio and Indiana, to cross the Wabash and finally reach the Mississippi. "For thirty-two years the government struggled with this great enterprise," recounts Mr. L. W. Page, "until finally the appropriations ceased altogether in 1838 and the work was discontinued after an expenditure of $\$ 6,824,919.33$ appropriated by Congress." Between I8Ir and I845, Louisiana, Indiana, Mississippi, Illinois, Missouri and Iowa were aided by Congress through revenues turned over from the sale of public lands to the extent of about $\$ 5,000,000$. "Between I854 and the beginning of the Civil war Congress appropriated something like $\$ I, 600,000$ which was expended chiefly on roads within the territories. Thus, up to $186 \mathrm{I}$, the National Government had assisted in road building throughout the United States to the extent of about fourteen million dollars."

Transcontinental Trip in 1859.- Then came the railways and the long-distance highways were forgotten. Roads became local except for occasional and difficult use by the cumbersome and slow four-and-six-horse-drawn wagons. In 1859 Horace Greeley made an overland journey from New York to San Francisco. Illinois, he remarked, was just beginning to be cultivated. He did not predict much success in securing permanent settlers. He traveled by train to Quincy, by boat to Hannibal, Mo., by train to St. Joseph and by Missouri River steamer forty miles to Atchison and from there by two-horse wagon eighty miles to Osawatomie. Twelve miles south of Atchison they struck the Great California Trail from Leavenworth west. Greeley noted that

"The Great California Trail, like the Santa Fé and all other primitive roads through this territory, commonly keeps along the highest divides or prairie swells avoiding the miry 'bottoms' of the streams and (so far as possible) the ravines which the water falling on the high prairie has cut down, although of course winding considerably but making the best and most serviceable and natural road that can be and one that in dry weather is excellent and in wet 
weather as good as possible. But each settler along this trail, in the absence of any legal establishment of the trail as a highway, is at liberty to run his fences right across it as the line of his land runs, and so crowd it off the high 'divides' into all manner of angles and zigzags, across this ravine and into that slough, until the trail is fast becoming the very worst road in all Kansas. I have had a pretty full experience of bad roads during this week; but the very worst and miriest was that portion of the California Trail (the U.S. military road from Ft. Leavenworth west to other forts) which works its sinuous way through the region generally settled by thrifty farmers, lying directly west of Leavenworth."

Greeley bore testimony to the extended use of this transcontinental highway and the method of travel:

"As we neared the California Trail the white coverings of the many immigrant and transport wagons dotted the landscape, giving the trail the appearance of a river running through great meadows with many ships sailing on its bosom."

Greeley mentioned crossing the Santa Fe Trail at right angles near the village of Olathe.

We are accustomed to assume vast expenditures of money for rolling stock on a railway, but probably few of us realize the extent of the equipment and investment of the private companies which carried passengers and freight over the relays of the California Trail to the frontier settlements. Speaking of a single transportation company Greeley exclaimed:

"Such acres of wagons! Such pyramids of extra axle trees! Such herds of oxen! Such regiments of drivers and their employees! No one who does not see can realize how vast a business this is nor how enormous are its outlays as well as its income. I presume this great firm has at this hour two millions of dollars invested. ... (They must employ 6000 teamsters and work $45, \infty 00$ oxen)."

After a lapse of more than half a century the automobile brought new long-distance uses and stimulated transcontinental highways running in all directions.

Federal Aid Roads. - Through the Federal Aid Road laws of 1916 and since, routes of national importance have been 
selected by linking up existing highways, by straightening and grading where desirable, and, most important of all, by furnishing each year an increasing mileage of hard surface.

Lincoln Highway Association.-The Lincoln Highway Association was organized in 1913, three years before the passage of the Federal Aid law. In that year an enterprising American by the name of Carl G. Fisher organized a tour of Indiana automobile manufacturers from Indianapolis to the Pacific Coast. There was a compelling urge in the idea of "scouting" a "main line back-bone of an American highway system," and the Lincoln Highway Association undertook the work of "selecting, promoting, and gaining co-operation in the construction of 'a road first' across the continent."

In 1913 it is estimated that less than I 50 motor cars had crossed the continent under their own power. By 1923, ro years later, it is believed that 25,000 cars, carrying perhaps 100,000 people, had crossed on the Lincoln Highway alone. During those ten years the Lincoln Highway Association had raised and expended over a million dollars, about one-third of it in actual construction.

In the early days of the Lincoln Highway there was the same struggle between localities to make sure that the road would come their way that existed in the early days of railway building. Considering the topography, however, the Lincoln Highway to-day traces a fairly direct route across the continent from New York to San Francisco. As the transcontinental travel becomes heavier and the determination of the tourist to make the shortest connections becomes more insistent a few of the remaining kinks in the road may be ironed out, or, at least the building of more direct local connections will divert a large part of the through travel to the shortest possible route.

It was at first the desire of merchants in the towns that the transcontinental highway should be so routed that it would pass through the principal business streets. In many cases the Lincoln Highway markers are yet to be found 
carefully placed on the congested, and sometimes narrow, business streets of the towns and cities along the way. But there is coming to be an increasing demand on the part of motorists and perhaps a dawning acquiescence on the part of merchants that through travel be by-passed around the congested sections of the towns. Such routing will allow ample opportunity for tourists to make purchases, as they can easily reach the business districts, but it will avoid clogging the available traffic and parking spaces which are needed by those who have business to transact. The business men who visualized the advertisement of their wares and their town to the passing motorists never dreamed that for months during the year there would be a practically continuous procession wending its way through the commercial streets of the town.

The Lincoln Highway has, perhaps, had more advertising than any of the modern transcontinental routes and the idea which made it possible led to the revival of interest in the Old National Highway. We now have the National Old Trails route which runs from New York and Washington through Cumberland and follows closely the national pike authorized by Congress over a hundred years ago. The route from Cumberland is roughly the route which Braddock took through the wilderness. From Wheeling the Old Trails route passes through two State capitals, Columbus and Indianapolis and then on to St. Louis, across the State of Missouri to Kansas City, and then by way of the Old Santa Fe Trail to the ancient and picturesque plaza of Old Santa $\mathrm{Fe}$ on the high plateau of the Southwestern Rocky Mountains. From Santa Fe the road proceeds across the semi-arid regions of New Mexico and Arizona, running a little south of the Grand Canyon, across the Mohave Desert, over the Cajon Pass and through the citrus orchards of California to the miracle city of Los Angeles, a distance of $328 \mathrm{I}$ miles.

Other Highway Associations.-Numerous other transcontinental highways are now designated and in a more or less improved state of development. The Theodore Roosevelt 
International Highway from Portland, Maine, to Portland, Oregon, includes along its route Niagara Falls, a strip of Canada, the Michigan peninsula, Duluth, Glacier National Park, Spokane and Seattle. There is the Yellowstone Trail from New York and Boston by way of Cleveland, Chicago, Milwaukee, Minneapolis, Yellowstone National Park, Butte, Spokane and Seattle. There is the Roosevelt National Highway or the Midland Trail which starts at Washington, D. C., runs through the Valley of Virginia into Kentucky and by way of Vincennes, St. Louis, Kansas City, Topeka, Denver, Grand Junction and Salt Lake finally reaches California with a branch to San Francisco and one to Los Angeles. Another main route across the continent from New York to San Francisco is the Pikes Peak Ocean to Ocean Highway, or the Pershing Transport route, which touches six State capitals (Harrisburg, Columbus, Indianapolis, Springfield, Salt Lake. City and Sacramento) and just misses three others (Jefferson City, Denver and Carson City). More recently the Lee Highway has come into existence leading from Washington through the Valley of Virginia by way of Knoxville, Chattanooga, Memphis, Little Rock, Dallas, El Paso, Phœnix and Yuma to San Diego. It is probable that this route may come into larger use as a winter road to California, since most of the more northerly passages are blocked by snow in the mountain passes during many months of the year. The Old Spanish Trail, leading from Jacksonville, Florida, through New Orleans, Houston and San Antonio, joins the Lee Highway east of El Paso and is identical with it further west.

The north and south highways are becoming equally well known and traveled. The Atlantic Highway from Calais, Maine, connects the principal cities of the Atlantic seaboardBoston, Providence, New York, Philadelphia, Baltimore, Washington, Richmond, Raleigh, Columbia and Savannah-with Palm Beach and Miami, Florida, a distance of some 2300 miles. The Dixie Highway with its various alternate routes crosses the continent from the Great Lakes to Florida. The 
Jefferson Highway runs from Winnipeg, Canada, by way of Minneapolis, Des Moines, Kansas City, Joplin, Muskogee and Shreveport to New Orleans, 2277 miles. The King of Trails runs from Winnipeg by way of Fargo, Sioux City, Omaha, Kansas City, Muskogee, Dallas, Austin and San Antonio to Laredo on the Mexican border, I99I miles. Partly coincident with this is the Meridian Highway leading also from Winnipeg by way of Fargo, Wichita, Enid, and Fort Worth to Galveston, 1908 miles. The Pacific Highway from Vancouver, B. C., by way of Seattle, Portland, Sacramento, San Francisco, Santa Barbara, Los Angeles and San Diego to Tia Juana, Mexico, has a length of 1807 miles and is more highly improved than the Atlantic Highway.

There are numerous inter-State highway routes, many of them following old pioneer trails. There is the Oregon Trail highway from Seattle by way of Walla Walla and Boise to Salt Lake. There is the Arrowhead Trail leading from Salt Lake to Los Angeles.

The Highways Green Book for 1922 lists twenty-four transcontinental highway organizations and twenty-two inter-State highway organizations. These forty-six highway associations have adopted colors and emblems which can be recognized readily. The red, white and blue bands of the Lincoln Highway may be distinguished by the addition of the letter " $L$ " on white from the red, white and blue stripes of the National Old Trails road. The Roosevelt National Highway or the Midland Trail, is marked with orange, black and orange bands and so on down the list. The sections of the national highways are frequently coincident with numbered or named State highways, but there is a distinct advantage in the national markings for the through travelers. These national highways which bind the east with the west and the north with the south are highly significant in national planning and, if they do not come to grief through catering to the conflicting claims of communities along the way, they are destined to exercise a powerful influence in promoting national unity. 
American Automobile Association.-The organization of these separate associations to aid in routing, marking and improving co-ordinated transcontinental and inter-State roads was antedated some years by the formation of the American Automobile Association in 1902. The Highway Associations have been definitely stimulated by the American Automobile Association, but the influence which the Association has exercised on Federal and State legislation has constituted a far more important service to the people of the United States. Indeed the improvement of highways could hardly have proceeded at a satisfactory rate without the Federal legislation which followed the demand crystallized by the A.A.A.

In I 908 at the Buffalo convention there was held the first National Road conference. In I9I2 the Association held the first Federal Aid Convention in Washington, D. C. It was at the instance of this meeting that the joint committee of the Senate and House of Representatives was formed to investigate and report upon the subject of Federal Aid to Highways. In I 1912 there was an appropriation of $\$ 500,000$ for improvement of selected post roads under the direction of the Secretary of Agriculture and the Postmaster-General "for the purpose of ascertaining the saving in rural delivery operation," as a result of road improvement. States and other subdivisions were required to provide local funds in order to secure the benefits of the act. In I9I3 the Committee on Roads was established in the United States House of Representatives. In I9I4 the formation of the American Association of State Highway Officials was effected at Atlanta.

Bureau of Public Roads.-As early as 1893 the United States Government set up an Office of Road Inquiry. When the Federal Aid Act of I 916 was passed by Congress, 23 years later, it was this office which was developed into the Bureau of Public Roads in the Department of Agriculture. This law of I9I6 stimulated, and the law of 1921 insured, the organization of responsible State Highway Commissions in charge of State highway systems. During the fiscal year of $1923-4$ 
the "final designation and approval of the Federal-aid highway system in all the States of the Union" was an important contribution to National, as well as State, planning. A map published in November of 1923 , "presents a definite plan for the improvement of the main highways of the Nation-a plan which it is possible to carry out in a period of not more than ten years." This arterial highway system will be supplemented by connecting roads and feeders giving access to all populated parts of the United States.

State Highway Systems.-The official State highway systems now aggregate $2,866,06 \mathrm{I}$ miles. Seven per cent of these, or 200,624 miles, may be included in the Federal-aid highways system. Under the I92 I law Federal aid is now being directly applied to a limited section of inter-State and inter-county roads, selected by co-operation of the Secretary of Agriculture and the State Highway Departments. It is declared by the Bureau of Public Roads that "this system will serve directly nearly every city of 5,000 population or greater and, with the secondary and local roads which will be connected with it, will carry the increasing highway traffic of the United States with a minimum of inconvenience and delay. The Federal-aid system itself will penetrate within ten miles of the home of 90 per cent of the people. The system as at present approved includes 178,797 miles."

Up to June $30,1925,46,485$ miles of Federal-aid roads had been built since the passage of the first Federal-aid road act.

The Bureau of Public Roads has rendered a notable contribution to the cause of National Planning in the routing of State highways, which, joined together, form National highways. In the Pacific Coast and Mountain States, according to the Bureau, "attention has been given especially to the acceleration of the improvement of through roads to the coast, particularly in Nevada and Utah toward San Francisco. In these States the national need for through east-and-west connection does not in all cases coincide with the highway needs of the locality. This is a situation which is peculiar to the 
sparsely-settled Western States. Elsewhere it is found that the national and local needs are practically identical."

So far from the Public Roads Bureau and Federal Aid having relieved the States of road responsibilities, it has greatly stimulated the States. The implicit faith in local self-government led during the Colonial and National periods to a distribution of authority and responsibility which has seriously hampered the development of State-wide policies concerning the physical layout in the States. The States were jealous enough of their power and authority as against the United States, but only too often State governments have subdivided that responsibility and farmed it out to lesser governmental units. In the States which are divided into counties authority was passed on to the counties. In many instances the counties subdivided this authority and farmed it out to the townships or to specially-created districts within the country.

There may be some advantages in this exaggerated form of placing responsibility in small local units but the physical layout of land suffers from the totally unrelated and independent action of a large number of authorities each controlling small areas. Under the influence of the Federal-aid laws, nearly every State has now designated a State Highway system for which it is responsible both as to route and upkeep. Through the State Highway Commissions, the principles of Planning are beginning to be applied. In many States the main trunk line system of roads connects the State Capital with other important centers and also connects the county seats with the Capital and with each other. In Ohio certain "main market roads," are designated. In Pennsylvania, the State Highway Department, in planning the State system, "ignored the factor of assessed valuation and county lines, and designated a trunk line system, connecting the centers of consumption with the centers of supply."

The development of State Highway systems during the last ten years has been little short of marvelous, and the application of planning principles to the State systems is certain to 


\section{LAND PLANNING IN THE UNITED STATES}

exercise a very potent influence on county and local roads. Not only has road building proceeded with unprecedented activity, but the wholesale rerouting of old roads has brought about more direct communication over better grades for many thousand miles of public highways.

Arrangement of State Highways.-The arrangement of National and State highways has not generally proceeded much beyond the provision for drainage, pavement or surfacing, and the installation of safety and direction signs. In some States a horse-and-wagon road is provided in addition to the paved strip for motor vehicles. This is usually a single-way dirt or gravel road on one side of the hard-surfaced space. Seldom is there a pathway for pedestrians. In the alluvial soils of the Mississippi Valley there are many State highways where the gravel surface is pressed into a high crown which slopes sharply into deep ditches on either side of the road. No attempt is made to render the roadside attractive or pleasing to the eye. There are few young trees along the National and State highways. Only too frequently the sturdy old trees which were obviously planted by the owners of property facing the highway have been cut into grotesque shapes to give room for telegraph and telephone wires. Indeed the ordinary highway, even when it is well paved, has little to recommend it to the pleasure driver.

There are, of course, notable exceptions. In the scenic areas there are many winding highways which thread their way between natural forests and so have a heritage of roadside trees. There are river roads which follow the banks of picturesque streams. But little advantage has been taken of the opportunities for interesting development of the roadside space through a better arrangement of shade trees, provision for wires, paths for pedestrians, and frequent parking areas for standing vehicles.

Progress in marking roads has made better headway. Most States set up markers for the State system. Some States use numbers, others names and still others both names and 
numbers. Occasionally symbols are used. Frequently the telephone poles are painted with colors arranged in recognized bandings. Some of the metal and wood markers carry also the mileage from points of destination. There are caution signs for cross roads, for grade crossings and other possible dangers. In the mountain roads and in the hilly country most of the highways are marked with danger signs for curves and heavy grades. Over the summits of hills a center line is painted or cemented into the pavement to remind drivers to keep to the right.

These markings are much more effective when they are not mixed with advertisements. Many States now prohibit advertising signs within the right of way of the highways. If billboards exist in these States they must be placed on private property. The restriction of billboards generally extends to prohibition at intersections where the vision of clearance is blocked. In many scenic areas billboards are altogether prohibited.

Motor Traffic.-The importance of the routing of National and State highways can only be measured when the volume of passenger and freight traffic which they accommodate is considered. In 1925 there was a motor truck for every fifty people in the United States. While there are many long hauls, the greatest use of motor trucks is for the moderate and short haul which is exactly the least profitable and most tedious service which the railways render. The motor traffic, like the water traffic, should supplement rail transportation. The three can be so co-ordinated that the American people shall receive a service unequaled in efficiency, speed and cheapness. But the routing of the three methods of transportation should be planned with reference to each other and not separately. And the carriers offered should bear a reasonable relation to the transportation needs of the country as a whole rather than to the special claims of specific places.

The growth of motor passenger service is amazing. On the Pacific Coast one may travel in large comfortable automobiles 
from San Diego to Seattle or any lap of the trip. Though the time consumed is naturally greater than by train the scenic routes of the highways and the open-air travel attract a large patronage. A limited motor service runs west from the Atlantic seaboard; but though the trip across the Alleghenies is scenic the flat country of the Mississippi Valley is less interesting and the distances result in a time consumption that has worked in favor of rail travel for the majority of travelers. Of course the private cars will continue to use the long, as well as the short, routes for pleasure travel. As for the rural and town salesman, he and his automobile have become standard equipment.

Railways.-The miles of steel rails which mark an intricate pattern on the face of the map of the United States were first laid by many different companies. The close network of lines in the Eastern States and the more open mesh of the Western region were the result of routes selected by competing companies.

In $186 \mathrm{I}$ when the railways of the country were little more than thirty years old, the Lewis Railway Directory showed that there were already nearly 32,000 miles of railways. It may be remembered that it was in 1859 when Horace Greeley made the trip across the continent which he recorded in his diary. In $\mathrm{I} 86 \mathrm{I}$ the pony express still linked the Missouri River with California. These 32,000 miles of railway were owned by not less than 335 separate companies. The "systems" of those days averaged one hundred miles in length. The New York Central was the most-used line in the United States with its 654 miles. The Baltimore \& Ohio, first in the field, had $5^{1} 8$ miles and the Pennsylvania 380 . The Illinois Central had a trackage of 706 miles which was in excess of that of the New York Central but the traffic was not to be compared. In I86I the Erie had 563 miles of track and the Chicago and Northwestern 193.

There came a period of consolidation attended by many abuses which led to various State laws and finally to the Sher- 
man Anti-trust laws with their influence toward decentralization of control and operation. But the great war showed clearly the waste of too small railway units with terminal points which necessitated trans-shipment. The routing of freight cars and the provision for their economic utilization made imperative some sort of consolidation of interest which would eliminate waste in handling loaded and empty cars in long hauls.

To-day we have in the United States in excess of 250,000 miles of railways and this constitutes about $45 \%$ of all the rail mileage in the world. Eighty-five per cent of the business handled by the railways is now done by twenty-two roads. Of the 55,000 miles in the Eastern States, the Pennsylvania has about 12,000 , the Baltimore and Ohio 9,000 or 10,000 , the Erie 16,000, and the New York and Michigan Central 12,000.

The building of the early railways in the Eastern States required vision, initiative and enterprise; but the building of the Union Pacific Railroad through the muddy plains of the Missouri, across the Rocky Mountains, over the sandy deserts, across the lofty Sierras to California was a stupendous undertaking. Federal aid in the form of franchises and land grants did not prevent financial difficulties during the period of construction and early operation. The $196,569,372$ acres of land granted by the United States Government to the builders of railways was not at the moment an asset which could be quickly converted into cash. What the railways wanted was settlers who would bring patronage to the lines, not empty acres of land. What the Government wanted was settlers who would in time pay taxes. From the point of view of National Planning the routing of the first transcontinental railway connection was an important contribution to the development of the country, and remains one of the principal rail routes to-day.

We now have at least two important through northern rail connections to the Pacific Coast, one central and two southern lines. The continent can be crossed in comfort in less than five days and nights; though on many lines it is necessary to 
change trains and frequently not even Pullman cars are switched from one road to another. If all roads led to Rome we may say that all railways terminate in Chicago. Occasionally several roads have combined to operate a single terminal station; but the passenger is fortunate who is not obliged to drive from one station to another in an effort to pass through Chicago. Many far-seeing railway officials have advocated the abolition of metropolitan terminal stations which bring into the center of the city an enormous traffic only to route it immediately out again. Railway traffic might be by-passed quite as effectively as we are now trying to by-pass through automobile traffic.

Professor William Z. Ripley has called attention to the need for re-routing the main traffic arteries between New York, Philadelphia, Chicago and Saint Louis. Particularly is there need for an air-line route from New York to Chicago. The New York Central by way of the Mohawk Valley necessitates a long trip directly north before the westward turn may be made. The Erie makes a less apparent northward bend, but pursues a winding route which adds to its mileage and traverses a country with few cities and towns, a fact which has added to its economic difficulties in the past. The Pennsylvania and the Baltimore \& Ohio both bend far to the south. The causes for these round-about routes, declares Professor Ripley, are both geographical and political. The layout is wasteful for present-day practice. Each of the Big Four Eastern railway systems desires to secure existing short links which, with additional mileage, would shorten the long haul for an already overcongested freight traffic.

It was this complicated situation that led to the passage of the Transportation act of 1920 directing the Interstate Commerce Commission to prepare a tentative plan for the consolidation of the railways of the United States into a limited number of systems. On the basis of this, after discussion and hearings, the Commission was directed to formulate a second plan, based on the evidence. "All these great questions 
of national importance deserve consideration in the biggest possible way. How can they be so considered except by some planning ahead?" inquires Professor Ripley. Have we not arrived at the place where routes may be chosen in the interest of the public as a whole? May not railways depend for their profit on economic routes over which great volumes of traffic normally will flow, without being obliged to snatch special monopolistic advantages which they can squeeze out of competitive enterprise? Certainly the general public would welcome a 900-mile railway between New York and Chicago. There seems to be good reason to believe that there is now room for five main east-and-west systems between Chicago and the Atlantic seaboard. Let us hope that the Interstate Commerce Commission will be equal to the task of preparing a regional railway plan of national significance.

Telegraph and Telephone Wires.-In 1852 there were in the United States 16,735 miles of pole line and 23,28I miles of single wire stretched across the face of the land by the commercial and railway land telegraph systems. In 1922 there were 252 ,99I miles of pole line and I,849,3 I 2 miles of single wire. The pole lines alone would reach around the world at the equator more than ten times. The extent of the service to the people of the country may be measured by the $185,841,267$ messages reported in 1922 . The commercial, political and human value to the Nation of the telegraph systems is difficult to calculate. Whether the increasing use of wireless communication will eliminate or curtail the wire service is impossible to predict. At present the plant and equipment of the land telegraph systems in the United States aggregate over $\$ 250,000,000$ in value.

The mileage of the telephone wires is even more astonishing. There were in 1922 in the United States $37,265,958$ miles of telephone wire over which were sent $24,647,560,860$ calls. There are now nearly 15,000,000 telephones in the country, or one telephone for about every 7 persons, including men, women and children. In 1902 there were $4,900,451$ miles of 
telephone wire of which $1,700,042$ were underground and $3,200,409$ were overhead. In 1922, of the $37,265,958$ miles, $2 \mathrm{I}, 440,47 \mathrm{I}$ were underground and I5,825,487 were overhead. Every year more wires go out of sight. The future will disclose methods of carrying wires above the surface in less objectionable ways than at present for those stretches of territory where the cost of underground installation is prohibitive.

Telephone communication has assumed a national significance. How far radio will affect it remains to be seen. Longdistance planning cannot penetrate the scientific discoveries of the future.

\section{SUGGESTED READING}

L. W. PaGe, Roads and Bridges, New York, 1912.

Horace Greeley, An Overland Journey from New York to San Francisco in the Summer of 1859 , New York, I860.

ERNeSt N. SMith, "Men Who Made the Lincoln Highway," in American Motorist, September, 1924.

American Automobrle Association, A National Highway System, a pamphlet.

Department of Agriculture, Report of the Chief of the Bureau of Public Roads to the Secretary of Agriculture, October 15, I924. Also, Report of October 15, 1925.

Department of Agriculture, Highways cnd Highway Transportation, Government Printing Office, 1925.

"The Bureau of Public Roads," an Account prepared for Americana Annual, 1925 (March).

Honorable Charles R. Townsend, "The Highway Situation," in The Highways Green Book, 1922, published by the American Automobile Association, Washington, D. C.

Thomas H. MacDonald, "Highway Achievements and Prospects," in The Highways Green Book, 1922.

EDWARD HUnGerford, "Remaking the Railroad Map," in The Saturday Evening Post, March 7, 1925.

Frank A. Waugh, Country Planning issued by the American Civic Association.

Harlean James, "Billboards and the Motorist," in National Municipal Review, July, I924.

William Z. Ripley, "Railroads Strive for 'Air Line' to West," in New York Times, Sunday, March 2I, I926. 


\section{NOTES}

Page 392. The Bureau of Public Roads, besides selecting highways for Federal aid, has been responsible for the elimination of many grade crossings. The Bureau has promoted study of railway and highway intersections with the purpose of classifying them according to the degree of danger existing. The Bureau of Public Roads has co-operated with the Forest Service to build forest roads, particularly with the purpose of making necessary connections on through routes of travel which cross National Forests.

Page 394. Professor Waugh has long advocated the replanning of country roads.

"These roads need replanning. Streets have to be relocated even in the cities and at enormous expense. In the country there has been little or no thought given to the intelligent location of roads for public service. In the Eastern States the roads just happened to be where they are. In the Western States they follow a plan that was wrong. So the whole question is still open. Any man or woman with an intimate knowledge of any 6-mile-square section of country, and with as much imagination as an oyster, knows that he or she can sit down any evening after supper with the map, and, wiping out all the roads as they exist, plan a better layout in half an hour.

"So the location of every mile of country road ought to be challenged, and when it is plain that a better location is possible the change ought to be made. If it cannot be made at once we can wait. Fifty or a hundred years is a small matter with us in reconstructing the country.

"Furthermore, the country roads ought to be classified and different kinds of roads treated differently. There ought to be through trunk traffic lines between important points, all straight and level and well paved. There ought to be also the narrow, crooked country lanes where heavy traffic can never penetrate. There ought to be automobile pleasure roads meandering through the best scenery. There ought to be special scenic roadways along river banks, through cool forests, over picturesque hills where inspiring outlooks abound. These scenic roadways in particular should be planned by the most expert landscape architects, for it is the special purpose of such roadways to emphasize the beauty of the open country to all the world.

"Of course these country roads should all be better built, better administered and kept free from advertising nuisances, from public dumps and all such iniquities. As far as possible, too, the country roads should be relieved of wires and poles and trolley lines. None of these things has any real right on the public property anyway."

Page 395. Is the dislike of motorists for the billboard well based? The question is answered by the author.

"Why do motorists dislike billboards? In the first place, as has been indicated, the pleasure motorist is looking for beautiful scenery 


\section{LAND PLANNING IN THE UNITED STATES}

which ${ }_{4}$ in spite of ax, hammer and billboards, still exists in considerable areas in the United States. Now, whatever may be said for what is recommended as an 'artistic' billboard placed on a vacant lot between two commercial buildings in a dingy little town or a sprawling, ugly city at the awkward age, there is little to be said for painted boards placed in the foreground of magnificent water falls, stupendous mountain cliffs, or even of pleasant pastures and treestrewn hills. . . .

"It is fair to ask whether the "bottom has not fallen out of the outdoor advertising business' in scenic locations. The signs along highways are placed there to secure the patronage of motorists. If motorists become annoyed because of the insistence of the advertisers, the value of the location has disappeared, for, surely, no manufacturer would be so foolish as to spend money in order to alienate purchasers from his commodity to that of his competitor."

Page 395. The Chief of the Bureau of Public Roads has commented on the freight traffic of the highways:

"With the rapid growth of highway transportation the history of the development of rail transportation has been repeated; conflict, misunderstanding, and duplication of service between the old and new facilities have developed. The utilization of the motor truck for the transportation of freight is a development so recent that its proper sphere as a part of our complete transportation system is still to be established. Recent tendencies in its growth have indicated that its proper field of operation is not in the long-distance movement of commodities, but in a service supplementary to rail and water lines and in the movement of goods within the terminal and short-haul zones. Rail and boat lines are testing the practicability of combined service by the utilization of the motor truck for the movement of freight in the short-haul and congested terminal areas. Its success appears to demonstrate an increased use of the motor truck in this particular field."

The Bureau has promoted traffic surveys which should exercise an important influence upon the planning of highways. A field study of the influence of highway improvement on rural land values in I6 counties in Iowa makes available conclusions which determine "the limits of increase in rural land values iesulting from the several types of highway improvements" and assist "in determining the amount which rural land can economically contribute to highway improvements on the basis of increased values per acre resulting from the highway improvement." 


\section{THE GREAT AGRICULTURAL LANDS}

Lack of Plan in Growing Crops.-The agricultural land of the United States is, with negligible exceptions, in private ownership. Much of it is devoted to "general diversified farming." A regular rotation of crops is put in regardless of the over-production or under-production resulting from the unsupervised action of thousands of other farmers. A man's house may be his castle and a man's farm may be his estate on which he may do exactly as he pleases. There are definite limitations which farmers must observe. Cotton is not a New England crop. Corn does not do well where the growing season is too short or the soil too light. But ordinarily, there is a wide range of crops which can be produced on a given farm. The decision concerning what to plant each year depends, not only on local markets and shipping conditions, but on national, and sometimes even international, production. The Department of Agriculture, with its network of research bureaus and its co-operation with States in an extension service, places at the disposal of the farmers of the country exceedingly valuable information and even more valuable guidance. But the Department of Agriculture has nothing to say about route of railway connections and freight and express carriage of crops, nor can it control railway rates.

Marketing.-The importance of marketing is shown by the attention given to it by the Bureau of Agricultural Economics. The organization of the California fruit growers has demonstrated what enterprise can do in the marketing of crops in Eastern markets even when they are grown three thousand miles away. Along the Atlantic seaboard fresh vegetables 


\section{LAND PLANNING IN THE UNITED STATES}

from California and Florida are now consumed throughout the winter months.

The systems of circulation and communication,-rail, water, motor, and other,-are in reality a part of the farm plant, for the great acreage of farm land cannot depend on home consumption of the crops grown. There is every reason to suppose that planning on a national scale would render a service to producers and consumers alike. It is believed that there is a great deal of unnecessary shipping at present. Goods are hauled and cross-hauled back again. The railways are not dependent, now, on securing every bit of business they can capture, whether the national economy is served or not. The waste in unnecessary transport can only be located and eliminated by careful surveys of the facts and even more careful analyses of the economic markets for each product from each region. This does not involve regulation. It does involve the distribution of reliable information which would, in all probability, control the great bulk of production and marketing because of its economy.

But farmers suffer even more from the possession of land which it is unprofitable to cultivate in the conventional crops even under fairly favorable marketing arrangements. Here again, the State Experiment Stations under the leadership of the Department of Agriculture have rendered valuable service; but we are far from a time when the size of farms is adjusted to the value of the crops which they will produce. The abandoned farms in the once-forested regions of the East and Middle West bear silent testimony to the fact that great areas of submarginal land have been mistakenly brought into crop cultivation. The Michigan Economic Survey was promoted primarily because of the great unused areas which had been abandoned, some to revert to State ownership because of nonpayment of taxes, others to lie idle in non-resident ownership.

Land Surveys.- - If every State in the Union were to undertake during the next decade to conduct a Survey similar to that of Michigan, no doubt many pertinent facts, now entirely 
unsuspected or only dimly perceived, would be brought to light. At any rate we can hardly expect to put land to the best use if we have made no inventory of its qualities and no classification of its possible uses. The fact that the farms of the country are owned or operated by private individuals or corporations not united in partnership does not in the least indicate that the need for an inventory is not pressing.

Many remedies have been proposed to mitigate the hard lot of the farmers during the past seven years of deflation. They have suffered without any compensating benefit to the consumers. A National survey and classification of farm lands and a National plan for economic transport, worked out by regions, would not cure evils brought about by other causes; but it would lead to more economic adjustments.

Acres in Crops.-In 1924 it was estimated by the Secretary of Agriculture that about 370,000,000 acres were in crops in the United States. From I9I9 to 1923-4 the value of farm land and buildings decreased from $\$ 66,316,000,000$ to $\$ 48,300,000,000$. The gross income from crops, less feed and seed, declined from $\$ 15,830,000,000$ in $1919-20$ to $\$ 11,467$,000,000 in 1923-24. Even at the marked-down valuation, there is a fairly large investment of capital and a combined income of no mean proportions.

Two outstanding results from economic surveys of lands might be expected. Agricultural lands might be cropped to better advantage. Land unsuited to the growing of crops would be eliminated. Some of this discarded land would be planted to forests or allowed to reforest by natural volunteer growth. Other land, even in the Eastern and Middle States, might be found useful for grazing. The tide of population, sweeping across the country, has left great open spaces not now used. We cannot conceive of the entire East as closely populated. The State of New York not only has its vast forest and park reservations, it also includes 190,000 farms. Indeed, of the thirty-odd million acres in the State, twentyodd are in farms, about one-fifth of which is in woodland. 
Ranches and Grazing.-Of course the era of "free grazing" has passed forever from the States of the Eastern part of the United States. If grazing lands are established they will be either in private ownership or, if in State ownership, rented for an economic income. It is in the Western States where we have the wide ranges and the sizable ranches. In the arid regions even with stock there are many sections where a family cannot possibly make a living from 640 acres of land. This is partly due to the drouth which produces a cover so thin that it will not support cattle throughout the year. Even on land where crops can be grown to furnish feed during the winter months it is desirable to provide "summer range" for the stock on the mountain slopes which are inaccessible in winter. On the snow-covered hills sheep can be herded and supported during the winter months if they are moved over the land at a rate rapid enough to provide new forage and snow water as needed.

The controversy between the stock men of the Western States and the United States Forest Service is due in part to the fact that the ownership of a section of land will not make the ranchman independent of outside range. In many cases the United States Government has promoted homesteading and permitted settlers to "take up" ranch land which, in the unit permitted, would not support a family. In this way, many regions in Nevada and elsewhere have in them more ranchers than can possibly find grazing land to make the ranch an economic unit.

It is no kindness to families who have settled on land which cannot be made to yield a sufficient income to allow them to postpone the day when they must move away. Since the Government failed to discover the exact situation before they went on the land, they entered upon a losing fight. But the sort of classification which the United States Forest Service is conducting on the public domain in order to segregate forest land or land capable of forestation should be extended and associated with studies to determine whether 
and how it can be made into units which will support a family.

Colonization Schemes.-In farming, as in residence neighborhoods, it is frequently possible for groups of settlers to create a community which provides social intercourse and makes possible better facilities for farming and better opportunities for marketing produce. Colonization schemes, if based on sound agricultural advice and under the guidance of the Agricultural Experiment stations, may accomplish much that is good; but, too often, land is sold for so-called colonization purposes by those who know nothing of agriculture and, apparently, believe that any land, if it is plowed and cultivated, can be made to yield large and profitable crops.

Sound colonization schemes promise much for American agriculture. They promote farm ownership and operation by those who live upon the farm. They provide a social life which renders farm life endurable and sometimes desirable. Preach as we may, in this day of good roads, good schools, circulating and traveling libraries, organized recreation and public entertainment, the youth of the country, whether we like it or not, do drift to the cities where such facilities may be found. Farm life cannot compete successfully with city life unless the community offers these opportunities, and unless the farms are sufficiently profitable to till that some leisure may be enjoyed.

In closing, attention is called to the fact that land planning is the most important of all the steps that can be taken in solving the problem of the agricultural surplus, by which is meant simply such disproportionate agricultural production that staple crops cannot be disposed of at prices that are profitable even for good farmers who are farming on good land. If land planning in the utilization of land should assign millions of acres of land now being farmed to the production of forest crops, they would help to reduce production of staple crops on poor land and would increase the production of timber, of which there is a great scarcity. We would have a 


\section{LAND PLANNING IN THE UNITED STATES}

far better balance, a far more prosperous agriculture and a far more prosperous country. This cannot be worked out in detail now and here but illustrates the fact that the heart of our agricultural problems is wise planning in land utilization. Let us, therefore, solve our land problem for agricultural and range lands, as the first step in solving our human problem of farm life. We should recognize that for great areas of the country, the farm life problems have been met by just such methods.

\section{SUGGESTED READING}

United States Department of Agriculture, Yearbook, ig20 and years since that date.

Richard T. Ely, Mary L. Shine, George S. Wehrwein, Characteristics and Classification of Land, 1922. Chapters VIII and IX on "Agricultural Lands," and "Range and Ranch Land."

Richard T. Ely and Edward W. Morehouse, Elements of Land Economics, The Macmillan Co., I924. Chapter VII on "Agricultural Land Utilization."

H. C. TAYLOR, Agricultural Economics, Macmillan, 1919, new edition, I925.

L. C. GRAY, Introduction to Agricultural Economics, Macmillan, I924. 


\section{FEDERAL AND STATE PLANNING AGENCIES}

Federal-owned Land.- The Federal Government is an extensive land owner. Certain lands are still held on the theory that they will eventually pass into private ownership. By executive order and legislative authority great areas of the public domain have been reserved from settlement, either temporarily, or for permanent use. Most of the National Forests were taken from the public domain. Many of the National Parks were created from land which was once in the public domain, but set aside from the forest reserves. But lands owned by the War Department and by the Navy Department for various purposes, lands owned for Federal Public Buildings in Washington and in the various States of the Union, the National Forests and the National Parks are held with the expectation of more or less permanent tenure. It so happens, however, that the War Department, the Navy Department and other Federal agencies frequently find that they have no further use for certain lands. Especially since the Great War the various Departments of the Federal Government have placed land on the open market for sale to the highest bidder. This was often done without any thorough-going effort to ascertain whether the land might be needed or used by other Departments.

Legislation in the sixty-ninth Congress has authorized the sale by the War Department of a list of discarded army posts with the avowed purpose of raising money to devote to certain housing needs of the Department, a policy that can hardly be justified from any point of view. The land is owned in fact by the United States Government, but it is under the control 
of the War Department. Until it is pretty thoroughly established that the land will never be needed for public purposes, it should not be sold. The War Department should be permitted to relinquish its custody whenever it is not needed; but a decision of the War Department should not control the sale of land which will alienate it from public ownership. The proceeds from the sale of land should be a capital credit and should not be made available for current expenses or improvements which should be covered by appropriations from Congress without regard to the proceeds from the sale of land. The legislation includes provisions which allow States or municipalities to purchase the land, but the appraisals in some cases have been prohibitive, and the time which it requires for local governments to move on such matters will generally mean that the lands will be sold to private investors.

A much better policy has been that by which, under the Clarke-McNary bill, the War Department has turned over to the Forest Service for custody and use until such time as the areas may be needed for military purposes, abandoned forts and army posts.

Clearing House for Land Owned by the Federal Government.-The need for a responsible Land Board to conserve the interests of the Government as a whole and prevent the sale of land on the decision of the Department no longer needing it, has been recognized by land economists for many years. If there were no direct advantage to a Department by which it could induce Congress to make appropriations by reason of the proceeds of sales of land, that stimulus to sale would be removed. A Land Board might well be authorized to inquire into the uses to which the different departments are putting their lands. With the constant succession of officers in charge, it would not be surprising if adequate inventories of land owned by the various departments were not available.

Federal Agencies Rendering Service for Private Lands.- In addition to the Federal Agencies which administer public lands of various sorts, such as the National Forests, 
the National Parks, the National Monuments, the Army and Navy posts, the light-house properties, and public buildings and grounds, there are a number of bureaus which give information and advice to aid private land owners. The Forest Service gives valuable advice to private owners of forest land. In the case of the great lumber companies the foresters employed by them are often drawn from the public service. The various bureaus of the Department of Agriculture give expert technical advice and the Bureau of Agricultural Economics has inaugurated the various research studies which are leading to better classification of land. The Biological Survey controls Bird and Game Preserves and also gives advice concerning the management of such refuges under other ownership. The Bureau of Mines conducts research studies and gives advice concerning the management of mineral and oil lands. The Geological Survey not only prepares maps but aids in classification of lands. There are numerous other examples; but it will usually be found, that each service conducts its own affairs as though it in fact were the only owner or adviser. This is less true of the group of services within the Department of Agriculture; but it is true most emphatically of the services located across department lines in other divisions of the Government. If a Land Board were created it might add to its effectivenèss if Land Policies could be discussed by the various Federal agents responsible for administering public land or for giving advice to private owners.

State and County Buildings and Grounds.-The selection of sites for State and County institutions has seldom been planned with any thought of co-ordinating such public grounds with other State-owned property. Independent commissions have been appointed to select a location or the question has been decided in the State legislature after a campaign of wirepulling on the part of various localities to secure the political plum. State Highway, State Park and State Forest Commissions are being established; and in a few States these three are being correlated. But no. State has yet realized the full possi- 


\section{I2 LAND PLANNING IN THE UNITED STATES}

bilities of State Planning which shall take into account the State-owned lands and highways together with the State-owned buildings and their relation to the County lands, highways and buildings. Little has been accomplished in planning for the best use of school lands.

Few States have developed land policies, though many have embarked on State Forest and State Park programs which will undoubtedly lead to a more comprehensive planning of State lands.

State Capitals and County Seats.-A recent inquiry sent to officials in the forty-eight capital cities of the States of the Union failed to disclose State participation in any City Plan for these capitals beyond the appropriation of money for acquirement of proper sites for State buildings.

Many States are developing impressive groups of buildings to house State activities. A State Civic Center is being developed in Harrisburg, Pennsylvania, with the famous Capitol as the dominating feature. In the City of Saint Paul adequate approaches are planned to provide a proper perspective to the beautiful State Capitol. The city of Denver has developed an extensive Civic Center in the foreground of the State Capitol. The State of Washington is erecting an ambitious series of buildings. But States have yet to realize their responsibilities for their capital cities beyond the mere public buildings which they erect for their immediate business.

State Action in Planning and Zoning.--In many States a State law or even an amendment to the Constitution is necessary to give to cities and towns the necessary power to enter into full planning control. In most States a law or amendment to the constitution is necessary to give cities and towns power to zone.

In Massachusetts, where nearly $95 \%$ of the population is classed as urban, the State has passed a law requiring every city and town of over ten thousand inhabitants to have a planning board and all smaller places may have such planning boards if they choose. A State Division of Housing and Town 
Planning in the Department of Public Welfare has been set up and this division will supply information and its consultant will meet with boards to help outline programs.

The Massachusetts Federation of Planning Boards was organized in rgr 5 to stimulate planning and to offer an opportunity for discussion of local problems. $U p$ to the end of I924, I6 Bulletins had been issued on various subjects of interest to the cities and towns of Massachusetts. In January of 1924 there were to be found sixty-nine planning boards in Massachusetts. The boards have wide powers of study and recommendation; but the execution of the projects is in the hands of existing administrative officials.

In Pennsylvania there is a Bureau of Municipalities with a Division of City Planning and Municipal Engineering which for a time rendered a valuable service but is hampered for lack of funds.

In Ohio there is an annual State Conference on City Planning, where commissioners, professional consultants and civic leaders may discuss the problems of Ohio cities and those of the State.

These examples will serve to show the trend toward State participation in planning matters. The metropolitan areas and commissions are created ordinarily by special State legislation. We have now one or two State bureaus. There also exist in some States, Land Boards to co-ordinate the land holdings of the States. Sometimes this function is assigned to a General Executive Board or Business Committee.

Whether State Planning Boards or Commissions will be the next step or whether State influence will be exerted through departmental bureaus and divisions remains to be seen. But in some way States are bound to exercise a greater influence on planning than they have in the past. Perhaps the inauguration of Economic Land Surveys will promote consideration on the part of the State of private as well as public lands. Voluntary State Conferences will serve a valuable purpose in co-ordination between the plans of the different localities. State legis- 
latures cannot escape their responsibility for enabling laws and State administrative officials will be forced to informal co-operation, if no official machinery is set up to provide for the proper physical development of the land.

Many of the States have set up Forest Commissions, or other agencies to administer the State forests. New York's first Forest Commission was created in 1885 "to manage and protect the 'forest preserve' which was at that time established from wild lands still owned by the State and aggregating over 7,000,000 acres." New York to-day has nearly two million acres in State Forests. The recreational use of such areas as the Adirondack and Catskill Preserves is becoming yearly more important. The great development of State Forests and State forest policies has come within the last ten or fifteen years. In 1890 the States were spending about $\$ 65,000$ on forestry. In 1922 more than four million dollars was being spent annually by the States of the Union.

The administration of State Parks varies greatly in the different States. Primarily, State Park administration might be said to fall without the field of physical planning, but it has a close relationship. We have pointed out the desirability of planning a State Park system ahead. Many States, such as Connecticut, Illinois, Indiana, Iowa and Michigan, have centralized the responsibility for administering the State parks, either in a Conservation Commission or in a State Department. On the other hand the State Parks and Forest Reservations of New York are administered by entirely separate Commissions, usually appointed by the Governor. A number of State Parks are in the custody of the American Scenic and Historical Preservation Society of New York City. The Adirondack and Catskill Preserves, St. Lawrence, Saratoga Springs, Cuba, Lake George Islands and John Brown's Farm are administered by the State Conservation Commission. Lester Park, Stark's Knob, Clark Reservation, Squaw Island are administered by the State Museum at Albany. Some of the parks are in the custody of patriotic organizations. In all 
there are at least a score of different jurisdictions. In the interests of unified administration one can hardly doubt that some improvements could be brought about. On the other hand the administration of such an intensively-used State Park as the Palisades Interstate Park which is operated by a Commission from New York and from New Jersey especially chosen for that purpose and directly in charge of all of its business affairs might readily suffer if it were thrown into the common pot and administered by a State-wide Commission with headquarters at Albany. The efforts to bring about a centralized State Park administration have so far failed of accomplishment in New York, but a Co-ordinating Board has been organized.

It is conceivable that unified State administration might be advisable in one period of development and not in another. Centralized jurisdiction would almost surely result in the concession system. Those who have watched with interest the service to the people which has resulted from the direct operation of the Commission in the Palisades Interstate Park will be slow to recommend a change.

The need for close co-operation of the Federal and State agencies dealing with land is everywhere apparent. The distinctions of jurisdiction are often arbitrary and have no relation to the characteristics of the land administered. Likewise, the contact and co-operation of the various agencies of government giving advice concerning the use of land is most desirable. Let us keep moving in the same direction.

\section{SUGGESTED READING}

U. S. Department of Commerce, Division of Butlding and Housing, New Edition Standard State Zoning Enabling Act, 1924.

Massachusetts Department of Public Welfare, Division of Housing and Town Planning, Planning Boards and their Work.

Massachusetis Federation of Planning Boards, Bulletin No. I3, January, 1924 .

Pennsylvania Department of Internal Affairs, Bulletin, January I, I92I. 


\section{I 6 LAND PLANNING IN THE UNITED STATES}

J. G. Peters, Development of Forestry in the States, an address delivered at Southern Forestry Congress, Montgomery, Alabama, January 31,1923 . Published in the Proceedings.

Council on National Parks, Forests, and Wild Life, a Policy for National and State Parks, Forests and Game Refuges.

\section{CONCLUSION}

It must be apparent that we are entering on a period of great plans for the future. In preparing to care for a population of two hundred million people we shall need to make the best possible use of our land and its resources. The principles of city planning which we are now applying to our urban communities are equally applicable to rural areas and to regions and States as well as to the Nation as a whole. The application varies with the unit and the need. We must realize the limitations of the local planning unco-ordinated with adjoining areas or with the larger jurisdictions of which the locality is a part. The limitations are not necessarily restrictions. Indeed the small local communities and the large cities are destined to profit quite as much through intelligent State and National Planning as through their own initiative and enterprise.

Already, as a people, we have created a fairly comfortable environment; but this has been done carelessly and because of the existence of the frontier to ease economic pressure. In the future we must plan ahead and make the best possible use of land, both rural and urban, if we are to maintain or improve the comfortable standards of living which we have set up.

We need a Statement of our Land Assets and Liabilities. We need an analysis of our Resources. We need Comprehensive Plans for the best use of our land, both publicly and privately owned. These are not grandiose schemes which it is impossible to formulate. The problem falls into divisions which can be solved by specialists working together. We need less independent action and more team work. 


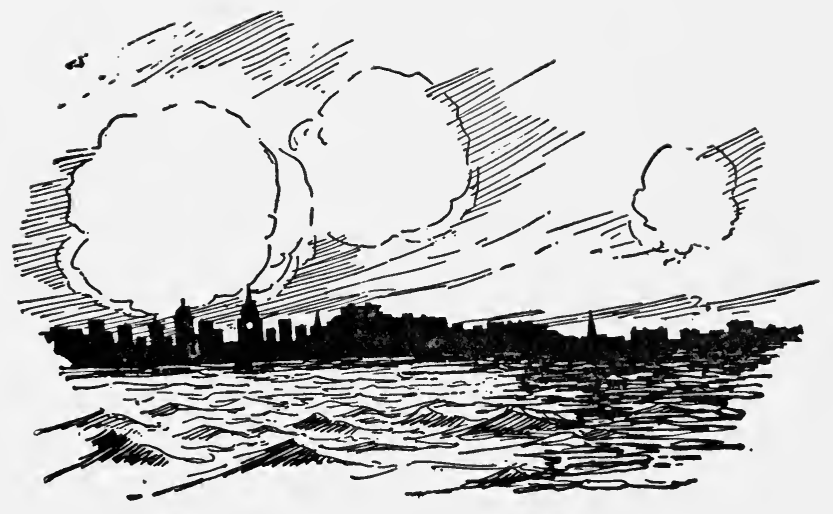

Where land and water meet. San Francisco Harbor. 



\section{INDEX}

Academy of Science, Michigan, 340 Adams, Thomas, 252, 270, 286, $287,289,290,291,295,297$

Agricultural Economics, Bureau of, 329

Airplane landing fields, I92

Albany, early layout, 29

Regional Plan Commission, 284 Alleys and lanes, II3

American Automobile Association, 39r, 400

American City, monthly, 312

American Civic Association, 73, 74, 75, 76, 77, 78, 79, 80, 210, 295, 358,368

American Forestry Association, 345

American Institute of Architects, 54, 68

Journal, 31 2

American Institute of Park Executives, 80

Parks and Recreation, $3 \mathrm{I} 2$

American League for Civic Improvement, 74

American Park and Outdoor Art Association, 74

American Park Society, 80

American Society of Civil Engineers, 58

Proceedings, 312

American Society of Landscape Architects, 54-55

Landscape Architecture, 3I2

Annapolis, early layout, $3 \mathbf{I}$

Architects, co-operation, 47

professional organization, 54

advisory service, Washington, 223

Architecture, World's Fair, 45

Area districts, zoning, 233

Area, increase in United States, ro, 313

Art Commissions, 279

Arterial highways, 99
Assessment districts, 305

Mattoon Act, 3 Io

Assessments, special, 302

Automobiles and suburbs, I53

congestion, 138

regulation, I40

segregation, I42

traffic on State and National highways, 395

Babcock, Frederick M., 340

Ball, Charles B., 58

Baltimore, Roland Park, 34, 223, 262

arterial highways, Ior

Druid Hill Park, II 7

Municipal Art Commission, 280

Bangor, Maine, Manning report, I08

Barber, A. B., 155

Bartholomew, Harland, 8I, I52, $155,157,295,309$

Bassett, Edward M., 81, 94, 239, 240, 24I, 248

Bennett, E. H., $7 \mathrm{I}$

Bibbins, J. Rowland, I40, I58, I7I, I 72

Billboards, 395, 401, 402 and zoning, 244

Binghamton N. Y., Robinson report, 70

Black, Archibald, 192, 193

Black, Russell V., 42

Blighted districts, 235

Blocks, interior use, II4 and lots, 213

Boards of Appeal, zoning, 279

Bonner, Capt. John, 42

Boulevards and pleasure roads, II 7

Boundaries, permanence of, 3 of early grants, 16

Boston, early layout, 32

region, 249

Division of Metropolitan Planning, 283 
Bouton, Edward H., Iro, I18, I25, 263

Brown, Edwin H., 82

Bruce, P. A., 23

Brunner, Arnold, 42, 72, 228, 229

Bryce, Viscount James, 8I, 268

Buffalo, regional plan for Niagara Frontier, 26I

Citizens' Committee, 274

Planning Committee for Niagara Frontier, 283

Buildings, public, $85,2 \mathrm{I} 7$ private, 222

Bureau of Public Roads, 391, 392, 399, 402

Burnham, Daniel H., 52, 7I

Busch, Francis X., I72

Bush Terminal, r8I, 188

Busses, 165

Butler, Edward B., 72

Butler, Ovid M., 354

Buttenheim, Harold S., 312

Buttrick, P. L., 354

California, Mattoon Act, 3 ro

Cambridge, early layout, 27

Cameron, A. D., I35

Cameron, Jenks, 357, 368

Carbaugh, Harvey C., 2 II

Carrere, John M., 72

Carson, Harry Y., 82

Cedar Rapids, Robinson report, 70

Central Park, New York, 50

Characteristics of land, 324

legal and physical, 324

situations, 325

classification, 352

Charlestown, early layout, 3I

Cheney, Charles H., I52

Chicago, Ill., Plan report, $7 \mathrm{I}$ street widening, IO2

boulevards, II 7

planning projects, I48, I49

Water Street improvement, I60 rerouting of surface lines, 166 entrance by rail, 177,178 stations, I 80

blocks, 213

Regional Plan Association, 258

Sanitary District, 260

South Park Commission, 260

Citizens' body, 274

Plan Commission, 276
Cincinnati, Ohio, United City Planning Committee, 274

City Planning Commission, 277 Survey, 287

Circulation, 83

Citizens' Committees, 273

City Housing Corporation, 265

City Planners, National Conference, 65

Institute, 65

City Planning, history, 44

principles, $83 \mathrm{ff}$.

definition, 83

circulation, 84

parks and open spaces, 85

zoning, 85

sectors, 86

procedure, 273

commissions, 276

surveys, 285

cost, 299

significance, 306

Quarterly, 312

principles applicable to Nation, 320

City Planning Institute, organization, 65

Civic centers, $2 \mathrm{I} 7$

Clarke-McNary law, forests, 345 , $346,347,348$

Classification of traffic, IO4

uses of urban land, 235

land, 335

natural resources, 337

forests, 350

Colonization, 407

Colorado Springs, Colo., Robinson report, 70

Columbia, S. C., Kelsey-Guild report, 70

Comey, Arthur C., 89

Commission of Housing and $\mathrm{Re}-$ gional Planning, N. Y. State, $27 \mathrm{I}$

Commissions, Plan, 276

Zoning, 278

Art, 279

Park, 28r

Regional Plan, 282

Committee on Regional Plan of New York and its Environs, 256, 271

Communication, land, 384 
Communities, purpose of democratic, 4

Community planning, 5

Condemnation, excess, 305

Constitution of U. S. and Zoning, 244

Constitution of States and Zoning, 245

Corbett, Harvey Wiley, I43, I44, I 45

Cost of city planning, 297

specific projects, 301

special assessments, 302

pyramiding to be avoided, 306 economic considerations, 306

Council on National Parks, Forests and Wild Life, 359, 368, 369, 4 I 6

Country Club District, Kansas City, 34, 223, 262

County and State buildings and grounds, 4I I

County seats and State capitals, $4{ }^{2} 2$

Court decisions on Zoning, 245

Crawford, Andrew Wright, 8I, 248

Crops, lack of plan, 402 acres, 405

Crosby, Dick J., 8I

Cushman, Robert Eugene, 309

Cut-over areas and forest lands, 344

Dallas, Texas, Kessler report, 72

George B. Dealey, 8I, 274

Kessler Plan Association, 274

Davis, W. M., 285

Dealey, George B., 8I, 274

Delano, Frederic A., 72, 79, 8I, I 93, I94, 224 ff., 229, 230, 270, 295, 309

Democratic communities, purpose, 4

Denver, Colo., civic center, 219

Detroit, Mich., Master Plan report, 89

congestion; 150

Districts, zoning, use, height and area, 232, 233, 234

classification, 235

assessment, 305
Division of Building and Housing, U. S. Dept. of Commerce, 79, 222, 4I 5

Dodds; Harold W., 3I2

Doell, Charles E., $2 \mathbf{I I}$

Doolittle, Will O., 3I2

Downing, Andrew Jackson, 50, 68, I3I

Dunn, W. H., 72

Dwellings built in U. S., II

Early settlements, layouts, 27

Easements and setbacks, 307

Economic considerations, changing the map, 306

forests, $35^{2}$

Economists, need for, 68

Elgin, Ill., Bennett report, 7I

Eliot, Charles, 52

Eliot, Charles W., president Emeritus of Harvard University, 92

Ely, Richard T., 321, 322, 324, $325,326,328,329,336,340$, $354,383,408$

Encroachments on public streets, II 9

Engineers, co-operation, 47 municipal, 56

Entrances, thoroughfares, I 76 rail, 177

water, 185

bridges, I 90

air, 190

Excess condemnation, 305

Farm plans, early, 39

Federal Aid Roads, 386, 391, 392

Federal City, 35

centennial celebration, 52

Committee of the American Civic Association, 79

Federal Power Commission, 378, $379,380,381,383$

Federated Societies on Planning and Parks, 80

Ferries, I 70

Finley, John H., 329

Fisher, Carl G., 387

Fisher, E. M., 340

Fisher, Walter, Secretary of the Interior, 34, 8I, 386

Footways, II 7

Ford, Amelia C., 26 
Ford, Frederick L., $8 \mathrm{I}$

Ford, George B., 8I, 270, 295, 309

Forest lands and cut-over areas, 344

National, 348

classification, 350

Forest Preserves Cook County, I98

Forest Service, 346, 354

Fort Wayne, Ind., Robinson report, 70

Gale, Zona, 76, 8I

Gifford, Ward C., 340

Goodrich, Ernest P., 155, 156, I93, 195

Gordon, Lord Adam, 25, 3I

Grant, Ulysses S., President of the United States, 357

Grade crossings, I83

Grand Rapids, Mich., Brunner and Carrere report, 72

Graves, Henry S., 329, 354

Grazing in National Forests, $35 \mathrm{I}$ and ranches, 406

Gray, L. C., 322, 323, 408

Greeley, Horace, 385, 386, 400

Greeley, William B., Chief Forest

Service, 347, 35I, 354, 36I

Greenleaf, James L., 368

Greenwood, Ernest, I 55

Gries, John M., 82, 248

Groeniger, William C., 82

Haldeman, B. A., 98, II8

Hamlin, Chauncey J., 26I

Hanley, Thos. F., 82

Hansen, A. E., 82

Harding, Warren G., President of United States, 328

Harrisburg, $\mathrm{Pa}$., I 88

Hastings, Lewis M., 43

Hatt, William K., 82

Height districts, zoning, 232

Henry, George E., 312

Herrold, George H., 89, 94

Hibbard, Benjamin H., 315, 322

Hiett, Irving B., 8r, 248

Highways, permanence of, 3

early routes, local and main, 20, 22

arterial, main, 89, 104

entrances into cities, 170

park to park, 368
Highways, land communication, 384

Federal Aid, 386

Associations, 388

Bureau of Public Roads, 39r

State Systems, 392

Hoffman, Paul C., 155

Honolulu, Robinson report, 70

Hoover, Herbert, 82, 155, 248, 375, 377,383

Housing reform, $58 \mathrm{ff}$.

Housing Betterment, quarterly, 3 2

Howe, Oliver H., 28, 42

Hubbard, Henry V., 52, 55, 199, 2 IO, 312

Hulbert, A. B., 23

Hungerford, Edward, 400

Ihlder, John, 8I, I4I, I55, 248

Inland waterways, 375,376

Institute for Research in Land Economics and Public Utilities, 293

Journal, 312

organization, 329

scope, 340

Interior of blocks, use of, II4

Inventory, land, 327, 334

Irrigation, 382

James, Harlean, 42, 8r, 295, 309, 400,401

Jefferson, Thomas, 36

Jones, E. Lester, 295

Journal of Land and Public Utility Economics, 312

Kansas City, Country Club District, $34,223,262$

Dunn Park report, 72

park system and purchase, 3 IO

Kean, Evalina, 68

Kelsey, Harlan P., 70, 8I

Kessler, George, 70, 72

Kies, W. S., 329

Kimball, Theodora, 89, 90, $31 \mathrm{I}$

Knowles, Morris, 58, 8I, 248

La Crosse, Wis., Nolen report, 72

Lanham, Clifford, I35

Land Board proposed, 410 
Land characteristics, 324 classification, 335 natural resources, 337 communication, 384

Land Economic Survey, 33I

Land Inventory, 327, 334

Land Planning, 313,338

Land policies in layout, 15 national, $3 \mathbf{1} 3$

Land, relation to population, 7 resources, II uses, $317,323,349$

Land values and parks, 208, 209

Lands, public domain, 3I4 permanent public, 3I5 distribution public domain, 316 communication and public domain, 319

mineral and oil, 3ro

forest and cut-over, 344

Federal-owned, 409

Landscape architects, co-operation, 47

professional organization, 54, 55

Landscape Architecture, quarterly, $3 \mathrm{I} 2$

Landscape design, 48

Latrobe Journal, 26, 4I

Lay, Charles Downing, 42

Layout, early land policies and settlements, 15,27

Legal characteristics of land, 324

L'Enfant Plan for the Federal City, 36, 37, 38, 220

Leopold, Aldo, 368

Lewis, Harold M., 155,156

Lewis, Nelson P., 58, 8I, 9I, 93, I 22, I 35, I68, I 72, I 73, 248, 309, 3II

Lieber, Richard, 365, 368

Longview, Washington, 269

Los Angeles, Cal., streets, 102 congestion, $\mathrm{r}_{52}$

region, 25I, 258

Plan Commission, 277

Regional Plan Commission, 283

Louisville, Ky., Cherokee Park, I I 7

Lovejoy, P. S., 322, 327, 333, 334, $34 \mathrm{I}, 342,343$

Lowden, Frank O., 329

MacChesney, Nathan William, 329

MacDonald, Thomas H., 400
McFarland, J. Horace, 34, 75, 76, $77,81,135,136,210,211,248$, 368

McKim, Charles F., 52

McMillan, Senator from Michigan, 52

McNary-Woodruff bill, forests, 353

MacVeagh, Franklin, 7I

Madison, Wis., Nolen report, 72

Manning, Warren H., 42, 5I, 68, $108,322,367,368,371,375$, 377

Map-making agencies, 285, 286, 327

Maps, 285, 286, 306

Marketing and land planning, 402

Mariemont, Ohio, 268

Massachusetts Department of Public Welfare, 4I5

Massachusetts Division of Metropolitan Planning, 250, $27 \mathrm{I}$

Massachusetts State Parks, 362

Massachusetts Federation of Planning Boards, 4I5

Mather, Stephen T., 358

Mattoon Act, California, 310

Mead, Elwood, 383

Memphis, Tenn., traffic, I46

report, 157

Miami Conservancy District of Ohio, 260

Michigan Land Economic Survey, 331

Roscommon County, 335

significance, 339

Academy of Science, 340

Miller, Rudolph P., 82

Mineral and oil lands, 319

Mitchell, Hugh C., 295

Monticello, home of Jefferson, 36

Moody, Walter D., r 93

Moore, Charles, 53

Moorehouse, Edward W., 26, 322, 340,408

Mount Vernon, layout, 4I

Mulford, F. L., I31, I35

Mumford, Lewis, 68, 69

Nason, Wayne, 367, 368

National Association of Real Estate Boards, 330

National Capital Park and Planning Commission, 39, 28 I 
National Commission of Fine Arts, $53,221,223,280$

National Conference on City Planning, organized, 65

member Federated Societies, 80 Proceedings, 3I 2

National Conference on State Parks, 80, 365

National Conference on Street and Highway Safety, I54, I55, I60

National Housing Association, 64

National League for Civic Improvement, 74

National Monuments, definition, 359

National Municipal Review, monthly, $3 \mathrm{I} 2$

National Parks, 357, 358, 359, 378

National Park Service, 79, 358, 368

National Planning, $3 \mathrm{I} 3 \mathrm{ff}$.

National Real Estate Journal, 312

Navigation, 375

Nelson, Herbert U., 340

New England, early grants, I 7

New Hampshire farm group, 40

Newlin, J. A., 82

New Orleans, Regional Plan, 284

New York City, early layout, 32

Central Park, 50

tenements, $60 \mathrm{ff}$.

report of Improvement Commission, $7 \mathrm{I}$

Bronx Parkway, II7

traffic, I 38 , I39

freight carriers, 153

busses, . I65

Pennsylvania and Grand Central Stations, I80

skyscraper city hall, 2I9

zoning law, 239

Committee on Regional Plan, $256,259,283$

Art Commission, 280

New York State Parks, 363, 364

Niagara Frontier, Regional Plan, 26I, 283

Nichols, J. C., 8I, 9I, 263, 267, 27I

Nolen, John, 42, 7I, 8I, 89, I2I, I22, 135, 2 10, 268, 273, 295, $309,311,362,368,369$

Non-conforming uses, 234

Norton, Charles D., 72

Northwestern University, 329
Oakland, Cal., East Bay Municipal Utility District, 260

Ohio, State Parks, 363

Olmsted, Frederick Law, 51, 52

Olmsted, Frederick Law, Jr., 52, $71,72,81,89,90,146,152$, I55, 248, 267, 276, 286, 296, 302

Olmsted Bros., report to Park Board, Portland, Ore., 2 II

Open spaces-parks, 84, 196

Outdoor Recreation, President's Conference, I9, 80

Page, L. W., 23, 385, 400

Palos Verdes, Cal., 269

Park and Outdoor Art Association, the, 74

Park Commission Report of I90I to Senate, Washington, D. C., $52,53,68,70$

Parks and open spaces, 84,196

classification, 199

transportation, 201

playgrounds, 202

uses, 207

land values, 208, 209

purchases, 210

National, 357

State, 36I

Parks and Recreation, 312

Parks, Druid Hill, Cherokee and Golden Gate, II 7

Central, Druid Hill, Rock Creek and Golden Gate, 197

Boston Metropolitan System, I98

South Parks, Chicago, 200

Park-to-park highways, $368,37 \mathrm{I}$

Payne, John Barton, 320, 359, 365

Pattee, Sarah Lewis, 68

Peaslee, Horace W., 55

Pennsylvania, Department of Internal Affairs, 4I5

Peters, J. G., 4I6

Philadelphia, early layout, $3 \mathbf{I}, 48$ congestion and street widening, I 50

blocks, 213

Phillips, T. Glenn, I 55

Physical characteristics of land, 324

Piece-meal land planning, 313 
Pinel, Sidney, 155

Pittsburgh, traffic, I 46 Art Commission, 280

Plan Commissions, 276

Planning, community, 5

opportunity, I 2

history of city, $44 \mathrm{ff}$.

principles of city, $83 \mathrm{ff}$.

regional, $249 \mathrm{ff}$.

surveys, 285

cost of city, 299

significance, 306

National and State, 313 land, 338

Platting, 216

Playgrounds, 202

Pleasure roads and boulevards, II 7

Pomeroy, Hugh R., 270

Portland, Ore., Olmsted park report, 2 II

Art Commission, 280

Power resources, 319, 378

Population, growth of, 7,8 increase in urban and rural, to

President's National Conference on Outdoor Recreation, 80

Projects, cost of specific, 301 charged against general tax, 302 special assessments, 302

Public buildings and grounds, 85, 2 I7

State and county, 4 II

Public Conveyances, 163

Public domain, $3 \mathrm{I} 4$

distribution, 316

and communication, 319

Public lands, public domain, 314 permanent, $3 \mathrm{I} 5$

distribution of public domain, 3 I6

Federal-owned, 409

Private buildings, 222

Private lands, Federal agencies giving advice, 410

Procedure, city planning, 273

Purdy, Lawson, 8I, 295, 309

Purchase of parks, 210

Pyramiding costs, 306

Raleigh, N. C., Robinson report, 70

Rail, early routes, 25 entrances into cities, 177
Rail service for industriai sections, 188

Railways, 396

Rapid transit, $167 \mathrm{ff}$.

Real estate dealers, 66

National Association of R. E. Boards, 330

Reclamation towns, 34

Recreation areas, 356

in National parks, 357

in National forests, 360

rural, 366

Reed, Thomas H., 282

Regional planning, $249 \mathrm{ff}$.

theory, $25 \mathrm{I}$

zoning, 254

open spaces, 257

associations, 258

commissions, 282

Resources, land, II, 327

power, 3I9, 378

water, 373

Rhode Island, Metropolitan Park Commission, 26I

Richey, Emma, 68

Riis, Jacob, 63

Ripley, William Z., 398, 400

Roads, see highways

Roanoke, Va., Nolen report, $7 \mathrm{I}$

Robinson, Charles Mulford, 70, 89, I06, 3II

Rochester, Brunner-Olmsted-Arnold report, 72

Roland Park, Baltimore, 34, 223, 262

Roosevelt, Theodore, President of United States, 197

Roscommon County, Michigan, survey, 335

Rosenberry, M. B., 329

Routes of roads, local connections, 20

National highways, 388

State highways, 392

Rural recreation spaces, 366

Russell, Ernest J., 82

Russell Sage Foundation, 42

Committee on Regional Plan of N. Y., 259

Sage Foundation, 42, 259

St. Augustine, early layout, 3 I

Saint Gaudens, Augustus, 52 
Saint Louis, early layout, 48

Kessler report, 70

Civic Committee report, 7I congestion and street widening, I5I

bond issue, 274

Saint Paul, Minn., Regional Plan Commission, 284

San Francisco, topography, 33 streets, IO2

Golden Gate Park, II 7

Civic Center, 2 I 9

San Jose, Cal., Robinson report, 70

Santa Barbara, Cal., Robinson report, 70

Satellite towns, 268

Sauer, C. I., 33I

Savannah, Ga., early layout, 3 I

Seattle, Wash., Bogue report, 72, I 88, I 89

Setback regulations, 243

and easements, 307

Shaw, Albert, 329

Shine, Mary L., 383, 408

Shopping centers for subdivisions, 264

Shurtleff, Arthus, 40, 42

Shurtleff, Flavel, 65, 302, 309, 31 2

Skyscrapers, 224

Smith, Ernest N., 400

Smith, George Otis, 23

Smith, Herbert A., 344, 354

Snyder, George Duncan, I 72

Springfield, Mass., civic center, 2 I9, 220

State and county buildings and grounds, 4I I

State Capitals and county seats, 412

State enabling acts, 284, 4I $3,4 \mathrm{r} 4$

State highway systems, 392 arrangement, 393

State Parks and reservations, 36I ff.

classification, 365

facilities, 366

State Planning, 313

Stein, Clarence S., 54

Streets, systems, 96

new streets, 97

radial growth, 98

arterial highways, 99

major traffic streets, 108 minor streets, I09

alleys and lanes, Ir 3

footways, II 7

pleasure roads, II 7

width and arrangement, Irg

encroachments, II9

arrangement, 124

business streets, 125

residence streets, 125

furnishing, 126

markings, 130

trees, 130

traffic, 138

transit, I63

Subdivisions, 262

sh sping centers, 264

Sunnyside, L. I., 265

Surveys, National system, 18 city planning, 285

personnel, 292

land, 327

Michigan Land Economic, 33r, 404

Swan, Herbert S., 8I, I26, I35, 248

Taft, William Howard, President of United States, 53, 8I, 368

Toledo, Ohio, Lucus Co. Planning Commission, 260, 284

Taxation, general, 302

special assessments, 302 .

Taylor, Graham Romeyn, 269, $27 \mathrm{I}$

Taylor, Henry C., 329, 408

Technical Advice, II3

Technical Advisory Corporation, 287

Telegraph and telephone wires, 399

Terminals, Bush, I8I

Time element in developing land, 267

Townsend, Charles R., 400

Traffic, classification, $\mathrm{IO}_{4}$

major streets, 108

congestion, $\mathrm{I}_{3} 8$

regulation, $\mathbf{I} 40$

segregation, I42

widening, 143

two- and three-level, 143

decentralization, I45

remedies applied, I 46

freight carriers, I 52

on State and National highways, 395 
Transit and the street system, I63 Transport, $\mathrm{I} 76 \mathrm{ff}$.

Turner, Daniel L., 168

United States, increase in area, ro, 313

public domain, $3 \mathrm{I} 4$

United States Forest Service, 346, 354

United States Housing Corporation, 65, II 5, 118, 293, 294

Unwin, Raymond, 145,156

Use districts, zoning, 232

Uses of land, $317,323,349$

Utica, N. Y., Olmsted report, 7 I

Vaux, Calvert, $5 \mathbf{I}$

Veiller, Lawrence, 64, 81, 248, 312

Virginia, early grants, 16

Wacker, Charles H., 72, 155, 193

Wacker's Manual, 72

Wadsworth, George R., I8I, I93

Wagner, Samuel R., I93

Ward. Beatrice M., 365

Washington, D. C., 35, 50, 70

arterial highways, ror

streets, 125

ellipse and street trees, I3I

Union Station, I8I

blocks, 215

Capitol and public buildings, 220

Suburban Sanitary District, 260

National Commission of Fine Arts, 280

National Capital Park and Planning Commission, 280

Washington, George, 36

Waterfronts, I87

Waterloo, Ia., Robinson report, 70

Water power, 378

Water resources of United States, 373

navigation, 375

power, 378

irrigation, 382

Waterways, early routes, 25

inland, 375,376
Waugh, Frank A., 21, 34, 68, 8I, 400,401

Weeks, J. Borton, 155

Weeks law, forests, 346

Wehrwein, George S., 383, 408

Wharves, 188

Wheelwright, Robert, 55

Whipple, George C., 82

Whitten, Robert, 254, $27 \mathrm{I}$

Williams, Frank B., 89, 90, 96, 248, 3 II

Williamsburg, early layout, 29

Wilson, Margaret Woodrow, 8I

Wilson, Walter H., 72

Wilson, Woodrow, President of United States, 320

Wires, 126, 399

Wisconsin, State Parks, 362

Wisconsin, University of, 329

Wood, Mrs. Edith Elmer, 60

Wood, Fred J., 23

Woolson, Ira H., 82

Worcester, Joseph R., 82

Worcester, Mass., survey, 287

World's Fair and architecture, 45

example, 2 I 7

Y. M. C. A. Schools, 330

Zoning, $85 \mathrm{ff}$.

comprehensive planning, 23I

use districts, 232, 234

height districts, 232

area districts, 233

non-conforming uses, 234

classification, 235

blighted districts, 235

neighborhood stability, 237

danger in ready-made law, 238

New York law, 239

setbacks, 243

billboards, 244

Constitution, 244

court decisions, 245

Commissions, 278

Boards of Appeal, 279 


. 





